OAK RIDGE

NATIONAL LABORATORY

MANAGED BY UT-BATTELLE

FOR THE DEPARTMENT OF ENERGY

\title{
Guide to Combined Heat and Power Systems for Boiler Owners and Operators
}

\author{
C. B. Oland
}
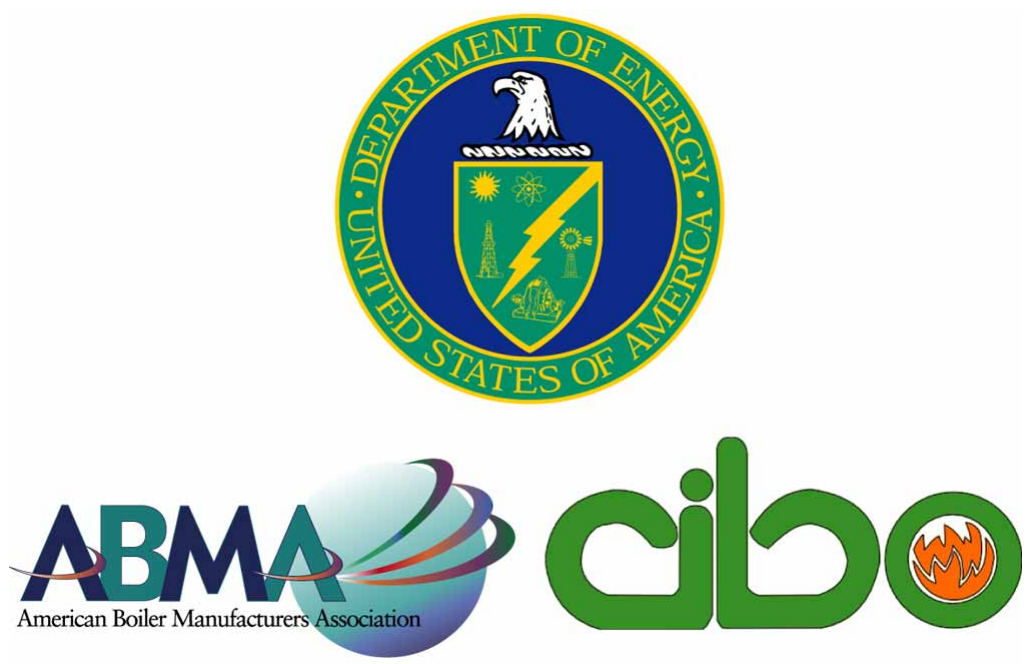

UT-BATTELLE 


\section{DOCUMENT AVAILABILITY}

Reports produced after January 1,1996, are generally available free via the U.S. Department of Energy (DOE) Information Bridge:

Web site: http://www.osti.gov/bridge

Reports produced before January 1,1996, may be purchased by members of the public from the following source:

National Technical Information Service

5285 Port Royal Road

Springfield, VA 22161

Telephone: 703-605-6000 (1-800-553-6847)

TDD: 703-487-4639

Fax: 703-605-6900

E-mail: info@ntis.fedworld.gov

Web site: http://www.ntis.gov/support/ordernowabout.htm

Reports are available to DOE employees, DOE contractors, Energy Technology Data Exchange (ETDE) representatives, and International Nuclear Information System (INIS) representatives from the following source:

Office of Scientific and Technical Information

P.O. Box 62

Oak Ridge, TN 37831

Telephone: 865-576-8401

Fax: 865-576-5728

E-mail: reports@adonis.osti.gov

Web site: http://www.osti.gov/contact.html

This report was prepared as an account of work sponsored by an agency of the United States Government. Neither the United States government nor any agency thereof, nor any of their employees, makes any warranty, express or implied, or assumes any legal liability or responsibility for the accuracy, completeness, or usefulness of any information, apparatus, product, or process disclosed, or represents that its use would not infringe privately owned rights. Reference herein to any specific commercial product, process, or service by trade name, trademark, manufacturer, or otherwise, does not necessarily constitute or imply its endorsement, recommendation, or favoring by the United States Government or any agency thereof. The views and opinions of authors expressed herein do not necessarily state or reflect those of the United States Government or any agency thereof. 


\title{
GUIDE TO COMBINED HEAT AND POWER SYSTEMS FOR BOILER OWNERS AND OPERATORS
}

\author{
C. B. Oland
}

July 30, 2004

\author{
Prepared for the \\ U.S. Department of Energy \\ Industrial Technologies Program
}

\author{
Prepared by \\ OAK RIDGE NATIONAL LABORATORY \\ Oak Ridge, Tennessee 37831 \\ managed by \\ UT-BATTELLE, LLC \\ for the \\ U.S. DEPARTMENT OF ENERGY \\ under contract DE-AC05-00OR22725
}




\section{CONTENTS}

Page

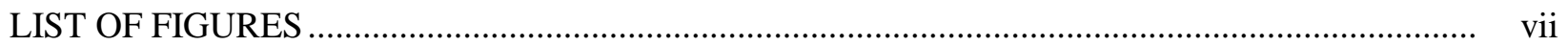

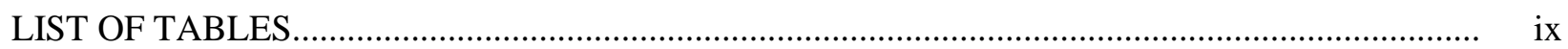

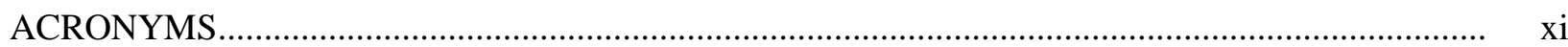

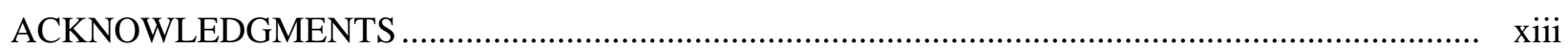

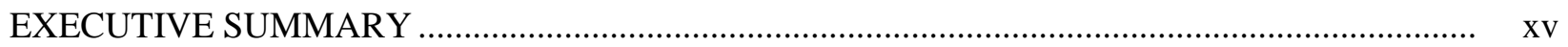

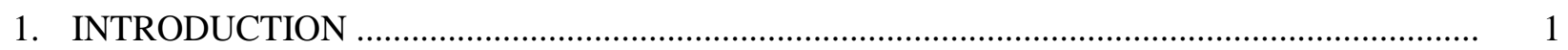

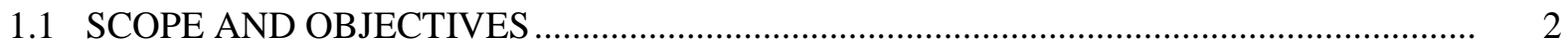

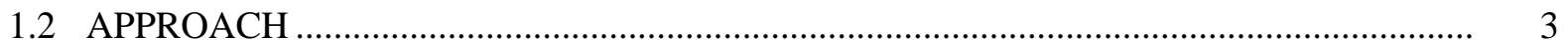

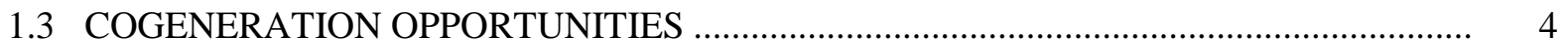

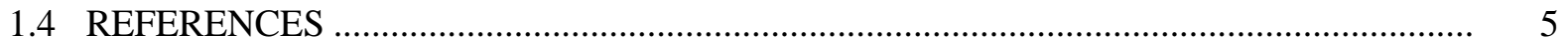

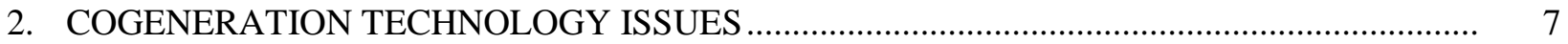

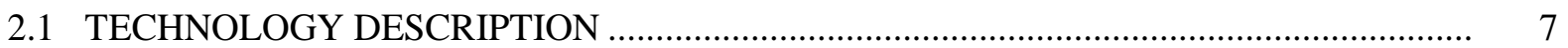

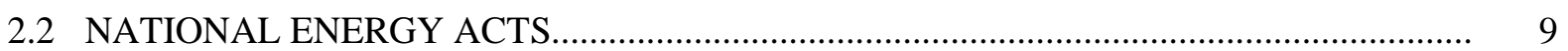

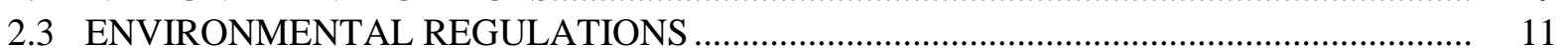

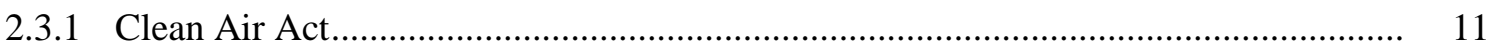

2.3.1.1 National Ambient Air Quality Standards ............................................. 14

2.3.1.2 New Source Performance Standards ....................................................... 14

2.3.1.3 National Emission Standards for HAPs .................................................. 16

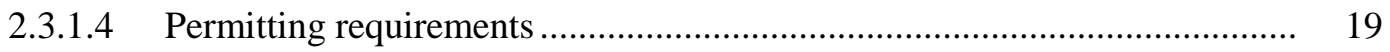

2.3.1.5 State permitting programs ..................................................................... 23

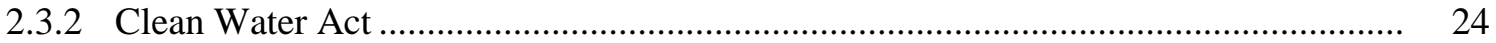

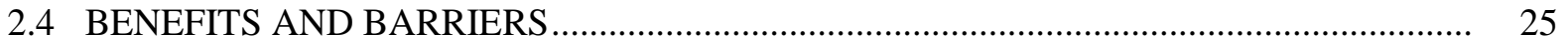

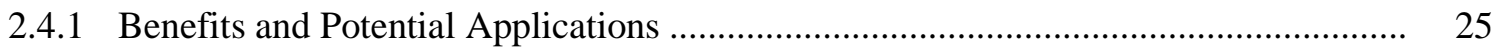

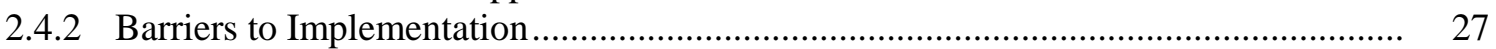

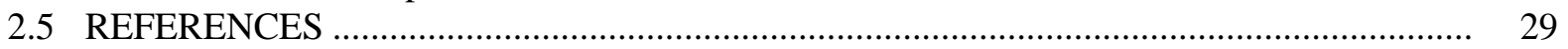

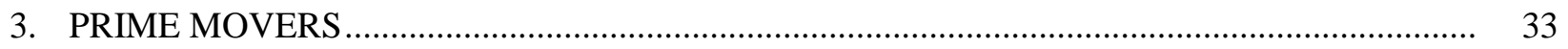

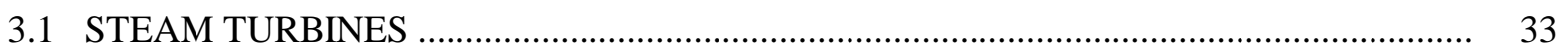

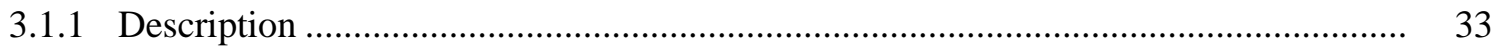

3.1.2 Design and Performance Characteristics ......................................................... 36

3.1.2.1 Efficiency ............................................................................... 39

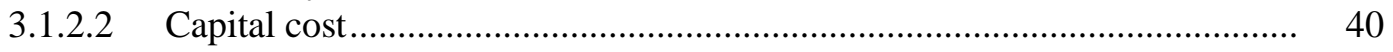

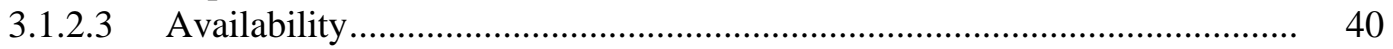

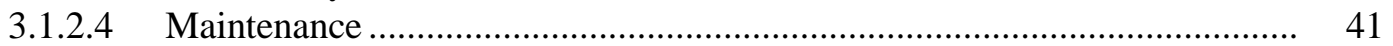

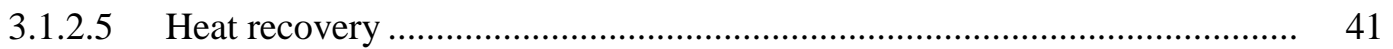

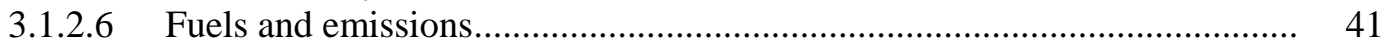

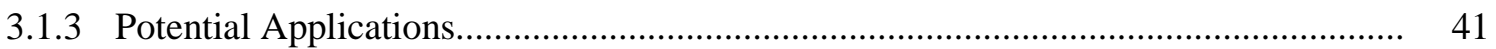

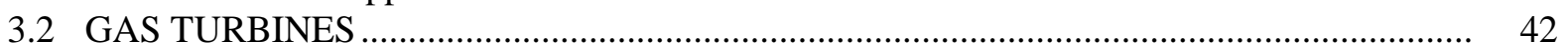

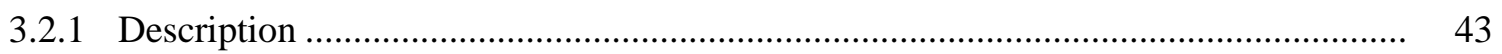

3.2.2 Design and Performance Characteristics ........................................................... 44

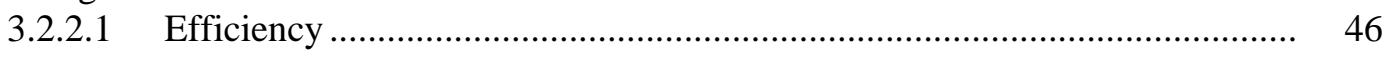

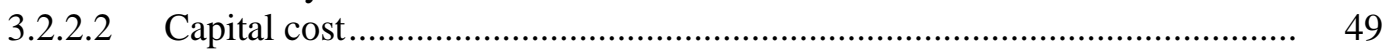

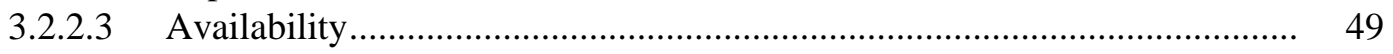

3.2.2.4 Maintenance ................................................................................ 49

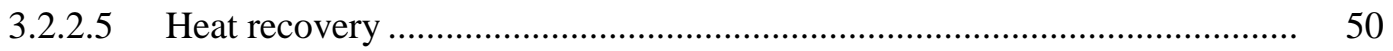

3.2.2.6 Fuels and emissions.......................................................................... 50 
3.2.3 Potential Applications................................................................................. 51

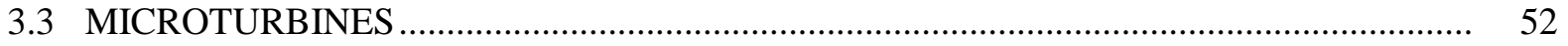

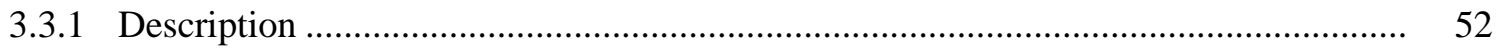

3.3.2 Design and Performance Characteristics ................................................................. 52

3.3.2.1 Efficiency .................................................................................... 54

3.3.2.2 Capital cost ................................................................................. 54

3.3.2.3 Availability ................................................................................ 54

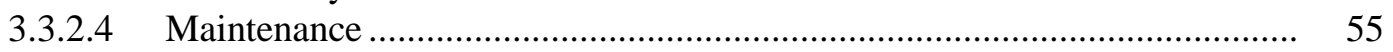

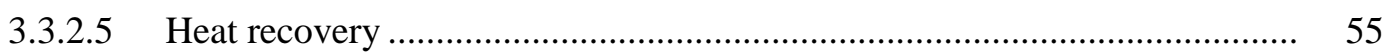

3.3.2.6 Fuels and emissions........................................................................... $\quad 55$

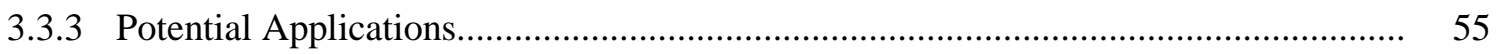

3.4 RECIPROCATING INTERNAL COMBUSTION ENGINES ............................................ 56

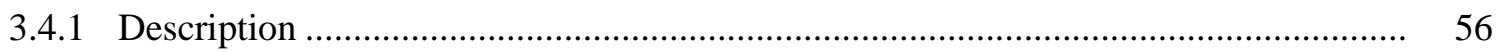

3.4.2 Design and Performance Characteristics ………………………………………….. 56

3.4.2.1 Efficiency ................................................................................ 57

3.4.2.2 Capital cost....................................................................................... 60

3.4.2.3 Availability.................................................................................... 60

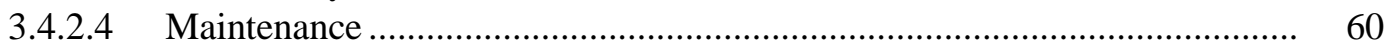

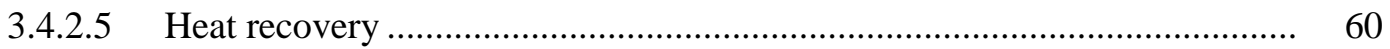

3.4.2.6 Fuels and emissions....................................................................... 61

3.4.3 Potential Applications......................................................................................... 61

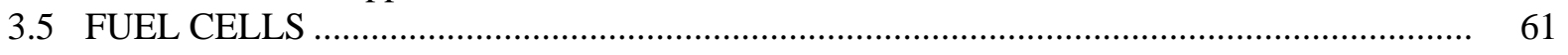

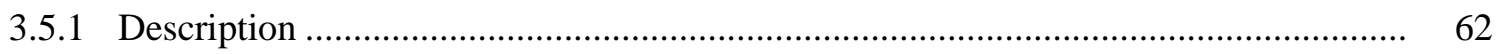

3.5.2 Design and Performance Characteristics ................................................................. 62

3.5.2.1 Efficiency ……………………………………………………..... 63

3.5.2.2 Capital cost ................................................................................ 64

3.5.2.3 Availability.................................................................................. 65

3.5.2.4 Maintenance …………………………………………………….... 65

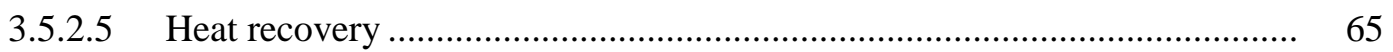

3.5.2.6 Fuels and emissions............................................................................. $\quad 65$

3.5.3 Potential Applications......................................................................................... 65

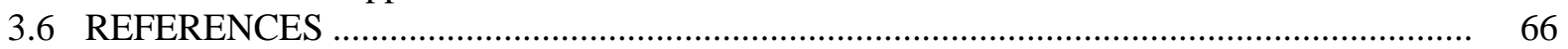

4. HEAT-RECOVERY EQUIPMENT …………………….............................................. 71

4.1 UNFIRED UNITS ........................................................................................... 71

4.1.1 Unfired Heat-Recovery Steam Generators ................................................................ 74

4.1.2 Heat-Recovery Mufflers ………………………………………………………. 75

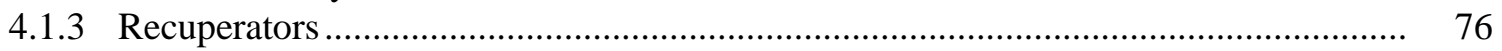

4.1.4 Regenerators ……………………………………………………………. 77

4.1.5 Ebullient Cooling Systems ....…………………………………………………. 77

4.1.6 Forced Circulation Cooling Systems ........................................................................ 77

4.1.7 Aftercoolers .................................................................................................. 77

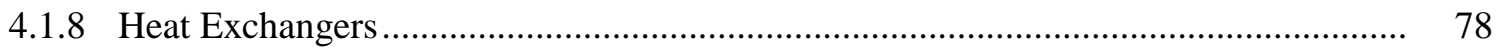

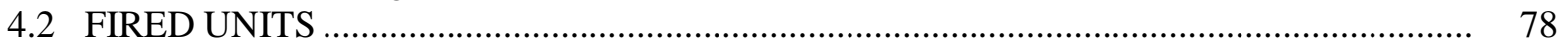

4.2.1 Supplementary Fired Heat-Recovery Steam Generators ......................................... 78

4.2.2 Industrial, Commercial, and Institutional Boilers.................................................... 84

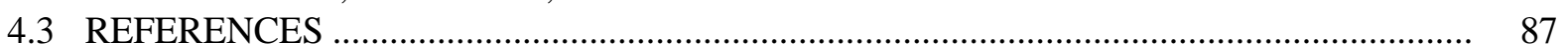

5. ELECTRIC POWER GENERATION …………………....................................................... 91

5.1 ELECTRICAL GENERATORS ............................................................................ 91

5.1.1 Synchronous Generators ..................................................................................... 92 


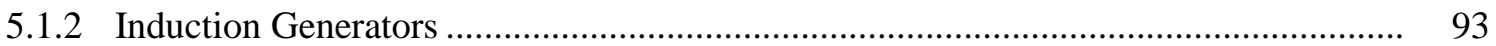

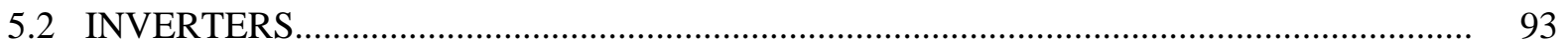

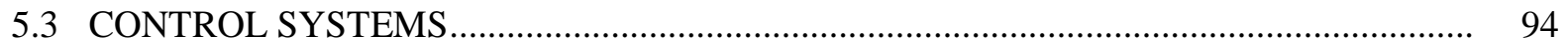

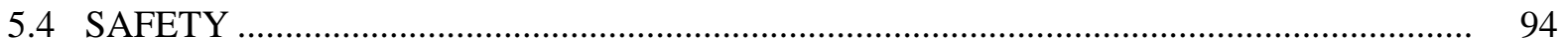

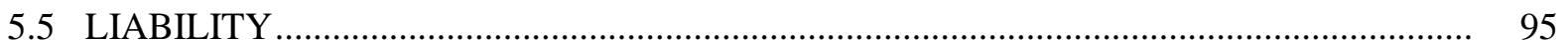

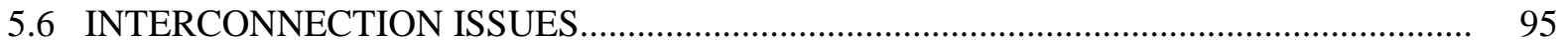

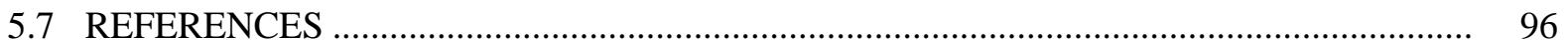

6. COOLING EQUIPMENT AND ROTATING MACHINERY ........................................... 97

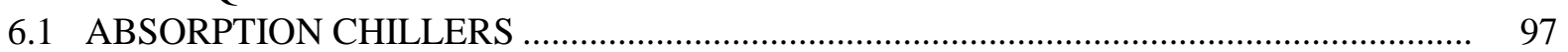

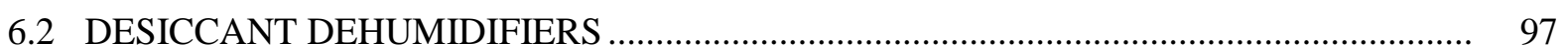

6.3 ROTATING MACHINERY ........................................................................... 98

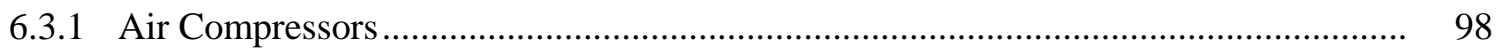

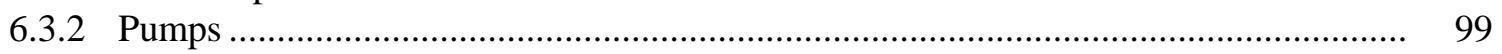

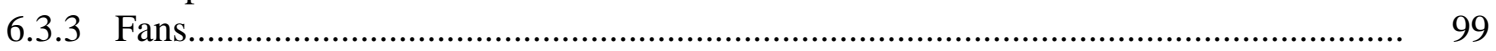

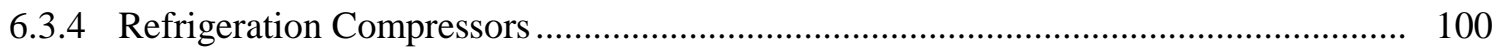

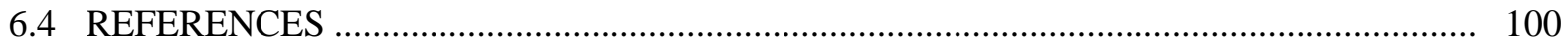

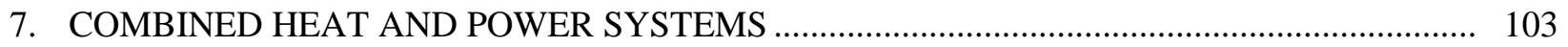

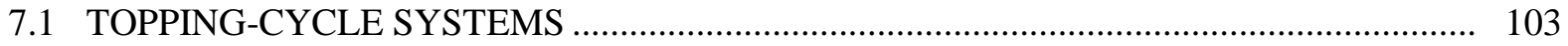

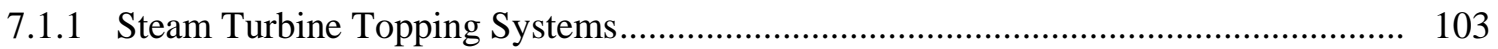

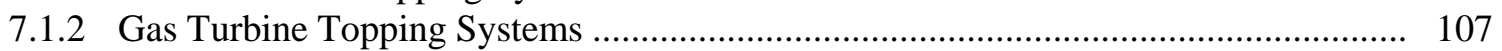

7.1.2.1 Open-cycle gas turbine topping systems ............................................. 108

7.1.2.2 Closed-cycle gas turbine topping systems......................................... 110

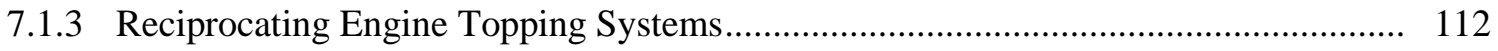

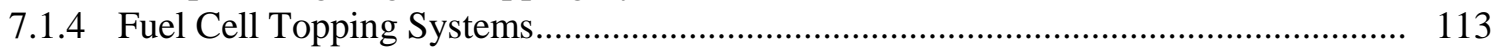

7.1.5 Microturbine Topping Systems ................................................................... 114

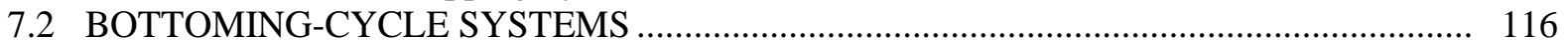

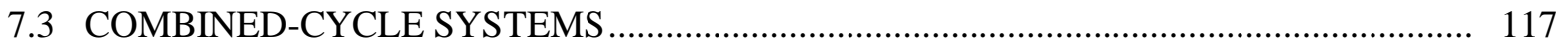

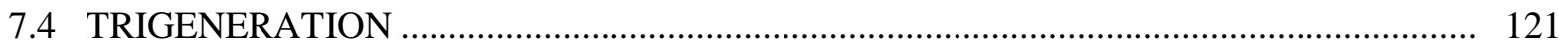

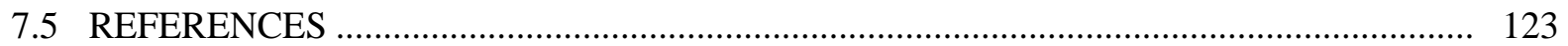

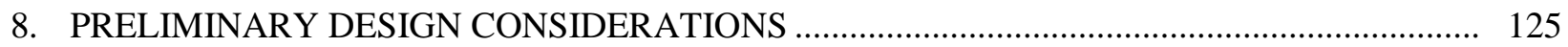

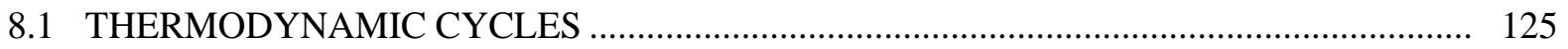

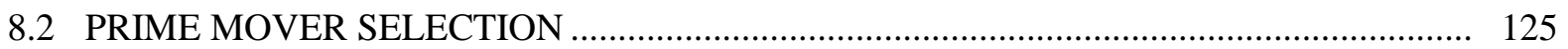

8.3 FUEL AND EMISSION CONTROL ISSUES ........................................................... 127

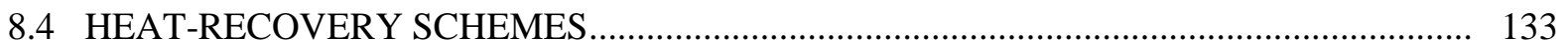

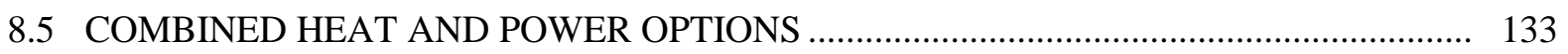

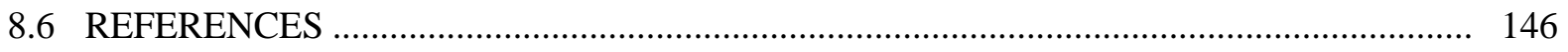

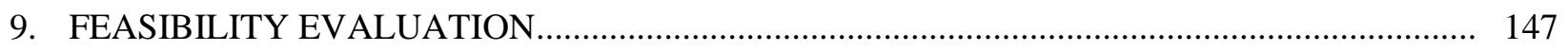

9.1 EVALUATING COGENERATION POTENTIAL _.................................................... 149

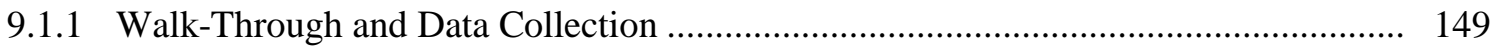

9.1.1.1 Energy savings opportunities ....................................................... 151

9.1.1.2 Preliminary screening......................................................................... 151

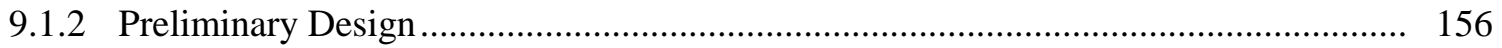

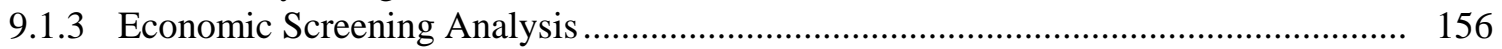

9.1.4 Health, Safety, and Environmental Issues ......................................................... 158

9.1.4.1 Noise and vibration ..................................................................... 158

9.1.4.2 Engineered and administrative controls .......................................... 158

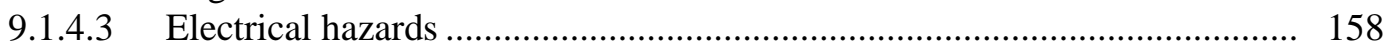

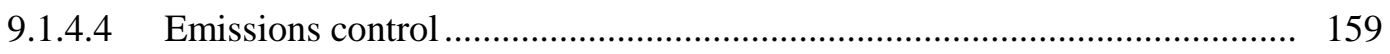

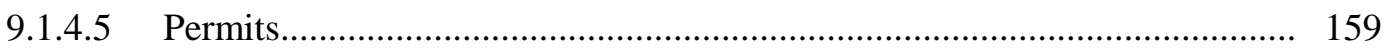




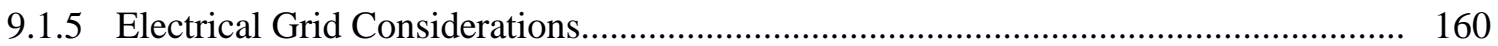

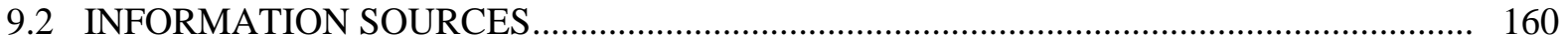

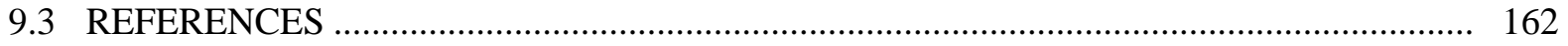

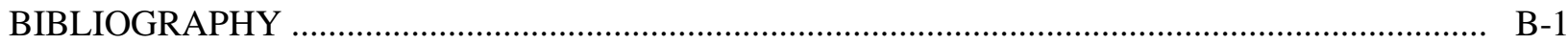

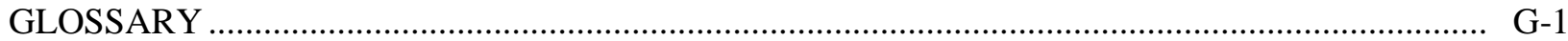




\section{LIST OF FIGURES}

ES.1 Format for presenting CHP systems options ….........................................................

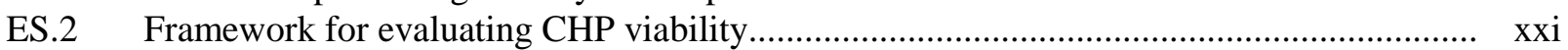

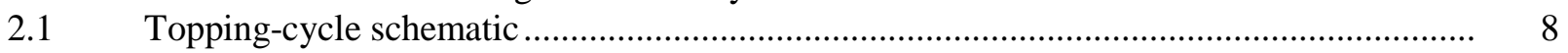

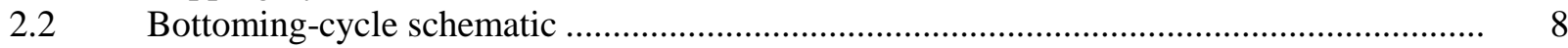

2.3 Criteria for assessing economic viability potential of cogeneration technology .................. 9

3.1 Noncondensing or back-pressure steam turbine configurations for CHP applications ........ 37

3.2 Extraction-condensing steam turbine configuration for CHP applications ....................... 37

3.3 Back-pressure steam turbine used as a pressure-reducing valve ..................................... 42

3.4 Open-cycle gas turbine configurations for CHP applications............................................. 44

3.5 Closed-cycle gas turbine configurations for CHP applications ........................................ 45

3.6 Single-shaft microturbine with high-speed generator for CHP applications ...................... 53

3.7 Two-shaft microturbine with conventional generator for CHP applications...................... 53

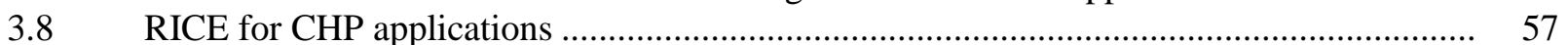

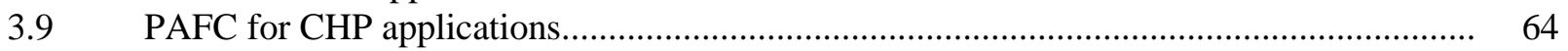

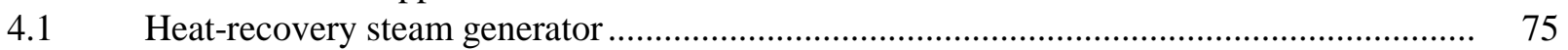

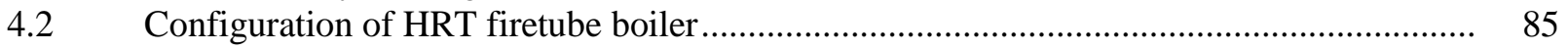

4.3 Configuration of Scotch package firetube boiler ..................................................... 85

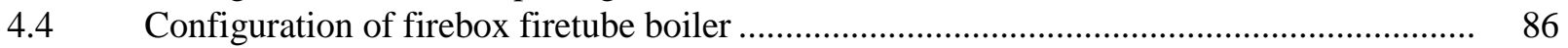

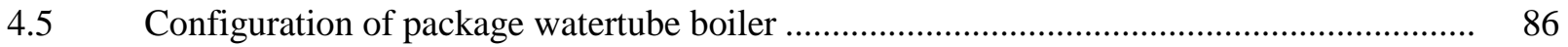

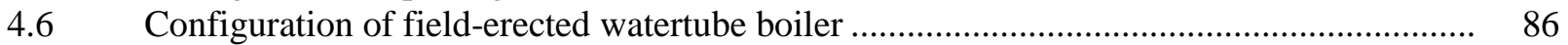

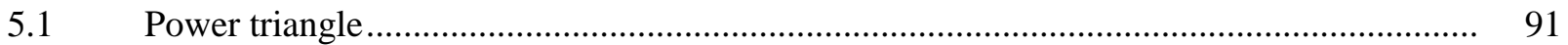

5.2 Phase difference between current and voltage caused by reactive load ............................ 92

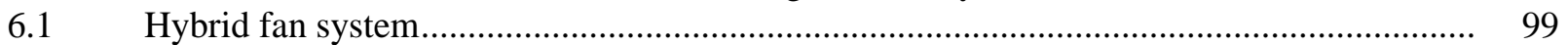

6.2 Dual-service reciprocating engine applications .......................................................... 100

7.1 Configuration of a steam turbine topping-cycle system used in a conventional power plant for electric power production............................................................................ 105

7.2 General configuration of a steam turbine topping-cycle CHP system............................. 106

7.3 Configuration of a back-pressure steam turbine topping-cycle CHP system for ICI boiler applications....................................................................................... 106

7.4 Configuration of an extraction-condensing steam turbine topping-cycle CHP system for ICI boiler applications......................................................................................... 107

7.5 Configuration of an open-cycle gas turbine topping-cycle CHP system (without recuperator) for ICI boiler applications ..................................................................... 108

7.6 Configuration of an open-cycle gas turbine topping-cycle CHP system (with recuperator)

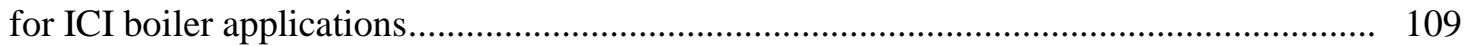

7.7 Configuration of a closed-cycle gas turbine topping-cycle CHP system (without regenerator) for ICI boiler applications

7.8 Configuration of a closed-cycle regenerative gas turbine topping-cycle CHP system (with regenerator) for ICI boiler applications .............................................................. 111

7.9 Configuration of a reciprocating engine topping-cycle CHP system for ICI boiler applications....

7.10 Configuration of a fuel cell topping-cycle CHP system for ICI boiler applications............ 114

7.11 Configuration of a microturbine topping-cycle CHP system (with conventional generator) for ICI boiler applications 
7.12 Configuration of a microturbine topping-cycle CHP system (with high-speed generator)

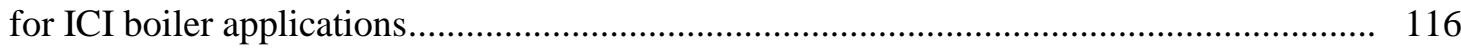

7.13 Configuration of a bottoming-cycle CHP system for ICI boiler applications .................... 117

7.14 Configuration of a combined-cycle CHP system (with feedwater preheat) for ICI

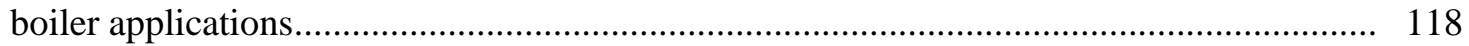

7.15 Configuration of a combined-cycle CHP system (with exhaust gas heat recovery) for ICI boiler applications........................................................................................ 119

7.16 Configuration of a combined-cycle CHP system (with recuperator) for ICI boiler

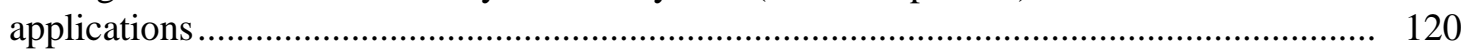

7.17 Configuration of a trigeneration system for ICI boiler applications ............................... 122

7.18 Alternative configuration of a trigeneration system for ICI boiler applications.................. 123

8.1 Back-pressure steam turbine topping-cycle CHP system options ................................... 134

8.2 Extraction-condensing steam turbine topping-cycle CHP system options ......................... 135

8.3 Open-cycle gas turbine topping-cycle CHP system (without recuperator) options.............. 136

8.4 Open-cycle gas turbine topping-cycle CHP system (with recuperator) options ................. 137

8.5 Microturbine topping-cycle CHP system (with conventional generator) options ................ 138

8.6 Microturbine topping-cycle CHP system (with high-speed generator) options .................. 139

8.7 Reciprocating engine topping-cycle CHP system options ....................................... 140

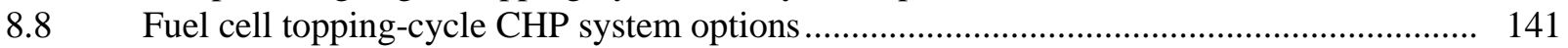

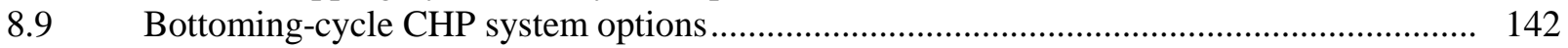

8.10 Combined-cycle CHP system options ................................................................ 143

8.11 Combined-cycle CHP system (with feedwater heating) options .................................... 144

8.12 Trigeneration CHP system options ........................................................................ 145

9.1 Framework for evaluating the viability of a CHP project......................................... 148

9.2 Example data collection sheet .............................................................................. 150 


\section{LIST OF TABLES}

Table

Page

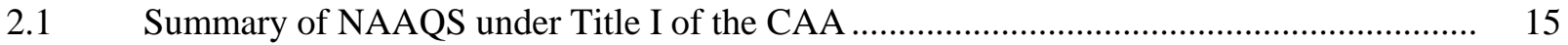

2.2 Standards of performance for new stationary steam generating sources ........................... 16

2.3 MACT standards for steam generating source categories ........................................... 17

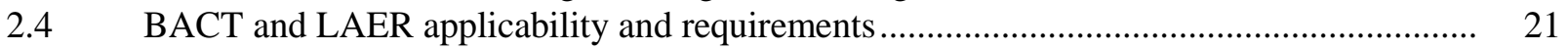

3.1 Characteristics of prime movers for CHP applications ….............................................. 34

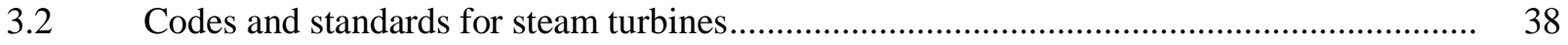

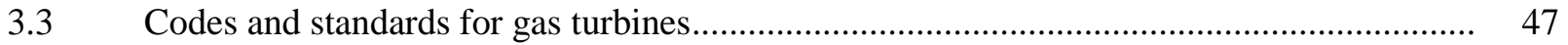

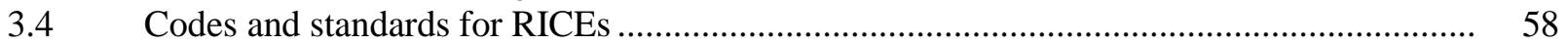

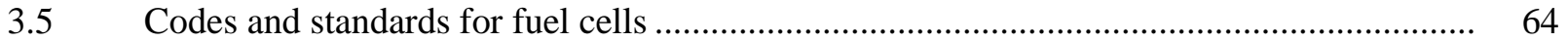

4.1 Codes and standards for heat-recovery equipment ......................................................

4.2 Options for using HRSGs and ICI boilers to recover waste heat .................................... 79

4.3 Fuels commonly burned to generate hot water or steam ................................................. 80

4.4 Techniques for controlling emissions before combustion ............................................ 81

4.5 Techniques for controlling emissions during combustion ......................................... 81

4.6 Techniques for controlling emissions after combustion ...................................................

7.1 Typical CHP system performance characteristics ..................................................... 104

8.1 Factors to consider in choosing an appropriate thermodynamic cycle ............................... 126

8.2 Simple payback in years for natural-gas-powered CHP system with installation costs of $\$ 500 / \mathrm{kW}$

8.3 Simple payback in years for natural-gas-powered CHP system with installation costs of $\$ 2,000 / \mathrm{kW}$

8.4 Simple payback in years for oil-powered CHP system with installation costs of $\$ 500 / \mathrm{kW}$

8.5 Simple payback in years for oil-powered CHP system with installation costs of $\$ 2,000 / \mathrm{kW}$

9.1 Software for identifying energy savings opportunities ............................................. 152

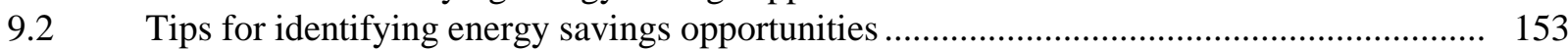

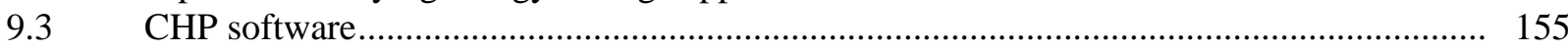

9.4 Websites with information about cogeneration technology ........................................ 161 


\section{ACRONYMS}

\begin{tabular}{|c|c|}
\hline $\begin{array}{l}\text { ABMA } \\
\text { ac }\end{array}$ & $\begin{array}{l}\text { American Boiler Manufacturers Association } \\
\text { alternating current }\end{array}$ \\
\hline AFC & alkaline fuel cell \\
\hline ANSI & American National Standards Institute \\
\hline API & American Petroleum Institute \\
\hline AQRV & Air Quality Related Values \\
\hline ASHRAE & American Society of Heating, Refrigerating and Air-Conditioning Engineers \\
\hline ASME & American Society of Mechanical Engineers \\
\hline ASTM & American Society for Testing and Materials \\
\hline BACT & Best Available Control Technology \\
\hline BCHP & building cooling, heating, and power \\
\hline $\mathrm{BF}$ & bias firing \\
\hline BOOS & burners out of service \\
\hline BT & burner tuning \\
\hline Btu & British thermal unit \\
\hline CAA & Clean Air Act \\
\hline CAAA & Clean Air Act Amendments \\
\hline $\mathrm{CaCl}_{2}$ & calcium chloride \\
\hline $\mathrm{CCHP}$ & combined cooling, heating, and power \\
\hline CFR & Code of Federal Regulations \\
\hline $\mathrm{CHP}$ & combined heat and power \\
\hline CHPB & cooling, heating, and power for buildings \\
\hline CI & compression ignition engine \\
\hline CIBO & Council of Industrial Boiler Owners \\
\hline $\mathrm{CO}$ & carbon monoxide \\
\hline $\mathrm{CO}_{2}$ & carbon dioxide \\
\hline CWA & Clean Water Act \\
\hline $\mathrm{dc}$ & direct current \\
\hline $\mathrm{DE}$ & distributetd energy \\
\hline DEER & Distributed Energy and Electric Reliability \\
\hline DER & distributed energy resources \\
\hline DOE & U.S. Department of Energy \\
\hline $\mathrm{E} / \mathrm{S}$ & electricity-to-steam ratio (kWh/MMBtu) \\
\hline EPA & U.S. Environmental Protection Agency \\
\hline EPACT & Energy Policy Act \\
\hline ESFF & electrostatically stimulated fabric filter \\
\hline ESP & electrostatic precipitator \\
\hline EWG & Exempt Wholesale Generator \\
\hline FBC & fluidized-bed combustion \\
\hline FEMP & Federal Energy Management Program \\
\hline FERC & Federal Energy Regulatory Commission \\
\hline FGD & flue-gas desulfurization \\
\hline FGR & flue gas recirculation \\
\hline FIR & fuel-induced recirculation and forced-internal recirculation \\
\hline FR & Federal Register \\
\hline GW & gigawatt \\
\hline HAP & hazardous air pollutant \\
\hline
\end{tabular}




\begin{tabular}{|c|c|}
\hline $\mathrm{HHV}$ & higher heating value \\
\hline HRSG & heat-recovery steam generator \\
\hline HRT & horizontal return tubular \\
\hline HVAC & heating, ventilating, and air conditioning \\
\hline $\mathrm{Hz}$ & Hertz \\
\hline ICI & industrial/commercial/institutional \\
\hline IEEE & Institute of Electrical and Electronic Engineers \\
\hline IES & integrated energy systems \\
\hline IRR & internal rate of return \\
\hline ISO & International Organization for Standardization \\
\hline ITP & Industrial Technologies Program \\
\hline $\mathrm{kVA}$ & kilovolt-amps \\
\hline kVAR & reactive kilovolt-amps \\
\hline $\mathrm{kW}$ & kilowatt \\
\hline $\mathrm{kWh}$ & kilowatt hour \\
\hline LAER & Lowest Achievable Emission Rate \\
\hline LEA & low excess air \\
\hline LHV & lower heating value \\
\hline $\mathrm{LiBr}$ & lithium bromide \\
\hline $\mathrm{LiCl}$ & lithium chloride \\
\hline LNB & low- $\mathrm{NO}_{\mathrm{X}}$ burner \\
\hline LP & liquefied petroleum \\
\hline MACT & Maximum Achievable Control Technology \\
\hline MCA & Midwest Cogeneration Association \\
\hline MCFC & molten carbonate fuel cell \\
\hline MMBtu & million Btu \\
\hline MSW & municipal solid waste \\
\hline MW & megawatt \\
\hline $\mathrm{N}_{2}$ & nitrogen \\
\hline NAA & nonattainment area \\
\hline NAAQS & National Ambient Air Quality Standards \\
\hline NB & National Board of Boiler and Pressure Vessel Inspectors \\
\hline NEMA & National Electrical Manufacturers Association \\
\hline NESHAP & National Emissions Standards for Hazardous Air Pollutant \\
\hline NFPA & National Fire Protection Association \\
\hline NGR & natural gas reburning \\
\hline $\mathrm{NO}_{2}$ & nitrogen dioxide \\
\hline $\mathrm{NO}_{\mathrm{x}}$ & nitrogen oxides \\
\hline NPDES & National Pollutant Discharge Elimination System \\
\hline NPV & net present value \\
\hline NSPS & $\begin{array}{l}\text { New Source Performance Standards or Standards of Performance } \\
\text { for New Stationary Sources }\end{array}$ \\
\hline NSR & New Source Review \\
\hline NYSERDA & New York State Energy Research and Development Authority \\
\hline $\mathrm{O}_{3}$ & ozone \\
\hline OFA & overfire air \\
\hline ORNL & Oak Ridge National Laboratory \\
\hline OSHA & Occupational Safety and Health Administration \\
\hline OT & oxygen trim \\
\hline
\end{tabular}




\begin{tabular}{|c|c|}
\hline OTR & Ozone Transport Region \\
\hline PAFC & phosphoric acid fuel cell \\
\hline PAL & plantwide applicability limitation \\
\hline $\mathrm{Pb}$ & lead \\
\hline PCP & pollution control project \\
\hline PEMFC & proton exchange membrane fuel cell \\
\hline PHAST & Process Heating Assessment and Survey Tool \\
\hline PM & particulate matter \\
\hline ppmV & parts per million by volume \\
\hline PSAT & Pumping System Assessment Tool \\
\hline PSD & prevention of significant deterioration \\
\hline PTE & potential to emit \\
\hline PUHCA & Public Utility Holding Company Act \\
\hline PURPA & Public Utility Regulatory Policies Act \\
\hline QF & qualified facility \\
\hline RAP & reducing air preheat \\
\hline $\mathrm{RDF}$ & refuse-derived fuel \\
\hline RICE & reciprocating internal combustion engine \\
\hline $\mathrm{rpm}$ & revolutions per minute \\
\hline SCA & staged combustion air \\
\hline $\operatorname{scf}$ & standard cubic foot \\
\hline SCR & selective catalytic reduction \\
\hline SI & spark ignition engine or steam injection \\
\hline SIC & Standard Industrial Classification \\
\hline SIP & State Implementation Plan \\
\hline SNCR & selective noncatalytic reduction \\
\hline $\mathrm{SO}_{2}$ & sulfur dioxide \\
\hline SOFC & solid oxide fuel cell \\
\hline $\mathrm{SO}_{\mathrm{x}}$ & sulfur oxides \\
\hline SPP & small power producer \\
\hline SSAT & Steam System Assessment Tool \\
\hline TDF & tire-derived fuel \\
\hline TWC & three-way catalyst \\
\hline UL & Underwriters Laboratories \\
\hline USCHPA & U.S. Combined Heat and Power Association \\
\hline VOC & volatile organic compound \\
\hline WHRB & waste heat-recovery boiler \\
\hline WI & water injection \\
\hline 2SLB & 2-stroke lean burn engine \\
\hline 4SLB & 4-stroke lean burn engine \\
\hline 4SRB & 4-stroke rich burn engine \\
\hline
\end{tabular}




\section{ACKNOWLEDGMENTS}

The author gratefully acknowledges the U.S. Department of Energy (DOE), Industrial Technologies Program, BestPractices Steam effort for sponsoring the development of this guide and the Office of Distributed Energy for backing this effort. Special thanks are extended to Fred Hart, Bob Gemmer, and Merrill Smith of DOE for their support and guidance. Efforts by Bob Bessette of the Council of Industrial Boiler Owners and Randy Rawson of the American Boiler Manufacturers Association to arrange meetings, identify technical reviewers, and forward reviewer comments helped to ensure that the broad interests of the boiler industry are reflected in the guide. Comprehensive review comments offered by Carl Bozzuto of Alstom provided valuable assistance to the author in identifying and describing technical issues that are important to boiler owners and operators. Consultation with Greg Harrell of the University of Tennessee and Randy Hudson and Steve Fischer of the Oak Ridge National Laboratory (ORNL) about the scope and content of the guide are also very much appreciated. The author also gratefully acknowledges Tony Wright and Mitch Olszewski of the Oak Ridge National Laboratory for managing this project, establishing government and industry contacts, and providing helpful comments and suggestions. In addition, much credit is given to Cynthia Southmayd, Brenda Smith, Cindy Johnson, and Don Sharp of ORNL for editing and preparing high-quality versions of the guide for review and publication. 
x vi 


\section{EXECUTIVE SUMMARY}

Competitive pressures to cut costs are requiring many owners and operators of industrial, commercial, and institutional (ICI) boiler systems to use energy more efficiently. As an alternative to producing steam or hot water on site and purchasing electricity from a local power provider, combined heat and power (CHP), or cogeneration, provides boiler owners and operators an opportunity to reduce power purchases by generating some or all of the electricity used by the facility while satisfying thermal energy demand. Through improved efficiency, cogeneration technology has the potential to reduce overall energy expenditures and produce less emissions per delivered unit of output. When effectively applied, a CHP system can make a facility less dependent on the electrical grid or, more commonly, provide increased reliability for a strategic portion of the electric load at the site.

Recognizing that many issues are involved in making informed decisions about CHP systems, the U.S. Department of Energy (DOE) sponsored efforts at the Oak Ridge National Laboratory (ORNL) to develop a guide that presents useful information for evaluating the viability of cogeneration for new or existing ICI boiler installations. Information about cooling, heating, power, and steam technologies developed by the DOE Industrial Technologies Program and the DOE Distributed Energy Program served as valuable resources in preparing this guide. To ensure that the guide covers a broad range of technical and regulatory issues of particular interest to the commercial boiler industry, the guide was developed in cooperation with the American Boiler Manufacturers Association (ABMA) and the Council of Industrial Boiler Owners (CIBO).

The guide is organized into topics that address many of the fundamental issues encountered in planning a CHP project and focuses on technical subjects associated with the integration of cogeneration technology into new and existing ICI boiler installations. As discussed in Chap. 1, successful integration of cogeneration technology into new or existing ICI boiler installations involves technical and economic screening followed by detailed engineering design. To assist boiler owners and operators avoid excessive outlays while evaluating the viability of cogeneration technology, the guide discusses technical, economic, and regulatory issues that should be considered during the planning phase of any CHP project. In addition, the guide identifies many of the potential benefits and possible barriers to successful implementation. Use of this information will help answer the following important questions.

1. Is cogeneration technically feasible?

2. Is cogeneration economically feasible?

3. Can strategies be developed for overcoming barriers to implementation?

Information presented in Chap. 2 addresses a variety of cogeneration technology issues to serve as a foundation for subsequent discussions. Descriptions and schematics of topping- and bottoming-cycle thermodynamic processes are presented because they represent the two fundamental heat-recovery schemes commonly used in industrial CHP applications. Discussions in Chap. 2 also focus on existing energy and environmental regulations that influence the way CHP systems are designed and operated. Requirements in these regulations can affect the economic viability of a project because emissions control equipment needed for environmental compliance generally adds to the cost of a CHP system. Other important issues covered in Chap. 2 include benefits of cogeneration technology, the various operating modes that can be employed to achieve a particular strategic objective, and a summary of the major barriers to implementation. Understanding the fundamentals of cogeneration technology, being aware of federal laws and regulations that affect CHP construction and operation, and knowing the barriers to implementation are essential to evaluating CHP viability.

To ensure that boiler owners and operators have access to the information they need to evaluate CHP potential at their site, the guide also includes information about various prime movers, waste heat- 
recovery units, electrical generators, and cooling equipment commonly used in industrial CHP applications.

Characteristic features of prime movers used in CHP systems are presented in Chap. 3. A prime mover is a machine or mechanism that converts energy into work. Prime movers commonly used in industrial CHP applications include steam turbines, gas turbines, microturbines, and reciprocating engines. Their primary function is to convert the energy released from fuel into mechanical energy or shaft power. This power is typically used to turn an electrical generator, but it can also be used to power other types of rotating machinery. Fuel cells represent another type of energy conversion device that is sometimes used as a prime mover in CHP applications. Although fuel cells do not produce shaft power, they are capable of converting energy to electricity through an electrochemical process that does not involve fuel combustion. Descriptions of turbine-based and non-turbine-based prime movers are presented, and schematics of typical prime mover configurations used in CHP applications are shown to promote an understanding of their functional capabilities and operational requirements.

Heat-recovery equipment that captures thermal energy rejected from prime movers and other heating sources and makes it available for useful purposes is discussed in Chap. 4. This equipment is important to the success of a CHP system because it extracts thermal energy from exhaust gas streams and liquid coolant circuits, thereby increasing overall energy efficiency. Simple heat-recovery units function as heat exchangers by transferring thermal energy from one system to another. These units are characterized as unfired heat-recovery units because they receive thermal energy from an independent heating source and have no ability to generate additional heat. More complex units are characterized as supplementary fired heat-recovery units because they include both heat transfer surfaces and fuel-firing equipment. These units are designed to supplement the heat provided by the primary heating source with thermal energy generated by combustion of additional fuel. Depending on the process heating and power requirements of the installation, it may be necessary to use both fired and unfired heat-recovery units in the same CHP system. The various types of heat-recovery equipment discussed in Chap. 4 include

- unfired and supplementary fired heat-recovery steam generators,

- heat-recovery mufflers,

- regenerators,

- recuperators,

- ebullient cooling systems,

- forced circulation systems,

- aftercoolers,

- heat exchangers, and

- ICI boilers.

Electrical energy produced by a CHP system may be used on site to reduce power purchases or exported to the electrical grid for resale. Even for CHP systems that produce more power than they consume, connection to the electrical grid is generally necessary for either supplementary or emergency power. Although CHP systems can be developed and operated without relying on purchased power, connection of the CHP system to the electrical grid is generally preferred because it provides increased reliability and operating flexibility. Text in Chap. 5 discusses electrical generators and inverters commonly used in CHP systems to produce electricity as well as other important issues, such as control systems, safety, liability, and interconnection considerations associated with connecting the electrical grid to the site electrical distribution system. 
Although heat and electricity are the two types of energy most often produced by a CHP system, other devices such as cooling equipment and rotating machinery are sometimes part of cogeneration projects because they provide an alternative to conventional electric motor drive systems and offer flexibility in meeting operational requirements. Discussions about absorption chillers and desiccant dehumidifiers that use thermal energy to produce a cooling effect and rotating machinery, such as air compressors, pumps, fans, and refrigeration compressors, that uses mechanical energy to produce useful work are presented in Chap. 6.

Achieving optimum energy efficiency involves maximizing the work output for a given amount of fuel used and minimizing heat rejection from the CHP system. This is accomplished by selectively arranging a series of thermodynamic processes into a cycle where heat is continuously converted to work. For CHP projects, heat-recovery schemes are classified as either topping-cycle or bottoming-cycle systems depending on the sequence the fuel energy is used. Because all CHP systems are designed to convert heat to work on a continuous basis by selectively arranging a series of thermodynamic processes into one or more cycles, attention in Chap. 7 focuses on describing heat-recovery schemes that are compatible with new and existing ICI boiler installations. These schemes include ICI boilers capable of generating hot water or steam and a prime mover capable of generating electricity or producing useful mechanical energy. Configurations of each scheme are provided to help boiler owners and operators quickly identify alternative CHP equipment arrangements for further study and evaluation.

Boiler owners and operators interested in incorporating cogeneration technology into new or existing ICI boiler installations must first develop preliminary designs for candidate CHP systems. Each design should include CHP equipment that is compatible with the physical characteristics and operating objectives of the facility. Developing preliminary designs for CHP systems that satisfy these criteria requires consideration of thermodynamic cycles, prime movers, fuels, and heat-recovery equipment options. To help focus this effort, equipment options for the following 12 CHP system configurations are presented in Chap. 8.

- Back-pressure steam turbine topping-cycle CHP system

- Extraction-condensing steam turbine topping-cycle CHP system

- Open-cycle gas turbine topping-cycle CHP system

- Open-cycle gas turbine topping-cycle CHP system (with recuperator)

- Microturbine topping-cycle CHP system (with conventional generator)

- Microturbine topping-cycle CHP system (with high-speed generator)

- Reciprocating engine topping-cycle CHP system

- Fuel cell topping-cycle CHP system

- Bottoming-cycle CHP system

- Combined-cycle CHP system

- Combined-cycle CHP system (with feedwater heating)

- Trigeneration CHP system

Each configuration lists the heat-recovery equipment options, fuel options, options for using mechanical and thermal energy, potential air emissions, and emission control options that may apply. This information is presented using the format shown in Fig. ES.1 and is useful in establishing preliminary CHP system designs for further consideration.

Because many decisions are required to evaluate the feasibility of cogeneration technology at a particular ICI boiler installation, it is important to keep in mind the diverse nature of the technical and 


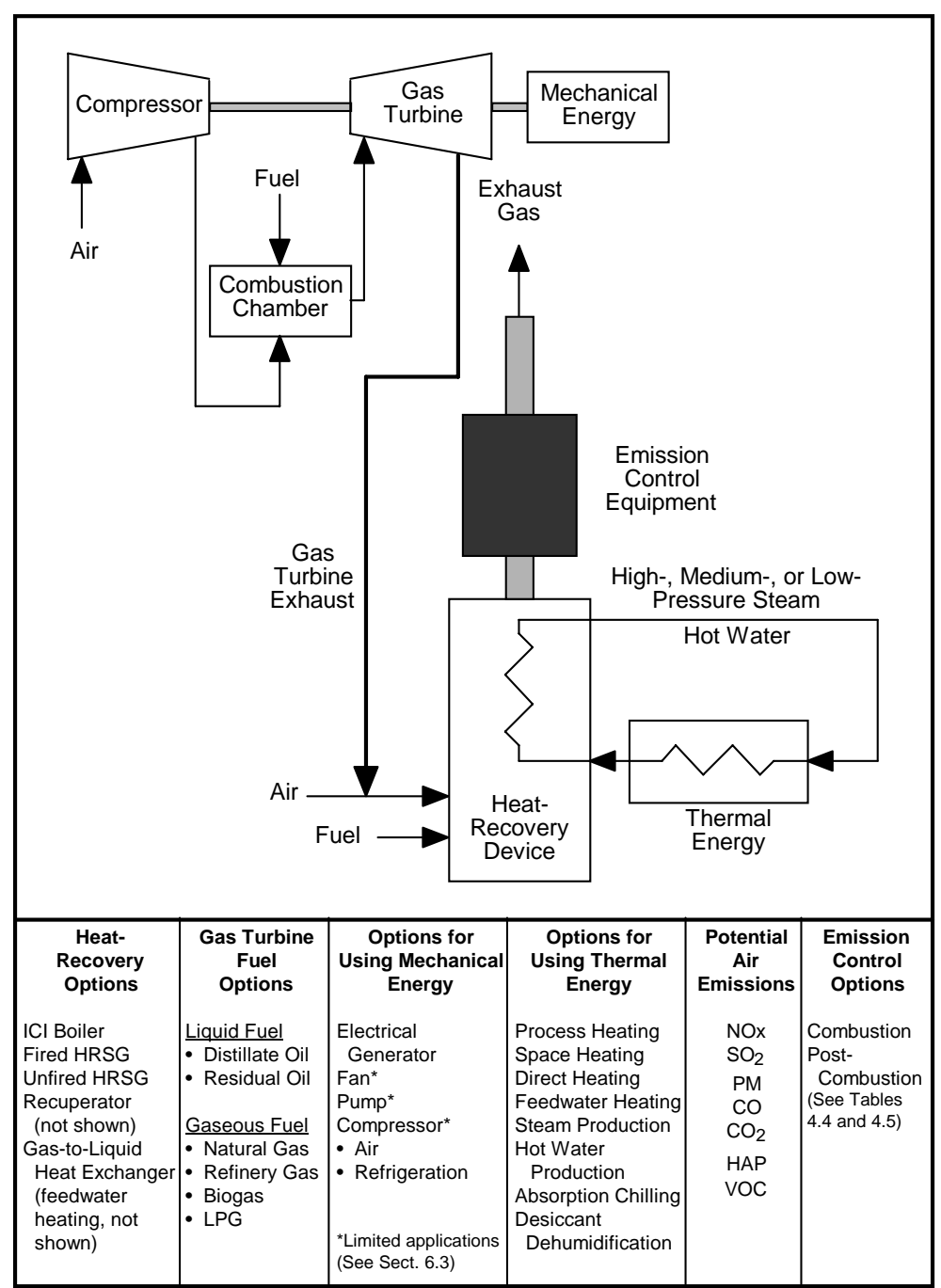

Fig. ES.1. Format for presenting CHP system options.

economic issues that need to be considered in the decision-making process. Evaluating cogeneration potential is a multistage process that begins with an understanding of the infrastructure and operating requirements of the ICI boiler installation. Another strategic element is the identification of facility goals and objectives that can be used as screening criteria throughout the evaluation process. For some installations, the primary goal is to reduce the amount of purchased electricity and replace it with lower cost electricity generated on site. Tools and resources that are available for obtaining site-specific data; identifying energy saving opportunities; performing preliminary screening assessments; preparing preliminary designs; conducting detailed screening analyses; addressing health, safety, and environmental issues; and understanding electrical grid interconnection issues are discussed in Chap. 9. Figure ES.2 illustrates a suggested framework for evaluating the viability of a CHP project. Only when analysis suggests that a CHP system is both technically and economically feasible and that applicable barriers to implementation can be overcome is there reason to continue with the planning process, including detailed engineering design.

Although implementing a CHP project is not technically feasible at every ICI boiler installation and the payback may be somewhat longer than other steam system improvement options, many boiler owners and operators find cogeneration technology to be a cost-effective savings opportunity. The following 


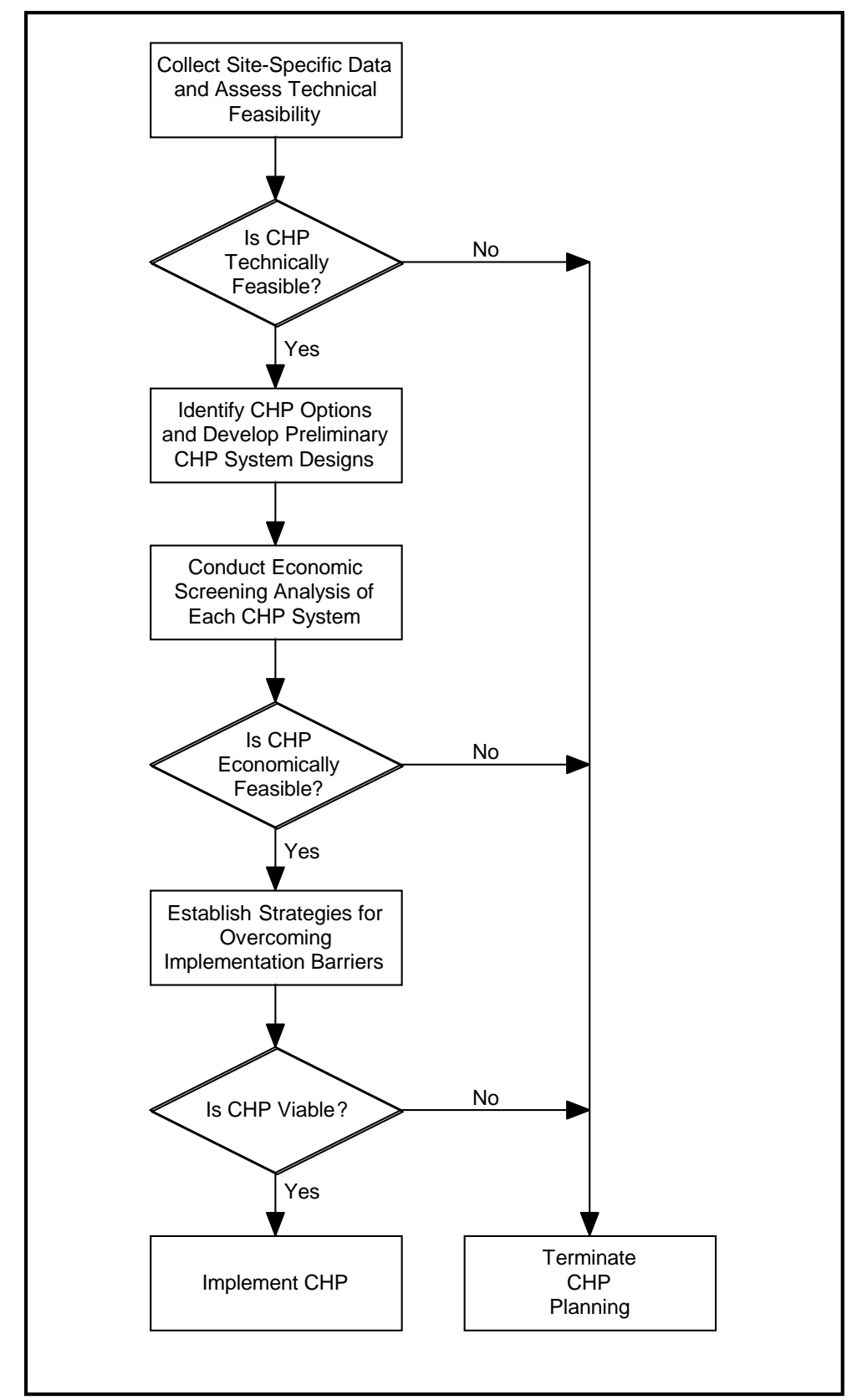

Fig. ES.2. Framework for evaluating CHP viability.

factors enhance the potential of successfully applying cogeneration technology at new or existing ICI boiler installations.

1. The CHP system is sized to satisfy the thermal needs of the process. In some, but not all cases, oversized systems are generally more costly and less efficient.

2. Unless inexpensive solid, liquid, or gaseous fuels are available, natural gas is the preferred fuel for most new CHP applications because of its low emissions and generally wide availability.

3. To enable efficient electric power generation, it may be necessary to generate thermal energy at substantially higher pressures and temperatures than that needed for process applications. 
4. Heat load and power demand occur simultaneously.

5. In general, simultaneous demands for heat and power must be present for at least 4,500 h/year, although there are applications where CHP systems may be cost-effective with fewer hours. For example, when electricity rates are high or when the local power provider offers incentives, this operating period could be as low as 2,200 h/year. The most cost-effective applications are those that operate continuously $(8,760 \mathrm{~h} /$ year $)$.

6. Power-to-heat ratio for the plant should not fluctuate more than $10 \%$.

7. Appropriate cogeneration technology is commensurate with the required power-to-heat ratio of the installation.

8. The viability of cogeneration technology depends on energy prices. The highest potential for CHP occurs when the price for purchased electricity is high while the price for CHP fuel is low.

9. The economic feasibility of a CHP system is inversely related to capital and maintenance costs. In other words, the higher the capital costs or the higher the maintenance costs, the less likely CHP will be economically viable.

10. The CHP system needs to have high availability.

Studies sponsored by DOE suggest that there are up to $140 \mathrm{GW}$ of on-site power generating opportunities in the industrial sector and up to $75 \mathrm{GW}$ of additional on-site power generating opportunities in the commercial and institutional sectors. Because boilers are widely used within these sectors, there is significant potential for integrating cogeneration technology into new and existing ICI boiler installations and thereby reducing overall energy consumption. 


\section{INTRODUCTION}

Combined heat and power (CHP) or cogeneration is the sequential production of two forms of useful energy from a single fuel source. In most CHP applications, chemical energy in fuel is converted to both mechanical and thermal energy. The mechanical energy is generally used to generate electricity, while the thermal energy or heat is used to produce steam, hot water, or hot air. Depending on the application, CHP is referred to by various names including Building Cooling, Heating, and Power (BCHP); Cooling, Heating, and Power for Buildings (CHPB); Combined Cooling, Heating, and Power (CCHP); Integrated Energy Systems (IES), or Distributed Energy Resources (DER).

The principal technical advantage of a CHP system is its ability to extract more useful energy from fuel compared to traditional energy systems such as conventional power plants that only generate electricity and industrial boiler systems that only produce steam or hot water for process applications. ${ }^{1}$ By using fuel energy for both power and heat production, CHP systems can be very energy efficient and have the potential to produce electricity below the price charged by the local power provider. Another important incentive for applying cogeneration technology is to reduce or eliminate dependency on the electrical grid. For some industrial processes, the consequences of losing power for even a short period of time are unacceptable.

A major economic incentive for applying cogeneration technology is to reduce operating expenses by generating electricity at a lower cost than it can be purchased from the local power provider. ${ }^{2}$ Optimum conditions for implementing cogeneration occur when the price of electricity is high and rising and the price of fuel is low. Economic viability of cogeneration is sharply influenced by the marginal cost of generating electricity. This cost is a function of capital investments and production expenses, including fixed charges, fuel payments, and operational and maintenance costs. In assessing economic viability, it is important to calculate the production costs of electricity as an excess above the generating costs of thermal energy alone and then to compare the cost of production with the cost of purchased electricity. ${ }^{2}$ Based on results of this comparison, a decision can be made about proceeding with the CHP project or terminating all planning efforts. For situations where the cost of fuel needed to generate a unit of electricity exceeds the unit cost of purchased electricity, the decision to proceed must be based on other criteria such as improved electric reliability because cogeneration is not a viable economic option. The sensitivity of natural-gas-powered cogeneration's economic viability to fuel cost was recently studied. ${ }^{3}$ Results indicate that the total market potential varies from 18 to 53 gigawatts $(\mathrm{GW})$ when the well head price of natural gas varies from $\$ 5.00$ to $\$ 2.50$ per million cubic feet.

Competitive pressures to cut costs by conserving energy are requiring many owners and operators of industrial, commercial, and institutional (ICI) boiler systems to look for ways to use energy more efficiently. As an alternative to producing steam or hot water on site and purchasing electricity from a local power provider, cogeneration provides boiler owners and operators an opportunity to independently generate electricity and thermal energy and thereby lower operating costs by reducing overall energy expenditures. Effective application of cogeneration technology generally results in increased fuel costs and reduced electricity costs.

Information presented in the guide is primarily intended for boiler owners, boiler operators, energy managers, and project planners interested in improving energy efficiency and lowering operating costs at ICI boiler installations through the application of cogeneration technology. Boilers at these installations use the chemical energy in fuel to raise the energy content of water so that it can be used for process heating applications. Industrial boilers are used extensively in the chemical, food processing, forest products, and petroleum industries. Commercial and institutional boilers are used in many other applications, including commercial businesses, office buildings, apartments, hotels, restaurants, hospitals, schools, museums, government buildings, and airports.

This guide was prepared at the Oak Ridge National Laboratory (ORNL) for the U.S. Department of Energy (DOE) with support and cooperation from the Industrial Technologies Program (ITP) and the 
Distributed Energy (DE) Program. To ensure that the guide covers a broad range of technical and regulatory issues of particular interest to the commercial boiler industry, the guide was developed in cooperation with the American Boiler Manufacturers Association (ABMA) and the Council of Industrial Boiler Owners (CIBO).

\subsection{SCOPE AND OBJECTIVES}

The primary objective of the guide is to present information needed to evaluate the viability of cogeneration for new or existing ICI boiler installations and to make informed CHP equipment selection decisions. Information presented is meant to help boiler owners and operators understand the potential benefits derived from implementing a CHP project and recognize opportunities for successful application of cogeneration technology. Topics covered in the guide follow:

- an overview of cogeneration technology with discussions about

$\checkmark$ benefits of applying cogeneration technology

$\checkmark$ barriers to implementing cogeneration technology

- applicable federal regulations and permitting issues

- descriptions of prime movers commonly used in CHP applications, including discussions about

$\checkmark$ design characteristics

$\checkmark$ heat-recovery options and equipment

$\checkmark$ fuels and emissions

$\checkmark$ efficiency

$\checkmark$ maintenance

$\checkmark$ availability

$\checkmark$ capital cost

- electrical generators and electrical interconnection equipment

- cooling and dehumidification equipment

- thermodynamic cycle options and configurations

- steps for evaluating the technical and economic feasibility of applying cogeneration technology

- information sources

Discussions in the guide concentrate on CHP systems that can be integrated into new or existing ICI boiler installations. A series of CHP configurations is also presented to help boiler owners and operators identify viable cogeneration options for technical and economic evaluation. Configurations that are described include

- steam turbine topping-cycle systems, including back-pressure turbine and extraction-condensing turbine systems

- open-cycle gas turbine topping-cycle systems

- closed-cycle gas turbine topping-cycle systems

- reciprocating engine topping-cycle systems

- fuel cell topping-cycle systems

- microturbine topping-cycle systems

- bottoming-cycle systems 
- combined-cycle systems

- trigeneration systems

To reduce possible confusion with terminology and promote a better understanding of relevant issues, a glossary, list of acronyms, and references are also included. This information will be useful to boiler owners and operators interested in learning more about cogeneration technology and its potential application to ICI boiler installations.

\subsection{APPROACH}

Successful integration of cogeneration technology into new or existing ICI boiler installations can be challenging because CHP systems are unlimited in their thermodynamic possibilities, and thus in the configuration and sizing of the various components. In addition, the design, arrangement, and cost of components is often influenced by process temperature requirements, pressure limits, fuel type and availability, process heating demand, and electric power needs. From an engineering viewpoint, application of cogeneration technology is a matter of cycle selection and design of piping and valving arrangements, and not of basic differences in boilers, turbines, heat exchangers, and electrical generators. However, it is important for boiler owners and operators to consider alternative CHP equipment combinations because differences in performance and applicability can have a significant effect on project economics.

Decisions about applying cogeneration technology need to reflect as much site-specific information as possible. An approach that is often effective involves comparing the costs and economic benefits of an existing or benchmark boiler installation to those for alternative schemes that integrate cogeneration technology into their design. ${ }^{4}$ Because so many factors that need to be considered are influenced by conditions at the site, technical and economic assessments performed for one installation may have limited applicability to other locations. The key to meaningful analysis involves developing preliminary designs of technically feasible CHP systems. These designs need to include sufficient technical detail to allow accurate estimates of construction and operating costs, electricity and CHP fuel consumption rates, air and water emissions, and potential cost savings. Although preparing preliminary designs for alternative CHP systems is a necessary step in the overall decision-making process, there is no assurance that the time, effort, and investment will result in reduced energy costs.

Implementing cogeneration technology involves technical and economic screening followed by detailed engineering design. ${ }^{5}$ The process begins by determining if a site is suitable for cogeneration, identifying the required capacity of the CHP equipment, and estimating construction and operating costs. During the evaluation, key issues such as energy requirements, mechanical and electrical systems, electricity rates and tariffs, fuel price and availability, space requirements, regulatory requirements, health and safety issues, and operational factors should be considered. At some point early in this process, the boiler owner or operator needs to make a key decision about whether or not to connect the CHP system to the electrical grid. If the CHP system is connected to the electrical grid, another decision must be made about using all of the electricity generated by the CHP system on site or selling excess electricity to the local power provider. If the CHP is not connected to the electrical grid, then the CHP system must have sufficient capacity to satisfy the critical electrical needs of the facility with a reserve margin for shortterm transients. These determinations will influence the size of the CHP system and therefore project economics.

To assist boiler owners and operators in avoiding excessive outlays while evaluating the viability of cogeneration technology at a particular site, manpower and resources should initially focus on answering the following three questions. 
1. Is cogeneration technically feasible?

2. Is cogeneration economically feasible?

3. Can strategies be developed for overcoming barriers to implementation?

Only when analysis suggests that a CHP system is both technically and economically feasible and applicable barriers to implementation can be overcome is there reason to continue with the planning process, including detailed engineering designs. The high cost of engineering and the risk of technical, economic, and environmental failure, as well as regulatory restraints, mandate care and skill to successfully design and build a custom-engineered CHP system. ${ }^{6}$

\subsection{COGENERATION OPPORTUNITIES}

Studies sponsored by DOE suggest that there are up to $140 \mathrm{GW}$ of on-site power-generating opportunities in the industrial sector ${ }^{7-9}$ and up to $75 \mathrm{GW}$ of additional on-site power-generating opportunities in the commercial and institutional sectors. ${ }^{10,11}$ Because boilers are widely used within these sectors, there is significant potential for integrating cogeneration technology into new and existing ICI boiler installations. Although implementing a CHP project is not technically feasible at every boiler installation and the payback may be somewhat longer than other steam system improvement options, many ICI boiler owners and operators find cogeneration technology to be a cost-effective savings opportunity. ${ }^{12-16}$ New or existing boiler installations with high CHP potential usually fit the following profile, but CHP may also be viable at installations meeting only a few of these criteria: $9,10,17,18$

- high electricity prices (greater than $\$ 0.05 / \mathrm{kWh}$ ),

- high electricity demand and peak energy usage charges,

- average electric load greater than about $1 \mathrm{MW}$,

- ratio of average electric load to peak load exceeding about 0.7,

- additional process heat needed,

- cost of CHP fuel is low compared to electricity rates,

- high annual operating hours,

- thermal demand closely matching electric load,

- steady thermal loads or steady process waste heat streams, and

- issues concerning energy security and reliability.

Most new CHP applications use gas turbines or reciprocating engines coupled to an electrical generator. Heat recovered from these prime movers is then used to produce steam or hot water, to meet space heating or cooling requirements, or to control humidity. These systems may include heat exchangers, absorption chillers, desiccant dehumidifiers, or other types of heat-recovery equipment. In another common CHP application, boiler steam passes through a steam turbine to generate electricity. Heat rejected from the steam turbine is then used for process applications. One of the simplest strategies for implementing cogeneration technology is to replace steam-pressure-reducing valves with backpressure steam turbines and electrical generators.

The following factors enhance the potential of successfully applying cogeneration technology at new or existing ICI boiler installations. 
1. The CHP system is sized to satisfy the thermal needs of the process. In some, but not all cases, oversized systems are generally more costly and less efficient.

2. Unless inexpensive solid, liquid, or gaseous fuels are available, natural gas is the preferred fuel for most new CHP applications because of its low emissions and generally wide availability.

3. To enable efficient electric power generation, it may be necessary to generate thermal energy at substantially higher pressures and temperatures than that needed for process applications.

4. Heat load and power demand occur simultaneously.

5. In general, simultaneous demands for heat and power must be present for at least 4,500 h/year, although there are applications where CHP systems may be cost effective with fewer hours. For example, when electricity rates are high or when the local power provider offers incentives, this operating period could be as low as 2,200 h/year. The most cost-effective applications are those that operate continuously $(8,760 \mathrm{~h} /$ year $)$.

6. Power-to-heat ratio for the plant should not fluctuate more than $10 \%$.

7. Appropriate cogeneration technology is commensurate with the required power-to-heat ratio of the installation.

8. The viability of cogeneration technology depends on energy prices. The highest potential for CHP occurs when the price for purchased electricity is high while the price for CHP fuel is low.

9. The economic feasibility of a CHP system is inversely related to capital and maintenance costs. In other words, the higher the capital costs or the higher the maintenance costs, the less likely CHP will be economically viable.

10. The CHP system needs to have high availability.

\subsection{REFERENCES}

1. Industrial and Commercial Cogeneration, Office of Technology Assessment, Congressional Board of the 98th Congress, Washington, D.C., February 1983.

2. Combined Heat and Power: A Federal Manager's Resource Guide, prepared by Aspen Systems Corp. for the U.S. Department of Energy, Washington, D.C., March 2000.

3. DG Monitor, Vol. III, Issue 4, Resource Dynamics Corporation, Vienna, Virginia, July/August 2003.

4. "Cogeneration Ready Reckoner," User's Manual, Version 3.1, Commonwealth Department of Industry, Tourism, and Resources, Commonwealth of Australia, September 2002.

5. "Introduction to Large-Scale Combined Heat and Power," Good Practice Guide 43, prepared for the Department of the Environment, Transportation, and the Regions by ETSU, Oxfordshire, England, March 1999.

6. "Cogeneration Systems and Engine and Turbine Drives," Chapter 7, ASHRAE HandbookHVAC Systems and Equipment, American Society of Heating, Refrigerating and Air-Conditioning Engineers, Inc., Atlanta, Georgia, July 6, 2000.

7. Assessment of Replicable Innovative Industrial Cogeneration Applications, Resource Dynamics Corp., Vienna, Virginia, June 2001.

8. Steam System Opportunity Assessment for the Pulp and Paper, Chemical Manufacturing, and Petroleum Refining Industries, DOE/GO-102002-1639, Office of Industrial Technologies, U.S. Department of Energy, Washington, D.C., September 2002. 
9. T. Bryson, W. Major, and K. Darrow, Assessment of On-Site Power Opportunities in the Industrial Sector, ORNL/TM-2001/169, prepared by Onsite Energy Corp. for the Oak Ridge National Laboratory, Oak Ridge, Tennessee, September 2001.

10. CHP Potential at Federal Sites, Office of Energy Efficiency and Renewable Energy, U.S. Department of Energy, Washington, D.C., May 2000.

11. The Market and Technical Potential for Combined Heat and Power in the Commercial/Institutional Sector, prepared for the U.S. Department of Energy by ONSITE SYCOM Energy Corporation, Washington, D.C., January 2000 (Revision 1).

12. Cogeneration Handbook for the Chemical Process Industry, DOE/NBB-0059, prepared by Pacific Northwest National Laboratory for the U.S. Department of Energy, Washington, D.C., February 1984.

13. Cogeneration Handbook for the Food Processing Industry, DOE/NBB-0061, prepared by Pacific Northwest National Laboratory for the U.S. Department of Energy, Washington, D.C., February 1984.

14. Cogeneration Handbook for the Petroleum Refining Industry, DOE/NBB-0060, prepared by Pacific Northwest National Laboratory for the U.S. Department of Energy, Washington, D.C., February 1984.

15. Cogeneration Handbook for the Pulp and Paper Industry, DOE/NBB-0057, prepared by Pacific Northwest National Laboratory for the U.S. Department of Energy, Washington, D.C., February 1984.

16. Cogeneration Handbook for the Textile Industry, DOE/NBB-0058, prepared by Pacific Northwest National Laboratory for the U.S. Department of Energy, Washington, D.C., February 1984.

17. Steam System Opportunity Assessment for the Pulp and Paper, Chemical, Manufacturing, and Petroleum Refining Industries, Main Report, DOE/GO-102002-1639, U.S. Department of Energy, Washington, D.C., September 2002.

18. Steam System Opportunity Assessment for the Pulp and Paper, Chemical, Manufacturing, and Petroleum Refining Industries, Appendices, DOE/GO-102002-1640, U.S. Department of Energy, Washington, D.C., October 2002. 


\section{COGENERATION TECHNOLOGY ISSUES}

Well-designed CHP systems integrate proven technologies for electric power generation and thermal load management to maximize overall efficiency. Unlike conventional fossil-fired steam turbine power plants that discharge up to $65 \%$ of the energy potential as waste heat, CHP systems are designed to capture much of the otherwise wasted thermal energy from electric power production and make it available for process applications. Depending on the mix of power and thermal requirements, overall efficiency can vary from about $35 \%$ for end users with low heating requirements to $85 \%$ or more for end users with low-power requirements. Through improved efficiency, CHP systems have the potential to consume less fuel and produce less emissions per delivered unit of output. When effectively applied, a CHP system can make a facility less dependent on the electrical grid or, more commonly, provide increased reliability for a strategic portion of the electric load at the site.

Installing CHP equipment at new or existing boiler installations provides a means for adding electric generating capacity to sites that already need to produce thermal energy. Selecting cogeneration technology for a specific ICI boiler application depends on many factors, including the electricity and steam or hot water demand, the duty cycle, space constraints, process requirements, emission regulations, fuel availability, electric rates, and electrical grid interconnection issues. From a practical viewpoint, CHP systems can produce different proportions of electricity and steam, but process pressures and temperatures have a direct influence on the design, arrangement, and cost of CHP components. The electricity-to-steam ratio (E/S) refers to the relative proportions of electric and thermal energy produced by the CHP equipment. The E/S ratio is measured in kilowatt hours per million British thermal unit ( $\mathrm{kWh} / \mathrm{MMBtu})$ of steam (or useful thermal energy), and it varies among the different types of cogeneration technologies.

The following discussions describe the concept of CHP and provide background information about applying cogeneration technology in the United States. Details about prime movers, heat-recovery components, electric power generation, and cooling equipment included in various types of CHP systems are presented in subsequent chapters. Understanding the fundamentals of cogeneration technology, being aware of federal laws and regulations that affect CHP construction and operation, and knowing the barriers to implementation are essential to evaluating CHP viability.

\subsection{TECHNOLOGY DESCRIPTION}

Cogeneration technology combines electrical and mechanical equipment into an operating system designed to convert fuel energy into both electric power and useful thermal energy. The automobile engine is a familiar application of cogeneration technology. Besides providing mechanical shaft power to move the vehicle, it also produces electricity with an alternator to run the electrical system and recirculates hot water from the engine to provide space heating when needed. ${ }^{1}$

For most industrial applications, CHP systems consist of three basic elements, including a prime mover, an electrical generator, and components for waste heat recovery. Some systems even include cooling equipment when a cooling effect is needed. The role of the prime mover is to drive the electrical generator. Steam turbines, gas turbines, and reciprocating engines are common types of prime movers used in industrial CHP systems, but fuel cells and microturbines can also be used for this purpose. Waste heat recovery normally takes place in a boiler, heat-recovery steam generator (HRSG), heat-recovery muffler, or another type of heat exchanger. Types of prime movers, waste heat-recovery units, electrical generators, and cooling equipment commonly used in industrial CHP systems are identified and described in Chaps. 3 to 6, respectively.

To fully understand cogeneration technology potential, it is important to realize that CHP systems are designed to convert heat to work on a continuous basis by selectively arranging a series of thermodynamic processes into a cycle. ${ }^{2}$ Heat-recovery schemes for cogeneration technology are classified as either topping-cycle or bottoming-cycle systems depending on the sequence the fuel energy is used. ${ }^{3}$ 
In topping-cycle systems, the energy in fuel is first used to generate electricity. Waste heat from the prime mover is then recovered and used for process heating or cooling applications. Figure 2.1 illustrates energy flow in a topping cycle. Prime movers for most industrial topping-cycle CHP systems include steam turbines, gas turbines, reciprocating engines, fuel cells, and microturbines. Details about specific topping-cycle systems for ICI boiler applications are presented in Sect. 7.1.

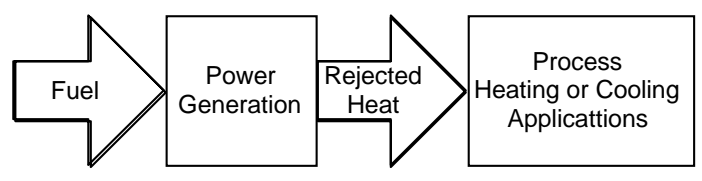

Fig. 2.1. Topping-cycle schematic.

In bottoming-cycle systems, high-temperature thermal energy is produced and first used for industrial applications, such as glass processing and metal smelting furnaces. Waste heat recovered from the industrial process is then used to drive a turbine to produce electric power. Bottoming-cycle systems are generally used in industrial processes that reject very high-temperature heat. Consequently, bottoming-cycle CHP systems are less common that topping-cycle CHP systems. Figure 2.2 illustrates energy flow in a bottoming cycle. Discussions about bottoming-cycle CHP systems for ICI boiler applications are provided in Sect. 7.2.

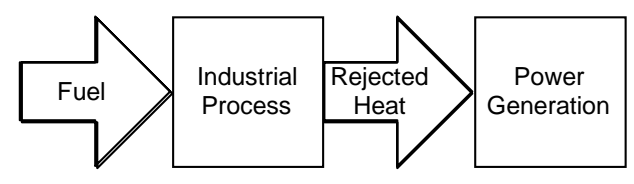

Fig. 2.2. Bottoming-cycle schematic.

Although topping-cycle and bottoming-cycle systems represent the two fundamental thermodynamic process arrangements for cogeneration technology, it is possible to use both cycles in the same system to create what is commonly referred to as a combined-cycle system. In these systems, electricity is produced by two separate electrical generators. One generator is part of the topping-cycle system, while the other is part of the bottoming-cycle system. Information about combined-cycle CHP systems for ICI boiler applications is presented in Sect. 7.3. When cooling equipment such as an absorption chiller is added to a combined-cycle CHP system, the design is called a trigeneration system. Trigeneration systems for ICI boiler applications are discussed in Sect. 7.4.

Almost any type of solid, liquid, or gaseous fuel can be used to produce heat needed to generate electricity, but prime movers, boilers, and HRSGs for industrial CHP systems are typically designed for a specific type of fuel or fuel combination. Fuel availability, price, handling, transportation, and storage can also influence the selection and design of CHP equipment. At locations with strict environmental regulations, CHP systems that use solid fuels such as coal typically include emissions control equipment for limiting sulfur dioxide $\left(\mathrm{SO}_{2}\right)$, nitrogen oxides $\left(\mathrm{NO}_{\mathrm{x}}\right)$, particulate matter $(\mathrm{PM})$, or other regulated air pollutant releases. For these systems, the cost of achieving the required air quality can be so expensive that alternative fuels such as natural gas are often the only practical fuel option.

In establishing performance requirements for a CHP system, it is important to quantify thermal and electric load patterns and to identify the preferred operating mode. These factors need to be considered when selecting and sizing the equipment so that the system is capable of delivering the specified amounts 
of steam and electricity to satisfy process requirements. For example, a CHP system that generates electricity on a continuous basis to support a base load typically has different performance, and thus equipment requirements, than a CHP system that adjusts output based on demand.

Although power quality and reliability issues are sometimes used to justify the installation of a CHP system, the primary economic reason for integrating cogeneration technology into a new or existing boiler installation is to decrease operating expenses by reducing the amount of purchased energy. Criteria for assessing economic viability potential are presented in Fig. 2.3. In general, if the cost of electricity generated on site exceeds the cost of purchased electricity, cogeneration technology is not economical. Quantifying cost savings potential requires comparing the cost of fuel used by the CHP system for electricity production to the cost of a corresponding amount of purchased electricity. In determining if a CHP project will provide the desired economic benefit, the boiler owner or operator must establish an acceptable minimum cost difference between electricity generated on site vs purchased electricity. This difference is key to determining the project payback. For most boiler installations, the lower the cost of fuel for the CHP system or the higher the cost of purchased electricity, the more likely the CHP project will yield acceptable economic benefits.

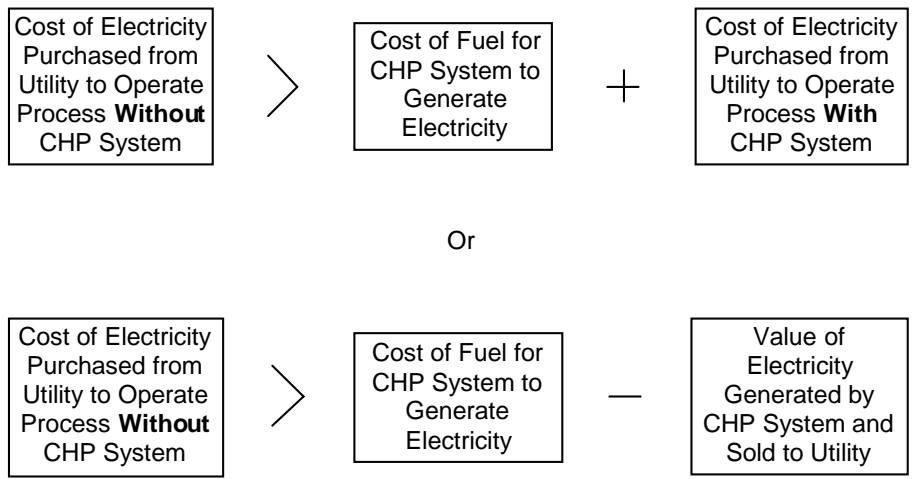

Fig. 2.3. Criteria for assessing economic viability potential of cogeneration technology.

\subsection{NATIONAL ENERGY ACTS}

Energy availability and pricing issues in the 1970s promoted interest in energy conservation and energy efficiency. In response to these concerns, the National Energy Acts were signed into law in 1978 to establish a foundation for a comprehensive national energy policy. Objectives of the legislation were to reduce dependence on foreign oil, to promote alternative energy sources and energy efficiency, and to diversify the electric power industry. The five statutes that make up the National Energy Acts are identified by the following titles and Public Law numbers.

- Public Utility Regulatory Policies Act-P.L. 95-617

- Energy Tax Act-P.L. 95-618

- National Energy Conservation Policy Act-P.L. 95-619

- Powerplant and Industrial Fuel Use Act-P.L. 95-620

- Natural Gas Policy Act—P.L. 95-621

The Public Utility Regulatory Policies Act (PURPA) was enacted to augment electric utility generation with more efficiently produced power. To achieve this objective, PURPA created a new class 
of nonutility generators and sought to promote energy-efficient and economic cogeneration by requiring utilities to purchase power from cogeneration facilities and those fueled by renewable resources. With the enactment of PURPA, the first wholesale markets for power were created for electricity from cogeneration and renewable resources. Electric utilities are required by PURPA to interconnect to certain cogenerators and small power producers (SPPs) with $80 \mathrm{MW}$ or less of generating capacity and allow them to operate in parallel with the electrical grid. However, before certain utilities will allow connection to the grid, cogenerators and SPPs are required to pay for some or all of the interconnection costs and to meet the utility's protective and safety requirements. Even though nonutility power producers are permitted to connect to the electrical grid, utilities are responsible for the stability and reliability of the grid.

Section 210 of PURPA requires utilities to purchase excess electricity generated by "qualified facilities" (QFs) and to provide backup power at a reasonable cost. Qualified facilities included plants that use renewable resources or cogeneration technologies to produce electricity. According to PURPA, cogenerators must use at least $5 \%$ of their thermal output for process or space heating (10\% for facilities that burn oil or natural gas). In some cases, this requirement historically forced independent cogenerators to sell steam at very low rates in order to become a QF under PURPA.

Although utilities are required to purchase excess power produced by cogenerators and SPPs, the purchase price for the power is based on the avoided cost of the electric utility as determined by the Public Utility Commission. The cost to the utility of producing or otherwise procuring that extra power is referred to as "avoided cost." Typically, the avoided cost is determined to be the cost of electricity produced by the next new power plant. Utilities with excess power generation capacity often have extremely low avoided costs. The Public Utility Commission determines this cost to be the cost of fuel. This situation can create barriers to cogeneration.

Changes in the tax code in 1981 provided cogenerators with important tax benefits affecting depreciation schedules and investment tax credits. These changes were responsible for injecting significant amounts of money into the cogeneration industry. However, the tax benefits enacted in 1981 were eliminated in the mid-1980s.

The 1992 Energy Policy Act (EPACT)-P.L. 102-486 took the next steps in creating a more competitive marketplace for electricity generation by opening access to transmission networks and exempting some nonutilities from certain regulatory requirements, allowing their participation in wholesale electric power sales. This legislation created a new class of power generators known as Exempt Wholesale Generators (EWGs). These generators are exempt from the Public Utility Holding Company Act (PUHCA) of 1935 and can sell power competitively to wholesale customers. A cogeneration facility can be (but does not have to be) a QF under PURPA and an EWG under EPACT. This happens when the facility is in the exclusive business of wholesale power sales and makes no retail power sales to its "steam host" or customer.

Electric utilities are required by PURPA to interconnect with and buy, at the utility's avoided cost, electricity produced by any nonutility facility that meets certain criteria established by the Federal Energy Regulatory Commission (FERC). In 1996, FERC issued two orders further impacting cogeneration. Order 888 established wholesale competition by opening transmission access to non-utilities, and Order 889 required utilities to establish electronic systems to share information about available transmission capacity. For a nonutility to be classified as a QF under PURPA, it must meet certain ownership, operating, and efficiency criteria established by FERC. The operating requirements stipulate the proportion of output energy that must be thermal energy, and the efficiency requirements stipulate the maximum ratio of input energy to output energy. The QFs are either small-scale producers of commercial energy who normally self-generate energy for their own needs but may have occasional or frequent surplus energy, or they are incidental producers who happen to generate usable electric energy as a byproduct of other activities. When a facility of this type meets FERC requirements for ownership, size, and efficiency, utility companies are obliged to purchase energy from these facilities at the utility's 
avoided cost. To meet FERC ownership, operating, and efficiency requirements, the following criteria must be satisfied. ${ }^{4}$

- The ownership standard requires that no more than $50 \%$ of a facility be owned by electric utilities or electric utility holding companies, either single or in partnership. This standard applies to both topping- and bottoming-cycle systems.

- The operating standard requires that a minimum of $5 \%$ of the useful output of a cogeneration system be in the form of useful thermal energy. This standard only applies to topping-cycle systems.

- The efficiency standard requires that the efficiency of a cogeneration system, as defined below, be at least $45 \%$ for topping cycles; if the amount of useful thermal energy produced by the cogeneration system exceeds $15 \%$, then the efficiency threshold decreases to $42.5 \%$. This standard only applies to topping-cycle systems. There is no efficiency standard for a bottoming cycle or for renewable resources. According to FERC rules, efficiency is defined as the sum of the power output of the cogeneration system plus half of the useful thermal output divided by the energy input, with the energy input measured as the fuel's lower heating value.

Besides federal regulations governing cogeneration, state regulatory authorities also have the authority to regulate all cogeneration power purchased by a utility. Consequently, states indirectly control the rates paid to cogenerators by utilities through their power to approve the cost of purchased power.

\subsection{ENVIRONMENTAL REGULATIONS}

While cogeneration has the potential to improve overall air and water quality by making more efficient use of energy in fuel, emissions are of concern whenever fossil fuels, biomass, and waste fuels are burned. All new cogeneration plants are subject to the Environmental Protection Agency (EPA) permitting process designed to meet National Ambient Air Quality Standards (NAAQS). In addition to these minimum federal standards, many states impose stricter regulations than EPA. This added regulation can significantly increase the initial cost of some cogeneration facilities, especially those located in urban areas that do not meet NAAQS for certain pollutants. Compliance with applicable regulations can affect the economic viability of some cogeneration plants because the emissions control equipment required to meet environmental regulations adds to the cost of the project.

\subsubsection{Clean Air Act}

In 1970, the Clean Air Act (CAA) established a major role for the federal government in regulating air quality. ${ }^{5}$ This regulation was further expanded by amendments in 1977 and 1990. The Clean Air Act Amendments (CAAA) of 1990 comprise an extremely lengthy and complex piece of legislation that authorizes the EPA to establish standards for a number of atmospheric pollutants. ${ }^{6}$ Compliance with applicable portions of the regulation requires an understanding of the original act that was signed into law in 1970, the various amendments that have since been adopted, changes promulgated by EPA, and numerous rulings issued by the judicial system.

The CAAA of 1990 are subdivided into the following seven major titles that address specific air quality and pollution issues.

Title I: Provisions for Attainment and Maintenance of National Ambient Air Quality Standards (NAAQS)

Title II: Provisions Relating to Mobile Sources

Title III: Air Toxics

Title IV: Acid Deposition Control

Title V: Permits 
Title VI: Stratospheric Ozone and Global Climate Protection

Title VII: Provisions Relating to Enforcement

Even though cogeneration has the potential to reduce total air emissions through improved energy efficiency, requirements in Titles I, III, IV, and V have, or may have in the future, an impact on the feasibility of integrating CHP systems into new or existing ICI boiler installations.

Title I contains requirements for achieving national air quality goals. Under Sect. 109, EPA is authorized to establish primary and secondary NAAQS. These standards represent the maximum allowable concentration of a pollutant permitted in the ambient air. Primary ambient air quality standards define levels of air quality that EPA considers necessary, with an adequate margin of safety, to protect the public health. Secondary ambient air quality standards are intended to protect the public welfare from any known or adverse effects of a pollutant. Both standards are subject to revision, and additional primary and secondary standards may be promulgated, as the EPA Administrator deems necessary to protect the public health and welfare.

Under Sect. 110 of Title I, states are required to adopt plans for implementing, maintaining, and enforcing NAAQS in each air quality control region within its jurisdiction. Such plans are known as State Implementation Plans (SIPs). These plans establish emission standards for specific sources. To achieve compliance, states are subdivided into a number of identifiable areas known as air quality control regions in which at least the minimum NAAQS must be met or control requirements imposed. If the level of a regulated pollutant exceeds the specified federal standard within a particular region, it is classified as a nonattainment area (NAA). When a region fails to meet a NAAQS, more stringent emission control requirements, designed to reduce emission levels and thereby achieve attainment, must be applied. As in prior environmental legislation, local or state environmental regulatory agencies may impose stricter regulations on individual sources or areas.

Authorization for EPA to establish performance standards for new stationary emission sources is provided in Sect. 111 of Title I. These New Source Performance Standards (NSPS) establish maximum emission rates for selected pollutants from new emission sources and existing units that undergo substantial modifications. This legislation ensures that standard emissions controls are applied uniformly in all areas, irrespective of ambient air quality considerations. According to the legislation, the degree of emissions limitation is achieved through the application of the best system of emission reduction that has been adequately demonstrated. These systems are referred to as best available control technology (BACT).

Title III amended Sect. 112 of the CAA regarding requirements for reducing toxic air emissions by establishing National Emission Standards for Hazardous Air Pollutants (NESHAP). A toxic air pollutant, or hazardous air pollutant (HAP), is any one of the nearly 200 pollutants considered by EPA to be hazardous to human health or the environment. Often characterized as carcinogens, mutagens, or reproductive toxins, HAPs are subdivided into the following groups:

- metals, including cadmium, mercury, lead, and fine PM;

- $\quad$ organics, including dioxins and furans; and

- $\quad$ acid gases, including hydrogen chloride, $\mathrm{SO}_{2}$, and $\mathrm{NO}_{\mathrm{x}}$.

The CAAA of 1990 include a comprehensive plan for achieving significant reductions in HAP emissions from major sources. According to the definition in Sect. 112, a major source is any stationary source or group of stationary sources located within a contiguous area and under common control that emits or has the potential to emit considering controls, in the aggregate, 10 tons/year or more of any HAP or 25 tons/year or more of any combination of HAPs. To establish regulations for HAP emissions, EPA developed and published a list of major source categories. Based on this list, EPA has either issued or is now developing Maximum Achievable Control Technology (MACT) standards for each listed source 
category. These standards are based on the best demonstrated control technology or practice within the regulated industry. Currently, EPA has established MACT standards for certain HAP sources, including hazardous waste combustion units. ${ }^{7}$ Discussions about proposed MACT standards for stationary ICI boilers, gas turbines, and reciprocating engines are presented in Sect. 2.3.1.3.

When developing a MACT standard for a particular source category, EPA looks at the level of emissions currently being achieved by the best-performing similar sources through clean processes, control devices, work practices, or other methods. These emissions levels set a baseline (often referred to as the "MACT floor") for the new standard. At a minimum, a MACT standard must achieve, throughout the industry, a level of emissions control that is at least equivalent to the MACT floor. The MACT floor is established differently for existing sources and new sources. For existing sources, the MACT floor must equal the average emissions limitations currently achieved by the best-performing $12 \%$ of sources in that source category, provided 30 or more existing sources are within the category. If there are fewer than 30 existing sources, then the MACT floor must equal the average emissions limitation achieved by the bestperforming five sources in the category. For new sources, the MACT floor must equal the level of emissions control currently achieved by the best-controlled similar source. Wherever feasible, EPA writes the final MACT standard as an emissions limit (i.e., as a percent reduction in emissions or a concentration limit that regulated sources must achieve). Emissions limits provide flexibility for industry to determine the most effective way to comply with the standard.

Title IV establishes requirements for significantly reducing $\mathrm{NO}_{\mathrm{x}}$ and $\mathrm{SO}_{2}$ emissions. To achieve this statutory goal, EPA established the Acid Rain Program. Its objective is to reduce adverse effects of acid deposition by controlling $\mathrm{SO}_{2}$ and $\mathrm{NO}_{\mathrm{x}}$ emissions from fossil-fuel-fired power plants. Requirements for $\mathrm{SO}_{2}$ emissions are contained in Sect. 403. This section addresses the $\mathrm{SO}_{2}$ allowance program for new and existing units and establishes a market-based approach to $\mathrm{SO}_{2}$ emission reductions. Separate requirements for $\mathrm{NO}_{\mathrm{x}}$ emissions are provided in Sect. 407. These requirements are part of the EPA's $\mathrm{NO}_{\mathrm{x}}$ emission reduction program. Acid Rain Program regulations have been codified in Title 40, Subchapter C of the Code of Federal Regulations. ${ }^{8-12}$

Title V contains legislation covering federal and state air permitting programs that apply to major sources of atmospheric pollution. Specific definitions of major sources are spelled out in Sects. 112 and 302 of the legislation. Each permit issued under this title must include enforceable emission limitations and standards, a schedule of compliance, and a requirement that the permit applicant submit the results of required monitoring to the permitting authority. Regulations that provide for the establishment of comprehensive state air quality permitting systems consistent with Title $\mathrm{V}$ requirements are contained in 40 CFR Part 70 (Ref. 13). Additional regulations that establish certain general provisions and the operating permit program requirements for affected sources and affected units under the Acid Rain Program are contained in 40 CFR Part 72 (Ref. 8). Units affected by this regulation are identified in 40 CFR 72.6 and 40 CFR Part 74 (Ref. 9).

Although EPA recognizes that CHP offers energy and environmental benefits over electric-only systems, in both central power generation and distributed generation applications, its current administrative policies and permitting procedures do not allow emission reductions from one source (electric utility steam generating units) to be used to offset increased emissions from another source such as a CHP system. Consequently, permit applications for most CHP systems must address increased air emissions resulting from additional on-site fuel consumption.

To encourage the implementation of cogeneration technology, EPA is preparing a number of tools that may help boiler owners and operators make informed decisions about CHP viability. These tools include an emissions calculator to help energy users estimate the potential environmental benefits of replacing or upgrading their existing energy assets to incorporate CHP, a permitting primer to help energy users and project developers understand the permitting process, and a handbook for use by air regulators in developing output-based emissions standards. ${ }^{14}$ According to EPA, the permitting primer will cover the basics of CAA regulations and describe the process for seeking a permit for a CHP project. 


\subsubsection{National Ambient Air Quality Standards}

Six criteria pollutants are covered by the NAAQS in 40 CFR Part 50 (Ref. 15). They include $\mathrm{NO}_{\mathrm{x}}$, $\mathrm{SO}_{2}$, $\mathrm{PM}$, ozone $\left(\mathrm{O}_{3}\right)$, carbon monoxide $(\mathrm{CO})$, and lead $(\mathrm{Pb})$. The primary and secondary standards for each of these pollutants except lead are summarized in Table 2.1. Standards for lead are not covered because it is not a major pollutant from combustion of fossil fuels. Currently, the only combustion units that must comply with lead emission standards are large municipal waste combustion units. ${ }^{16}$

An area where the level of a criteria pollutant is above the primary standard is classified as an NAA. These areas are subject to more stringent requirements aimed at reducing emissions to achieve attainment. Attainment areas include areas where the level of a criteria pollutant is below the primary standard. As the regulation is written, it is possible for a source to be located in an area that is classified as an NAA for one or more pollutants and an attainment area for the others.

The NAA maps for each of the six criteria pollutants can be generated using an interactive tool (http://www.epa.gov/air/data/nonat.html?us USA United\%20States) provided by EPA. This tool uses color shading to indicate whether an entire county or only part of the county exceeds NAAQS. A special selection option allows the user to create enhanced maps, showing features such as city locations, highways, and national park outlines.

Owners and operators of boiler installations that add cogeneration must meet emissions requirements established by EPA and must obtain a permit from the regulatory authority having jurisdiction before the system can be operated. Emission controls that must be installed, and the conditions under which the system is allowed to operate often vary from one location to another. This variation is due the local air quality and the degree to which the local atmospheric conditions deviate from the NAAQS. In general, emission control requirements are more stringent for systems located in NAAs than for systems located in attainment areas.

\subsubsection{New Source Performance Standards}

The EPA has established standards of performance for new stationary emission sources, including gas (combustion) turbines and boilers used in CHP systems. These NSPS are codified in 40 CFR Part 60 (Ref. 17). and cover maximum emission rates and required reductions in potential combustion concentrations for $\mathrm{PM}, \mathrm{SO}_{2}$, and $\mathrm{NO}_{\mathrm{x}}$ (expressed as $\mathrm{NO}_{2}$ ). Potential combustion concentration means the theoretical emissions in pounds per million British thermal units (MMBtu) heat input that would result from combustion of fuel in an uncleaned state without emission control systems. In this context, new source refers to a unit for which construction or modification commenced after a prescribed date.

Standards of performance for new stationary sources that have been issued by EPA for waste combustion units, ICI boilers, incinerators, electric utility steam generating units, and combustion turbines that could be included as part of a CHP system are identified in Table 2.2. Maximum emission rates and required reductions in potential combustion concentrations for regulated boilers and steam generating units are summarized in Appendix A of Ref. 18. At this time, EPA has not established NSPS for stationary reciprocating internal combustion engine. However, proposed rules ${ }^{19}$ for reducing emissions at major HAP emission sources would be effective in decreasing $\mathrm{PM}, \mathrm{NO}_{\mathrm{x}}$, and $\mathrm{CO}$ emissions from RICE.

\subsubsection{National Emission Standards for HAP}

National emission standards for HAPs are provided in 40 CFR 63 (Ref. 20). These standards regulate a wide range of stationary source categories that emit (or have the potential to emit) one or more HAPs listed in Sect. 112(b) of the CAA as amended in 1990. Some of the regulated sources could potentially provide heat for bottoming-cycle CHP systems, while others such as hazardous waste 
Table 2.1. Summary of NAAQS under Title I of the CAA ${ }^{a}$

\begin{tabular}{|c|c|c|}
\hline Criteria pollutant & Primary standards & Secondary standards \\
\hline $\begin{array}{l}\mathrm{O}_{3} \\
40 \text { CFR } 50.9 \text { and } \\
\quad 50.10\end{array}$ & $\begin{array}{l}\text { The primary } 1-\mathrm{h} \text { ambient air quality standard } \\
\text { for ozone is } 0.12 \mathrm{ppm} \text {, daily maximum } 8 \text {-h } \\
\text { average. This standard is attained when the } \\
\text { expected number of days per calendar year } \\
\text { with maximum hourly average concentra- } \\
\text { tions above } 0.12 \mathrm{ppm} \text { is equal to or less than } \\
\text { one. } \\
\text { The primary } 8 \text {-h ambient air quality standard } \\
\text { for ozone is } 0.08 \mathrm{ppm} \text {, daily maximum } 8 \text {-h } \\
\text { average. This standard is met at a monitoring } \\
\text { site when the average of the annual fourth- } \\
\text { highest daily maximum } 8 \text {-h average of ozone } \\
\text { concentration is less than or equal to } \\
0.08 \mathrm{ppm} \text {. }\end{array}$ & $\begin{array}{l}\text { The secondary ambient air quality stan- } \\
\text { dards for ozone are the same as the } \\
\text { primary standards. }\end{array}$ \\
\hline $\begin{array}{l}\mathrm{NO}_{2} \\
40 \text { CFR } 50.11\end{array}$ & $\begin{array}{l}\text { The primary ambient air quality standard for } \\
\mathrm{NO}_{2} \text { is } 0.053 \mathrm{ppm} \text {, annual arithmetic mean } \\
\text { concentration. }\end{array}$ & $\begin{array}{l}\text { The secondary ambient air quality stan- } \\
\text { dards for } \mathrm{NO}_{2} \text { are the same as the } \\
\text { primary standards. }\end{array}$ \\
\hline $\begin{array}{l}\mathrm{SO}_{2} \\
40 \text { CFR } 50.4 \text { and } \\
50.5\end{array}$ & $\begin{array}{l}\text { The primary annual ambient air quality stan- } \\
\text { dard for } \mathrm{SO}_{2} \text { is } 0.030 \mathrm{ppm} \text {, not to be } \\
\text { exceeded in a calendar year. The } 24-\mathrm{h} \text { stan- } \\
\text { dard is } 0.14 \mathrm{ppm} \text {, not to be exceeded more } \\
\text { than once per calendar year. }\end{array}$ & $\begin{array}{l}\text { The secondary } 3-\mathrm{h} \text { ambient air quality } \\
\text { standard for } \mathrm{SO}_{2} \text { is } 0.5 \mathrm{ppm} \text {, not to be } \\
\text { exceeded more than once per calendar } \\
\text { year. }\end{array}$ \\
\hline $\begin{array}{l}\mathrm{CO} \\
40 \text { CFR } 50.8\end{array}$ & $\begin{array}{l}\text { The primary ambient air quality standards for } \\
\text { CO are } 9 \text { ppm for an } 8 \text {-h average concentra- } \\
\text { tion not to be exceeded more than once per } \\
\text { calendar year, and } 35 \mathrm{ppm} \text { for a } 1 \text {-h average } \\
\text { concentration not to be exceeded more than } \\
\text { once per calendar year. }\end{array}$ & $\begin{array}{l}\text { There are no secondary ambient air quality } \\
\text { standards for CO. }\end{array}$ \\
\hline $\begin{array}{l}\mathrm{PM} \text { up to } 10 \mu \mathrm{m} \text { in } \\
\text { diameter }\left(\mathrm{PM}_{10}\right) \\
40 \mathrm{CFR} 50.6\end{array}$ & $\begin{array}{l}\text { The primary } 24-\mathrm{h} \text { ambient air quality standard } \\
\text { for } \mathrm{PM}_{10} \text { is } 150 \mu \mathrm{g} / \mathrm{m}^{3}, 24-\mathrm{h} \text { average } \\
\text { concentration. } \\
\text { The primary annual ambient air quality } \\
\text { standard for } \mathrm{PM}_{10} \text { is } 50 \mu \mathrm{g} / \mathrm{m}^{3} \text {, annual } \\
\text { arithmetic mean concentration. }\end{array}$ & $\begin{array}{l}\text { The secondary ambient air quality stan- } \\
\text { dards for } \mathrm{PM}_{10} \text { are the same as the } \\
\text { primary standards. }\end{array}$ \\
\hline $\begin{array}{l}\text { PM up to } 2.5 \mu \mathrm{m} \text { in } \\
\text { diameter }\left(\mathrm{PM}_{2.5}\right) \\
40 \text { CFR } 50.7\end{array}$ & $\begin{array}{l}\text { The primary } 24-\mathrm{h} \text { ambient air quality standard } \\
\text { for } \mathrm{PM}_{2.5} \text { is } 65 \mu \mathrm{g} / \mathrm{m}^{3}, 24-\mathrm{h} \text { average } \\
\text { concentration. } \\
\text { The primary annual ambient air quality } \\
\text { standard for } \mathrm{PM}_{2.5} \text { is } 15.0 \mu \mathrm{g} / \mathrm{m}^{3} \text {, annual } \\
\text { arithmetic mean concentration. }\end{array}$ & $\begin{array}{l}\text { The secondary ambient air quality stan- } \\
\text { dards for } \mathrm{PM}_{2.5} \text { are the same as the } \\
\text { primary standards. }\end{array}$ \\
\hline
\end{tabular}

${ }^{a}$ Consult 40 CFR 50 for NAAQS details. 15 
Table 2.2. Standards of performance for new stationary steam generating sources $a$

\begin{tabular}{|c|c|}
\hline $\begin{array}{l}40 \text { CFR } 60 \\
\text { Subpart }\end{array}$ & Title \\
\hline $\mathrm{Cb}$ & $\begin{array}{l}\text { Emissions Guidelines and Compliance Times for Large Municipal Waste Combustors that are } \\
\text { Constructed on or Before September 20,1994 }\end{array}$ \\
\hline $\mathrm{Ce}$ & $\begin{array}{l}\text { Emission Guidelines for Hospital/Medical/Infectious Waste Incinerators Constructed on or } \\
\text { before June } 20,1996\end{array}$ \\
\hline $\mathrm{D}$ & $\begin{array}{l}\text { Standards of Performance for Fossil-Fuel-Fired Steam Generators for Which Construction is } \\
\text { Commenced After August 17, 1971 }\end{array}$ \\
\hline $\mathrm{Da}$ & $\begin{array}{l}\text { Standards of Performance for Electric Utility Steam Generating Units for Which Construction } \\
\text { is Commenced After September 18, } 1978\end{array}$ \\
\hline $\mathrm{Db}$ & Standards of Performance for Industrial-Commercial-Institutional Steam Generating Units \\
\hline Dc & $\begin{array}{l}\text { Standards of Performance for Small Industrial-Commercial-Institutional Steam Generating } \\
\text { Units }\end{array}$ \\
\hline $\mathrm{E}$ & Standards of Performance for Incinerators \\
\hline $\mathrm{Ea}$ & $\begin{array}{l}\text { Standards of Performance for Municipal Waste Combustors for Which Construction is } \\
\text { Commenced After December 20, 1989, and on or Before September 20, } 1994\end{array}$ \\
\hline $\mathrm{Eb}$ & $\begin{array}{l}\text { Standards of Performance for Large Municipal Waste Combustors for Which Construction is } \\
\text { Commenced After September 20, 1994, or for Which Modification or Reconstruction is } \\
\text { Commenced After June 19,1996 }\end{array}$ \\
\hline Ec & $\begin{array}{l}\text { Standards of Performance for Hospital/Medical/Infectious Waste Incinerators for Which } \\
\text { Construction is Commenced After June 20,1996 }\end{array}$ \\
\hline GG & Standards of Performance for Stationary Gas Turbines ${ }^{b}$ \\
\hline AAAA & $\begin{array}{l}\text { Standards of Performance for Small Municipal Waste Combustion Units for Which } \\
\text { Construction is Commenced After August 30, 1999, or for Which Modification or } \\
\text { Reconstruction is Commenced After June 6, 2001 }\end{array}$ \\
\hline BBBB & $\begin{array}{l}\text { Emission Guidelines and Compliance Times for Small Municipal Waste Combustion Units } \\
\text { Constructed on or Before August 30, } 1999\end{array}$ \\
\hline $\mathrm{CCCC}$ & $\begin{array}{l}\text { Standards of Performance for Commercial and Industrial Solid Waste Incineration Units for } \\
\text { Which Construction is Commenced After November 30, 1999, or for Which Modification or } \\
\text { Reconstruction is Commenced on or After June 1, 2001 }\end{array}$ \\
\hline DDDD & $\begin{array}{l}\text { Emissions Guidelines and Compliance Times for Commercial and Industrial Solid Waste } \\
\text { Incineration Units that Commenced Construction on or Before November 30, } 1999\end{array}$ \\
\hline EEEE & $\begin{array}{l}\text { New Source Performance Standards for Other Solid Waste Incinerators Constructed after } \\
\text { November 30, } 1999 \text { (under development by EPA) }\end{array}$ \\
\hline FFFF & $\begin{array}{l}\text { Emission Guidelines for Other Solid Waste Incinerators Constructed on or before } \\
\text { November 30, } 1999 \text { (under development by EPA) }\end{array}$ \\
\hline
\end{tabular}

${ }^{a}$ Performance standards for additional facilities and industrial processes are provided in 40 CFR 60 (Ref. 17).

$b_{68}$ FR 17990 (Ref. 21).

combustors $^{7}$ could be part of topping-cycle CHP systems. In an effort to further reduce toxic air emissions, EPA is finalizing national emission standards for HAPs for the following types of combustion units that are often used in CHP systems:

- ICI boilers and process heaters, ${ }^{22,23}$

- stationary combustion turbines, ${ }^{24}$ and

- stationary reciprocating internal combustion engines. ${ }^{19}$

Rules for these units implement Sect. 112(d) of the CAA by requiring affected major sources to meet HAP emissions standards reflecting the applicable MACT. A major source is one that emits 10 tons/year 
or more of a single toxic air pollutant, or 25 tons/year or more of a combination of air pollutants. The rules set limits on the amount of air pollution that may be released by a major source. Meeting the emission limits could be achieved by either (1) installing emission control equipment such as fabric filters or scrubbers or (2) switching fuel to one that produces fewer toxic emissions. These MACT standards will appear in the Code of Federal Regulation in the subparts identified in Table 2.3.

Boilers and process heaters affected by the rule 22,23 are used at facilities such as refineries, chemical and manufacturing plants, and paper mills. According to EPA, an estimated 58,000 existing boilers and process heaters will be subject to the rule requirements. New boilers and process heaters would have up to 6 months after the rule is final, or 6 months after startup, to comply with the new requirements. By adopting the standard, EPA anticipates substantially reduced emissions of toxic air pollutants, such as cadmium, chromium, lead, arsenic, manganese, mercury, hydrogen fluoride, nickel, and hydrogen chloride from these source categories. The date the final rule for boilers and process heaters ${ }^{25}$ will published in the Federal Register has not been announced by EPA.

Proposed rules for stationary combustion turbines ${ }^{24}$ have been finalized by EPA to reduce emissions of a number of toxic air pollutants including formaldehyde, toluene, acetaldehyde, and benzene. The final rule $^{25}$ was published in the Federal Register on March 5, 2004, and applies to combustion turbines with a rated peak power output equal to or greater than 1.0 MW located at major sources of HAP emissions. Eight subcategories have been defined within the stationary combustion turbine source category, and each subcategory has distinct requirements. New combustion turbines would have up to 6 months after the

Table 2.3. MACT standards for steam generating source categories ${ }^{a}$

\begin{tabular}{|c|c|c|}
\hline $\begin{array}{l}40 \text { CFR } 63 \\
\text { Subpart }\end{array}$ & Title & Reference \\
\hline EEE & $\begin{array}{l}\text { National Emission Standards for Hazardous Air Pollutants for } \\
\text { Hazardous Waste Combustors }\end{array}$ & Ref. 7 \\
\hline \multirow[t]{3}{*}{ YYYY } & $\begin{array}{l}\text { Proposed Rule: National Emission Standards for Hazardous Air } \\
\text { Pollutants for Stationary Gas Turbines, } 68 \text { FR } 1888\end{array}$ & Ref. 24 \\
\hline & $\begin{array}{l}\text { National Emission Standards for Hazardous Air Pollutants for } \\
\text { Stationary Combustion Turbines-Proposed Delisting, OAR-2003- } \\
\text { 0189; RIN 2060-AK73, U.S. Environmental Protection Agency, } \\
\text { Washington, D.C. }\end{array}$ & Ref. 26 \\
\hline & $\begin{array}{l}\text { National Emission Standards for Hazardous Air Pollutants for } \\
\text { Stationary Combustion Turbines-Stay Proposal, OAR-2003- } \\
\text { 0196; RIN 2060-AK73, U.S. Environmental Protection Agency, } \\
\text { Washington, D.C. }\end{array}$ & Ref. 27 \\
\hline \multirow[t]{2}{*}{ ZZZZ } & $\begin{array}{l}\text { Proposed Rule: National Emission Standards for Hazardous Air } \\
\text { Pollutants for Stationary Reciprocating Internal Combustion } \\
\text { Engines, } 67 \text { FR } 77830\end{array}$ & Ref. 19 \\
\hline & $\begin{array}{l}\text { Final Rule: National Emission Standards for Hazardous Air } \\
\text { Pollutants for Stationary Reciprocating Internal Combustion } \\
\text { Engines, OAR-2002-0059; RIN 2060-AG-63, U.S. Environmental } \\
\text { Protection Agency, Washington, D.C. }\end{array}$ & Ref. 28 \\
\hline \multirow[t]{2}{*}{ DDDDD } & $\begin{array}{l}\text { Proposed Rule: National Emission Standards for Hazardous Air } \\
\text { Pollutants for Industrial/Commercial/Institutional Boilers and } \\
\text { Process Heaters, } 68 \text { FR } 1660\end{array}$ & Ref. 22 \\
\hline & $\begin{array}{l}\text { Final Rule: National Emission Standards for Hazardous Air } \\
\text { Pollutants for Industrial, Commercial, and Institutional Boilers and } \\
\text { Process Heaters, OAR-2002-0058; RIN 2060-AG69, U.S. } \\
\text { Environmental Protection Agency, Washington, D.C. }\end{array}$ & Ref. 23 \\
\hline
\end{tabular}

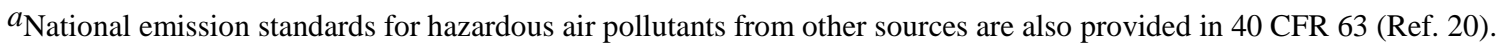


rule is final, or 6 months after startup, to comply with the new requirements. Existing combustion turbines will need to achieve compliance within 3 years after the rule is final. Affected sources may install controls known as CO catalytic oxidation systems or other means to reduce emissions. The final rule was based on CO catalytic oxidation system technology, which is capable of reducing $\mathrm{CO}$ emissions as well as other toxic emissions such as formaldehyde, toluene, acetaldehyde, and benzene. Combustion turbines located at area sources of HAP emissions are not covered by the final rule. An area source of HAP emissions is a site that does not emit any single HAP at a rate of 10 tons/year or a combination of HAPs at a rate of 25 tons/year.

Although rules for gas turbines are published in the Federal Register, ${ }^{25}$ on March 31, 2004, EPA proposed a rule that would remove four of the eight subcategories of combustion turbines from MACT standards. ${ }^{26}$ The four subcategories the EPA is proposing to remove from emissions control are (1) lean premix gas-fired turbines, (2) diffusion flame gas-fired turbines, (3) emergency stationary combustion turbines, and (4) stationary combustion turbines operated on the North Slope of Alaska. With the exception of the emergency turbines, these turbines primarily burn natural gas and may use oil as a backup (no more than 1,000 h/year). The emergency turbines mostly burn oil. On March 31, 2004, EPA also proposed to stay, or delay, the enforcement of the combustion turbines HAP emissions standards for new turbines in the lean premix gas-fired turbines and diffusion flame gas-fired turbines subcategories. ${ }^{27}$

The objective of the emission standards 19,28 for stationary RICE is to reduce emissions of hydrocarbons, $\mathrm{PM}, \mathrm{NO}_{\mathrm{x}}$, and $\mathrm{CO}$. As drafted, the rule only applies to engines with a manufacturer's nameplate rating above 500 brake horsepower that are located at major sources of HAP emissions. To comply with the new requirements, facilities with new or existing spark ignition 4-stroke rich burn (4SRB) engines may install nonselective catalytic reduction systems or other systems that are capable of reducing formaldehyde emissions to $350 \mathrm{ppb}$ or less. For new spark ignition 2-stroke lean burn (2SLB) and 4-stroke lean burn (4SLB) engines and for compression ignition (CI) engines the proposed rule requires installation of either a control device known as a $\mathrm{CO}$ catalytic oxidation system, or other systems capable of reducing formaldehyde emissions to the following prescribed levels.

- $17 \mathrm{ppm}$ for 2SLB engines

- 14 ppm for 4SLB engines

- $580 \mathrm{ppb}$ for $\mathrm{CI}$ engines

With the exception of existing spark ignition 4SRB stationary RICE, other types of stationary RICE (i.e., 2SLB, 4SLB, and CI) located at existing major sources of HAP emissions are not subject to any specific requirements under the rule. The date the final rule for stationary RICE $^{28}$ will published in the Federal Register has not been announced by EPA.

\subsubsection{Permitting requirements}

Title I, Parts C and D of the CAA establish permitting requirements for construction and operation of new and modified major stationary sources of regulated air pollutants. Collectively, EPA refers to these programs as the major New Source Review (NSR) program. The NSR provisions of the CAA are combinations of air quality planning and air pollution control technology program requirements. Major NSR program regulations are contained in 40 CFR 51.165 (Ref. 29), 40 CFR 51.166 (Ref. 30), 40 CFR 52.21 (Ref. 31), 40 CFR 52.24 (Ref. 32), and 40 CFR 51, Appendix S (Ref. 33).

In administering the major NSR program, states must develop, adopt, and submit to EPA for approval a SIP that contains emission limitations and other control measures to attain and maintain the NAAQS and to meet the other requirements in Sect. 110(a) of the CAA. Each SIP is required to contain a preconstruction review program for the construction and modification of any stationary source of air pollution to assure that the NAAQS are achieved and maintained; to protect areas of clean air; to protect 
Air Quality Related Values (AQRV) (including visibility) in national parks and other natural areas of special concern; to assure that appropriate emissions controls are applied; to maximize opportunities for economic development consistent with the preservation of clean air resources; and to ensure that any decision to increase air pollution is made only after full public consideration of all the consequences of such a decision.

Title $\mathrm{V}$ of the CAA includes provisions for issuance of operating permits by the federal government (EPA) as well as state and local jurisdictions. This provision ensures that mandated emissions limitations and emission reduction requirements are achieved in actual practice. Each permit specifies the enforceable requirements that apply to each affected unit or source. In this context, a source is any governmental, institutional, commercial, or industrial structure, installation, plant, building, or facility that emits a regulated air pollutant.

Except for some very small CHP system, almost every cogeneration project needs some type of NSR permit. Assistance in understanding the permitting process in Illinois is provided in its CHP/BCHP environmental permitting guidebook. ${ }^{34,35}$ Other states including Iowa, New York, and California are developing similar CHP permitting guidebooks. Efforts by DOE in the permitting area involve developing a permitting primer for eight southeastern states and expanding the database of state-specific permit requirements. A comprehensive permit handbook is also be developed by EPA.

One of the first steps in preparing a permit application focuses on determining whether a CHP system is its own source or part of another source, and whether the CHP system is a new source or a modification to an existing source. For new sources, it is important to estimate their potential to emit (PTE). This value often reflects the design operational capability but can also account for operational limits, fuels, and emission controls. For modifications to existing sources, it is necessary to determine the net emissions increase, if any, resulting from the addition of a CHP system and other modifications to the installation that may be necessary. Currently, no credit can be taken for reduced emissions that might occur at a utility power plant after the CHP system begins generating electricity either for use at the site or for resale to the utility. Output-based emission standards to address this issue are being promoted by EPA as incentives for efficiency and cogeneration, and future NSR reforms adopted by EPA may consider CHP source definition and output-based mechanisms.

\section{Construction permits}

Permitting requirements for construction of new and modified major stationary sources depend on the air quality at the location of the source. Regulations for sources located in NAAs (areas not meeting NAAQS) and in ozone transport regions (OTRs), as defined in Sect. 184 of the CAA, are contained in 40 CFR 51.165 (Ref. 29). This part of the major NSR program is referred to by EPA as the nonattainment NSR program. In attainment areas (areas meeting NAAQS) or in areas for which there is insufficient information to determine whether they meet the NAAQS (unclassifiable areas), the NSR requirements are contained in 40 CFR 51.166 (Ref. 30). This program is referred to by EPA as the Prevention of Significant Deterioration (PSD) program.

Determining whether an activity is subject to the major NSR program is fairly straightforward for newly constructed sources. The CAAA of 1990 set applicability thresholds for major sources in NAAs (PTE above 100 tons/year of any regulated criteria pollutant, or smaller amounts, depending on the nonattainment classification) and attainment areas (100 or 250 tons/year, depending on the source type). A new source with a PTE at or above the applicable threshold amount is subject to major NSR. The determination of what should be classified as a modification subject to major NSR presents more difficult issues. Applicability of the major NSR program must be determined in advance of construction and is pollutant-specific. In cases involving existing sources, this requires a pollutant-by-pollutant determination of the emissions change, if any, that will result from the physical or operational change. Revised regulations governing changes in NSR applicability requirements for modifications have been finalized. ${ }^{36}$ 
These changes are based on a review by the EPA Administrator, in consultation with the Secretary of Energy and other relevant agencies, of NSR regulations including administrative interpretations and implementation. The five changes that were made to the NSR program involve baseline actual emissions, actual-to-projected-actual emissions methodology, plantwide applicability limitations (PALs), clean unit exemptions, and pollution control projects (PCP) exemptions. These changes, which became effective March 3, 2003, outline how a major modification is determined under the various major NSR applicability options.

Draft guidance for clarifying EPA's NSR and Title V policies regarding source definitions for CHP facilities was issued in 2001 (Ref. 37). Under current NSR and Title V regulations and guidance, a "stationary source" is any building, structure, facility, or installation that emits or has the PTE any air pollutant subject to regulation under the CAA. The term "building, structure, facility, or installation" means all the pollutant emitting activities that belong to the same industrial grouping, are located on one or more contiguous or adjacent properties and are under the control of the same person (or persons under common control). ${ }^{13,29,31}$ An emissions unit is any part of a stationary source that emits or has the potential to emit any pollutant subject to regulation under the CAA. The term "same industrial grouping" refers to the "major groups" identified by two-digit codes in the Standard Industrial Classification (SIC) Manual, which is published by the Office of Management and Budget. The preamble to the August 7, 1980 PSD regulations explains the EPA's policy about how to make source determinations when facilities at a site are not in the same two-digit SIC code. Essentially, the 1980 PSD preamble provides that activities in different two-digit SIC codes may nevertheless still be aggregated together if one activity is a "support facility" for a primary activity at that plant site. Thus, one source classification encompasses both primary and support facilities, even when the latter includes units with a different two-digit SIC code.

A permit to construct and operate a new or modified major source anywhere in an area that does not meet NAAQS (i.e., NAAs) cannot be issued unless the source is required to comply with the Lowest Achievable Emissions Rate (LAER) as defined in 40 CFR 51.165 (Ref. 29). The meaning of LAER is discussed in Table 2.4. Permits issued to sources located in NAAs are called Nonattainment NSR Permits. To receive one of these permits, emissions offsets must be obtained. An offset is a method used in the CAA to give companies that own or operate large (major) sources in NAAs flexibility in meeting overall pollution reduction requirements when changing production processes. These offsets represent reductions in actual emissions from some other source. This source may be at the same plant or at another plant owned by the applicant or from some other company with a source that is located within the NAA. In actual practice, permit applicants must obtain an offset that is somewhat greater than the amount of pollution they will emit. This ensures that permit requirements are met and the NAA keeps moving toward attainment. The permit applicant must also install pollution control equipment to significantly reduce emissions. Trading offsets are allowed because total pollution levels will continue to decrease using this approach. Revisions in NSR applicability requirements were recently issued by EPA to allow sources more flexibility to response to rapidly changing markets and to plan for future investments in pollution control and prevention technologies. ${ }^{36}$ The desired objectives of these revisions are to increase energy efficiency and encourage emissions reductions.

The PSD regulations in 40 CFR 52.21 (Ref. 31) allow the installation and operation of large new sources and modification of existing sources in areas that meet the NAAQS (i.e., attainment areas). To assure that the area will continue to meet NAAQS, applicants for construction permits must demonstrate that the BACT is being applied. Requirements for BACT determinations are described in Table 2.4.

Draft guidance for determining source boundaries between CHP system that serve one thermal host and CHP systems that serve multiple customers was issued by EPA. ${ }^{37}$ According to this guidance, the definition of "building, structure, facility, or installation" provides three tests: 
Table 2.4. BACT and LAER applicability and requirements

\section{BACT}

BACT: Best Available Control Technology

Applicability: BACT is applicable to new emission sources located in attainment areas. These areas are in compliance with NAAQS. ${ }^{a}$

Requirements: By law, BACT determinations must consider the economic, environmental, and energy impacts of each installation on a case-by-case basis. To satisfy this requirement, a permit applicant must identify all air pollution control options available, the feasibility of applying these options, the effectiveness of each option, and why the option proposed in the application represents BACT. The accepted method for performing these assessments is known as top-down BACT. Implementing top-down BACT requires an assessment of emission control technologies beginning with the technique that is the most effective. If this technique is cost-effective and technically feasible, then it must be applied. However, if the cost is too high or its application is not feasible, the next most effective technique must be assessed until an acceptable technique is identified.

\section{LAER}

LAER: Lowest Achievable Emissions Rate

Applicability: LAER is applicable to new emission sources located in NAAs. These areas are not in compliance with NAAQS. ${ }^{a}$

Requirements: LAER means the more stringent rate of emissions based on the following:

- The most stringent emissions limitation that is contained in the implementation plan of any state for such class or category of stationary source, unless the owner or operator of the proposed stationary source demonstrates that such limitations are not achievable; or

- The most stringent emissions limitation that is achieved in practice by such class or category of stationary sources. This limitation, when applied to a modification, means the LAER for the new or modified emissions units within a stationary source. Under no conditions does the application of the term permit a proposed new or modified stationary source to emit any pollutant in excess of the amount allowable under an applicable new source standard of performance.

LAER is the most stringent of all technology-based regulations and is different from BACT. The costeffectiveness of applying a particular emission control technique cannot be considered in LAER determinations. When required, technology equivalent to LAER must be used regardless of the cost.

${ }^{a}$ Consult 40 CFR 50 for NAAQS details. ${ }^{15}$

1. Is the CHP adjacent or contiguous to the host?

2. Is the CHP under common control with the host?

3. Is the CHP either (a) part of the same SIC code as the host, or if not, (b) is the CHP a support facility for the host?

If the answer to all three tests is "yes," then EPA considers the CHP a single source together with the host. If the answer to any of the three tests is "no," then EPA considers the CHP to be a separate source from the host. This interpretation clarifies that a CHP facility that is capable of providing power or heat not only to the host, but also to the electrical grid or elsewhere, may be considered a separate source from the host for purposes of NSR and Title V permitting. That is, permitting authorities may consider a CHP facility to be a separate source from the host facility, even if the CHP facility continues to provide all or most of its output to the host facility. The feature that distinguishes CHP facilities from other support facilities is the fact that a CHP facility is independently capable of providing power to the electrical grid or customers other than the host facility. This guidance applies even where the CHP facility is not necessarily currently providing power or thermal energy to other customers; it need only possess the 
technical capability to do so. By "technical capability," EPA means that all necessary infrastructure would be in place and that steam or waste heat could be provided "at the turn of a valve." Therefore, if emissions from the CHP facility itself exceed the major stationary source threshold, then, as with any new major stationary source, the CHP facility must go through the PSD or nonattainment NSR permitting process, whichever is appropriate. In addition, PSD regulations require that credible emissions decreases for netting purposes must be from emissions units within the same source, not from emissions units at other sources. Emissions netting is a term that refers to the process of considering certain previous and prospective emissions changes at an existing major source to determine if a "net emissions increase" of a pollutant will result from a proposed physical change or change in method of operation.

\section{Operating permits}

Operating permits issued under Title V must include enforceable emission limitations and standards, a schedule of compliance, and a requirement that the permit applicant submit the results of required monitoring to the permitting authority. Other permitting provisions pertain to the certifying of Designated Representatives for affected sources, schedules for submissions, permit processing and revision procedures, and periodic compliance certification reporting. Permits are subject to public comment before approval and are generally available to the public after they are issued.

Regulations that provide for the establishment of comprehensive state and local air quality permitting systems consistent with the requirements of Title V are contained in 40 CFR Parts 70 and 71 (Refs. 13 and 38). Additional regulations that establish certain general permitting provisions are contained in 40 CFR Part 72 (Ref. 8). The approval status of state and local operating permits programs is presented in 40 CFR Parts 70, Appendix A (Ref. 39).

Operating permit requirements for affected units (i.e., fossil-fuel-fired combustion devices) under the Acid Rain Program, pursuant to Title IV of the CAA, are provided in 40 CFR 72 (Ref. 8). Although this regulation primarily applies to large fossil-fuel-fired boilers including electric utility steam-generating units, certain exceptions may require an owner or operator of a CHP system to obtain an Acid Rain Permit. Applicability requirements in 40 CFR 72.6 identify affected units and affected sources subject to requirements of the Clean Air Program. In general, the following combustion devices are not considered affected units, so they typically do not need an Acid Rain Permit to operate:

- fossil-fuel-fired units that currently serve generators that do not produce electricity for sale,

- fossil-fuel-fired units that currently do not serve generators with nameplate capacities greater than $25 \mathrm{MW}(\mathrm{e})$,

- qualified facilities (see definition in Sect. 2.2),

- independent power production facilities,

- cogeneration units that supply equal to or less than one-third of their potential output capacity or equal to or less than 219,000 MWh actual electric output on an annual basis to any utility power distribution system for sale,

- $\quad$ solid waste incinerators, and

- units not owned or operated by a utility.

On August 6, 2001, EPA determined that gas turbines and waste heat-recovery components of combined-cycle gas turbine systems qualify as electric utility steam-generating units if the combinedcycle gas turbine systems supply more than one-third of their potential electric output capacity and more than $25 \mathrm{MW}$ electric output to any utility power distribution system for sale. ${ }^{40}$ Based on this determination, CHP systems of this type are subject to NSR. 
If an Acid Rain Permit is required to operate a particular affected unit or source, regulatory requirements in 40 CFR 73 (Ref. 41), 40 CFR 74 (Ref. 9), 40 CFR 76 (Ref. 42), 40 CFR 77 (Ref. 11), 40 CFR 78 (Ref. 12), 40 CFR 96 (Ref. 43), and 40 CFR 97 (Ref. 44) dealing with $\mathrm{SO}_{2}$ and $\mathrm{NO}_{\mathrm{x}}$ reduction programs may need to be addressed as part of the permitting process.

\subsubsection{State permitting programs}

Environmental regulations generally recognized that states should be responsible for taking the lead in carrying out the requirements in the CAA, because pollution control problems often require special understanding of local industries, geography, demographics, and ecosystems. States are required to develop SIPs that explain how each state will perform its duties under the law. A SIP is a collection of the regulations that a state will use to clean up polluted areas. During SIP development, states must involve the public through hearings and opportunities to comment. EPA must also approve the SIP. If a SIP is unacceptable, EPA can take over enforcing the CAA in that state. Nothing in the federal regulations prevents a state from establishing more stringent requirements provided that the requirements are consistent with the federal law.

All states are required to develop and implement an operating permit program that meets minimum federal requirements. Authorization for the operating permit program is provided in Title V, Sects. 501 to 506 of the CAA. Regulations for implementing the operating permit requirements were promulgated on July 21, 1992, and are provided in 40 CFR Part 70 (Ref. 13). Permits are required both for the operation of units (operating permits) and for the construction of new or modified units. State governments benefit from the operating permit program in several ways:

- The operating permit program provides a mechanism that state and local agencies can use to consolidate and administer provisions of the CAA, as well as their own laws.

- The program provides all state and local permitting agencies with the authority to sustain their operations using direct permit fees rather than general tax revenues.

- Improved industrial compliance with emission standards is expected to help state and local governments meet NAAQS and possibly even avoid additional local emission controls.

When required, state or local permitting authorities administer acid rain permitting programs under both Titles IV and V of the CAA. They process Acid Rain Permit applications, issue draft Acid Rain Permits for public comment, and submit proposed Acid Rain Permits to EPA for review. The permitting authorities then issue Acid Rain Permits that are approved. Each Acid Rain Permit specifies the Title IV requirements that apply to the affected source and is a portion of a larger Title V permit. An Acid Rain Permit specifies each unit's allowance allocation and $\mathrm{NO}_{\mathrm{x}}$ emission limitations (if applicable), and also specifies compliance plan(s) for the affected source.

The process for obtaining construction and operating permits for new air emissions sources depends on many factors, ${ }^{18}$ including whether the source is located in an area that does or does not meet NAAQS. Although the general procedure for obtaining construction and operating permits for CHP systems is now well-established, obtaining a permit is often time-consuming and technically complex. Extensive knowledge of the combustion systems and emission control equipment; an understanding of applicable local, state, and federal laws; and a willingness to work with permitting authorities are essential. Based on lessons learned, it is apparent to owners, operators, and regulators that the best time to control pollution is at the time the source is installed or modified. This means that new units should use the best emissions control technology that is available, and modifications to existing units should result in reduced emissions to achieve NAAQS mandated by the CAAA of 1990 (Refs. 45-47). The permitting primer under development by EPA should be a valuable resource for boiler owners and operators interested in integrating cogeneration technology into their operations. 
Guidance for environmental permitting of CHP systems in Illinois was issued in January 2003 to assist potential CHP candidates in identifying which permits are needed and understanding the various air permitting issue involved in the permitting processes. The Illinois CHP/BCHP Environmental Permitting Guidebook is divided into two volumes. Volume A-Roadmapping the Permitting Process ${ }^{34}$ details the current permitting process for CHP systems in Illinois and provides tools in the form of an emissions calculator and a step-by-step questionnaire to help navigate the permitting process. A section addressing construction permit basics describes requirements for nonattainment NSR permits and the need for LAER compliance and PSD permits in attainment areas where BACT must be employed. Volume B-Permitting Issues (A Survey and Dialogue) ${ }^{35}$ discusses specific permitting topics as well as potential opportunities to streamline the permitting process. Text in this volume is based on a survey of 20 current CHP installations and feedback from CHP developers and the Illinois Environmental Protection Agency. Although the guidebook focuses primarily on CHP facilities in Illinois that use natural gas or diesel engines, boiler owners and operators interested in understanding the fundamentals of CHP permitting may find these resources and tools helpful.

\subsubsection{Clean Water Act}

The Clean Water Act (CWA) was established in 1977 as a major amendment to the Federal Water Pollution Control Act of 1972 and was substantially modified by the Water Quality Act of 1987. This legislation established the basic structure for regulating discharges of pollutants into the waters of the United States. The 1987 amendments to the CWA significantly changed the thrust of enforcement activities. Greater emphasis is now placed on monitoring and control of toxic constituents in wastewater, the permitting of outfalls composed entirely of storm water, and the imposition of regulations governing sewage sludge disposal. These changes resulted in much stricter discharge limits and greatly expanded the number of chemical constituents monitored in the effluent.

A key feature of the CWA requires the EPA to establish effluent limitations for the amounts of specific pollutants that may be discharged by municipal sewage plants and industrial facilities. The primary method by which the act imposes limitations on pollutant discharges is the nationwide permit program established under Sect. 402 and referred to as the National Pollutant Discharge Elimination System (NPDES). Under the NPDES program any person responsible for the discharge of a pollutant or pollutants into any waters of the United States from any point source must apply for and obtain a permit.

The NPDES permitting process is the primary tool for enforcing the requirements of the NPDES Permit Program. Specific NPDES program areas applicable to industrial sources include process water discharges, nonprocess wastewater discharges, and the industrial storm water program. Before wastewater can be discharged to any receiving stream, each wastewater discharge point (outfall) must be characterized and described in a permit application. The primary regulations developed by EPA to implement the NPDES Permit Program are provided in 40 CFR 122 (Ref. 48). There are two types of NPDES permits-individual and general permits. An individual permit is a permit that is specifically tailored for an individual facility. General permits cover multiple facilities within a specific category.

Boiler blowdown, cooling tower blowdown, and cooling water represent wastewater streams commonly associated with CHP installations that must be addressed in NPDES permit applications. Guidance that may be useful in understanding the NPDES permitting process and preparing NPDES applications has been issued by EPA. ${ }^{49}$

\subsection{BENEFITS AND BARRIERS}

Cogeneration is defined as the sequential production of electrical or mechanical power and thermal energy from a single source. From a practical viewpoint, CHP systems can be of any size, and there is no limit as to the ratio in which the two types of energy are proportioned. In addition, power generated by a 
CHP system can be used on-site or exported, and the thermal energy can be used for heating, cooling, or both. Current regulations allow utilities, end-users, and third-party investors to own and operate CHP systems. This flexibility means almost limitless opportunities for applying cogeneration technology, but successful integration of cogeneration technology into new or existing boiler systems must be both technically feasible and economically viable.

Technical feasibility involves more than applying appropriate engineering principles in the design of a CHP system to meet performance criteria. It often requires obtaining construction and operating permits from authorities having jurisdiction based on compliance with environmental, energy, and safety regulations. Obtaining these permits and receiving permission to connect to the electrical grid can involve installation of special safety equipment, construction of emission control devices, modifications to existing facilities, or process changes that are not practical.

Economic viability is equally important and generally involves more complex issues that are sometimes difficult to quantify. Determining economic viability should be based on acceptance criteria established by the investor after taking into consideration realistic projections of site energy requirements and purchased energy costs. Establishing appropriate economic acceptance criteria is critical to overall project success of these reasons: ${ }^{4}$

- Artificially high end user requirements, particularly high thermal requirements, can result in overstated cogeneration operating cost savings.

- Failure to consider anticipated or potential changes in site requirements can result in a CHP system that is not properly sized for long-term viability.

- Failure to compare a CHP system serving an assumed facility heating, ventilating, and air conditioning (HVAC) system to the optimum type of HVAC system for the facility can result in illusionary savings.

- Failure to consider both incremental capital and operating costs will lead to erroneous conclusions about project viability.

Benefits and potential applications of cogeneration technology as well as barriers to implementation that can affect technical feasibility and economic viability are discussed in the following sections.

\subsubsection{Benefits and Potential Applications}

The potential for on-site power generation in the U.S. industrial sector was examined for DOE to identify opportunities for helping industry control energy costs. ${ }^{50}$ Existing on-site generation capacity in the industrial sector was estimated to be in excess of 45,000 MW, with most (42,000 MW) being CHP systems. The total remaining CHP potential is estimated at 88,000 MW including systems that export power to the electrical grid. Industries with the most CHP potential include forest products, chemicals, food, petroleum, and primary metals. Benefits of CHP include increased energy efficiency, operating cost savings, and reduced air emissions.

Compared to central utility steam generating units, CHP systems extract more useful energy from fuel and are therefore significantly more efficient. Increased efficiency translates to reduced energy consumption and associated fuels costs. The profitability of cogeneration generally results from lower cost electricity, but its success depends on using the recovered heat productively. Cogeneration is likely to be suitable in situations where there is a fairly constant and continuous thermal demand.

Although there is significant CHP potential in the industrial sector, market share is sensitive to CHP fuel price. For example, with natural gas at \$2.50/MMBtu, a 30-MW CHP system is competitive in $90 \%$ of the industrial market, but, at $\$ 4.75 / \mathrm{MMBtu}$, the competitive share drops to $43 \%$, assuming electric prices remain constant. 50 The study also revealed that a 5-MW CHP system is competitive with delivered electric prices for $37 \%$ of the industrial customers, while a $30-\mathrm{MW}$ CHP system is competitive for $68 \%$ of 
industrial customers. Because of higher equipment and installation unit costs, a relatively small 1-MW CHP reciprocating engine system is competitive for only $20 \%$ of the industrial customers. These comparisons are based on a natural gas price of \$3.50/MMBtu and the avoided boiler fuel. In summary, the study results suggest that economic benefits of CHP tend to decrease as CHP fuel price increases and tend to increase as CHP capacity increases.

Environmental benefits of cogeneration are typically characterized in terms of carbon dioxide $\left(\mathrm{CO}_{2}\right)$ emission reductions. These reductions are possible because CHP systems extract more useful energy from fuel than electric-only systems. Through increased efficiency and reduced fuel consumption, CHP systems also have the potential to reduce overall criteria pollutant emissions, including $\mathrm{NO}_{\mathrm{x}}, \mathrm{SO}_{2}$, and $\mathrm{PM}$. Although there may be a net decrease in air emissions through the application of cogeneration technology, emissions will increase from sites with existing boiler installations after CHP systems are installed. This increase in emissions, which is due to increased fuel consumption required to produce onsite power, is a permitting issue because current regulations do not allow CHP to reflect increased fuel utilization and reduced emissions inherent in the technology.

Other potential benefits provided by cogeneration technology include enhanced reliability and power quality, operational and load-management flexibility, and energy-management strategies. Depending on the site conditions, various design approaches are available for managing on-site energy production, and each mode has associated benefits. The value of these benefits depend on factors such as characteristics of the facility, operating constraints, energy use and prices, load profiles, and electric rate tariffs.

When examining the potential of cogeneration technology for a particular application, it may be necessary to consider how and when the CHP system will operate. The following modes may be used to achieve a particular strategic objective. ${ }^{4}$

- Isolated Design and Operation: In this mode, a CHP system is sized to meet the site peak with reserve allowance for short-term power transients and to operate with no connection to the electrical grid. By operating in this mode, no electricity purchases are required.

- Base-Loaded Design and Operation: In this mode, the CHP system is interconnected to the electrical grid and sized to meet the site's base-load requirements. By operating in this mode, part-load operation is avoided, no redundant capacity is required, and only supplemental power in excess of the base load is purchased from the electric utility.

- Load-Tracking Design and Operation: In this mode, the CHP system is interconnected to the electrical grid and sized to track either the site's thermal or electric load. By operating in this mode, supplemental power purchases, heat rejection, or supplemental thermal energy may be required, but both electric and thermal approaches can be designed to supply the site's peak requirements.

- Peak Shaving: In this mode, the CHP system is designed to satisfy the site's peak power requirements either by operating during the site's peak demand periods or during the utility's peak demand periods. By operating in this mode, the purchase of more expensive on-peak power is avoided, thereby decreasing the average price of power.

- Economically Dispatched: In this mode, the CHP system is operated using an approach that factors in the value of purchased power and boiler fuel costs relative to cogeneration system fuel and maintenance costs and the ability to use recoverable heat. By operating in this mode, it is possible to use microprocessor control systems to perform real-time calculations of operating costs and cost savings as a basis for making operating decisions. In addition, if the CHP system has electric capacity that exceeds the energy needs of the industrial facility, this excess capacity can be sold to the wholesale market when prices are favorable. 


\subsubsection{Barriers to Implementation}

Barriers encountered in implementing CHP projects typically involve both technical and nontechnical issues that are often interrelated. Understanding the meaning and significance of barriers that exist for a particular CHP project is key to developing effective strategies for successfully integrating cogeneration technology into new or existing boiler installations. Although barriers generally vary from one installation to another, certain barriers can be severe that project planning must be abandoned.

Many of the technical barriers to cogeneration can be related to the electric utility's responsibility to maintain the reliability, safety, and power quality of the electric power system. These barriers include

- requirements for protective relays and transfer switches,

- requirements for equipment to control power quality, and

- requirements for power flow studies and other engineering analyses.

Connecting a CHP system to the electrical grid usually involves compliance with national codes and consensus standards issued by the National Fire Protection Association (NFPA), including the National Electric Code, the Occupational Safety and Health Administration (OSHA), and local and state regulatory authorities. In addition, most electric utilities have interconnection and safety requirements that reflect company policies and operating procedures.

Utilities traditionally use mechanical relays and transfer switches that automatically isolate utility and nonutility generating equipment from the electrical grid. The primary purpose for this equipment is to provide protection against a phenomenon known as "islanding." Islanding is a safety hazard that occurs when a generating facility such as a CHP system continues to supply power to a portion of the electrical grid after the balance of the grid has been de-energized. Under certain conditions, islanding increases the risk of fire when generating equipment continues to feed a short circuit, and it increases the risk of electrocution when a person makes contact with a line that has been disconnected from the electrical grid but continues to be energized by a nonutility generator. Although mechanical relays and transfer switches are effective and reasonably efficient, the cost of installing this equipment as a prerequisite for CHP interconnection can have a negative impact on the economic viability of the project.

Power quality control is another utility concern. As discussed in Sect. 5.1, issues with power quality include voltage and frequency disturbances, voltage flicker, and waveform distortion. Utilities traditionally require the installation of over-under voltage and over-under frequency relays and other, separate, protective devices to ensure that power quality is acceptable. Some utilities accept the power quality protection offered by modern electronic equipment, but many others insist on the use of traditional, utility-approved devices.

Before allowing connection of a CHP system to the electrical grid, utilities commonly deal with local distribution system capacity constraints by conducting pre-interconnection studies. The objectives of these studies are to evaluate the potential effects of the generating facility on the affected portion of the utility system and to determine whether any upgrades or other changes are needed to accommodate the generating facility. The cost of these studies usually is passed on to the facility owner or operator. Regulatory authorities often endorse this practice under the "user pays" principle. As an additional barrier, equivalent studies for new loads that may be of equal size and impact may be addressed quite differently under long-established service tariffs.

In addition to these requirements, it may also be necessary to enter into written agreements with the utility concerning rates, metering, insurance and liability, standby power, operating schedules, and other operational issues. ${ }^{51}$ The Institute of Electrical and Electronic Engineers (IEEE) has issued a standard titled "Standard for Interconnecting Distributed Resources with Electric Power Systems." 52 It addresses a variety of technical requirements for interconnecting CHP systems to the electrical grid, but other 
important issues such as charges, tariffs, and contract rules that often vary from one utility to the next are beyond the scope of the standard. Other utility issues that can influence CHP project planning include

- Direct utility prohibition

- Tariff barriers

$\checkmark$ Demand charges

$\checkmark$ Backup tariffs

$\checkmark$ Buy-back rates

$\checkmark$ Exit fees

$\checkmark$ Uplift tariffs

$\checkmark$ Regional transmission procedures and costs

- Selective discounting

- Costs for transmission system upgrades required by the utility. These upgrades are generally based on load flow studies in which the utility asserts that the generating capability of the CHP system exceeds the capacity of the nearby transmission grid. Costs for these upgrades, which can be substantial, are passed along to the CHP system owner or operator, thus affecting the economic viability of the project.

Boiler owners and operators interested in installing a CHP system need to communicate with appropriate utility representatives at an early stage in the planning process. Some utilities require redundant mechanical relays and transfers switches even though the generating equipment includes integral electronic protection devices that comply with the IEEE standard, ${ }^{52}$ while others prohibit CHP systems from operating in parallel with the electrical grid and may even refuse to interconnect with these systems. ${ }^{51}$ Under these constraints, project planners have only two options; operate independently of the grid, or abandon the project. In some cases, CHP projects installed on the customer side of the electric meter may not be feasible due to unfavorable utility policies.

Another potential barrier that CHP project planners must face centers on obtaining construction and operating permits that comply with applicable environmental regulations. Because most CHP systems are classified as new installations irrespective of size or output, they are subject to either the nonattainment NSR program or the PSD permitting process depending on the air quality where the facility is located. Because current air quality regulations do not recognize the overall energy efficiency of CHP or credit the emissions avoided from displaced grid electricity generation, project planning is generally required to include designs for emission control systems that achieve LAER compliance or represent BACT. In addition, emissions testing and monitoring equipment for verifying compliance must be included as part of the design. The cost of emission control equipment as well as the cost of applying for construction and operating permits can be significant, especially for smaller CHP systems where the incremental cost is often disproportionately high. 


\subsection{REFERENCES}

1. Industrial and Commercial Cogeneration, Office of Technology Assessment, Congressional Board of the 98th Congress, Washington, D.C., February 1983.

2. Steam, Its Generation and Use, 40th ed., eds. S. C. Stultz and J. B. Kitto, Babcock and Wilcox, Barberton, Ohio, 1992.

3. T. R. Casten, Turning Off the Heat: Why America Must Double Energy Efficiency to Save Money and Reduce Global Warming, Prometheus Books, Amherst, New York, 1998.

4. J. A. Orlando, Cogeneration Design Guide, American Society of Heating, Refrigerating and AirConditioning Engineers, Inc., Atlanta, Georgia, 1996.

5. "Clean Air Act," U.S. Environmental Protection Agency, http://www.epa.gov/oar/caa/contents.html

6. "The Clean Air Act Amendments of 1990 Overview," U.S. Environmental Protection Agency, http://www.epa.gov/oar/caa/overview.txt

7. "National Emission Standards for Hazardous Air Pollutants from Hazardous Waste Combustors," 40 CFR 63, Subpart EEE, U.S. Environmental Protection Agency.

8. "Permits Regulation," 40 CFR 72, U.S. Environmental Protection Agency.

9. "Sulfur Dioxide Opt-Ins," 40 CFR 74, U.S. Environmental Protection Agency.

10. "Continuous Emissions Monitoring," 40 CFR 75, U.S. Environmental Protection Agency.

11. "Excess Emissions," 40 CFR 77, U.S. Environmental Protection Agency.

12. "Appeal Procedures for Acid Rain Program," 40 CFR 78, U.S. Environmental Protection Agency.

13. "State Operating Permit Programs," 40 CFR 70, U.S. Environmental Protection Agency.

14. Output-Based Regulations: A Handbook for Air Regulators, Draft Final Report, U.S.

Environmental Protection Agency, April 22, 2004.

15. "Primary and Secondary National Ambient Air Quality Standards," 40 CFR 50, U.S.

Environmental Protection Agency.

16. "Standards of Performance for Large Municipal Waste Combustors for Which Construction is Commenced After September 20, 1994, or for Which Modification or Reconstruction is Commenced After June 19, 1996," 40 CFR 60, Eb, U.S. Environmental Protection Agency.

17. "Standards of Performance for New Stationary Sources," 40 CFR 60, U.S. Environmental Protection Agency.

18. C. B. Oland, Guide to Low-Emission Boiler and Combustion Equipment Selection, ORNL/TM-2002/19, Oak Ridge National Laboratory, Oak Ridge, Tennessee, April 2002.

19. "National Emission Standards for Hazardous Air Pollutants for Stationary Reciprocating Internal Combustion Engines; Proposed Rule," Federal Register, 67, No. 244, 77830-77874, December 19, 2002.

20. "National Emission Standards for Hazardous Air Pollutants for Source Categories," 40 CFR 63, U.S. Environmental Protection Agency.

21. "Standards of Performance for Stationary Gas Turbines," Federal Register, 68, No. 71, 1799018002, April 14, 2003.

22. "National Emission Standards for Hazardous Air Pollutants for Industrial/Commercial/ Institutional Boilers and Process Heaters; Proposed Rule" Federal Register, 68, No. 8, 1660-1763, January 13, 2003.

23. National Emission Standards for Hazardous Air Pollutants for Industrial, Commercial, and Institutional Boilers and Process Heaters, OAR-2002-0058; RIN 2060-AG69, U.S. Environmental Protection Agency, Washington, D.C.

24. "National Emission Standards for Hazardous Air Pollutants for Stationary Gas Turbines; Proposed Rule," Federal Register, 68, No. 9, 1888-1929, January 14, 2003.

25. "National Emission Standards for Hazardous Air Pollutants for Stationary Gas Turbines; Final Rule," Federal Register, 69, No. 9, 10512-10548, March 5, 2004. 
26. National Emission Standards for Hazardous Air Pollutants for Stationary Combustion TurbinesProposed Delisting, OAR-2003-0189; RIN 2060-AK73, U.S. Environmental Protection Agency,

Washington, D.C.

27. National Emission Standards for Hazardous Air Pollutants for Stationary Combustion TurbinesStay Proposal, OAR-2003-0196; RIN 2060-AK73, U.S. Environmental Protection Agency, Washington, D.C.

28. National Emission Standards for Hazardous Air Pollutants for Stationary Reciprocating Internal Combustion Engines, OAR-2002-0059; RIN 2060-AG-63, U.S. Environmental Protection Agency, Washington, D.C.

29. "Permit Requirements," 40 CFR 51.165, U.S. Environmental Protection Agency.

30. "Prevention of Significant Deterioration of Air Quality Requirements," 40 CFR 51.166, U.S. Environmental Protection Agency.

31. "Prevention of Significant Deterioration of Air Quality," 40 CFR 52.21, U.S. Environmental Protection Agency.

32. "Statutory Restrictions on New Sources," 40 CFR 52.24, U.S. Environmental Protection Agency.

33. "Emission Offset Interpretative Ruling," 40 CFR 51, Appendix S, U.S. Environmental Protection Agency.

34. Illinois CHP/BCHP Environmental Permitting Guidebook, Volume A: Roadmapping the Permitting Process, prepared for the Illinois Department of Commerce and Community Affairs, U.S. Department of Energy Chicago Regional Office by the University of Illinois at Chicago-Energy Resources Center, January 23, 2003.

35. Illinois CHP/BCHP Environmental Permitting Guidebook, Volume B: Permitting Issues (A Survey And Dialogue), prepared for the Illinois Department of Commerce and Community Affairs, U.S. Department of Energy Chicago Regional Office by the University of Illinois at Chicago-Energy Resources Center, January 23, 2003.

36. "Prevention of Significant Deterioration (PSD) and Nonattainment New Source Review (NSR): Baseline Emissions Determination, Actual-to-Future-Actual Methodology, Plantwide Applicability Limitations, Clean Units, Pollution Control Projects," Federal Register, 67, No. 251, 80186-80289, December 31, 2002.

37. "Source Determinations for Combined Heat and Power Facilities under the Clean Air Act New Source Review and Title V Programs," Draft Memorandum, John S. Seitz, Director, Office of Air Quality Planning and Standards, OAR (MD-10), U.S. Environmental Protection Agency, October 15, 2001.

38. "Federal Operating Permit Programs," 40 CFR 71, U.S. Environmental Protection Agency.

39. "Approval Status of State and Local Operating Permits Programs," 40 CFR 70, Appendix A, U.S. Environmental Protection Agency.

40. "New Source Review: Applicability Determination for Cycle Gas Turbine Systems: Response letter to PM Raher," Letter from John S. Seitz, Director, Office of Air Quality Planning and Standards, U.S. Environmental Protection Agency, to Mr. Patrick M. Raher, Hogan \& Hogan L.L.P., Washington, D.C., August 6, 2001. http://www.epa.gov/ttn/oarpg/t5pgm.html

41. "Sulfur Dioxide Allowance System," 40 CFR 73, U.S. Environmental Protection Agency.

42. "Acid Rain Nitrogen Oxides Emission Reduction Program," 40 CFR 76, U.S. Environmental Protection Agency.

43. "NO $\mathrm{X}_{\mathrm{x}}$ Budget Trading Program for State Implementation Plans," 40 CFR 96, U.S. Environmental Protection Agency.

44. "Federal $\mathrm{NO}_{\mathrm{x}}$ Budget Trading Program," 40 CFR 97, U.S. Environmental Protection Agency.

45. Air Pollution Operating Permit Program Update, Key Features and Benefits, EPA/451/K-98/002, U.S. Environmental Protection Agency, February 1998.

46. F. A. Govan, Permitting Requirements for Industrial, Commercial, and Institutional Boilers, Pendent Media, Inc., Cleveland, Ohio, November 2000. 
47. M. R. Barr, "What 15,000+ Permits and Permit Modifications Have Taught Us," presented at the CIBO $\mathrm{NO}_{\mathrm{X}}$ Control XIV Conference, San Diego, California, March 13, 2001.

48. "EPA Administered Permit Programs: The National Pollutant Discharge Elimination System," 40 CFR 122, U.S. Environmental Protection Agency.

49. "Water Permitting 101," Office of Waste Management-Water Permitting, U.S. Environmental Protection Agency. http://www.epa.gov/npdes/pubs/101pape.pdf

50. T. Bryson, W. Major, and K. Darrow, Assessment of On-Site Power Opportunities in the Industrial Sector, ORNL/TM-2001/169, prepared by Onsite Energy Corp. for the Oak Ridge National Laboratory, Oak Ridge, Tennessee, September 2001.

51. R. B. Alderfer, M. M. Eldridge, and T. J. Starrs, Making Connections: Case Studies of Interconnection Barriers and Their Impact on Distributed Power Projects, NREL/SR-200-28053, National Renewable Energy Laboratory, Golden, Colorado, May 2000.

52. Standard for Interconnecting Distributed Resources with Electric Power Systems, IEEE Standard No. 1547-2003, Institute of Electrical and Electronics Engineers, New York, 2003. 


\section{PRIME MOVERS}

A prime mover is a machine or mechanism that converts energy into work. Prime movers commonly used in industrial CHP applications include steam turbines, gas turbines, microturbines, and reciprocating engines. Their primary function is to convert the energy released from fuel into mechanical energy or shaft power. This power is typically used to turn an electrical generator, but it can also be used to power other types of mechanical devices. Fuel cells represent another type of energy conversion device that is sometimes used as a prime mover in CHP applications. Although fuel cells do not produce shaft power, they are capable of converting energy to electricity through an electrochemical process that does not involve fuel combustion. To provide an understanding of their features and operational characteristics, descriptions of turbine-based and non-turbine-based prime movers are presented, and schematics of typical prime mover configurations used in CHP applications are shown.

Selecting a prime mover that is well suited for a particular CHP application requires knowledge of its design and performance characteristics as well as its potential applications. A comparison of typical parameters for steam turbines, gas turbines, microturbines, reciprocating engines, and fuel cells is summarized in Table 3.1. Additional information about each type of prime mover is presented in the following sections. Discussions about the use of prime movers in various thermodynamic cycles and their role in different CHP system configurations are presented in Chap. 7. A useful resource that provides information regarding commercially available prime movers and other types of distributed energy equipment has been assembled by the California Energy Commission (www.energy.ca.gov/distgen/equipment/equipment.html).

\subsection{STEAM TURBINES}

Steam turbines are complex pieces of rotating machinery that are custom designed for steam delivery at prescribed pressures and temperatures. They have been used as prime movers in conventional power plants and industrial CHP applications for more than 100 years and represent mature technology. Because steam turbines are capable of operating over a broad range of steam pressures, they are used in toppingcycle, bottoming-cycle, and combined-cycle CHP systems. ${ }^{1}$ Steam turbines have replaced most reciprocating steam engines for electric power generation because of their higher efficiencies and lower costs. $^{2}$

\subsubsection{Description}

A steam turbine is constructed with a stationary set of blades (called nozzles) and a moving set of adjacent blades (called buckets or rotor blades) installed within a pressure-retaining housing. The stationary nozzles accelerate the steam to high velocity by expanding it to lower pressure, while the rotating blades change the direction of the steam flow to produce torque. Steam turbines are subdivided into two principal turbine types, impulse and reaction, depending on the way they direct steam flow. ${ }^{3}$

Impulse steam turbines are rugged machines that can withstand heavy-duty service. In operation, impulse steam turbines have little or no pressure drop across the moving blades. Steam energy is transferred to the rotor entirely by the steam jets striking the moving blades. Because there is theoretically no pressure drop across the moving blades, internal clearances are large, and no balance piston is needed. These features make impulse turbines very durable.

Reaction steam turbines are somewhat more complex in their design than are impulse steam turbines. In these units, the steam expands in both the stationary and moving blades. The moving blades use the steam jet energy of the stationary blades and also act as nozzles. Reaction forces produced by the pressure drop across blades supplement the steam jet forces of the stationary blades. These combined forces produce 


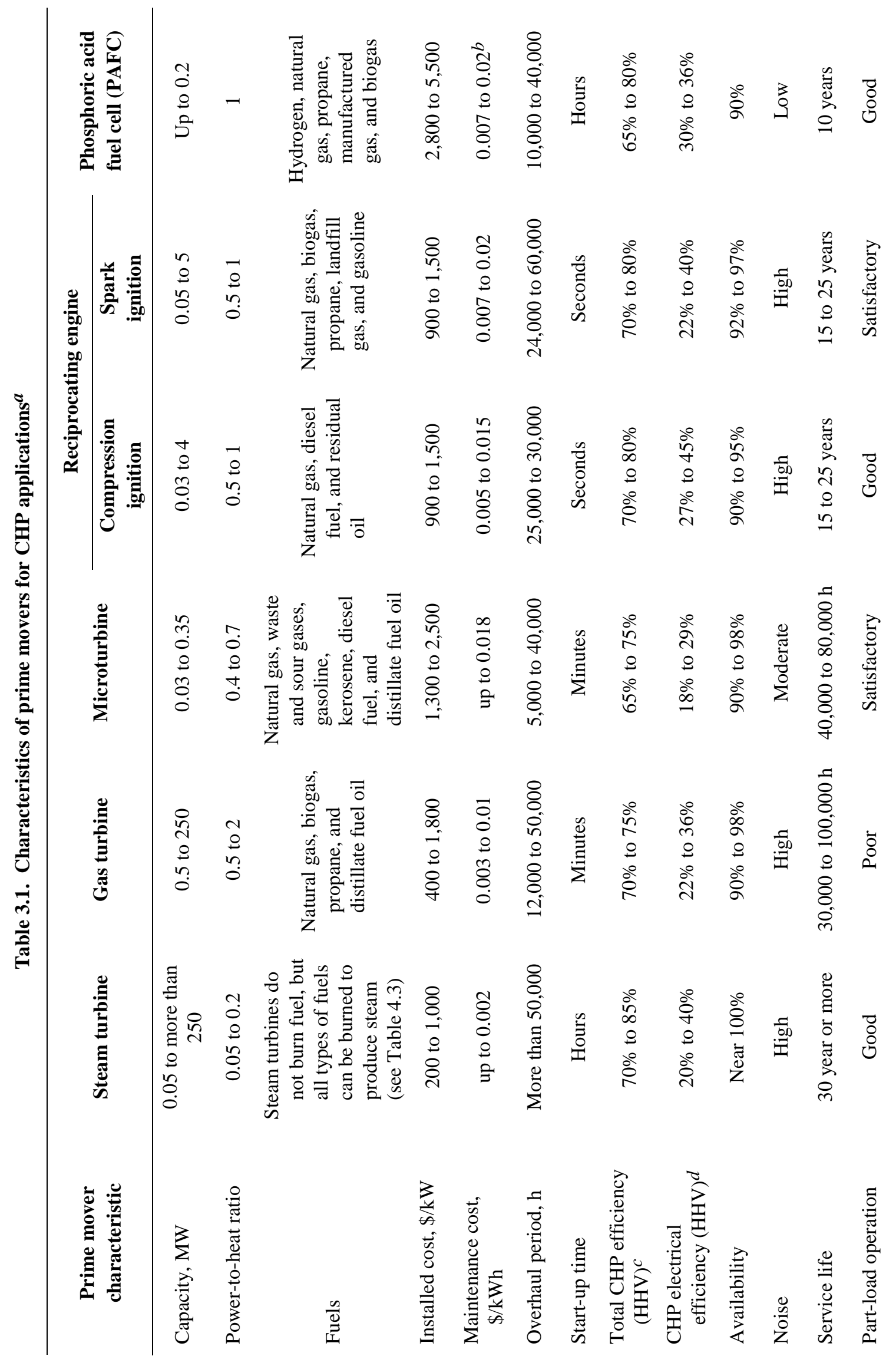




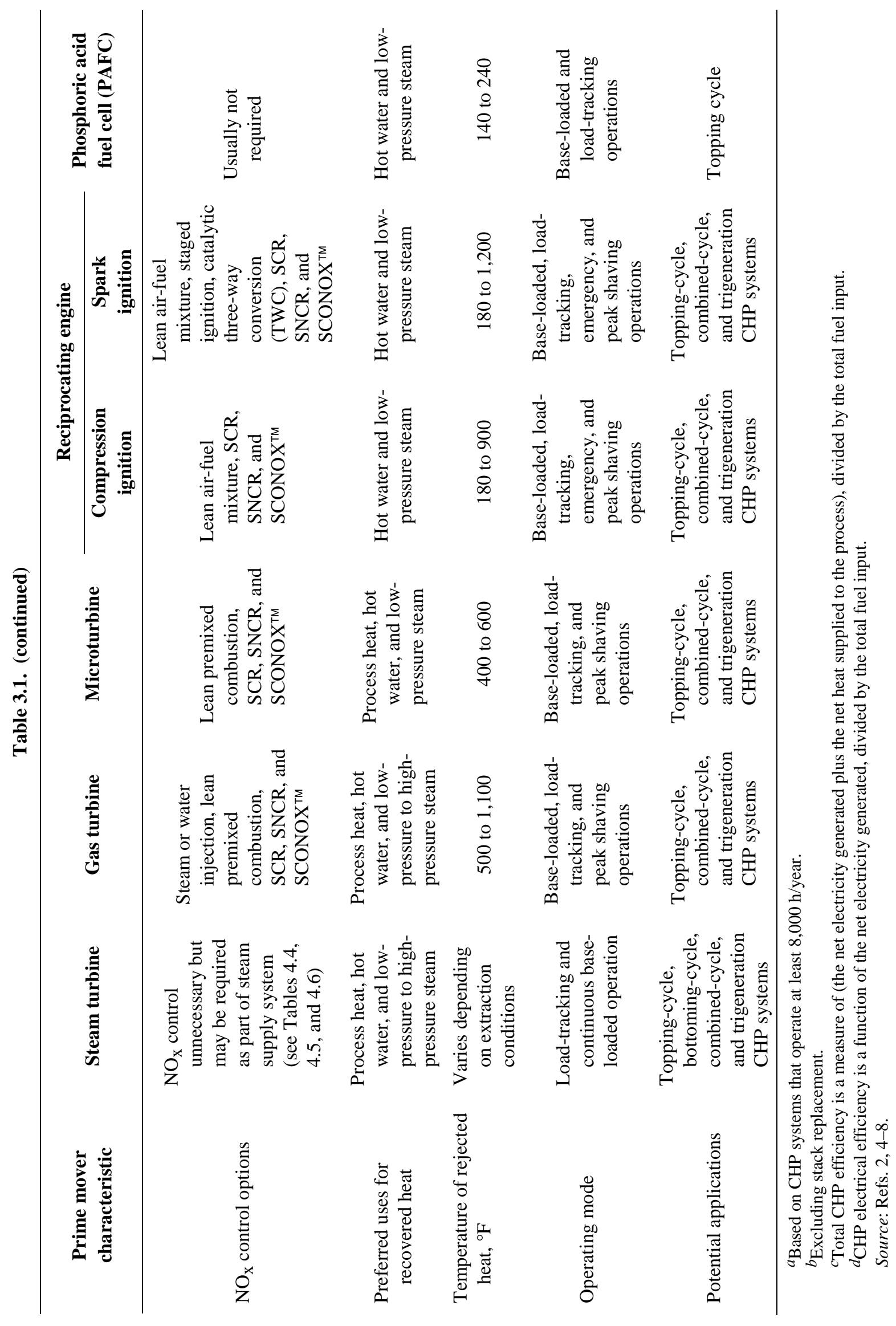


rotation. Although reaction steam turbines are widely used in Europe and the rest of the world, they are seldom used as mechanical drives in the United States.

Shaft power delivered by a steam turbine is normally used to turn an electrical generator. The amount of electric power generated depends on how much the steam pressure can be reduced while flowing through the steam turbine. In general, the higher the steam pressure supplied to the steam turbine, the greater the electric power output. Shaft power can also be used to turn pumps, compressors, and other types of rotating machinery.

High-pressure steam needed to power a steam turbine in an industrial CHP system is generally provided by a steam supply system. Most of these systems are designed to burn fossil fuels and include fuel preparation and handling equipment, a boiler or HRSG capable of producing steam, and emissions control equipment. Waste heat recovered from process furnaces, gas turbines, reciprocating engines, and other heat sources can also be used to generate steam for steam turbines.

\subsubsection{Design and Performance Characteristics}

Steam turbines for CHP systems are categorized as either (1) noncondensing (back-pressure) steam turbines or (2) condensing steam turbines. Both types work well in cogeneration applications because they offer a wide range of design flexibility to match process heating demand and performance specifications. Depending on the design, steam turbines are capable of operating over a broad range of steam pressures with inlet pressures up to 3,500 psig and exhaust pressures near absolute vacuum conditions. Size limitation is usually not an issue because steam turbines are manufactured with capacities ranging from under $100 \mathrm{~kW}$ to over $250 \mathrm{MW}$. In the multimegawatt size range, industrial and utility steam turbine designations merge, with the same steam turbine able to serve both industrial and small utility applications. ${ }^{2}$

Noncondensing steam turbines exhaust the entire flow of steam at one or more locations. The steam exhaust is either used for process applications or supplied to a lower pressure steam turbine. Typical discharge pressures range from 50 to $250 \mathrm{psig}$. Electric power generating capacity of noncondensing steam turbines is significantly reduced as the discharge or back pressure increases. For example, steam discharged at 150 psig sacrifices about half the electric power that could be generated when steam supplied to the steam turbine at $750 \mathrm{psig}$ and $800^{\circ} \mathrm{F}$ is allowed to expand to vacuum in a condenser. ${ }^{2}$ Steam turbines that exhaust the entire flow of steam at one location are known as straight noncondensing steam turbines, while steam turbines that exhaust steam at two or more locations are known as extraction noncondensing steam turbines. Both configurations are shown in Fig. 3.1.

Steam turbines that exhaust some or all of the steam flow to a condenser are known as condensing steam turbines. ${ }^{2}$ Straight condensing steam turbines exhaust the entire flow of steam to a condenser that maintains vacuum conditions at the discharge of the turbine. Units of this design are typically used as power-only utility steam turbines and are not suitable for most cogeneration applications. Condensing steam turbines with openings in the housing for exhausting a portion of the steam at some intermediate pressure before the remaining flow of steam is exhausted to a condenser are known as extractioncondensing steam turbines. This arrangement provides design flexibility and is well suited for CHP applications because extracted steam can be supplied to the process at the required conditions. Some extraction-condensing steam turbines even have multiple extraction points so that steam can be supplied at different pressures. Depending on the CHP control scheme, steam pressure from an extraction turbine may or may not be automatically regulated. When regulated, steam extraction can be controlled, allowing more steam to flow through the turbine to generate additional electricity during periods of low thermal demand. This design also allows rapid response to changes in steam demand. The configuration of an extraction-condensing steam turbine with intermediate- and low-pressure extraction ports is shown in Fig. 3.2. 


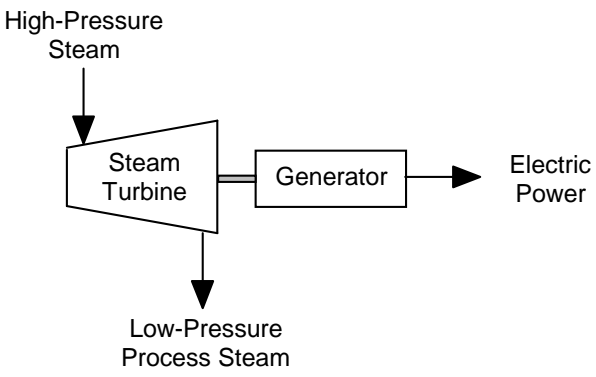

Schematic A - Straight Non-Condensing Steam Turbine

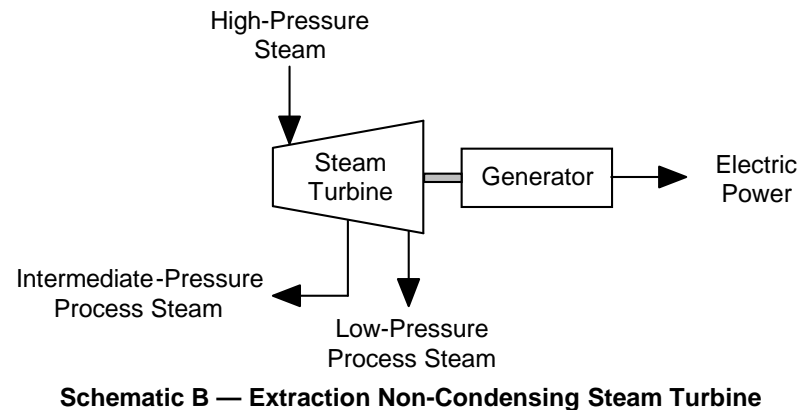

Fig. 3.1. Noncondensing or back-pressure steam turbine configurations for CHP applications.

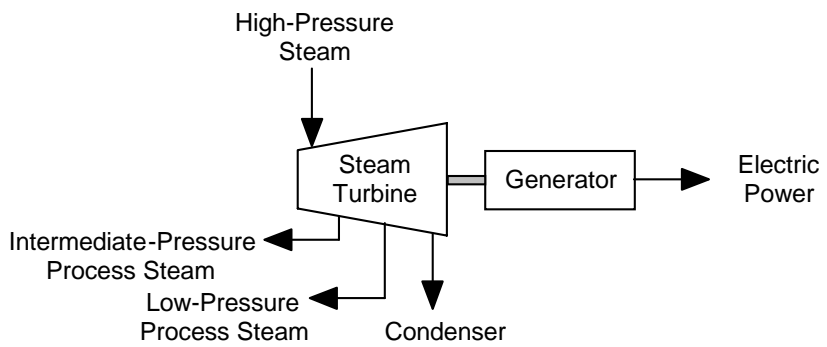

Fig. 3.2. Extraction-condensing steam turbine configuration for CHP applications.

A different type of condensing steam turbine that exhausts the entire flow of steam to a condenser is known as straight condensing steam turbine. Units of this design are typically used as power-only utility steam turbines and are not suitable for most cogeneration applications. Steam turbines that exhaust a portion of the steam at one or more locations before the remaining steam flows to a condenser are known as extraction-condensing steam turbines. ${ }^{9}$ The configuration of an extraction-condensing steam turbine with intermediate- and low-pressure extraction ports is shown in Fig. 3.2.

In selecting a steam turbine design, it is important to match CHP pressure and temperature requirements and to maximize electrical efficiency while providing the desired thermal output. Between the power-only output of a condensing turbine and the power and steam combination of noncondensing and extraction turbines, essentially any combination of power and heat can be supplied. The complexity of the CHP system usually dictates the type of steam turbine needed to achieve optimal performance. 
Codes and standards for steam turbine design, construction, performance, and installation are listed in Table 3.2.

The long history of steam turbine use has resulted in a large inventory of steam turbine stage designs. By drawing on such a large inventory, manufacturers are able to vary the flow area in the stages and adjust locations where steam is removed from the flow path between stages to satisfy almost any thermal requirements. Most steam turbines currently manufactured are multistage devices with a combination of reaction and impulse stages. In this configuration, individual blades can operate as both impulse and reaction flow devices. ${ }^{22}$ For reliability and cost reasons, steam turbine designs for industrial CHP applications are generally less complicated than steam turbines use only for electricity production. Because there are no established standards for steam turbine inlet pressures and temperatures, the following values are often used to initially design and size the steam system: ${ }^{23}$

Table 3.2. Codes and standards for steam turbines

\begin{tabular}{|c|c|c|}
\hline Designation & Title & Publisher \\
\hline API Standard 612, 5th ed. & $\begin{array}{l}\text { Petroleum, Petrochemical, and Natural Gas } \\
\text { Industries - Steam Turbines - Special- } \\
\text { purpose Applications }\end{array}$ & $\begin{array}{l}\text { American Petroleum Institute, } \\
\text { Washington, D.C. }{ }^{10}\end{array}$ \\
\hline ASME PTC 6-1996 & Performance Test Code on Steam Turbines & $\begin{array}{l}\text { American Society of Mechanical } \\
\text { Engineers, New York }{ }^{11}\end{array}$ \\
\hline $\begin{array}{l}\text { ASME PTC 6S Report-1988 } \\
\text { (Reaffirmed 1995) }\end{array}$ & $\begin{array}{l}\text { Procedures for Routine Performance Tests of } \\
\text { Steam Turbines }\end{array}$ & $\begin{array}{l}\text { American Society of Mechanical } \\
\text { Engineers, New York } 12\end{array}$ \\
\hline ASME PTC 6 Report-1985 & $\begin{array}{l}\text { Guidance for Evaluation of Measurement } \\
\text { Uncertainty in Performance Tests of Steam } \\
\text { Turbines }\end{array}$ & $\begin{array}{l}\text { American Society of Mechanical } \\
\text { Engineers, New York }{ }^{13}\end{array}$ \\
\hline ASME PTC 6A-2001 & $\begin{array}{l}\text { Test Code for Steam Turbines, Appendix A to } \\
\text { PTC } 6\end{array}$ & $\begin{array}{l}\text { American Society of Mechanical } \\
\text { Engineers, New York } 14\end{array}$ \\
\hline ASME TDP 1-1998 & $\begin{array}{l}\text { Recommended Practices for the Prevention of } \\
\text { Water Damage to Steam Turbines Used for } \\
\text { Electric Power Generation }\end{array}$ & $\begin{array}{l}\text { American Society of Mechanical } \\
\text { Engineers, New York } 15\end{array}$ \\
\hline ASME B31.1-2001 & Power Piping & $\begin{array}{l}\text { American Society of Mechanical } \\
\text { Engineers, New York } 16\end{array}$ \\
\hline ASME B31.3-2002 & Process Piping & $\begin{array}{l}\text { American Society of Mechanical } \\
\text { Engineers, New York } 17\end{array}$ \\
\hline $\begin{array}{l}\text { API Recommended } \\
\quad \text { Practice 574, 2nd ed. }\end{array}$ & $\begin{array}{l}\text { Inspection Practices for Piping System } \\
\text { Components }\end{array}$ & $\begin{array}{l}\text { American Petroleum Institute, } \\
\text { Washington, D.C. } 18\end{array}$ \\
\hline $\begin{array}{l}\text { NEMA Standards } \\
\text { Publication } \\
\text { No. SM 23-1991 (R1997, } \\
\text { R2002) }\end{array}$ & Steam Turbines for Mechanical Drive Service & $\begin{array}{l}\text { National Electrical } \\
\text { Manufacturers Association, } \\
\text { Rosslyn, Virginia } 19\end{array}$ \\
\hline $\begin{array}{l}\text { NEMA Standards } \\
\text { Publication } \\
\text { No. SM 24-1991 (R1997, } \\
\text { R2002) }\end{array}$ & $\begin{array}{l}\text { Land-Based Steam Turbine Generator Sets } \\
0-33,000 \mathrm{~kW}\end{array}$ & $\begin{array}{l}\text { National Electrical } \\
\text { Manufacturers Association, } \\
\text { Rosslyn, Virginia } 20\end{array}$ \\
\hline $\begin{array}{l}\text { IEEE Standard No. 1547- } \\
2003\end{array}$ & $\begin{array}{l}\text { Standard for Interconnecting Distributed } \\
\text { Resources with Electric Power Systems }\end{array}$ & $\begin{array}{l}\text { Institute of Electrical and } \\
\text { Electronics Engineers, New } \\
\text { York }^{21}\end{array}$ \\
\hline
\end{tabular}


- 400 psig at $750^{\circ} \mathrm{F}$,

- 600 psig at $825^{\circ} \mathrm{F}$,

- 850 psig at $900^{\circ} \mathrm{F}$, and

- 1,250 psig at $950^{\circ} \mathrm{F}$ or $1,000^{\circ} \mathrm{F}$.

Steam turbines that power electrical generators operate at a single speed. A governor is used to control the speed within set limits over the total load range. When used to drive other types of rotating machinery, steam turbines are often required to operate over a range of speeds. For slower speed equipment like reciprocating compressors and pumps, a gearbox can be coupled to the steam turbine shaft to achieve the necessary speed reduction. Speed-modifying equipment for steam turbine applications often use spur gear units, epicyclic gears, clutches, or hydroviscous drives to accommodate the required speed of the driven equipment. ${ }^{3}$ State-of-the-art control systems use electronic speed and pressure sensors, digital processing and logic, and hydraulically operated valves to achieve optimum operating performance.

Electrical generators and steam turbines are often assembled and supplied as a single package ready for field installation. When considering steam turbine options, it is important to realize that turbinegenerator packages can be very heavy and may require construction of special foundations and pedestal supports with adequate structural capacity. It is also important to recognize that construction of the highpressure, high-temperature steam pipes that connect steam turbines to boilers generally require engineering and mechanical expertise to realize code compliance.

During operation, enclosed steam turbine sound levels are generally 85 dBA or less. ${ }^{22}$ In many cases, noises emanating from pipes, pumps, valves, fuel-handling systems, and boilers are a greater concern.

\subsubsection{Efficiency}

Efficiency is one of the most frequently used terms in thermodynamics. It indicates how well an energy conversion or transfer process is accomplished. Thermodynamic efficiency is a term used for expressing efficiency for devices that operate in cycles or for individual components that operate in processes. The thermal efficiency of a cycle is the ratio of output energy to input energy. Because the meaning of efficiency can sometimes be confusing, terms used in this discussion to describe different types of efficiency are defined as follows: ${ }^{2}$

Isentropic efficiency: a comparison of the actual work output of a machine compared to the ideal, or isentropic, output. It is a measure of the effectiveness of extracting work from the expansion process and is used to determine the outlet conditions of the steam from a steam turbine.

CHP electrical efficiency: a measure of the amount of fuel energy converted into electricity. In numerical terms, CHP electrical efficiency is a function of the net electricity generated and the total fuel input expressed as follows:

Net electricity generated/Total fuel input

Total CHP efficiency: a measure of the net electricity generated, the net heat supplied to the process, and the total fuel input expressed as follows:

(Net electricity generated + Net heat supplied to process)/Total fuel input

Effective electrical efficiency: a function of the steam turbine electric power output and the total fuel input expressed as follows: 
Steam turbine electric power output/[Total fuel input - (Steam to process/Boiler efficiency)]

Boiler efficiency: a value that characterizes the amount of heat captured by the boiler or HRSG and transferred to the water compared to the heat input. Boiler efficiency is a function of boiler losses and combustion losses.

The isentropic efficiency of a steam turbine is a measure of how effectively the turbine extracts work from steam. It refers to the ratio of work actually generated by the turbine to that generated by a perfect turbine with no internal losses using steam at the same inlet conditions and discharging to the same downstream pressure (actual enthalpy drop divided by the isentropic enthalpy drop). Steam turbine efficiency is a function of turbine blade geometry, flow, and speed. It is generally not affected by steam inlet temperatures or part-load operation.

Backpressure steam turbines yield the highest thermodynamic efficiency when $100 \%$ of the exhaust steam is used for thermal process applications. Multistage (moderate to high-pressure ratio) steam turbines have thermodynamic efficiencies that vary from $65 \%$ for small (under $1,000-\mathrm{kW}$ ) units to over $90 \%$ for large industrial and utility sized units. Small, single-stage steam turbines can have thermodynamic efficiencies as low as $50 \%$. When a steam turbine exhausts to a CHP application, the thermodynamic efficiency of the turbine is not as critical as in a power-only condensing mode because the majority of the energy not extracted by the steam turbine satisfies the thermal load. In power-only applications, the energy in steam turbine exhaust is lost in the condenser.

For standard steam turbine power plants, electrical generating efficiency varies from a high of about $41 \%$ for large, electric utility plants designed for the highest practical annual capacity factor, to under $10 \%$ for small, simple plants that make electricity as a byproduct of delivering steam to process applications or district heating systems. Efficiency of electricity generation by steam turbines increases with increasing inlet temperature and pressure ratio, and with size up to about $30 \mathrm{MW}$ (Ref. 24). In CHP applications, the amount of fuel converted into electricity by a steam turbine (CHP electrical efficiency) is generally low because the primary use of the fuel energy is to produce large amounts of steam to meet process demands. Although CHP electrical efficiency is low, the effective electrical efficiency of steam turbine systems is generally high, because almost all the energy difference between the high-pressure boiler or HRSG output and the lower pressure turbine output is converted to electricity. This means that total steam turbine CHP system efficiency generally approaches the boiler efficiency, which typically ranges from $70 \%$ to $85 \%$ depending on boiler type and age, fuel, duty cycle, application, and steam conditions. $^{2}$ A large steam turbine topping-cycle CHP system with an efficient watertube boiler, economizer, and preheater can achieve a total CHP efficiency that exceeds $90 \%$ (Ref. 23).

\subsubsection{Capital cost}

Steam turbine prices vary significantly depending on the extent of competition for units of desired size, inlet and exit steam conditions, rotational speed, and standardization of construction. Price quotes are usually provided for an assembled steam turbine and electrical generator package with the generator accounting for $20 \%$ to $40 \%$ of the total price.

Installation costs for new steam turbine and boiler systems generally range from $\$ 800$ to $\$ 1,000 / \mathrm{kW}$, but the incremental cost of adding a steam turbine to an existing boiler system or to an existing combinedcycle plant is approximately $\$ 200$ to $\$ 800 / \mathrm{kW}$ (Refs. 2 and 4). Modifications to the steam supply system

to accommodate the installation of a steam turbine can also add to the overall cost. In situations where there is a need to quickly add generating capacity, steam turbines may not be the preferred option. There can be a relatively long lead time between the time the steam turbine is ordered and the time it begins operating. 


\subsubsection{Availability}

The availability of steam turbines is typically quite high, with a forced outage rate of $2 \%$ or less. When a steam turbine is operated properly, maintained regularly, and supplied with treated boiler water, its service life can exceed 30 years. In operation, steam turbines require long warm-up periods to minimize thermal expansion stresses and component wear. Unlike reciprocating engines and gas turbines, steam turbines do not require auxiliary starting systems, but large steam turbines may take hours to warm up properly. After warm up, steam turbines usually provide satisfactory service when they operate continuously for extended periods. Optimum performance is generally achieved at approximately $95 \%$ of the rated load. 22

\subsubsection{Maintenance}

Steam turbines are very reliable and have a long history of satisfactory performance. Many only require overhauls after several years of productive service. ${ }^{1}$ Routine maintenance is generally limited to making sure that all fluids (steam flowing through the turbine and oil for the bearings) are clean and at the proper temperature. Maintaining proper feedwater and steam chemistry is also necessary to minimize both corrosion and erosion problems. These practices are key to assuring long-term, reliable performance.

A potential maintenance issue with steam turbines relates to solids carryover from the boiler that deposit on turbine nozzles and other internal parts. These deposits, which may or may not be soluble in water, can degrade turbine efficiency and adversely affect power output. Approaches often taken to dislodge solid deposits include applying manual removal techniques, cracking the deposits by shutting the turbine off and allowing it to cool, and washing the turbine with water while it is running to remove water soluble deposits. Other maintenance issues include inspecting auxiliaries such as lubrication pumps, coolers, and strainers and checking safety devices such as the operation of overspeed controls. Cyclic operation and operation at low loads can also create stress- and corrosion-fatigue problems. Steam turbine maintenance costs are relatively low, typically around $\$ 0.002 / \mathrm{kWh}$ (Refs. 2 and 24).

\subsubsection{Heat recovery}

The amount and quality of recovered heat from a steam turbine is a function of the entering steam conditions and the design of the steam turbine. Medium- and low-pressure steam exhausted from a steam turbine can be used directly in a process, converted to other forms of useful thermal energy, or used to power other steam turbines. Waste heat discharged or extracted from a steam turbine in the form of lowpressure steam can be used to produce hot water, power an absorption chiller, or recharge desiccants. Replacing pressure-reducing valves with steam turbines is a very effective way to recover waste heat and thereby improve the overall energy efficiency of a CHP system.

\subsubsection{Fuels and emissions}

Steam turbines are not designed to burn fuel. They rely on boilers or other steam-generating equipment to deliver the required amount of high-pressure steam. This separation of functions enables steam turbines to operate with an enormous variety of fuels while emitting no regulated air pollutants.

Although high-pressure steam can be produced by the combustion of solid, liquid, or gaseous fuel, many factors must be considered when selecting a fuel and the combustion equipment that will convert the chemical energy in the fuel into steam. Fuel price, fuel availability, equipment cost, and emissions are key factors that can affect the selection process, but the role of legal, political, environmental, and technical issues in the decision-making process should not be ignored. ${ }^{25}$ Because fuel cost is critically important to CHP economic viability, new or existing boiler installations that burn inexpensive or waste 
fuels such as biomass, refuse-derived fuel (RDF), tire-derived fuel (TDF), or municipal solid waste (MSW) represent cogeneration opportunities with higher than average potential for economic success. A list of fuels commonly burned to generate steam needed to power steam turbines is presented in Table 4.3.

\subsubsection{Potential Applications}

Steam turbines are well suited for medium- and large-scale industrial CHP applications where inexpensive fuels such as coal, biomass, various solid wastes and byproducts (e.g., wood chips, TDF, RDF, SMW, etc.), residual oil, and refinery gases are available. Adding a steam turbine and electrical generator package to an existing boiler installation that uses inexpensive fuels is often an economically attractive option, especially when the boiler is already capable of providing more than enough highpressure steam to satisfy the thermal demand. In situations where an existing boiler produces only lowpressure steam, it may not be feasible to use a steam turbine to generate electricity unless the lowpressure boiler is replaced or modified for higher pressure service. Because optimum steam turbine performance occurs when the turbine operates continuously, steam turbines are used most effectively for base-load applications.

An important option for applying cogeneration technology to a new or existing boiler installation involves the use of noncondensing or back-pressure steam turbines as a substitute for pressure-reducing valves. Such an arrangement is shown in Fig. 3.3. Steam turbines used for this topping-cycle application are capable of providing pressure regulation while also producing electricity. Although back-pressure steam turbine topping-cycle CHP systems exhibit very high total energy efficiency, they provide little flexibility in directly matching electrical output to electrical requirements because steam flow through the turbine is controlled by the thermal load. As an alternative, excess steam can be vented to the atmosphere, but this practice is very inefficient and results in the waste of treated boiler water. ${ }^{22}$ Straight steam condensing turbines offer no opportunity for topping-cycle CHP applications, but they are suitable for use in bottoming-cycle CHP systems. Steam generated from process waste heat can be most efficiently used by full-condensing steam turbines when there is no other use for low-pressure steam. ${ }^{23}$

Boiler owners and operators who are interested in integrating cogeneration technology into an existing boiler installation should consider the addition of steam turbines, especially if their steam requirements are relatively large compared to their power needs. To help make the decision, it is important to verify that the existing boiler is capable of supplying additional steam at the required pressure and temperature needed to operate the turbine-generator set. In addition, the remainder of the steam supply system must be able to accommodate the increased flow rate of lower quality steam exhausted by the steam turbine. For favorable situations, the decision involves only the added capital cost of the steam turbine, its electrical generator, controls, and electrical interconnection, with the balance of plant already in place. In addition, the remainder of the steam supply system must be able to accommodate the subsequent changes in steam flow.

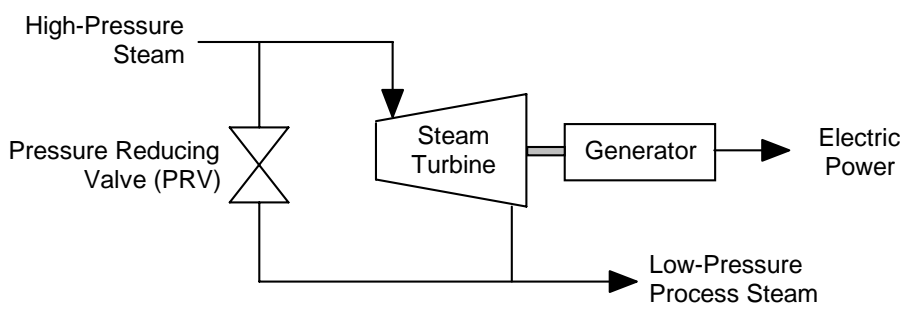

Fig. 3.3. Back-pressure steam turbine arrangement that functions as a low-pressure steam source. 


\subsection{GAS TURBINES}

Gas turbines have been used for electric power generation since the 1930s. Also known as combustion turbines, gas turbines are currently the preferred choice for most new power plants in the United States. ${ }^{6}$ Besides being economical, gas turbines that fire natural gas can be designed to release very low levels of $\mathrm{NO}_{\mathrm{x}}$. Natural-gas-fired gas turbines are also being used to repower existing power plants, thereby allowing owners to raise output and increase overall efficiency without constructing a new plant. ${ }^{26}$

In industrial CHP applications, gas turbines are used as prime movers for generating electricity in both topping-cycle and combined-cycle systems. To effectively use the waste heat, thermal energy that is rejected from gas turbines as a continuous stream of high-temperature exhaust gases is recovered and used in process heating applications to achieve overall system efficiencies of $70 \%$ to $80 \%$. The recovered heat is primarily used to produce steam or to increase the temperature of boiler feedwater, but it can also be used for direct heating and other processing applications.

\subsubsection{Description}

Basic elements of a gas turbine are the air compressor, combustion chamber, and turbine. In operation, fresh air is drawn in by the compressor and forced into the combustion chamber. Inside the combustion chamber, the compressed air mixes with the fuel, and combustion occurs. During combustion, the chemical energy in the fuel is released to produce the high-temperature combustion products needed to power the gas turbine. As hot combustion products are produced, they flow through the gas turbine before being discharged to the atmosphere.

Mechanical energy used by the air compressor is supplied by the turbine with the remainder of the energy being available for other forms of useful work. Work required by the air compressor is typically as much as half, but may be up to two-thirds, of the power developed by the gas turbine. Remaining mechanical energy is normally used to turn an electrical generator, but it can also be used as the power source for other types of rotating machinery such as pumps, compressors, and fans. Gas turbines are suitable for producing electricity for either base-loaded or peaking applications.

Two basic types of gas turbines are used for stationary power production: (1) aeroderivative gas turbines are adapted from their jet engine counterparts, and (2) industrial or frame gas turbines are used exclusively for stationary power generation. ${ }^{6}$ Both designs have been used successfully in CHP applications because of their low initial cost, high availability, low maintenance costs, fuel-switching capabilities, high-quality heat, and high efficiency in large sizes. ${ }^{22}$

Aeroderivative gas turbines are lightweight and thermally efficient, but they are usually more expensive than gas turbines that are designed and built exclusively for stationary applications. When modified for stationary use, aeroderivative gas turbines are generally capable of faster start-ups and more rapid response to changing loads. The largest aeroderivative gas turbines available for stationary power production have generating capacities that range from 40 to $50 \mathrm{MW}$. Because many of these gas turbines operate with compression ratios in the range of 30-to-1, they require a high-pressure external fuel gas compressor.

Industrial or frame gas turbines are commercially available in the 1- to 250-MW capacity range and are used exclusively for stationary power generation. Although industrial gas turbines are typically less efficient and much heavier than aeroderivative turbines, they are better suited for continuous base-load operation with longer inspection and maintenance intervals. Compression ratios for industrial gas turbines are generally more modest ranging up to 16-to-1, and they often do not require an external fuel gas compressor. From a cost viewpoint, industrial gas turbines are generally less expensive than comparably sized aeroderivative gas turbines. 
Gas turbines are also classified as either single-shaft or split-shaft or two-shaft models. ${ }^{23}$ Singleshaft models have the compressor, gas-producer turbine, and power turbine on the same shaft. They are used primarily when a constant speed is required for electric power generation or when starting torque is low. Two-shaft models have the air compressor and hot gas generator section on one shaft and the power output section on a second shaft. They are used when high torque starting is required and when variable speed at full load is necessary.

Manufacturers generally mount the gas turbine on the same base as the electrical generator. A stepdown gearbox is often needed to reduce the high shaft speed of the gas turbine to the specified operating speed of the generator. In operation, gas turbines are very noisy. For this reason, they are generally housed in an acoustic enclosure that provides the required level of noise attenuation.

\subsubsection{Design and Performance Characteristics}

Most gas turbines used in CHP applications are designed to operate in an open-cycle configuration with fresh combustion air drawn in through the compressor and exhaust gases discharged to the atmosphere. Typical exhaust gas temperatures are up to or slightly above $1,000^{\circ} \mathrm{F}$ (Ref. 1$)$. In this arrangement, the blades and other internal components are exposed to the hot exhaust gases and the associated products of combustion. Exposure to the exhaust gas stream makes open-cycle gas turbines susceptible to high-temperature corrosion and erosion problems. To minimize damage, most gas turbines are designed to burn clean fuel such as natural gas that is free from potentially harmful impurities. Although firing of fuels other than natural gas is feasible, it is usually not practical unless the combustion system includes auxiliary fuel cleaning equipment. Fuel selection is also important because the energy in the fuel influences gas turbine performance. For example, the hot exhaust gases leaving the combustion chamber when using a low calorific value fuel such as landfill gas will not be the same as when operating on natural gas because the mass flow through the gas turbine determines the power output. To help improve gas turbine efficiency, a heat exchanger known as a recuperator can be added to the system. Its purpose is to recover thermal energy from the exhaust gas stream and use it to preheat the pressurized combustion air that discharges from the compressor. Although recuperators improve gas turbine efficiency, the amount of rejected heat available for process applications is lower because the recuperator reduces the exhaust gas temperature to about $600^{\circ} \mathrm{F}$ or less. ${ }^{1}$ Configurations of open-cycle gas turbine systems with and without recuperators are shown in Fig. 3.4.

In closed-cycle gas turbine systems, the working fluid that flows through the turbine housing is typically either helium or air, not the hot combustion products. This fluid circulates in a closed loop that connects the gas turbine to a heat exchanger located within the combustion chamber. The function of this heat exchanger is to transfer thermal energy from the hot combustion products to the working fluid. By circulating an uncontaminated working fluid through the gas turbine, the potential for turbine blade wear and damage are significantly reduced because the blades and other vulnerable components are isolated from the high-temperature exhaust gas stream. This arrangement also permits greater fuel flexibility, making it possible to fire gas turbines with a variety of fuels other than natural gas. To improve efficiency, a regenerator can be added to a closed-cycle system to recover heat from the exhaust gas stream and use it to increase the temperature of the combustion air. Configurations of closed-cycle gas turbine systems with and without regenerators are shown in Fig. 3.5.

Although it may be technically feasible to include a heat exchanger as part of the combustion chamber, long-term durability in the high-temperature and severe service environment represents a significant design challenge. Currently, there are no commercially available gas turbines suitable for closed-cycle operations. 


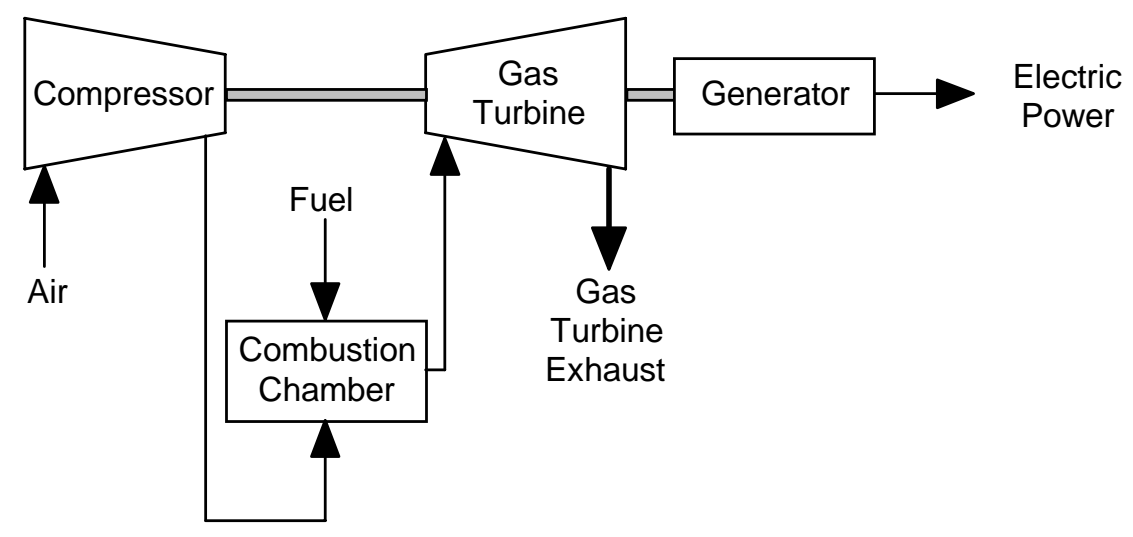

Open-Cycle Gas Turbine without Recuperator

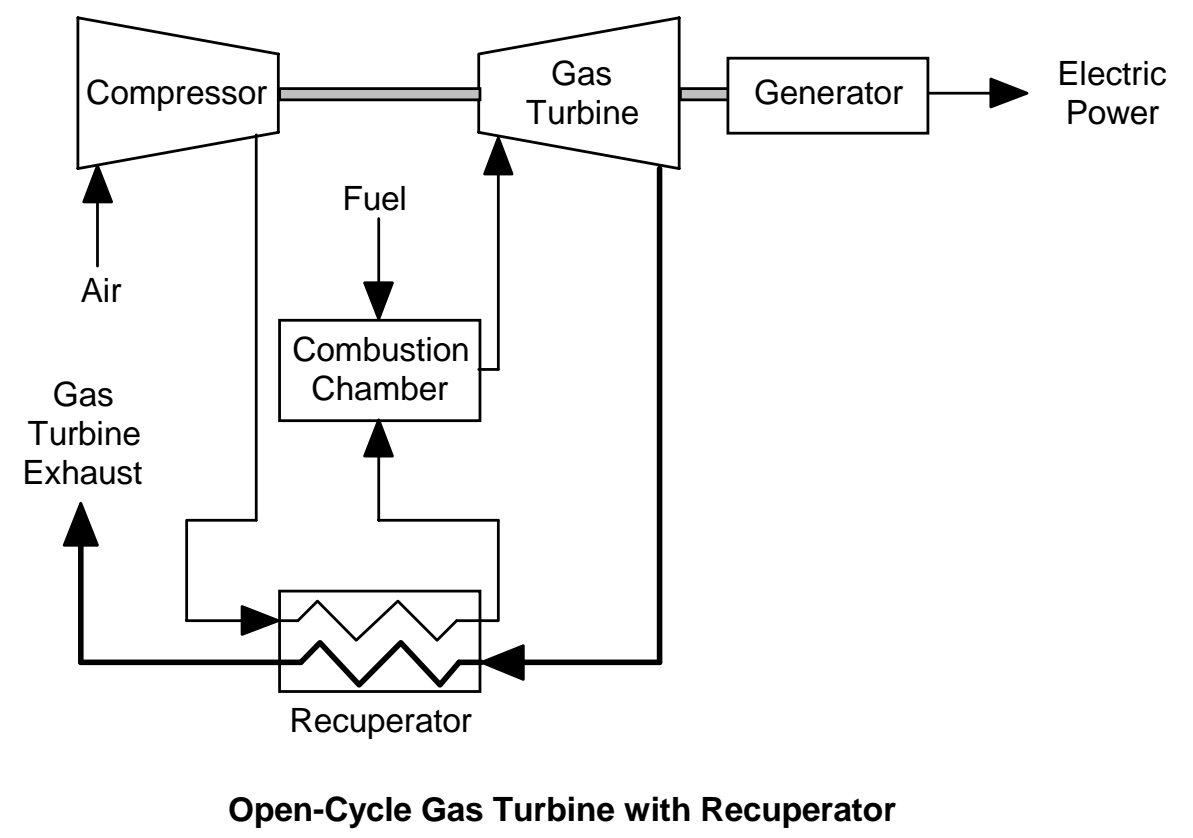

Fig. 3.4. Open-cycle gas turbine configurations for CHP applications. 


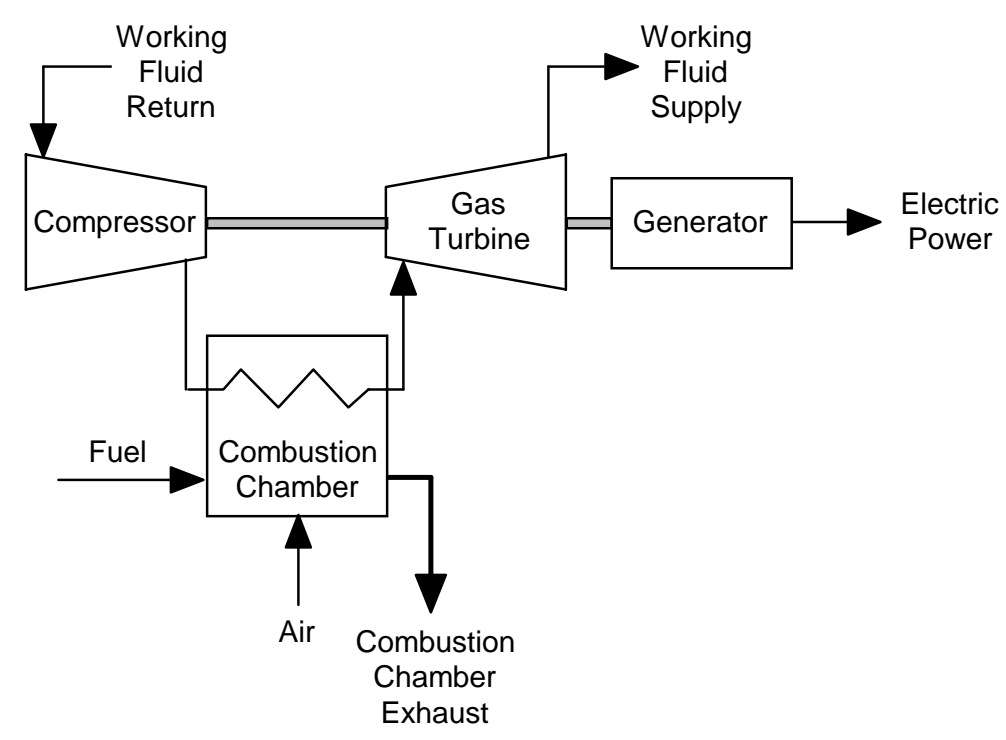

Closed-Cycle Gas Turbine without Regenerator

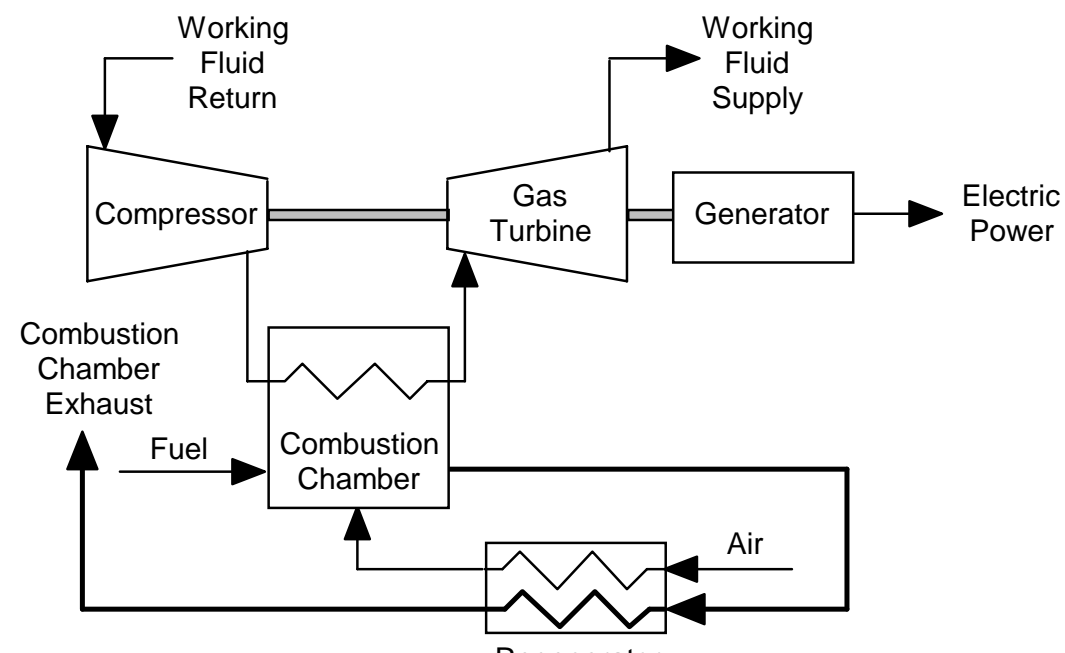

Regenerator

Closed-Cycle Gas Turbine with Regenerator

Fig. 3.5. Closed-cycle gas turbine configurations for CHP applications.

Gas turbines are used primarily in CHP topping-cycle systems either separately or as part of combined-cycle systems to produce electricity and to generate heat for process applications. Although the hot exhaust gases can be used directly for process heating applications, gas turbine CHP systems generally include either a fired or unfired HRSG or an ICI boiler to recover the rejected heat. Effective heat recovery is necessary for efficient gas turbine operation.

To promote effective communications between gas turbine purchasers and manufacturers about technical issues related to stationary open-cycle, closed-cycle, semiclosed-cycle, and combined-cycle gas 
turbine systems, the B133 Standards Committee of the American Society of Mechanical Engineers (ASME) has developed a series of standards applicable to gas turbine procurement. ${ }^{27-37}$ The purpose of the standards is to facilitate preparation of, and responses to, gas turbine procurement specifications. Specific system configurations covered by the standards include

- simple cycle, single-shaft gas turbines;

- regenerative cycle, single-shaft gas turbines;

- $\quad$ simple cycle, single-shaft gas turbines (i.e., with separate power turbine);

- intercooled and reheat cycle (compound type), multishaft gas turbine with load coupled to lowpressure shaft;

- $\quad$ single-shaft gas turbine with air bleed and hot gas bleed;

- $\quad$ single-shaft closed-cycle gas turbine;

- $\quad$ single-shaft type, combined cycle; and

- multishaft type, combined cycle (configuration with two turbines and one steam turbine).

Additional codes and standards applicable to design, construction, performance, and installation of gas turbine systems are listed in Table 3.3.

\subsubsection{Efficiency}

To deliver maximum power at optimum efficiency, the turbine needs to be supplied with gas at the highest practical temperature. This is important because the power output is proportional to the absolute temperature of the gas that passes through the turbine. Raising the inlet temperature increases gas turbine efficiency especially when the difference between the inlet and exhaust temperatures increases. The temperature of the combustion air also affects gas turbine efficiency. As the air temperature decreases, the air density increases, resulting in increased mass flow and thus higher efficiency. Various techniques, such as evaporative cooling, water spraying, and mechanical cooling, can be used to reduce the temperature of the combustion air.

Current state-of-the-art gas turbine designs have inlet temperatures that approach or sometimes exceed $2,400^{\circ} \mathrm{F}$ (Ref. 1). Achieving meaningful efficiency improvement by increasing the inlet temperature beyond this value is not very practical because materials suitable for continuous service above this temperature are either unavailable or prohibitively expensive.

Reducing the exhaust gas temperature is a more practical way to improve gas turbine efficiency. This can be accomplished by installing a recuperator in the exhaust gas stream. A recuperator uses heat recovered from the exhaust gases to increase the temperature of the air that discharges from the compressor, thereby reducing the amount of fuel required to produce a specific inlet temperature. Depending on gas turbine operating parameters, installing a recuperator can increase efficiency from $30 \%$ to $40 \%$ (Ref. 6).

Although use of a regenerator is an effective way to reduce fuel consumption, significant engineering challenges are associated with its design, construction, and in-service performance in the high-temperature exhaust gas environment. Some of the more important technical issues are discussed in Sect. 4.1.3. Regenerators are also expensive, and their cost can normally only be justified when the gas turbine operates for a large number of full-power hours per year and the cost of fuel is relatively high. ${ }^{6}$

Another way to improve gas turbine efficiency is to operate the air compressor with inlet air flow at as low a temperature as possible. Because ambient conditions influence gas turbine performance, manufacturers normally specify capacity and performance under standardized conditions of $59^{\circ} \mathrm{F}$ and 
Table 3.3. Codes and standards for gas turbines

\begin{tabular}{|c|c|c|}
\hline Designation & Title & Publisher \\
\hline API Standard 616, 4th ed. & $\begin{array}{l}\text { Gas Turbines for the Petroleum, Chemical, } \\
\text { and Gas Industry Services }\end{array}$ & $\begin{array}{l}\text { American Petroleum Institute, } \\
\text { Washington, D.C. } 38\end{array}$ \\
\hline $\begin{array}{l}\text { API Recommended } \\
\text { Practice 11PGT, } 1 \text { st ed. }\end{array}$ & $\begin{array}{l}\text { Recommended Practice for Packaged } \\
\text { Combustion Gas Turbines }\end{array}$ & $\begin{array}{l}\text { American Petroleum Institute, } \\
\text { Washington, D.C. }{ }^{39}\end{array}$ \\
\hline $\begin{array}{l}\text { ASME PTC 4.4-1981 } \\
\text { (Reaffirmed 2003) }\end{array}$ & $\begin{array}{l}\text { Performance Test Code on Gas Turbine Heat } \\
\text { Recovery Steam Generators }\end{array}$ & $\begin{array}{l}\text { American Society of Mechanical } \\
\text { Engineers, New York }{ }^{11}\end{array}$ \\
\hline ASME PTC 22-1997 & Performance Test Code on Gas Turbines & $\begin{array}{l}\text { American Society of Mechanical } \\
\text { Engineers, New York } 40\end{array}$ \\
\hline ASME B31.1-2001 & Power Piping & $\begin{array}{l}\text { American Society of Mechanical } \\
\text { Engineers, New York } 16\end{array}$ \\
\hline ASME B31.3-2002 & Process Piping & $\begin{array}{l}\text { American Society of Mechanical } \\
\text { Engineers, New York } 17\end{array}$ \\
\hline ASME B31.8-2000 & $\begin{array}{l}\text { Gas Transmission and Distribution Piping } \\
\text { Systems }\end{array}$ & $\begin{array}{l}\text { American Society of Mechanical } \\
\text { Engineers, New York } 41\end{array}$ \\
\hline ASME 3977 1-2000 & $\begin{array}{l}\text { Gas Turbines: Procurement, Part 1: General } \\
\text { Introduction and Definitions }\end{array}$ & $\begin{array}{l}\text { American Society of Mechanical } \\
\text { Engineers, New York }{ }^{27}\end{array}$ \\
\hline ASME 3977 2-2000 & $\begin{array}{l}\text { Gas Turbines: Procurement, Part 2: Standard } \\
\text { Reference Conditions and Ratings }\end{array}$ & $\begin{array}{l}\text { American Society of Mechanical } \\
\text { Engineers, New York } 28\end{array}$ \\
\hline $\begin{array}{l}\text { ANSI B133.3-1981 } \\
\text { (Reaffirmed 1994) }\end{array}$ & $\begin{array}{l}\text { Procurement Standard for Gas Turbine } \\
\text { Auxiliary Equipment }\end{array}$ & $\begin{array}{l}\text { American Society of Mechanical } \\
\text { Engineers, New York } 29\end{array}$ \\
\hline $\begin{array}{l}\text { ANSI B133.4-1978 } \\
\text { (Reaffirmed 1997) }\end{array}$ & Gas Turbine Control and Protection Systems & $\begin{array}{l}\text { American Society of Mechanical } \\
\text { Engineers, New York } 30\end{array}$ \\
\hline $\begin{array}{l}\text { ANSI B133.5-1978 } \\
\text { (Reaffirmed 1997) }\end{array}$ & $\begin{array}{l}\text { Procurement Standard for Gas Turbine } \\
\text { Electrical Equipment }\end{array}$ & $\begin{array}{l}\text { American Society of Mechanical } \\
\text { Engineers, New York }{ }^{31}\end{array}$ \\
\hline $\begin{array}{l}\text { ANSI/ASME } \\
\text { B133.7M-1985 } \\
\text { (Reaffirmed 2001) }\end{array}$ & Gas Turbine Fuels & $\begin{array}{l}\text { American Society of Mechanical } \\
\text { Engineers, New York }{ }^{32}\end{array}$ \\
\hline $\begin{array}{l}\text { ANSI B133.8-1977 } \\
\quad \text { (Reaffirmed 2001) }\end{array}$ & Gas Turbine Installation Sound Emissions & $\begin{array}{l}\text { American Society of Mechanical } \\
\text { Engineers, New York }{ }^{33}\end{array}$ \\
\hline $\begin{array}{r}\text { ASME B133.9-1994 } \\
\text { (Reaffirmed 2001) } \\
\end{array}$ & $\begin{array}{l}\text { Measurement of Exhaust Emissions from } \\
\text { Stationary Gas Turbine Engines }\end{array}$ & $\begin{array}{l}\text { American Society of Mechanical } \\
\text { Engineers, New York }{ }^{34}\end{array}$ \\
\hline $\begin{array}{l}\text { ANSI B133.10-1981 } \\
\text { (Reaffirmed 1994) }\end{array}$ & $\begin{array}{l}\text { Procurement Standard for Gas Turbine } \\
\text { Information to be Supplied by User and } \\
\text { Manufacturer }\end{array}$ & $\begin{array}{l}\text { American Society of Mechanical } \\
\text { Engineers, New York }{ }^{35}\end{array}$ \\
\hline $\begin{array}{r}\text { ANSI B133.11-1982 } \\
\text { (Reaffirmed 1994) } \\
\end{array}$ & $\begin{array}{l}\text { Procurement Standard for Gas Turbine } \\
\text { Preparation for Shipping and Installation }\end{array}$ & $\begin{array}{l}\text { American Society of Mechanical } \\
\text { Engineers, New York }{ }^{36}\end{array}$ \\
\hline $\begin{array}{l}\text { ANSI B133.12-1981 } \\
\text { (Reaffirmed 2001) } \\
\end{array}$ & $\begin{array}{l}\text { Procurement Standard for Gas Turbine } \\
\text { Maintenance and Safety }\end{array}$ & $\begin{array}{l}\text { American Society of Mechanical } \\
\text { Engineers, New York }{ }^{37}\end{array}$ \\
\hline $\begin{array}{l}\text { API Recommended } \\
\text { Practice } 574,2 \text { nd ed. }\end{array}$ & $\begin{array}{l}\text { Inspection Practices for Piping System } \\
\text { Components }\end{array}$ & $\begin{array}{l}\text { American Petroleum Institute, } \\
\text { Washington, D.C. } 18\end{array}$ \\
\hline ISO 2314 & Gas Turbines-Acceptance Tests & $\begin{array}{l}\text { Association Francaise de } \\
\quad \text { Normalisation, Paris, France } 42\end{array}$ \\
\hline $\begin{array}{l}\text { ASTM Designation: } \\
\text { D 396-02 }\end{array}$ & Standard Specification for Fuel Oils & $\begin{array}{l}\text { American Society of Testing and } \\
\text { Materials, West } \\
\text { Conshohocken, } \\
\text { Pennsylvania } 43 \\
\end{array}$ \\
\hline
\end{tabular}


Table 3.3. (continued)

\begin{tabular}{|c|c|c|}
\hline Designation & Title & Publisher \\
\hline $\begin{array}{l}\text { ASTM Designation: } \\
\quad \text { D } 975-03\end{array}$ & Standard Specification for Diesel Fuel Oils & $\begin{array}{l}\text { American Society of Testing and } \\
\text { Materials, West } \\
\text { Conshohocken, } \\
\text { Pennsylvania }^{44}\end{array}$ \\
\hline $\begin{array}{l}\text { ASTM Designation: } \\
\text { D 2880-03 }\end{array}$ & $\begin{array}{l}\text { Standard Specification for Gas Turbine Fuel } \\
\text { Oils }\end{array}$ & $\begin{array}{l}\text { American Society of Testing and } \\
\text { Materials, West } \\
\text { Conshohocken, } \\
\text { Pennsylvania }^{45}\end{array}$ \\
\hline NFPA 54 & National Fuel Gas Code & $\begin{array}{l}\text { National Fire Protection } \\
\text { Association, Quincy, } \\
\text { Massachusetts } 46\end{array}$ \\
\hline NFPA 85 & $\begin{array}{l}\text { Boiler and Combustion Systems Hazards } \\
\text { Code }\end{array}$ & $\begin{array}{l}\text { National Fire Protection } \\
\text { Association, Quincy, } \\
\text { Massachusetts } 47\end{array}$ \\
\hline $\begin{array}{l}\text { IEEE Standard No.: 1547- } \\
\quad 2003\end{array}$ & $\begin{array}{l}\text { Standard for Interconnecting Distributed } \\
\text { Resources with Electric Power Systems }\end{array}$ & $\begin{array}{l}\text { Institute of Electrical and } \\
\text { Electronics Engineers, New } \\
\text { York }^{21}\end{array}$ \\
\hline $\begin{array}{l}\text { Federal Register, 68, No. 9, } \\
\text { 1888-1929, January 14, } \\
2003\end{array}$ & $\begin{array}{l}\text { National Emission Standards for Hazardous } \\
\text { Air Pollutants for Stationary Gas Turbines; } \\
\text { Proposed Rule }\end{array}$ & $\begin{array}{l}\text { Environmental Protection } \\
\text { Agency, Washington, D.C. }{ }^{48}\end{array}$ \\
\hline $\begin{array}{l}\text { Federal Register, 68, } \\
\text { No. } 71,17990-18002, \\
\text { April } 14,2003 \\
\end{array}$ & $\begin{array}{l}\text { Standards of Performance for Stationary Gas } \\
\text { Turbines }\end{array}$ & $\begin{array}{l}\text { Environmental Protection } \\
\text { Agency, Washington, D.C. } 49\end{array}$ \\
\hline $\begin{array}{l}\text { Federal Register, 69, No. 9, } \\
\text { 10512-10548, March 5, } \\
2004\end{array}$ & $\begin{array}{l}\text { National Emission Standards for Hazardous } \\
\text { Air Pollutants for Stationary Gas Turbines; } \\
\text { Final Rule }\end{array}$ & $\begin{array}{l}\text { Environmental Protection } \\
\text { Agency, Washington, D.C. } 50\end{array}$ \\
\hline $\begin{array}{l}\text { OAR-2003-0189; } \\
\text { RIN 2060-AK73 }\end{array}$ & $\begin{array}{l}\text { National Emission Standards for Hazardous } \\
\text { Air Pollutants for Stationary Combustion } \\
\text { Turbines-Proposed Delisting }\end{array}$ & $\begin{array}{l}\text { Environmental Protection } \\
\text { Agency, Washington, D.C. } .^{51}\end{array}$ \\
\hline $\begin{array}{l}\text { OAR-2003-0196; } \\
\text { RIN 2060-AK73 }\end{array}$ & $\begin{array}{l}\text { National Emission Standards for Hazardous } \\
\text { Air Pollutants for Stationary Combustion } \\
\text { Turbines-Stay Proposal }\end{array}$ & $\begin{array}{l}\text { Environmental Protection } \\
\text { Agency, Washington, D.C. }{ }^{52}\end{array}$ \\
\hline
\end{tabular}

$60 \%$ relative humidity at sea level. ${ }^{22}$ At inlet air temperatures near $100^{\circ} \mathrm{F}$, power output can drop to $90 \%$ or less of the specified capacity. Similarly, operating a gas turbine at elevations well above sea level results in reduced output.

Peak gas turbine efficiency occurs at $100 \%$ of the full rated load. 6 Output less than the full rated load is achieved by reducing the turbine inlet temperature, but this change in operating conditions also results in decreased gas turbine efficiency. As an example, efficiency decreases to about $75 \%$ when a gas turbine operates at only $45 \%$ of its full rated load. ${ }^{22}$

\subsubsection{Capital cost}

A basic gas turbine package consists of a gas turbine, gearbox, electrical generator, inlet and exhaust ducting, inlet air filtration, lubrication and cooling systems, standard starting system, and exhaust silencing. Options such as auxiliary equipment for starting the gas turbine during power outages can add to the cost. Depending on the size, capital costs for such packages vary between $\$ 300$ and $\$ 900 / \mathrm{kW}$ (Ref. 4); however, more precise cost data are publicly available. ${ }^{53}$ The cost of the gas turbine package 
plus the cost for added components required to implement cogeneration at a particular installation comprise the total equipment cost. These additional costs are for components such as a fuel gas compressor, heat-recovery system, water treatment system, and emission controls that may be required to make a CHP project operational. Other costs that can contribute to the total plant cost include engineering fees; installation labor and material expenses; project management costs for licensing, insurance, environmental permitting, commissioning, and startup; and interest charges. Actual installed costs can vary widely and are affected by site requirements and conditions, regional price variations, and environmental and other local permitting regulations.

Although costs may vary significantly from one site to another, there are economies of scale for larger gas turbine CHP systems. In general, the price of a gas turbine package declines only slightly between the range of 5 and $40 \mathrm{MW}$, but ancillary equipment such as the HRSG, gas compressor, water treatment, and electrical equipment are much lower in cost per unit of electrical output as the systems become larger. ${ }^{6}$

\subsubsection{Availability}

Gas turbines are capable of operating for long periods in a constant-output or base-loaded mode. When operated in this way, the service life is extended because the gas turbine is not subjected to repeated thermal and mechanical transients. The estimated availability of gas turbines operating on clean gaseous fuels like natural gas is in excess of $95 \%$.

Some gas turbines require either electrical grid power, an external hydraulic or electric motor, a small reciprocating engine, or a compressed air supply to start; others can be equipped to start with no external power sources. ${ }^{30}$ Upon starting, the electrical generator can begin delivering power within a few minutes, but the availability of steam or hot water produced by heat recovery will be delayed. The time needed to bring the heat-recovery system up to the required operating conditions varies from one installation to another.

\subsubsection{Maintenance}

Gas turbine maintenance costs are typically low, ranging from $\$ 0.002$ to $\$ 0.008 / \mathrm{kWh}$ (Ref. 4 ) for gas turbines that are fired by high-quality gaseous fuels and operate for long periods (1,000 h or more) at a time. Maintenance activities often include routine inspections, on-line and preventive maintenance, and scheduled overhauls at 12,000 to 50,000 operating-hour intervals. Routine inspections may involve visual examinations of filters and general site conditions, vibration measurements to detect worn bearings, rotors, and damaged blade tips, and other types of internal examinations of critical items such as fuel nozzles and hot gas components. Overhauls may involve dimensional inspections, product upgrades and testing of the turbine compressor, rotor removal, inspection of thrust and journal bearings, blade inspection and clearance measurements, and packing seal installation. Replacement of an entire gas turbine can sometimes be accomplished in one to four days depending on the size of the unit, but larger units often take longer.

For gas turbines that operate on a cyclic basis and for gas turbines that operate above their rated capacity for significant periods of time, maintenance costs tend to increase compared to gas turbines that operate more or less continuously at the rated load. Gas turbines fueled by liquid rather than gaseous fuels will also have increased maintenance costs and higher than average overhaul intervals. ${ }^{6}$

\subsubsection{Heat recovery}

As discussed in Sect. 3.2.3.1, overall CHP system efficiency is a function of the amount of thermal energy recovered from the gas turbine exhaust. For industrial CHP applications, heat recovery is normally 
accomplished in either a HRSG or an ICI boiler designed to produce either steam or hot water. Information about HRSGs and ICI boilers is provided in Sects. 4.1.1, 4.2.1, and Sect. 4.2.2.

A HRSG is a common heat-recovery unit used in many gas turbine CHP systems. In operation, the gas turbine exhaust flows around and through the tubes of the HRSG where thermal energy is recovered and used to produce steam or hot water. If the thermal energy in the gas turbine exhaust is not sufficient to produce the needed amount of steam or hot water, the HRSG can be equipped with a separate burner and combustion control system for supplementary fuel firing.

An ICI boiler can also be used in a gas turbine CHP system to function as a heat recovery boiler. In one application, the exhaust gas stream is directed into the combustion chamber of the boiler where it serves as preheated combustion air. This techniques is feasible because gas turbine exhaust, which is $15 \%$ or more oxygen, is capable of supporting combustion. ${ }^{22}$ As an alternative, the thermal energy in the gas turbine exhaust can be used to increase the temperature of the boiler feedwater.

Although both techniques represent effective ways to recover heat and thereby improve overall CHP system efficiency, facility modifications may be necessary at existing ICI boiler installations to implement these techniques. Using gas turbine exhaust as preheated combustion air may require modifying the facility to allow connection of the gas turbine exhaust piping to the boiler and changing the boiler control system to assure proper combustion. Changes in the emissions control and monitoring systems may also need to be considered as overall emission levels at the site will increase when the gas turbine begins operating. Other facility modifications including the addition of a heat exchanger and changing the configuration of the feedwater piping system may be necessary to recover the thermal energy in the exhaust gases and use it to heat the boiler feedwater.

To provide operating flexibility, gas turbine exhaust systems may include a diverter valve and a dump stack. The diverter valve is used to modulate the exhaust gas flow into the heat-recovery equipment or to divert the entire exhaust gas stream to the dump stack when heat recovery is not required.

\subsubsection{Fuels and emissions}

Most gas turbines are designed to fire either gaseous or liquid fuels such as natural gas or No. 2 fuel oil, but some are designed as dual-fuel units with the ability to quickly switch from one of these fuels to another. This feature may be important if fuel prices fluctuate. Because gas turbines operate at elevated pressures, gaseous fuel must be injected into the combustion chamber at a pressure that is slightly above the working pressure of the gas turbine. If the supply pressure of the gaseous fuel is insufficient, the gas turbine must be equipped with a fuel gas compressor. Pipeline quality natural gas with a heating value that ranges from about 900 to 1,100 Btu per standard cubic foot (scf) is normally a very satisfactory fuel for gas turbines, especially when it is supplied to the installation at the pipeline working pressure. When liquid fuels are used, pumps, flow controls, nozzles, and mixing systems are generally necessary to deliver the required amount of fuel to the combustion chamber at the required pressure.

Occasionally, gas turbines are designed to operate on residual or crude oil. These designs include a fuel delivery system with fuel filters, atomizers, and pretreatment equipment for eliminating potentially damaging trace elements that can result in excessive repairs or make it necessary to operate the gas turbine at lower inlet temperatures even though output and efficiency are reduced. Other contaminants such as ash, alkalis, and sulfur found in certain fuels can produce alkali sulfate deposits on gas turbine internals. Besides degrading performance, these deposits can contribute to corrosion of high-temperature components. To minimize the adverse effects of fuel contaminants on gas turbine performance, it is important for fuel specifications to include limits on these contaminants.

The primary pollutants emitted by gas turbines are $\mathrm{NO}_{\mathrm{x}}, \mathrm{CO}$, and volatile organic compounds (VOCs). Strategies commonly used to restrict $\mathrm{NO}_{\mathrm{x}}$ formation during combustion include water or steam injection to reduce the combustion temperature to levels where $\mathrm{NO}_{\mathrm{x}}$ formation is minimized and use of premix burners. These burners are designed to supply a precisely controlled mixture of fuel and air to the 
burner to minimize local zones of high temperature, thereby reducing $\mathrm{NO}_{\mathrm{x}}$ formation. The primary postcombustion $\mathrm{NO}_{\mathrm{x}}$ control technique currently in use is selective catalytic reduction (SCR). In this technique, ammonia $\left(\mathrm{NH}_{3}\right)$ is injected into the exhaust gas stream where it reacts with $\mathrm{NO}_{\mathrm{x}}$ in the presence of a catalyst to produce nitrogen $\left(\mathrm{N}_{2}\right)$ and water $\left(\mathrm{H}_{2} \mathrm{O}\right)$. The $\mathrm{CO}$ emissions are controlled using an oxidation catalyst that promotes the oxidation of $\mathrm{CO}$ and hydrocarbon compounds to $\mathrm{CO}_{2}$ and water as the exhaust gas stream flows through the catalyst bed. A relatively new emission control technique known as SCONOX ${ }^{\mathrm{TM}}$ combines catalytic conversion of $\mathrm{CO}$ and $\mathrm{NO}_{\mathrm{X}}$ with an absorption-regeneration process that eliminates the ammonia reagent found in SCR technology. In 1998, EPA Region 9 identified SCONOX ${ }^{\mathrm{TM}}$ as LAER technology for gas turbine $\mathrm{NO}_{\mathrm{x}}$ control. ${ }^{6}$ Additional information about SCR and SCONOX ${ }^{\mathrm{TM}}$ is presented in Table 4.6.

Other pollutants such as oxides of sulfur $\left(\mathrm{SO}_{\mathrm{x}}\right)$ and $\mathrm{PM}$ may also be emitted by gas turbines that fire residual or crude oil. Scrubber technology is effecting in removing both sulfur compounds and PM from exhaust gas streams, while electrostatic precipitators and bag houses are effective in reducing PM emissions. ${ }^{54,55}$

\subsubsection{Potential Applications}

Gas turbine technology has been successfully applied in both topping-cycle and combined-cycle CHP systems. Overall success is a result of low initial and maintenance costs, high availability, fuel switching capabilities, high-quality recoverable heat, and high efficiencies in larger sizes. Gas turbines also provide owners and operators with operational flexibility. They are capable of supplying electricity to satisfy either base-load or peaking power demand, and the heat recovered from gas turbine exhaust can be used to generate steam or hot water or for direct heating or drying applications. As an alternative to electricity generation, shaft power delivered by a gas turbine can be used to drive a mechanical chiller, compressor, pump, or other types of rotating machinery.

In general, gas turbines are fired by either gaseous or liquid fuels with natural gas being the preferred fuel option. Except for sites that only have access to solid fuel, adding a gas turbine package to a new or existing ICI boiler installation can be a cost-effective way to increase steam or hot water production and generate some or all of the electricity needed at the site. Economic benefits of applying gas turbine technology improve when the price of fuel is low compared to the cost of equivalent electrical energy.

Industrial sites that have access to inexpensive gaseous fuels such as landfill or synthetic gas have stable electricity demand and need a constant supply of heat for process applications, are potential candidates for topping-cycle gas turbine CHP applications. In situations where electricity and thermal demand do not coincide, a combined-cycle CHP system is an option worth considering. These systems include both gas and steam turbines and either an ICI boiler or a HRSG or both to provide heat recovery. During periods of higher electricity demand, all or a majority of the thermal output from the gas turbine can be used to produce the steam needed to power a steam turbine and electrical generator set. Under these conditions, the gas turbine operates at or near full load where efficiency is highest, and the steam turbine operates at part load with almost no loss in efficiency. As steam demand increases, all or part of the thermal output from the gas turbine can be used for process heating applications. When electrical and thermal demand occur at approximately the same time, the burner on a supplementary fired HRSG or ICI boiler can be used to produce the required amount of additional heat while the turbines are producing electricity at or near capacity.

\subsection{MICROTURBINES}

Microturbines are small gas turbines that range in size from 30 to $350 \mathrm{~kW}$. They have a relatively small number of moving parts and are capable of operating on a variety of gaseous and liquid fuels. In operation, microturbines produce high-speed rotation that drives an electrical generator. They also reject 
high-temperature exhaust gases that contain a significant amount of recoverable thermal energy. Although this technology has only been available since the late 1990s, microturbines are being used in both poweronly generation and topping-cycle and combined-cycle CHP systems.

\subsubsection{Description}

The two basic components of a microturbine are the compressor and gas turbine. An internal heat exchanger known as a recuperator is often added to recover heat from the exhaust gases and thereby improve overall energy efficiency. In operation, a radial flow (centrifugal) compressor compresses the combustion air that is then preheated in the recuperator, using heat recovered from the exhaust gas stream. After the heated air from the recuperator mixes with fuel in the combustion chamber, the hot combustion gases expand through the turbine. Microturbines are currently available in either single-shaft or two-shaft models and have sound attenuation features to reduce noise.

In single-shaft models, the compressor-turbine package is mounted on the same shaft as the electrical generator. This assembly, which is supported by either two oil-lubricated or air bearings, has high overall reliability because there is only one moving part. Single-shaft models generally operate at high speeds (over 60,000 rpm) and generate electric power with variable frequency. This power is rectified to direct current $(\mathrm{dc})$ and then inverted to $60-\mathrm{Hz}$ alternating current (ac). When a single-shaft microturbine starts, the generator acts as a motor turning the turbine-compressor shaft until sufficient speed is reached to start the combustion process. If the system is operating independent of the electrical grid, a power storage unit such as a battery is needed to power the generator during startup. Several minutes are needed to start most microturbines and achieve full-power operation. The configuration of a single-shaft microturbine with a high-speed generator is shown in Fig. 3.6.

Two-shaft models use exhaust gases from the compressor turbine to power a second turbine that drives the electrical generator. In this model, the power turbine connects to a conventional electrical generator by a gearbox. Although the two-shaft design features more moving parts, it does not require complicated power electronics to convert high frequency ac power output to $60 \mathrm{~Hz}$. The configuration of a microturbine with a conventional 3,600-rpm generator is shown in Fig. 3.7.

\subsubsection{Design and Performance Characteristics}

As a microturbine operates, atmospheric air is continuously compressed, heated, and then expanded through the turbine causing rotation. Like larger gas turbines, excess power produced by the turbine over that consumed by the compressor is used for power generation. Power produced by the expansion turbine and consumed by the compressor is proportional to the absolute temperature of the gas passing through the devices. Consequently, it is advantageous to operate the expansion turbine at the highest possible temperature and to operate the compressor with inlet airflow at as low a temperature as possible.

As technology advancements permit higher turbine inlet temperature, the optimum pressure ratio also increases. Higher temperature and pressure ratios result in higher efficiency and specific power. Thus, the general trend in gas turbine advancement has been toward a combination of higher temperatures and pressures. Based on practical considerations, current microturbine technology limits turbine inlet temperatures to about $1,800^{\circ} \mathrm{F}$ or less. This allows microturbine manufacturers to use relatively inexpensive materials for the turbine and to maintain pressure ratios at a comparatively low 3.5 to 4.0 (Ref. 7). To further improve energy efficiency, microturbine manufacturers add recuperators to reduce the amount of fuel required to produce the required inlet temperature.

Microturbine performance is highly sensitive to small variations in component performance and internal losses. This is because the high-efficiency recuperated cycle processes a much larger amount of air and combustion products flow per unit of net powered delivered than is the case for high-pressure ratio 


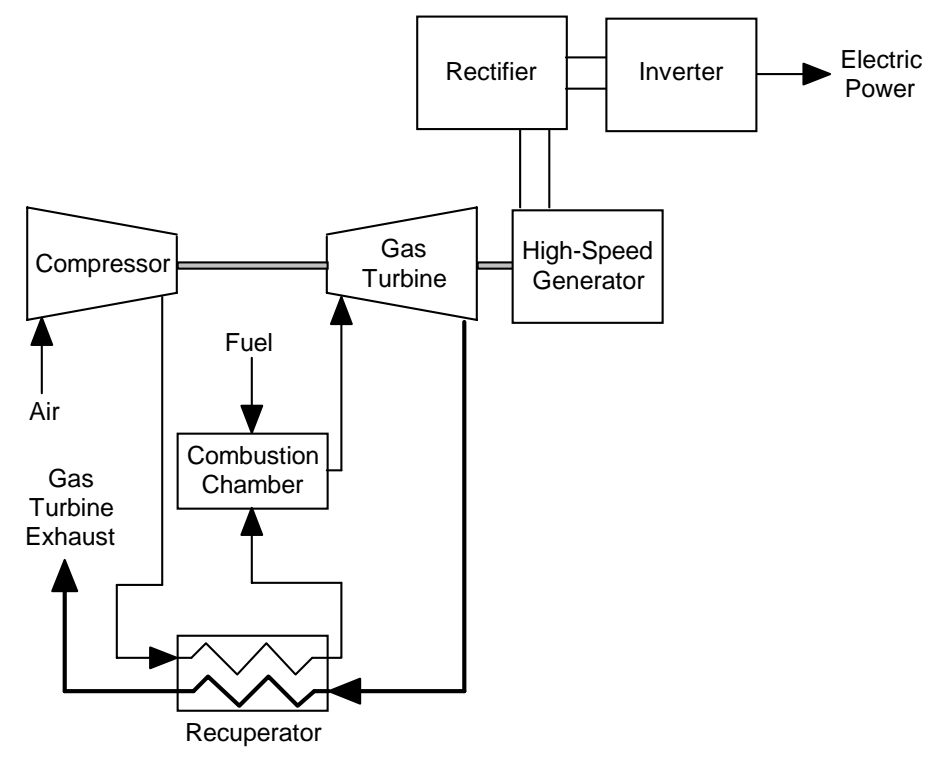

Fig. 3.6. Single-shaft microturbine with high-speed generator for CHP applications.

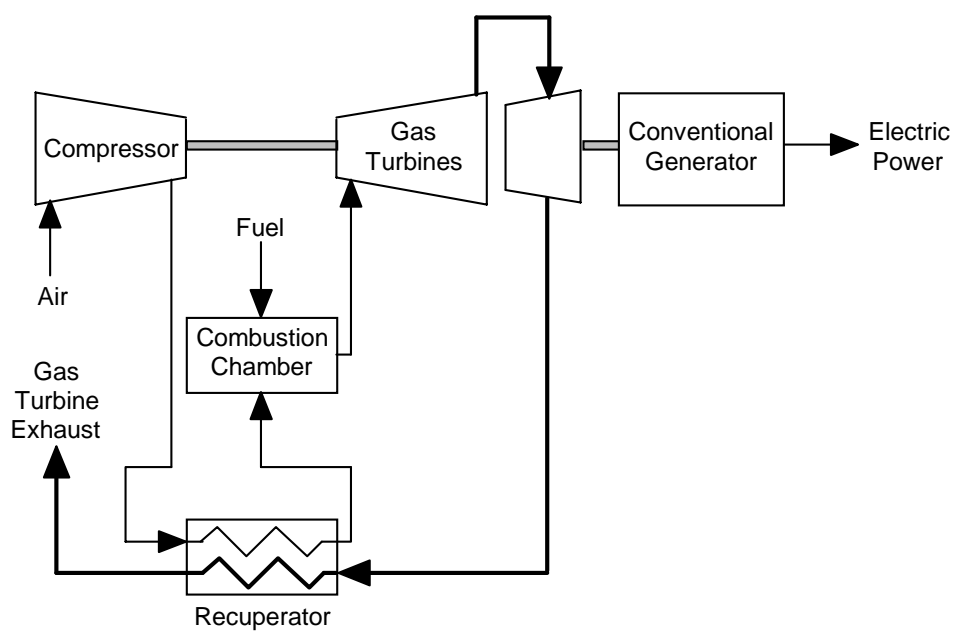

Fig. 3.7. Two-shaft microturbine with conventional generator for CHP applications.

simple-cycle gas turbines. Because the net output of a microturbine is the small difference between two large numbers (the compressor and expansion turbine work per unit of mass flow), small losses in component efficiency, internal pressure losses, and recuperator effectiveness have large impacts on net efficiency and net power per unit of mass flow. For these reasons, it is advisable to focus on trends and comparisons in considering performance, while relying on manufacturers' guarantees for precise values.

\subsubsection{Efficiency}

Current microturbine designs have maximum inlet temperatures of $1,800^{\circ} \mathrm{F}$ or less. This allows the use of relatively inexpensive materials in the high-temperature exhaust gas environment. Although 
restricting the inlet temperature is an effective way to achieve a long service life at a reasonable cost, it limits efficiency because power output is proportional to the absolute temperature of the gas that passes through the device. Because increasing the inlet temperature is not a practical option, microturbine manufacturers improve efficiency by adding a recuperator to the microturbine.

Recuperators remove heat from the exhaust gas stream and use the recovered heat to increase the temperature of the compressed air supplied to the combustion chamber. This approach reduces the amount of fuel needed to produce a specific inlet temperature and thereby increases efficiency. As an example, use of a recuperator in a microturbine with a pressure ratio of 3.2-to-1 essentially doubles the efficiency from $14 \%$ to $29 \%$. As discussed in Sect. 4.1.3, recuperators are expensive components that add to the cost of a microturbine, but the cost increase is easier to justify as the annual number of full-power operating hours increase. Microturbines with recuperators operating at full power typically achieve total CHP efficiencies ranging from $65 \%$ to $75 \%$ with E/S ratios between 0.4 and 0.7 (Ref. 7). In this context, total CHP efficiency is a function of the net electricity generated, the net heat supplied to the process, and the total fuel input expressed as follows:

(Net electricity generated + Net heat supplied to process)/Total fuel input

Operating a microturbine at less that full power involves reducing the mass flow through the turbine and decreasing the inlet temperature. These part-load operating conditions result in decreased efficiency compared to full-power operation.

The CHP electrical efficiency of a microturbine system ranges from about $18 \%$ to $29 \%$ and is based on the higher heating value (HHV) of the fuel, which includes the heat of condensation of the water vapor in the combustion products. ${ }^{7}$ Other key factors that influence CHP electrical efficiency include the pressure ratio and the inlet temperature. In general, CHP electrical efficiency increases as the inlet temperature increases and decreases as the pressure ratio declines below about 3.5-to-1 (Ref. 7). In this context, CHP electrical efficiency is a function of the net electricity generated, divided by the total fuel input.

\subsubsection{Capital cost}

The cost of a basic microturbine package that includes the turbine, generator, and power electronics ranges from about $\$ 750$ to $\$ 1,500 / \mathrm{kW}$, but when engineering, construction, auxiliary equipment, and financing costs are added to integrate the microturbine package into a CHP system, the total cost increases to about $\$ 1,300$ to $\$ 2,500 / \mathrm{kW}$ (Refs. 4 and 7). Although microturbines have limited generating capacity, it is possible to array a number of microturbine packages together to function as a multiunit power source. Installing multiple units at the same site to satisfy electricity demand or to provide redundancy can impact the capital cost of the installation.

\subsubsection{Availability}

Availability of microturbines is estimated to be $90 \%$ or better especially when multiple or backup units are installed. Multiple units operating in parallel increase generating capacity and have the potential for improving power quality and reliability. Because microturbine technology is relatively new, field service data are limited, but microturbine manufacturers have targeted availabilities about $98 \%$. The operating life of a microturbine is estimated to be in the 40,000- to $80,000-\mathrm{h}$ range. ${ }^{7}$ 


\subsubsection{Maintenance}

Estimated maintenance costs for microturbines can range up to $\$ 0.018 / \mathrm{kWh}$. This cost covers periodic inspections of the combustion chamber and bearings and regular filter replacements. Overhauls for microturbines operating on natural gas are required at 20,000- to 40,000-h intervals, but on-off cycling and use of fuels with high levels of impurities or contaminants could decrease the overhaul interval to $5,000 \mathrm{~h}$.

\subsubsection{Heat recovery}

The temperature of microturbine exhaust gases leaving the recuperator ranges from about $400^{\circ} \mathrm{F}$ to $600^{\circ} \mathrm{F}$. This heat is suitable for many process applications, including the production of hot water and lowpressure steam. Recovery of microturbine exhaust gas heat can be accomplished by directing the exhaust gas stream through either a fired or unfired HRSG. As an alternative, the exhaust gases can be mixed with combustion air supplied to an ICI boiler. This approach is feasible because the high-temperature, oxygenrich exhaust is capable of supporting combustion. Information about HRSGs and the ICI boiler is presented in Sects. 4.1.1, 4.2.1, and 4.2.2.

Heat can also be recovered by directing the exhaust gas stream through a heater exchanger where heat from the exhaust is used to increase the boiler feedwater temperature. For CHP systems that provide cooling, heat recovered from microturbine exhaust can also be used to drive an absorption chiller or a desiccant-based cooling system. Additional information about these units is discussed in Sects. 6.1 and 6.2. The amount of heat that is available for recovery depends on the use and effectiveness of a recuperator designed to remove heat from the exhaust gas stream.

\subsubsection{Fuels and emissions}

While conventional gas turbines are typically designed to burn natural gas, microturbines are capable of burning a wide variety of fuels, including natural gas and sour gases that have high-sulfur and low-Btu contents and liquid fuels, such as gasoline, kerosene, diesel fuel, and distillate fuel oil. They are also capable of burning waste gases that would otherwise be flared or released directly into the atmosphere.

Microturbines that operate on gaseous fuels use lean-premix combustion technology to reduce $\mathrm{NO}_{\mathrm{x}}$ formation. In this technique, a large amount of air is thoroughly mixed with the fuel before the fuel-air mixture is injected into the combustion zone. The high air-to-fuel ratio creates a lower flame temperature resulting in reduced $\mathrm{NO}_{\mathrm{x}}$ formation. Postcombustion techniques that can be used to reduce $\mathrm{NO}_{\mathrm{x}}$ emissions include SCR and SCONOX ${ }^{\mathrm{TM}}$. Additional information about these techniques is presented in Table 4.6.

Reducing $\mathrm{CO}$ and unburned hydrocarbon emissions requires keeping the air-fuel mixture within the combustion chamber for a relatively long period of time to promote complete fuel oxidation.

Microturbine manufacturers design the fuel firing systems to achieve a long residence time within the combustion zone.

Emission levels for microturbines that operate at full load have the potential to be extremely low. However, emission levels tend to increase under part-load operating conditions.

\subsubsection{Potential Applications}

Microturbines are ideally suited for distributed generation applications because of their flexibility in connection methods, ability to be arrayed in parallel to serve larger loads, ability to provide stable and reliable power, and low emissions. Their use in industrial topping-cycle and combined-cycle CHP applications is also possible, provided the power requirements do not exceed about $1 \mathrm{MW}$. Use of 
microturbines for larger power applications is generally not practical because the generating capacity of a single microturbine is limited to $350 \mathrm{~kW}$ or less. Achieving greater capacity requires installation of multiple microturbines arrayed in parallel. When used for smaller CHP applications, microturbines can produce electricity for base-loaded, load-tracking, or peak-shaving situations.

\subsection{RECIPROCATING INTERNAL COMBUSTION ENGINES}

Reciprocating engines are used for a variety of stationary power generation applications, including emergency power, base-load power, and peaking service. These engines are available for smaller power generation applications in sizes ranging from a few kilowatts to about $5 \mathrm{MW}$, but multiple reciprocating engines can be used to increase generating capacity and improve availability. ${ }^{1}$ Heavy-duty reciprocating engines are extremely efficient and reliable power producers with the ability to generate hot water or lowpressure steam for CHP applications.

\subsubsection{Description}

There are two basic types of reciprocating engines for power generation-spark ignition (SI) and compression ignition (CI). The SI engines use spark plugs with a high-intensity spark of timed duration to ignite a compressed air-fuel mixture within the cylinder. Gaseous or readily vaporized liquid fuels such as gasoline, propane, manufactured gas, or landfill gas are used routinely as fuel for SI engines, but natural gas is the preferred fuel for electric power generation. The CI, or diesel engines, achieve ignition through the heat of compression. They typically operate on either distillate or residual oil, but they can also be designed to operate in a dual-fuel mode, burning primarily natural gas with a small amount of diesel fuel serving as compression-ignited pilot fuel. Diesel engines have historically been the most popular type of reciprocating engines for power generation applications, but SI engines fueled by natural gas are now the engine of choice for the higher-duty-cycle stationary power market. ${ }^{8}$

Most reciprocating engines operate on a four-stroke cycle consisting of intake, compression, power, and exhaust strokes. Two revolutions of the crankshaft occur in each four-stroke cycle. Two-stroke cycle reciprocating engines operate with a compression stroke followed by a power or expansion stroke. These engines only require one revolution of the crankshaft to complete each two-stroke cycle. The air-fuel mixture needed by these engines is distributed to the various cylinders by the intake manifold and drawn into the cylinder either by natural or charged aspiration. Natural aspiration engines draw the air-fuel mixture into the cylinder at atmospheric pressure. In charged aspiration, the air-fuel mixture is supplied to the cylinder under pressure. Pressurization is accomplished either by a compressor or supercharger driven by an engine auxiliary output shaft, a separate drive, or by an exhaust-powered turbine known as a turbocharger.

Reciprocating engines are further classified as high-speed (1,000 to 3,600 rpm), medium-speed (275 to $1,000 \mathrm{rpm}$ ), or low-speed (58 to $275 \mathrm{rpm}$ ). The speed at which a power-generating reciprocating engine must operate is important because electrical generators typically run at fixed (or synchronous) speeds to maintain a constant $60-\mathrm{Hz}$ output.

\subsubsection{Design and Performance Characteristics}

Power rating, fuel consumption, and thermal output are important performance characteristics that influence the way reciprocating engines are used in CHP applications. ${ }^{23}$ Factors that affect power rating include displacement, rotational speed, method of ignition, compression ratio, type of aspiration, cooling system, jacket water temperature, and intercooler temperature. Many manufacturers rate engine capacities based on standard requirements and reference conditions. ${ }^{56}$ Knowledge about performance at reference conditions is necessary to establish engine ratings under site conditions. Fuel consumption is influenced 
by combustion cycle, rotational speed, compression ratio, and type of aspiration. For most reciprocating engines, about $30 \%$ of the fuel energy is removed by the jacket cooling system and about $30 \%$ is removed by the exhaust gases. Exhaust gas temperatures can be up to $1,200^{\circ} \mathrm{F}$ at full load and up to $1,000^{\circ} \mathrm{F}$ at $60 \%$ load for four-cycle naturally aspirated and turbocharged natural gas engines. ${ }^{23}$ Two-cycle lower speed engines have lower exhaust gas temperatures ranging from about $500^{\circ} \mathrm{F}$ to $700^{\circ} \mathrm{F}$. Some reciprocating engines have cooling systems capable of producing $200^{\circ} \mathrm{F}$ to $210^{\circ} \mathrm{F}$ hot water, while those with high pressure forced circulation and ebullient cooling systems can operate with jacket temperatures up to $265^{\circ} \mathrm{F}$. Sources of rejected thermal energy from a typical RICE for CHP applications are shown in Fig. 3.8.

Starting reciprocating engines requires minimal auxiliary power that is often supplied by batteries. Their fast-start capability allows reciprocating engines to quickly supply electricity on demand in peaking and emergency power situations.

Reciprocating engines have two operational issues that need to be considered to ensure satisfactory performance. In operation, they produce out-of-balance forces that may require special structural supports or foundations designed to absorb the dynamic forces and cyclic vibrations. Minimizing foundation requirements sometimes involves use of pneumatic support systems. Noise is also a potential problem. Although noise from reciprocating engines is somewhat less of a problem than with gas turbines, acoustic shielding may be needed to reduce noise to an acceptable level.

Codes and standards for RICE design, construction, performance, and installation are listed in Table 3.4.

\subsubsection{Efficiency}

Reciprocating engine efficiency is a function of many factors including compression ratio. High compression allows the combustion of more fuel during a single piston stroke, thus increasing engine capacity. Natural-gas-fired SI engines have compression ratios that typically range from about 9-to-1 to 12-to-1. Diesel engines operate at slightly higher compression ratios of 13-to-1. The addition of a turbocharger increases power density.

Large-capacity, low-speed, SI engines can have fuel efficiencies of about $37 \%$ for natural-gaspowered engines based on the HHV of the fuel. Discussions about the heating value of natural gas and other fuels are presented in Sect. 3.4.2.6. At reduced loads, the heat rate of SI engines increases, and efficiency decreases. The efficiency at $50 \%$ load is approximately $8 \%$ to $10 \%$ less than full-load efficiency. As the load decreases further, the curve becomes somewhat steeper. While natural-gas-fueled SI engines compare favorably to gas turbines, which typically experience efficiency decreases of

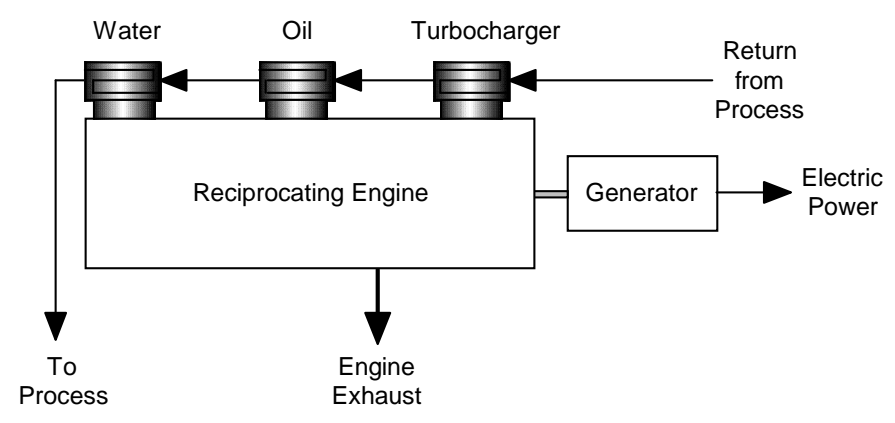

Fig. 3.8. RICE for CHP applications. 
Table 3.4. Codes and standards for RICEs

\begin{tabular}{|c|c|c|}
\hline Designation & Title & Publisher \\
\hline $\begin{array}{r}\text { ASME PTC 17-1973 } \\
\text { (Reaffirmed 2003) }\end{array}$ & $\begin{array}{l}\text { Performance Test Code on Reciprocating } \\
\text { Internal-Combustion Engines }\end{array}$ & $\begin{array}{l}\text { American Society of } \\
\text { Mechanical Engineers, New } \\
\text { York } 57\end{array}$ \\
\hline $\begin{array}{l}\text { API Recommended } \\
\text { Practice 7C-11F, 1st ed. }\end{array}$ & $\begin{array}{l}\text { Recommended Practice for Installation, } \\
\text { Maintenance, and Operation of Internal- } \\
\text { Combustion Engines }\end{array}$ & $\begin{array}{l}\text { American Petroleum Institute, } \\
\text { Washington, D.C. }{ }^{58}\end{array}$ \\
\hline ISO $8528-1,1$ st ed. & $\begin{array}{l}\text { Reciprocating Internal Combustion Engine } \\
\text { Driven Alternating Current Generating } \\
\text { Sets-Part 1: Application, Rating and } \\
\text { Performance }\end{array}$ & $\begin{array}{l}\text { International Organization for } \\
\text { Standardization, Geneva } \\
\text { Switzerland } 59\end{array}$ \\
\hline ISO $8528-2,1$ st ed. & $\begin{array}{l}\text { Reciprocating Internal Combustion Engine } \\
\text { Driven Alternating Current Generating } \\
\text { Sets-Part 2: Engines }\end{array}$ & $\begin{array}{l}\text { International Organization for } \\
\text { Standardization, Geneva } \\
\text { Switzerland } 60\end{array}$ \\
\hline ISO $8528-3,1$ st ed. & $\begin{array}{l}\text { Reciprocating Internal Combustion Engine } \\
\text { Driven Alternating Current Generating } \\
\text { Sets-Part 3: Alternating Current } \\
\text { Generators for Generating Sets }\end{array}$ & $\begin{array}{l}\text { International Organization for } \\
\text { Standardization, Geneva } \\
\text { Switzerland } 61\end{array}$ \\
\hline ISO $8528-5,1$ st ed. & $\begin{array}{l}\text { Reciprocating Internal Combustion Engine } \\
\text { Driven Alternating Current Generating } \\
\text { Sets-Part 5: Generating Sets } \\
\end{array}$ & $\begin{array}{l}\text { International Organization for } \\
\text { Standardization, Geneva } \\
\text { Switzerland } 62 \\
\end{array}$ \\
\hline ISO $3046-1,1$ st ed. & $\begin{array}{l}\text { Reciprocating Internal Combustion } \\
\text { Engines-Performance-Part 1: } \\
\text { Declarations of Power, Fuel and } \\
\text { Lubricating Oil Consumptions, and Test } \\
\text { Methods-Additional Requirements for } \\
\text { Engines for General Use }\end{array}$ & $\begin{array}{l}\text { International Organization for } \\
\text { Standardization, Geneva } \\
\text { Switzerland } 56\end{array}$ \\
\hline ISO 3046-3, 2nd ed. & $\begin{array}{l}\text { Reciprocating Internal Combustion } \\
\text { Engines-Performance-Part 3: Test } \\
\text { Measurements }\end{array}$ & $\begin{array}{l}\text { International Organization for } \\
\text { Standardization, Geneva } \\
\text { Switzerland } 63\end{array}$ \\
\hline ISO 3046-4, 2nd ed. & $\begin{array}{l}\text { Reciprocating Internal Combustion } \\
\text { Engines-Performance-Part 4: Speed } \\
\text { Governing }\end{array}$ & $\begin{array}{l}\text { International Organization for } \\
\text { Standardization, Geneva } \\
\text { Switzerland } 64\end{array}$ \\
\hline ISO 3046-5, 2nd ed. & $\begin{array}{l}\text { Reciprocating Internal Combustion } \\
\text { Engines-Performance-Part 5: Torsional } \\
\text { Vibrations, and Test Methods-Additional } \\
\text { Requirements for Engines for General Use }\end{array}$ & $\begin{array}{l}\text { International Organization for } \\
\text { Standardization, Geneva } \\
\text { Switzerland } 65\end{array}$ \\
\hline ISO 3046-6, 3rd ed. & $\begin{array}{l}\text { Reciprocating Internal Combustion } \\
\text { Engines-Performance-Part 6: } \\
\text { Overspeed Protection }\end{array}$ & $\begin{array}{l}\text { International Organization for } \\
\text { Standardization, Geneva } \\
\text { Switzerland } 66\end{array}$ \\
\hline ASME B31.1-2001 & Power Piping & $\begin{array}{l}\text { American Society of } \\
\text { Mechanical Engineers, New } \\
\text { York } 16\end{array}$ \\
\hline ASME B31.3-2002 & Process Piping & $\begin{array}{l}\text { American Society of } \\
\text { Mechanical Engineers, New } \\
\text { York } 17\end{array}$ \\
\hline ASME B31.8-2000 & $\begin{array}{l}\text { Gas Transmission and Distribution Piping } \\
\text { Systems }\end{array}$ & $\begin{array}{l}\text { American Society of } \\
\text { Mechanical Engineers, New } \\
\text { York } 41\end{array}$ \\
\hline
\end{tabular}


Table 3.4. (continued)

\begin{tabular}{|c|c|c|}
\hline Designation & Title & Publisher \\
\hline $\begin{array}{l}\text { API Recommended } \\
\text { Practice 574, 2nd ed. }\end{array}$ & $\begin{array}{l}\text { Inspection Practices for Piping System } \\
\text { Components }\end{array}$ & $\begin{array}{l}\text { American Petroleum Institute, } \\
\text { Washington, D.C. } 18\end{array}$ \\
\hline ASTM Designation: D 396-02 & Standard Specification for Fuel Oils & $\begin{array}{l}\text { American Society of Testing } \\
\text { and Materials, West } \\
\text { Conshohocken, } \\
\text { Pennsylvania } 43\end{array}$ \\
\hline ASTM Designation: D 975-03 & Standard Specification for Diesel Fuel Oils & $\begin{array}{l}\text { American Society of Testing } \\
\text { and Materials, West } \\
\text { Conshohocken, } \\
\text { Pennsylvania }^{44}\end{array}$ \\
\hline ASTM Designation: D 1835-03 & $\begin{array}{l}\text { Standard Specification for Liquefied } \\
\text { Petroleum (LP) Gases }\end{array}$ & $\begin{array}{l}\text { American Society of Testing } \\
\text { and Materials, West } \\
\text { Conshohocken, } \\
\text { Pennsylvania } 67\end{array}$ \\
\hline NFPA 54 & National Fuel Gas Code & $\begin{array}{l}\text { National Fire Protection } \\
\text { Association, Quincy, } \\
\text { Massachusetts } 46\end{array}$ \\
\hline IEEE Standard No. 1547-2003 & $\begin{array}{l}\text { Standard for Interconnecting Distributed } \\
\text { Resources with Electric Power Systems }\end{array}$ & $\begin{array}{l}\text { Institute of Electrical and } \\
\text { Electronics Engineers, New } \\
\text { York }^{21}\end{array}$ \\
\hline $\begin{array}{l}\text { Federal Register, 67, No. 244, } \\
\text { 77830-77874, December 19, } \\
2002\end{array}$ & $\begin{array}{l}\text { National Emission Standards for Hazardous } \\
\text { Air Pollutants for Stationary Reciprocating } \\
\text { Internal Combustion Engines; Proposed } \\
\text { Rule }\end{array}$ & $\begin{array}{l}\text { Environmental Protection } \\
\text { Agency, Washington, D.C. } 68\end{array}$ \\
\hline $\begin{array}{l}\text { OAR-2002-0059; } \\
\text { RIN 2060-AG-63 }\end{array}$ & $\begin{array}{l}\text { National Emission Standards for Hazardous } \\
\text { Air Pollutants for Stationary Reciprocating } \\
\text { Internal Combustion Engines }\end{array}$ & $\begin{array}{l}\text { Environmental Protection } \\
\text { Agency, Washington, D.C. } 69\end{array}$ \\
\hline
\end{tabular}

$15 \%$ to $25 \%$ at half-load conditions, multiple engines may be preferable to a single large engine to avoid efficiency penalties where significant load reductions are expected on a regular basis.

Diesel engines exhibit more favorable part-load characteristics than SI engines. The efficiency curve for diesel engines is comparatively flat between $50 \%$ and $100 \%$ load. The $\mathrm{E} / \mathrm{S}$ ratios for diesel engines are comparatively high and often range from 350 to $700 \mathrm{kWh} / \mathrm{MMBtu}$. Low-speed diesels typically are designed for peak efficiency at $75 \%$ of full load. Part-load performance for current and advanced technology high-speed diesels is excellent. Medium-speed diesels, whose rated capacities overlap high-speed diesels at the small scale and low-speed diesels at the large scale follow the same trend. ${ }^{24}$

Total CHP efficiency varies depending on size and E/S ratio. Natural-gas-fired SI engines typically have total CHP efficiencies between $70 \%$ and $80 \%$ and CHP electrical efficiencies that range from $30 \%$ to $40 \%$. In this context, total CHP efficiency is a function of the net electricity generated, the net heat supplied to the process, and the total fuel input expressed as follows:

(Net electricity generated + Net heat supplied to process)/Total fuel input

and CHP electrical efficiency is a measure of the amount of fuel energy converted into electricity. CHP electrical efficiency is a function of the net electricity generated and the total fuel input expressed as follows: 
Net electricity generated/Total fuel input

Reciprocating engine efficiency and power are reduced by approximately $4 \%$ per 1,000 feet of altitude above 1,000 feet, and about $1 \%$ for every $10^{\circ} \mathrm{F}$ above $77^{\circ} \mathrm{F}$.

\subsubsection{Capital cost}

The first cost of a reciprocating engine and generator set is generally lower than gas turbine systems in the 3- to 5-MW size range. ${ }^{8}$ Installed costs for reciprocating engine CHP systems vary from about $\$ 900$ to $\$ 1,500 / \mathrm{kW}$. Reciprocating engines have higher electrical efficiencies than gas turbines of comparable size, and thus lower fuel-related operating costs. Although maintenance costs for reciprocating engines are higher than for gas turbines, the maintenance can often be performed by inhouse staff or a local service provider.

\subsubsection{Availability}

Given proper maintenance, reciprocating engines have proven to be reliable power generators. Average annual availability is relatively high, sometimes exceeding 95\%. Expected service lifetime varies from 15 to 25 years, depending on engine size, fuel burned, and quality of maintenance. ${ }^{24}$

\subsubsection{Maintenance}

All reciprocating engines require regular maintenance and periodic repairs to provide dependable service. For diesel engines, lubricating oil and filter changes are routinely performed after 350 to $700 \mathrm{~h}$ of operation. ${ }^{23}$ Natural-gas-fueled engines can operate somewhat longer between intervals. Major overhauls for engines that operate continuously are needed about every 3 to 6 years.

\subsubsection{Heat recovery}

Thermal energy rejected by a reciprocating engine can be recovered from the exhaust, jacket cooling system, lubricating system, turbocharger, and aftercooler. When reciprocating engines are used in CHP applications, the recovered heat can be used to produce either hot water or low-pressure steam. By recovering heat in the cooling systems and exhaust, approximately $70 \%$ to $80 \%$ of the energy of the fuel is effectively utilized to produce both power and useful thermal energy.

The primary source of heat from a reciprocating engine is the engine exhaust. With temperatures that typically range from about $700^{\circ} \mathrm{F}$ to $1,000^{\circ} \mathrm{F}$, the recovered heat can be used to produce steam. ${ }^{23}$ Heat recovery is accomplished in either an unfired HRSG or a heat exchanger known as a heat-recovery muffler. Additional information about unfired HRSGs and heat-recovery mufflers is presented in Sects. 4.1.1 and 4.1.2. When the exhaust contains large amounts of excess air, the rejected heat can also be recovered in a fired HRSG or a boiler provided the pulsating nature of the exhaust gas flow does not adversely impact the combustion process.

Heat rejected by the various cooling systems can be recovered and used to produce either hot water or low-pressure steam (less than 30 psig). Ebullient cooling systems discussed in Sect. 4.1.4 recover heat by circulating a boiling coolant through the engine. Forced circulation systems, discussed in Sect. 4.1.5, recover heat by circulating a pressurized liquid coolant through the engine.

Lubricating oil, turbocharger, and aftercooler heat recovery is generally at lower temperatures. Oil temperatures are usually maintained at about $190^{\circ} \mathrm{F}$, making this heat usable for hot water generation. Turbochargers are either air- or water-cooled and have an aftercooler on the discharge side to avoid 
feeding hot, less dense air to the engine. Aftercooler water temperatures range from about $90^{\circ} \mathrm{F}$ to $135^{\circ} \mathrm{F}$ and may only be useful for specific industrial process applications.

\subsubsection{Fuels and emissions}

Reciprocating engines are fueled by propane, waste gases, diesel fuel, and fuel oil, but the preferred fuel is natural gas. Gasoline-fueled engines are generally not used for industrial CHP applications because of fuel storage hazards, fuel costs, and higher maintenance requirements compared to engines fueled by natural gas. Specifications for fuel oil, ${ }^{43}$ diesel fuel, ${ }^{44}$ and liquefied petroleum (LP) gases ${ }^{67}$ suitable for use in stationary reciprocating engines have been adopted by the American Society for Testing and Materials (ASTM).

Heating values of fuel are characterized as either HHV or lower heating value (LHV). The LHV deducts the energy necessary to keep water, which is produced during combustion, in the vapor state. Typical LHV/HHV ratios are fuel-dependent and range from 0.87 for hydrogen to 1.00 for $\mathrm{CO}$. The LHV/HHV ratio for natural gas varies from 0.9 to 0.95 depending on the mass percent hydrogen and the amount of inert gas. In general, the LHV and HHV of natural gas are approximately 900 and $1,000 \mathrm{Btu} / \mathrm{scf}$, respectively. Many manufacturers base their natural-gas engine power ratings on LHV, thereby yielding a higher reported efficiency. Heavy fuel oils have a LHV/HHV ratio equal to 0.96 , while the corresponding ratio for lighter oils is 0.93 .

All reciprocating engines emit $\mathrm{NO}_{\mathrm{x}}, \mathrm{CO}$, and unburned hydrocarbons, while engines that operate on oil also emit sulfur compounds and PM. During combustion, $\mathrm{NO}_{\mathrm{x}}$ and $\mathrm{CO}$ emissions can be reduced by using either a lean air-fuel mixture or staged ignition. Both approaches lower the combustion temperature and thereby inhibit $\mathrm{NO}_{\mathrm{x}}$ formation. A common approach for reducing $\mathrm{NO}_{\mathrm{x}}, \mathrm{CO}$, and unburned hydrocarbons emissions after combustion occurs in SI engines is to pass the exhaust gases through a catalyst or series of catalysts to remove specific pollutants. The three-way catalytic (TWC) conversion process is the basic automotive catalytic converter process that reduces concentrations of all three of these pollutants, ${ }^{8}$ but it cannot be used with $\mathrm{CI}$ engines. Reducing $\mathrm{NO}_{\mathrm{x}}$ emissions can also be accomplished using SCR, SNCR, or the more expensive SCONOX ${ }^{\mathrm{TM}}$ technique. Additional information about these techniques is presented in Table 4.6. The PM can be removed in an electrostatic precipitator or a bag house, while $\mathrm{SO}_{2}$ emissions can be reduced by passing the exhaust gases through a wet or dry scrubber. ${ }^{54,55}$ It is also possible to reduce emissions from liquid-fueled engines by using a fuel additive.

Recent developments in computer technology have improved the fuel efficiency of reciprocating engines and reduced their emissions. The SI reciprocating engines operating on natural gas have lower emission rates than diesel engines operating on liquid fuels. The final decision on fuel selection should take into consideration fuel availability, fuel cost, storage requirements, emissions requirements, and fuel consumption rate.

\subsubsection{Potential Applications}

Reciprocating engines are well suited for power generation in topping-cycle and combined-cycle $\mathrm{CHP}$ applications. Their ability to start quickly and follow load well makes reciprocating engines useful for base-load, standby, emergency, and peak shaving operation. They also exhibit good part-load efficiency and generally have high reliability. In CHP applications, hot water and low-pressure steam produced by reciprocating engines is appropriate for low-temperature process needs, space heating, and water heating. It is also suitable for driving absorption chillers that provide cold water, air conditioning, or refrigeration and for desiccant dehumidification. 


\subsection{FUEL CELLS}

Fuel cells represent an entirely different approach to the production of electricity compared to traditional prime mover technologies. Units based on fuel cell technology are similar to batteries in that both produce a dc through an electrochemical process without direct combustion of fuel. Unlike batteries that deliver power from a finite amount of stored energy, fuel cells can operate indefinitely, provided a continuous fuel source is available. As energy conversion devices, fuel cells have a number of advantages:

- high energy conversion efficiency that is relatively independent of size,

- good part-load characteristics for load-following situations,

- modular design and flexibility of size,

- low environmental impact,

- rejection of heat suitable for cogeneration, and

- quick response to load changes.

Because fuel cell technology is relatively new, current capital costs on a dollar-per-kilowatt basis are high, and there is a lack of field data on maintenance, repair, and reliability. Fuel cell operations are also sensitive to certain contaminants that may be present in the fuel such as sulfur and chlorides.

\subsubsection{Description}

All fuel cells derive energy from the oxidation of hydrogen. In operation, hydrogen and oxygen react to produce water in the presence of an electrolyte. This reaction generates an electrochemical potential that drives an electrical current through an external circuit. ${ }^{24}$ Hydrogen used as fuel can be derived from a variety of sources, including fossil fuels and renewable energy sources.

The hydrogen reformer, fuel cell stack, and inverter are the three basic components that govern the operation of a fuel cell. ${ }^{4}$ In the hydrogen reformer, hydrogen is extracted from a gaseous fuel. The fuel cell stack is an electrolyte material situated between oppositely charged electrodes where the hydrogen generates dc power in an electrochemical reaction. Conversion of dc power to ac power occurs in the inverter.

There are five types of fuel cells:

1. phosphoric acid (PAFC),

2. proton exchange membrane (PEMFC),

3. molten carbonate (MCFC),

4. solid oxide (SOFC), and

5. alkaline (AFC).

Currently, only PAFC and MCFC units are commercially available, ${ }^{5}$ and their use in CHP systems is generally restricted to low-temperature process needs such as water heating or low-pressure steam (less than 30-psig) applications. Worldwide, a number of PAFC demonstration projects are in various phases of testing or under fabrication, mostly in the 50 - to $200-\mathrm{kW}$ capacity range. The major industrial participants are from the United States and Japan. 


\subsubsection{Design and Performance Characteristics}

Today, there are only two commercially available fuel cells, a 200-kW PAFC unit and a 250-kW MCFC unit. Design and performance characteristics are provided for the more common PAFC units. Information on other types of fuel cells is available in the Fuel Cell Handbook. ${ }^{70}$

The electrolyte in a PAFC consists of concentrated phosphoric acid. A silicon carbide matrix is used to retain the acid, while both the electrodes, which also function as catalysts, are made from platinum or its alloys. The operating temperature is maintained between $300^{\circ} \mathrm{F}$ and $430^{\circ} \mathrm{F}$. At lower temperatures, phosphoric acid tends to be a poor ionic conductor, and $\mathrm{CO}$ poisoning of the platinum electrocatalyst in the anode becomes severe.

The electrochemical reactions occurring in PAFCs are

$$
\mathrm{H}_{2} \rightarrow 2 \mathrm{H}^{+}+2 \mathrm{e}^{-}
$$

at the anode, and

$$
1 / 2 \mathrm{O}_{2}+2 \mathrm{H}^{+}+2 \mathrm{e}^{-} \rightarrow \mathrm{H}_{2} \mathrm{O}
$$

at the cathode. The overall reaction is

$$
1 / 2 \mathrm{O}_{2}+\mathrm{H}_{2} \rightarrow \mathrm{H}_{2} \mathrm{O}
$$

Note that the fuel cell operates on $\mathrm{H}_{2}$, while $\mathrm{CO}$ is a poison when present in a concentration greater than $0.5 \%$. If a hydrocarbon such as natural gas is used as a fuel, reforming of the fuel by the reaction

$$
\mathrm{CH}_{4}+\mathrm{H}_{2} \mathrm{O} \rightarrow 3 \mathrm{H}_{2}+\mathrm{CO}
$$

and shift of the reformate by the reaction

$$
\mathrm{CO}+\mathrm{H}_{2} \mathrm{O} \rightarrow \mathrm{H}_{2}+\mathrm{CO}_{2}
$$

are required to generate the required hydrogen fuel. Any sulfur compounds present in the fuel have to be removed prior to use in the cell (upstream of the reformer) to a concentration of $<0.1$ parts per million by volume (ppmV). The fuel cell itself, however, can tolerate a maximum of $50 \mathrm{ppmV}$ of sulfur compounds. There is also a limit on the CO concentration in the fuel gas of $0.5 \%$. The operating temperature of a PAFC is about $390^{\circ} \mathrm{F}$ with phosphoric acid concentrations of $100 \%$.

In general, fuel cells produce low noise levels (60 dBA at $30 \mathrm{ft}$ ) and do not vibrate. Consequently, it may be possible to site a fuel cell inside a building, but fan noise and moisture venting need to be considered in the site selection process. Codes and standards for fuel cell performance and installation are listed in Table 3.5. The general arrangement of PAFC components is shown in Fig. 3.9.

\subsubsection{Efficiency}

One of the main advantages of fuel cells is the high conversion efficiency that may range from $36 \%$ to $54 \%$ based on the HHV of the fuel. The fuel conversion efficiency is higher than that of most energy conversion systems, and the efficiency advantage becomes more significant at the smaller scales because the efficiency of fuel cells is nearly constant with size. For a PAFC, the conversion efficiency of fuel bound energy to electricity is typically 36 to $42 \%$ on a fuel (natural gas) HHV basis. When waste heat is effectively recovered and used for process applications, total CHP efficiency can be as high as $85 \%$. In 
Table 3.5. Codes and standards for fuel cells

\begin{tabular}{|l|l|l|}
\hline \multicolumn{1}{|c|}{ Designation } & \multicolumn{1}{|c|}{ Title } & \multicolumn{1}{c|}{ Publisher } \\
\hline ASME PTC 50-2002 & $\begin{array}{l}\text { Performance Test Code on Fuel Cell Power } \\
\text { Systems Performance }\end{array}$ & $\begin{array}{l}\text { American Society of } \\
\text { Mechanical Engineers, New } \\
\text { York }\end{array}$ \\
\hline ASME B31.8-2000 & $\begin{array}{l}\text { Gas Transmission and Distribution Piping } \\
\text { Systems }\end{array}$ & $\begin{array}{l}\text { American Society of } \\
\text { Mechanical Engineers, New } \\
\text { York } 41\end{array}$ \\
\hline $\begin{array}{l}\text { API Recommended } \\
\text { Practice 574, 2nd ed. }\end{array}$ & $\begin{array}{l}\text { Inspection Practices for Piping System } \\
\text { Components }\end{array}$ & $\begin{array}{l}\text { American Petroleum Institute, } \\
\text { Washington, D.C. } 18\end{array}$ \\
\hline NFPA 853 & $\begin{array}{l}\text { Standards for the Installation of Stationary } \\
\text { Fuel Cell Power Plants }\end{array}$ & $\begin{array}{l}\text { National Fire Protection } \\
\text { Association, Quincy, } \\
\text { Massachusetts }\end{array}$ \\
\hline IEEE Standard No. 1547-2003 & Standard for Interconnecting Distributed \\
Resources with Electric Power Systems & $\begin{array}{l}\text { Institute of Electrical and } \\
\text { Electronics Engineers, New } \\
\text { York } 21\end{array}$ \\
\hline
\end{tabular}

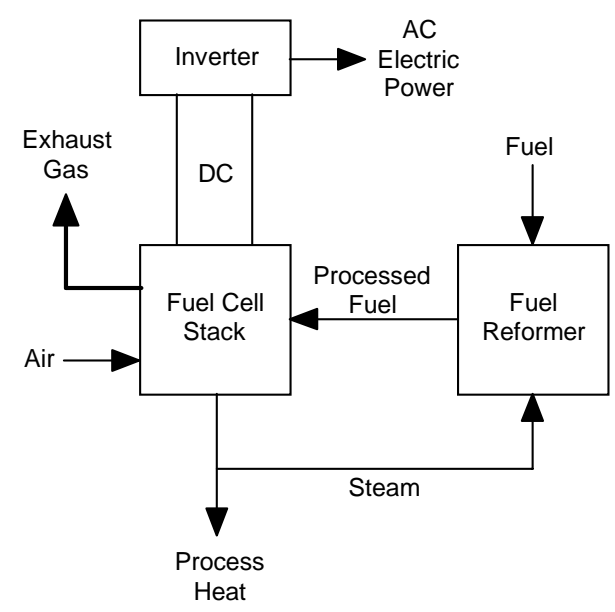

Fig. 3.9. PAFC for CHP applications.

this context, total CHP efficiency is a function of the net electricity generated, the net heat supplied to the process, and the total fuel input expressed as follows:

(Net electricity generated + Net heat supplied to process)/Total fuel input

The efficiency under $50 \%$ load is within $2 \%$ of its full-load efficiency, but as the load decreases, the curve becomes somewhat steeper. ${ }^{5}$ This performance characteristic means that fuel cells have excellent load following capability with steady efficiency down to about one-third of rated capacity. 


\subsubsection{Capital cost}

The installed cost of a fuel cell system designed for use in a CHP application is high, ranging from about $\$ 2,800$ to $\$ 5,500 / \mathrm{kW}$. This includes the fuel cell plus auxiliary equipment costs. In a typical installation, the stack subsystem represents from $25 \%$ to $40 \%$ of the cost, the fuel processing subsystem from $25 \%$ to $30 \%$, the power and electronics subsystem from $10 \%$ to $20 \%$, the thermal management subsystem from $10 \%$ to $20 \%$, and ancillary subsystems from $5 \%$ to $15 \%$. Major barriers to the widespread use of fuel cells is their high initial installed $\operatorname{cost}^{5}$ and their limited service history. Based on current fuel and electricity prices, fuel cell system costs will need to decrease to about $\$ 1,000 / \mathrm{kW}$ before fuel cell technology becomes competitive with other types of prime movers for most CHP applications. ${ }^{4}$

\subsubsection{Availability}

Fuel cells have demonstrated greater than $90 \%$ availability based on limited long-term operating experience, and some PAFC units have achieved operational lives of 70,000 h (less than 10 years).$^{5}$

\subsubsection{Maintenance}

Routine fuel cell maintenance involves inspections and adjustments and periodic filter replacements. Major overhauls include catalyst replacement about every 3 to 5 years, reformer catalysts replacement about every 5 years, and stack replacement about every 4 to 8 years. Maintenance costs range from about $\$ 0.007$ to $0.02 / \mathrm{kWh}$ excluding stack replacement. ${ }^{5}$

\subsubsection{Heat recovery}

There are four potential sources of useable heat from a fuel cell: exhaust gas including water condensation, stack cooling, anode off-gas combustion, and reformer heat. ${ }^{5}$ About $25 \%$ to $45 \%$ of the available heat can be recovered from the stack cooling loop that operates at about $400^{\circ} \mathrm{F}$. The exhaust gas cooling loop provides the balance of the heat. Maximum system efficiency occurs when all of the available anode off-gas heat and internal reformer heat is used internally.

Heat generated during operation is removed by either liquid or gaseous coolants that are routed through cooling channels in the stack. Complex manifolds and connections are required for liquid cooling, but better heat transfer is achieved than with air cooling. Gas cooling on the other hand has simplicity, reliability, and relatively low cost. For PAFCs, the recovered heat can be used effectively to increase the temperature of boiler feedwater.

\subsubsection{Fuels and emissions}

Hydrogen used by a fuel cell can be derived from a variety of sources such as natural gas, liquefied petroleum gases, including propane-butane mixtures, coal, biomass, or, potentially through electrolysis, wind, and solar energy. Fuel contaminants such as sulfur and chlorides must be reduced to acceptable levels prior to entering the fuel processing catalyst because they are detrimental to catalyst life.

Fuel cells produce virtually no regulated air pollutants because the primary power generating process does not involve combustion. Some emissions are released, however, when surface burner elements are used to provide heat for the reforming process. If the temperature of the combustion process is maintained at less than $1,800^{\circ} \mathrm{F}$, the formation of thermal $\mathrm{NO}_{\mathrm{x}}$ is minimized, and the temperature is sufficiently high to control $\mathrm{CO}$ and VOC emissions. 


\subsubsection{Potential Applications}

Fuel cells are most effective in installations with relatively high and coincident electricity and heating needs. Although fuel cells are currently only available with limited generating capacity, multiple fuel cells can be installed to increase electrical output to a megawatt or more. Use of multiple fuel cells can be beneficial because they can be synchronized to meet changing demands.

In CHP topping-cycle and combined-cycle applications, waste heat rejected by a fuel cell can be used to preheat boiler feedwater, produce hot water, or generate low-pressure steam. The time needed to start up a fuel cell is relatively long. Because of this characteristic, fuel cells are effective for base-loaded service, but are not well suited for peak shaving or standby service.

\subsection{REFERENCES}

1. N. Petchers, Combined Heating, Cooling and Power Handbook: Technologies and Applications, The Fairmont Press, Inc., Lilburn, Georgia, 2003.

2. Technology Characterization: Steam Turbines, prepared by Energy Nexus Group for the U.S. Environmental Protection Agency, Washington, D.C., March 2002.

3. H. P. Bloch, A Practical Guide to Steam Turbine Technology, The McGraw-Hill Companies, Inc., New York, 1996.

4. Combined Heat and Power: A Federal Manager's Resource Guide, prepared by Aspen Systems Corp. for the U.S. Department of Energy, Washington, D.C., March 2000.

5. Technology Characterization: Fuel Cells, prepared by Energy Nexus Group for the U.S.

Environmental Protection Agency, Washington, D.C., April 2002.

6. Technology Characterization: Gas Turbines, prepared by Energy Nexus Group for the U.S. Environmental Protection Agency, Washington, D.C., February 2002.

7. Technology Characterization: Microturbines, prepared by Energy Nexus Group for the U.S. Environmental Protection Agency, Washington, D.C., March 2002.

8. Technology Characterization: Reciprocating Engines, prepared by Energy Nexus Group for the U.S. Environmental Protection Agency, Washington, D.C., February 2002.

9. "Water Permitting 101," Office of Waste Management—Water Permitting, U.S. Environmental Protection Agency. http://www.epa.gov/npdes/pubs/101pape.pdf

10. Petroleum, Petrochemical, and Natural Gas Industries-Steam Turbines-Special-purpose Applications, API Standard 612, 5th ed., American Petroleum Institute, Washington, D.C., July 2003.

11. Performance Test Code on Steam Turbines, ASME PTC 6-1996, American Society of Mechanical Engineers, New York, 1996.

12. Procedures for Routine Performance Tests of Steam Turbines, ASME PTC 6S Report-1988

(Reaffirmed 1995), American Society of Mechanical Engineers, New York, 1988.

13. Guidance for Evaluation of Measurement Uncertainty in Performance Tests of Steam Turbines, ASME PTC 6 Report-1985 (Reaffirmed 1997), American Society of Mechanical Engineers, New York, 1985.

14. Test Code for Steam Turbines, Appendix A to PTC 6, ASME PTC 6A-2001, American Society of Mechanical Engineers, New York, 2001.

15. Recommended Practices for the Prevention of Water Damage to Steam Turbines Used for Electric Power Generation, ASME TDP 1-1998, American Society of Mechanical Engineers, New York, 1998.

16. Power Piping, ASME B31.1-2001, American Society of Mechanical Engineers, New York, 2001.

17. Process Piping, ASME B31.3-2002, American Society of Mechanical Engineers, New York, 2002. 
18. Inspection Practices for Piping System Components, API Recommended Practice 574, 2nd ed., American Petroleum Institute, Washington, D.C., June 1998.

19. “Steam Turbines for Mechanical Drive Service," NEMA Standards Publication No. SM 23-1991 (R1997, R2002), National Electrical Manufacturers Association, Rosslyn, Virginia, 1991.

20. "Land-Based Steam Turbine Generator Sets 0-33,000 kW," NEMA Standards Publication No. SM 24-1991 (R1997, R2002), National Electrical Manufacturers Association, Rosslyn, Virginia, 1991.

21. Standard for Interconnecting Distributed Resources with Electric Power Systems, IEEE Standard No. 1547-2003, Institute of Electrical and Electronics Engineers, New York, 2003.

22. J. A. Orlando, Cogeneration Design Guide, American Society of Heating, Refrigerating and AirConditioning Engineers, Inc., Atlanta, Georgia, 1996.

23. "Cogeneration Systems and Engine and Turbine Drives," Chapter 7, ASHRAE HandbookHVAC Systems and Equipment, American Society of Heating, Refrigerating and Air-Conditioning Engineers, Inc., Atlanta, Georgia, July 6, 2000.

24. Industrial and Commercial Cogeneration, Office of Technology Assessment, Congressional Board of the 98th Congress, Washington, D.C., February 1983.

25. C. B. Oland, Guide to Low-Emission Boiler and Combustion Equipment Selection, ORNL/TM-2002/19, Oak Ridge National Laboratory, Oak Ridge, Tennessee, April 2002.

26. R. Peltier, "Repowering Breathes New Life into Old Plants," Power, 147(5) (June 2003).

27. Gas Turbines: Procurement, Part 1: General Introduction and Definitions, ASME 3977 1-2000, American Society of Mechanical Engineers, New York, 2000.

28. Gas Turbines: Procurement, Part 2: Standard Reference Conditions and Ratings, ASME

3977 2-2000, American Society of Mechanical Engineers, New York, 2000.

29. Procurement Standard for Gas Turbine Auxiliary Equipment, ANSI B133.3-1981 (Reaffirmed 1994), American Society of Mechanical Engineers, New York, 1981.

30. Gas Turbine Control and Protection Systems, ANSI B133.4-1978 (Reaffirmed 1997), American Society of Mechanical Engineers, New York, 1978.

31. Procurement Standard for Gas Turbine Electrical Equipment, ANSI B133.5-1978 (Reaffirmed 1997), American Society of Mechanical Engineers, New York, 1978.

32. Gas Turbine Fuels, ANSI/ASME B133.7M-1985 (Reaffirmed 2001), American Society of Mechanical Engineers, New York, 1985.

33. Gas Turbine Installation Sound Emissions, ANSI B133.8-1977 (Reaffirmed 2001), American Society of Mechanical Engineers, New York, 1977.

34. Measurement of Exhaust Emissions from Stationary Gas Turbine Engines, ASME B133.9-1994

(Reaffirmed 2001), American Society of Mechanical Engineers, New York, 1994.

35. Procurement Standard for Gas Turbine Information to be Supplied by User and Manufacturer, ANSI B133.10-1981 (Reaffirmed 1994), American Society of Mechanical Engineers, New York, 1981.

36. Procurement Standard for Gas Turbine Preparation for Shipping and Installation, ANSI

B133.11-1982 (Reaffirmed 1994), American Society of Mechanical Engineers, New York, 1982.

37. Procurement Standard for Gas Turbine Maintenance and Safety, ANSI B133.12-1981

(Reaffirmed 2001), American Society of Mechanical Engineers, New York, 1981.

38. Gas Turbines for the Petroleum, Chemical, and Gas Industry Services, API Standard 616, 4th ed., American Petroleum Institute, Washington, D.C., August 1998.

39. Recommended Practice for Packaged Combustion Gas Turbines, API Recommended

Practice 11PGT, 1st ed., American Petroleum Institute, Washington, D.C., May 1, 1992.

40. Performance Test Code on Gas Turbines, ASME PTC 22-1997, American Society of

Mechanical Engineers, New York, 1997.

41. Gas Transmission and Distribution Piping Systems, ASME B31.8-2000, American Society of Mechanical Engineers, New York, 2000. 
42. Gas Turbines-Acceptance Tests, ISO 2314, International Organization for Standardization, Geneva Switzerland, 1999.

43. "Standard Specification for Fuel Oils," ASTM Designation: D 396-02, American Society of Testing and Materials, West Conshohocken, Pennsylvania, 2002.

44. "Standard Specification for Diesel Fuel Oils," ASTM Designation: D 975-03, American Society of Testing and Materials, West Conshohocken, Pennsylvania, 2003.

45. "Standard Specification for Gas Turbine Fuel Oils," ASTM Designation: D 2880-03, American Society of Testing and Materials, West Conshohocken, Pennsylvania, 2003.

46. "National Fuel Gas Code, NFPA 54, National Fire Protection Association, Quincy, Massachusetts, July 19, 2002.

47. "Boiler and Combustion Systems Hazards Code," NFPA 85, National Fire Protection Association, Quincy, Massachusetts, February 9, 2001.

48. "National Emission Standards for Hazardous Air Pollutants for Stationary Gas Turbines;

Proposed Rule," Federal Register, 68, No. 9, 1888-1929, January 14, 2003.

49. "Standards of Performance for Stationary Gas Turbines," Federal Register, 68, No. 71, 1799018002, April 14, 2003.

50. "National Emission Standards for Hazardous Air Pollutants for Stationary Gas Turbines; Final Rule," Federal Register, 69, No. 9, 10512-10548, March 5, 2004.

51. National Emission Standards for Hazardous Air Pollutants for Stationary Combustion Turbines-Proposed Delisting, OAR-2003-0189; RIN 2060-AK73, U.S. Environmental Protection Agency, Washington, D.C.

52. National Emission Standards for Hazardous Air Pollutants for Stationary Combustion Turbines-Stay Proposal, OAR-2003-0196; RIN 2060-AK73, U.S. Environmental Protection Agency, Washington, D.C.

53. Gas Turbine World Handbook, Pequot Publishing, Inc., Fairfield, Connecticut, 2003.

54. Combustion Fossil Power, 4th ed., ed. J. G. Singer, Combustion Engineering, Inc., Windsor, Connecticut, 1991.

55. Steam, Its Generation and Use, 40th ed., eds. S. C. Stultz and J. B. Kitto, Babcock and Wilcox, Barberton, Ohio, 1992.

56. Reciprocating Internal Combustion Engines-Performance-Part 1: Declarations of Power, Fuel and Lubricating Oil Consumptions, and Test Methods-Additional Requirements for Engines for General Use, ISO 3046-1, 5th ed., International Organization for Standardization, Geneva, Switzerland, May 1, 2002.

57. Performance Test Code on Reciprocating Internal-Combustion Engines, ASME PTC 17-1973 (Reaffirmed 2003), American Society of Mechanical Engineers, New York, 1973.

58. Recommended Practice for Installation, Maintenance, and Operation of Internal-Combustion Engines, API Recommended Practice 7C-11F, 1st ed., American Petroleum Institute, Washington, D.C., November 1, 1994.

59. "Reciprocating Internal Combustion Engine Driven Alternating Current Generating SetsPart 1: Application, Rating and Performance," ISO 8528-1, 1st ed., International Organization for Standardization, Geneva, Switzerland, January 1, 1993.

60. "Reciprocating Internal Combustion Engine Driven Alternating Current Generating SetsPart 2: Engines," ISO 8528-2, 1st ed., International Organization for Standardization, Geneva Switzerland, January 1, 1993.

61. "Reciprocating Internal Combustion Engine Driven Alternating Current Generating SetsPart 3: Alternating Current Generators for Generating Sets," ISO 8528-3, 1st ed., International Organization for Standardization, Geneva, Switzerland, January 1, 1993. 
62. "Reciprocating Internal Combustion Engine Driven Alternating Current Generating SetsPart 5: Generating Sets," ISO 8528-5, 1st ed., International Organization for Standardization, Geneva, Switzerland, January 1, 1993.

63. Reciprocating Internal Combustion Engines-Performance-Part 3: Test Measurements, ISO 3046-3, 2nd ed., International Organization for Standardization, Geneva Switzerland, January 1, 1989.

64. Reciprocating Internal Combustion Engines - Performance - Part 4: Speed Governing, ISO 3046-4, 2nd ed., International Organization for Standardization, Geneva, Switzerland, March 15, 1987.

65. Reciprocating Internal Combustion Engines-Performance-Part 5: Torsional Vibrations, and Test Methods-Additional Requirements for Engines for General Use, ISO 3046-5, 2nd ed., International Organization for Standardization, Geneva Switzerland, December 1, 2001.

66. Reciprocating Internal Combustion Engines-Performance-Part 6: Overspeed Protection, ISO 3046-6, 3rd ed., International Organization for Standardization, Geneva, Switzerland, October 1, 1990.

67. "Standard Specification for Liquefied Petroleum (LP) Gases," ASTM Designation: D 1835-03, American Society of Testing and Materials, West Conshohocken, Pennsylvania, 2003.

68. "National Emission Standards for Hazardous Air Pollutants for Stationary Reciprocating Internal Combustion Engines; Proposed Rule," Federal Register, 67, No. 244, 77830-77874, December 19, 2002.

69. National Emission Standards for Hazardous Air Pollutants for Stationary Reciprocating Internal Combustion Engines, OAR-2002-0059; RIN 2060-AG-63, U.S. Environmental Protection Agency, Washington, D.C.

70. J. H. Hirschenhofer, D. B. Stauffer, R. R. Engleman, and M. G. Klett, Fuel Cell Handbook, 4th ed., DOE/FETC-99/1076, U.S. Department of Energy, Office of Fossil Energy, Morgantown, West Virginia, November 1998.

71. Performance Test Code on Fuel Cell Power Systems Performance, ASME PTC 50-2002, American Society of Mechanical Engineers, New York, 2002.

72. "Standards for the Installation of Stationary Fuel Cell Power Plants," NFPA 853, National Fire Protection Association, Quincy, Massachusetts, August 18, 2000. 


\section{HEAT-RECOVERY EQUIPMENT}

Heat-recovery equipment is used in CHP systems to capture thermal energy rejected from prime movers and other heating sources and to make the recovered heat available for useful purposes. By extracting thermal energy from exhaust gas streams and liquid coolant circuits, heat-recovery units reduce fuel consumption and thereby increase overall energy efficiency.

Simple heat-recovery units function as heat exchangers by transferring thermal energy from one system to another. These units are characterized as unfired heat-recovery units because they receive thermal energy from an independent heating source and have no ability to generate additional heat. More complex units are characterized as supplementary fired heat-recovery units because they include both heat transfer surfaces and fuel-firing equipment. These units are designed to supplement the heat provided by the primary heating source with thermal energy generated by combustion of additional fuel. Depending on the design of the installation and the process heating and power requirements, it may be necessary to use both fired and unfired heat-recovery units in the same CHP system. Codes and standards for the design, construction, installation, inspection, performance, and testing of various types of heat-recovery equipment are listed in Table 4.1.

\subsection{UNFIRED UNITS}

Unfired heat-recovery units are used in CHP applications to extract heat rejected from reciprocating engines, gas turbines, microturbines, and fuel cells. The waste heat is contained in exhaust gas streams and liquid coolant circuits. Names that describe unfired heat-recovery units commonly used in CHP systems include

- unfired HRSG,

- heat-recovery muffler,

- regenerator,

- recuperator,

- ebullient cooling system,

- forced circulation system,

- aftercooler, and

- heat exchanger.

The simplest unfired heat-recovery units used in CHP applications are liquid-to-liquid heat exchangers that use rejected heat from reciprocating engine jacket coolant or fuel cells to increase the temperature of boiler feedwater. ${ }^{1}$ Larger and more complex HRSGs and heat-recovery mufflers are used to recover heat from gas turbine and reciprocating engine exhaust to produce steam. Because unfired heatrecovery units do not burn fuel to produce heat, they are not a source of regulated air pollutants.

As discussed in Sect. 3.4, approximately $30 \%$ of the energy input to a reciprocating engine is removed by the jacket coolant circuit. ${ }^{2}$ Depending on the design of the jacket coolant system, thermal energy available from this source can be recovered as either hot water or low-pressure steam. An additional $10 \%$ of the energy input to a reciprocating engine is rejected into the lubricating oil system. Much of this heat can be recovered as hot water. Heat in the form of hot water can also be recovered from reciprocating engines equipped with turbochargers. A turbocharger is an air compressor that is powered by hot, high-velocity exhaust gases leaving the engine. Heat exchangers designed to cool the discharge air from turbochargers are commonly known as aftercoolers or intercoolers. Thermal energy recovered from 
Table 4.1. Codes and standards for heat-recovery equipment

\begin{tabular}{|c|c|c|}
\hline Designation & Title & Publisher \\
\hline API Publication 534, 1st ed. & Heat Recovery Steam Generators & $\begin{array}{l}\text { American Petroleum Institute, } \\
\text { Washington, D.C. }{ }^{3}\end{array}$ \\
\hline $\begin{array}{l}\text { API Recommended } \\
\text { Practice 556, 1st ed. }\end{array}$ & $\begin{array}{l}\text { Instrumentation and Control Systems for } \\
\text { Fired Heaters and Steam Generators }\end{array}$ & $\begin{array}{l}\text { American Petroleum Institute, } \\
\text { Washington, D.C. }{ }^{4}\end{array}$ \\
\hline $\begin{array}{l}\text { API Recommended } \\
\text { Practice 572, 2nd ed. }\end{array}$ & $\begin{array}{l}\text { Inspection of Pressure Vessels (Towers, } \\
\text { Drums, Reactors, Heat Exchangers, and } \\
\text { Condensers) }\end{array}$ & $\begin{array}{l}\text { American Petroleum Institute, } \\
\text { Washington, D.C. }{ }^{5}\end{array}$ \\
\hline $\begin{array}{l}\text { API Recommended } \\
\text { Practice 573, 2nd ed. }\end{array}$ & Inspection of Fired Boilers and Heaters & $\begin{array}{l}\text { American Petroleum Institute, } \\
\text { Washington, D.C. }{ }^{6}\end{array}$ \\
\hline ASME PTC 4-1998 & $\begin{array}{l}\text { Performance Test Code on Fired Steam } \\
\text { Generators }\end{array}$ & $\begin{array}{l}\text { American Society of Mechanical } \\
\text { Engineers, New York }{ }^{7}\end{array}$ \\
\hline $\begin{array}{l}\text { ASME PTC } 4.3 \text { (Reaffirmed } \\
\text { 1991) }\end{array}$ & Performance Test Code on Air Heaters & $\begin{array}{l}\text { American Society of Mechanical } \\
\text { Engineers, New York }\end{array}$ \\
\hline $\begin{array}{l}\text { ASME PTC 4.4-1981 } \\
\text { (Reaffirmed 2003) }\end{array}$ & $\begin{array}{l}\text { Performance Test Code on Gas Turbine Heat } \\
\text { Recovery Steam Generators }\end{array}$ & $\begin{array}{l}\text { American Society of Mechanical } \\
\text { Engineers, New York } 9\end{array}$ \\
\hline ASME PTC 12.2-1998 & $\begin{array}{l}\text { Performance Test Code on Steam Surface } \\
\text { Condensers }\end{array}$ & $\begin{array}{l}\text { American Society of Mechanical } \\
\text { Engineers, New York }{ }^{10}\end{array}$ \\
\hline $\begin{array}{l}\text { ASME PTC 23-1986, } \\
\text { (Reaffirmed 1997) }\end{array}$ & $\begin{array}{l}\text { Performance Test Code on Atmospheric } \\
\text { Water Cooling Equipment }\end{array}$ & $\begin{array}{l}\text { American Society of Mechanical } \\
\text { Engineers, New York }{ }^{11}\end{array}$ \\
\hline $\begin{array}{l}\text { Section I, } 2001 \text { ASME Boiler } \\
\text { and Pressure Vessel Code }\end{array}$ & Power Boilers & $\begin{array}{l}\text { American Society of Mechanical } \\
\text { Engineers, New York }{ }^{12}\end{array}$ \\
\hline $\begin{array}{l}\text { Section IV, } 2001 \text { ASME Boiler } \\
\text { and Pressure Vessel Code }\end{array}$ & Heating Boilers & $\begin{array}{l}\text { American Society of Mechanical } \\
\text { Engineers, New York }{ }^{13}\end{array}$ \\
\hline $\begin{array}{l}\text { Section VI, } 2001 \text { ASME Boiler } \\
\text { and Pressure Vessel Code }\end{array}$ & $\begin{array}{l}\text { Recommended Rules for the Care and } \\
\text { Operation of Heating Boilers }\end{array}$ & $\begin{array}{l}\text { American Society of Mechanical } \\
\text { Engineers, New York }{ }^{14}\end{array}$ \\
\hline $\begin{array}{l}\text { Section VII, } 2001 \text { ASME Boiler } \\
\text { and Pressure Vessel Code }\end{array}$ & $\begin{array}{l}\text { Recommended Guidelines for the Care of } \\
\text { Power Boilers }\end{array}$ & $\begin{array}{l}\text { American Society of Mechanical } \\
\text { Engineers, New York }\end{array}$ \\
\hline ASME B31.1-2001 & Power Piping & $\begin{array}{l}\text { American Society of Mechanical } \\
\text { Engineers, New York }{ }^{16}\end{array}$ \\
\hline ASME B31.3-2002 & Process Piping & $\begin{array}{l}\text { American Society of Mechanical } \\
\text { Engineers, New York }{ }^{17}\end{array}$ \\
\hline ASME B31.8-2000 & $\begin{array}{l}\text { Gas Transmission and Distribution Piping } \\
\text { Systems }\end{array}$ & $\begin{array}{l}\text { American Society of Mechanical } \\
\text { Engineers, New York }{ }^{18}\end{array}$ \\
\hline ASTM Designation: D 388-99 & Standard Classification of Coals by Rank & $\begin{array}{l}\text { American Society of Testing and } \\
\text { Materials, West } \\
\text { Conshohocken, } \\
\text { Pennsylvania }{ }^{19}\end{array}$ \\
\hline ASTM Designation: D 396-02 & Standard Specification for Fuel Oils & $\begin{array}{l}\text { American Society of Testing and } \\
\text { Materials, West } \\
\text { Conshohocken, } \\
\text { Pennsylvania }{ }^{20}\end{array}$ \\
\hline
\end{tabular}


Table 4.1. (continued)

\begin{tabular}{lcc}
\hline \multicolumn{1}{c}{ Designation } & Title & \multicolumn{1}{c}{ Publisher } \\
\hline NFPA 54 & National Fuel Gas Code & National Fire Protection \\
& & Association, Quincy, \\
& & Massachusetts \\
& & \\
NFPA 85 & Boiler and Combustion Systems Hazards & National Fire Protection \\
& Code & Association, Quincy, \\
& & Massachusetts \\
& National Board Inspection Code, 2001 & The National Board of Boiler and \\
NB 23 & Edition & Pressure Vessel Inspectors, \\
& & Columbus, Ohio 23 \\
\hline
\end{tabular}

reciprocating engine exhaust gases, which typically range from 700 to $1,000^{\circ} \mathrm{F}$, can be used to produce high- or low-pressure steam or hot water. Exhaust heat-recovery units for reciprocating engines can be independent of the engine cooling system or combined into a single heat-recovery system. By effectively using heat-recovery equipment, it is possible to recover approximately 70 to $80 \%$ of the fuel energy from a reciprocating engine topping-cycle CHP system and use it to produce power and useful thermal energy. ${ }^{24}$

Exhaust from gas turbines and reciprocating engines contains significant quantities of recoverable heat, but the high-temperature service environment can create significant design challenges in material selection, structural performance, constructability, and reliability. Heat-recovery equipment that is suitable for high-temperature exposure is often relatively expensive, and maintenance, repair, and replacement costs should be assessed when considering heat-recovery equipment options. Although the overall efficiency of a CHP system is influenced by the effectiveness of heat-recovery equipment, some of the heat cannot be recovered for several reasons.

- For effective heat transfer, the temperature of the exhaust gases must remain above the temperature of the fluid to be heated. Temperature differences or pinch points used to design HRSGs typically range between 40 and $50^{\circ} \mathrm{F}$, but when the HRSG has sufficient heat transfer surface area, it is possible to reduce the pinch point to as low as $15^{\circ} \mathrm{F}$ (Ref. 25). Pinch point is defined as the minimum difference between the exhaust gas temperature and the saturated steam temperature into the HRSG evaporator. ${ }^{2}$

- To ensure proper flow of exhaust gases under all weather conditions, the temperature of the exhaust gas stream must remain sufficiently high to allow the gases to rise from the point of discharge into the surrounding atmosphere.

- For sulfur-bearing fuels, the exhaust gas temperature needs to remain sufficiently high to avoid condensation and thus minimize the potential for corrosion. Stack gas exit temperatures are generally maintained at $300^{\circ} \mathrm{F}$ or more, but temperatures as low as $150^{\circ} \mathrm{F}$ may be appropriate for some applications and fuels. 2,26

- The latent heat of the water vapor in the exhaust gases can only be recovered by reducing the exhaust gas temperature to below $212^{\circ} \mathrm{F}$. Although heat-recovery units can be designed to accomplish this level of heat transfer, the three previous constraints still apply.

The following discussions provide additional information about various types of unfired heatrecovery equipment used in industrial CHP applications. 


\subsubsection{Unfired Heat-Recovery Steam Generators}

Unfired HRSGs function as heat exchangers by using the thermal energy in hot exhaust gases to produce steam and hot water. Because hot exhaust gases effectively serve as fuel for these units, they are sometimes called waste heat-recovery boilers (WHRBs). The main application of a HRSG is waste heat recovery and steam production from gas turbine exhaust. ${ }^{26}$

Exhaust gas flow through a HRSG can be either horizontal or vertical. Horizontal designs occupy a larger footprint than vertical units, but vertical designs, which are more common in Europe, are less vulnerable to thermal cycling problems. Both HRSG configurations can be designed with multiple steamwater circuits to provide steam at different pressures. The construction of these circuits determines whether a unit is classified as a firetube or a watertube HRSG. Other components included in an unfired HRSG are the ductwork, steam drum, and stack. When communicating with HRSG manufacturers, it is important to define whether the operating mode will be steady state or cyclic because the mode of operation can affect the type of equipment selected and the design of individual components (Ref. 27). Both of these factors can potentially impact HRSG manufacturing costs.

In watertube HRSGs, water and steam are confined inside tubes that are exposed to hot exhaust gases. Because these gases are normally at or near atmospheric pressure, the structure that supports the tubes and confines the exhaust gases does not need to be designed as a pressure vessel. A watertube HRSG may have as many as three primary steam-water circuits. These circuits are known as the evaporator, superheat, and economizer.

1. The evaporator is the most important circuit. As water flows through the evaporator, it is heated to the saturation point corresponding to the operating pressure. The shape of the evaporator tubes defines the overall configuration of the HRSG. Common configurations include "D," "O," "A," "I," and horizontal tube layouts that may be assembled to create almost any size HRSG. Although it is possible to fabricate some watertube HRSGs in a shop and transport them to the site as a complete assembly, larger HRSGs must be fabricated as subassemblies, transported to the site, and then field erected.

2. The superheater is used to heat the saturated vapor that is produced in the steam drum. It is normally installed in front of the evaporator where the hottest part of the gas stream is located.

3. The economizer is used to preheat the feedwater being introduced to the system. It is normally located downstream from the evaporator where the exhaust gas temperature is lower.

To minimize potential corrosion damage to HRSG components, the economizer inlet temperature and the gas exit or stack temperature need to be controlled. If sulfur is present in the exhaust gas stream, the temperature of the exhaust gas should be maintained above the acid dew point to keep acid from condensing and causing corrosion of vulnerable materials. This temperature ranges from about $150^{\circ} \mathrm{F}$ for sulfur-free natural gas to $260^{\circ} \mathrm{F}$ for high-sulfur content fuels. ${ }^{26}$

In firetube HRSGs, hot exhaust gases flow through tubes that are surrounded by hot water and steam. The water and steam are confined by a leaktight housing that is designed as a pressure vessel. To minimize the material thickness of this pressure-retaining housing and thereby control material and fabrication costs, firetube HRSGs are generally physically smaller than watertube HRSGs.

Although HRSGs and boilers function as heat exchangers, the size of a HRSG is often larger than a conventional fuel-fired boiler because the lower exhaust gas temperatures require a greater heat transfer area, and there are practical limitations on flow restriction produced by a HRSG. Excessive flow resistance or back-pressure in the exhaust gas stream should be avoided because this can adversely affect gas turbine operation.

A HRSG is normally not an off-the-shelf item. Its design depends on factors such as the exhaust gas inlet temperature and the specified heat output. The selection and sizing of a HRSG usually involves 
providing the HRSG manufacturer with details of the exhaust gas flow and with the required temperature and pressure conditions of the heat output. Using this information, the HRSG manufacturer is then able to determine the quantity of heat that can be recovered and to estimate the discharge temperature of the exhaust gases.

Boiler owners and operators interested in generating electricity and additional steam with a gas turbine may want to consider adding an unfired HRSG to the CHP system. However, it should be noted that an unfired HRSG cannot produce steam unless the gas turbine is operating. Where this operational constraint is a concern, a supplementary burner that operates independently from the gas turbine can be added. Units with this feature are known as fired HRSGs. In a CHP system with a gas turbine and a fired HRSG, an alternative source of combustion air must be supplied to the HRSG when the gas turbine is not operating. Figure 4.1 shows the configuration of a HRSG that includes a supplementary duct burner. Additional information about supplementary fired HRSGs is provided in Sect. 4.2.1.

\subsubsection{Heat-Recovery Mufflers}

Although a HRSG can be used to recover heat from reciprocating engine exhaust, an exhaust gas heat exchanger known as a heat-recovery muffler is generally used for this purpose. Like HRSGs, heatrecovery mufflers are capable of generating hot water or low- or high-pressure steam from the hot exhaust gases that typically range from $700^{\circ} \mathrm{F}$ to $1,000^{\circ} \mathrm{F}$, but they are also designed to reduce exhaust gas noise. ${ }^{2}$

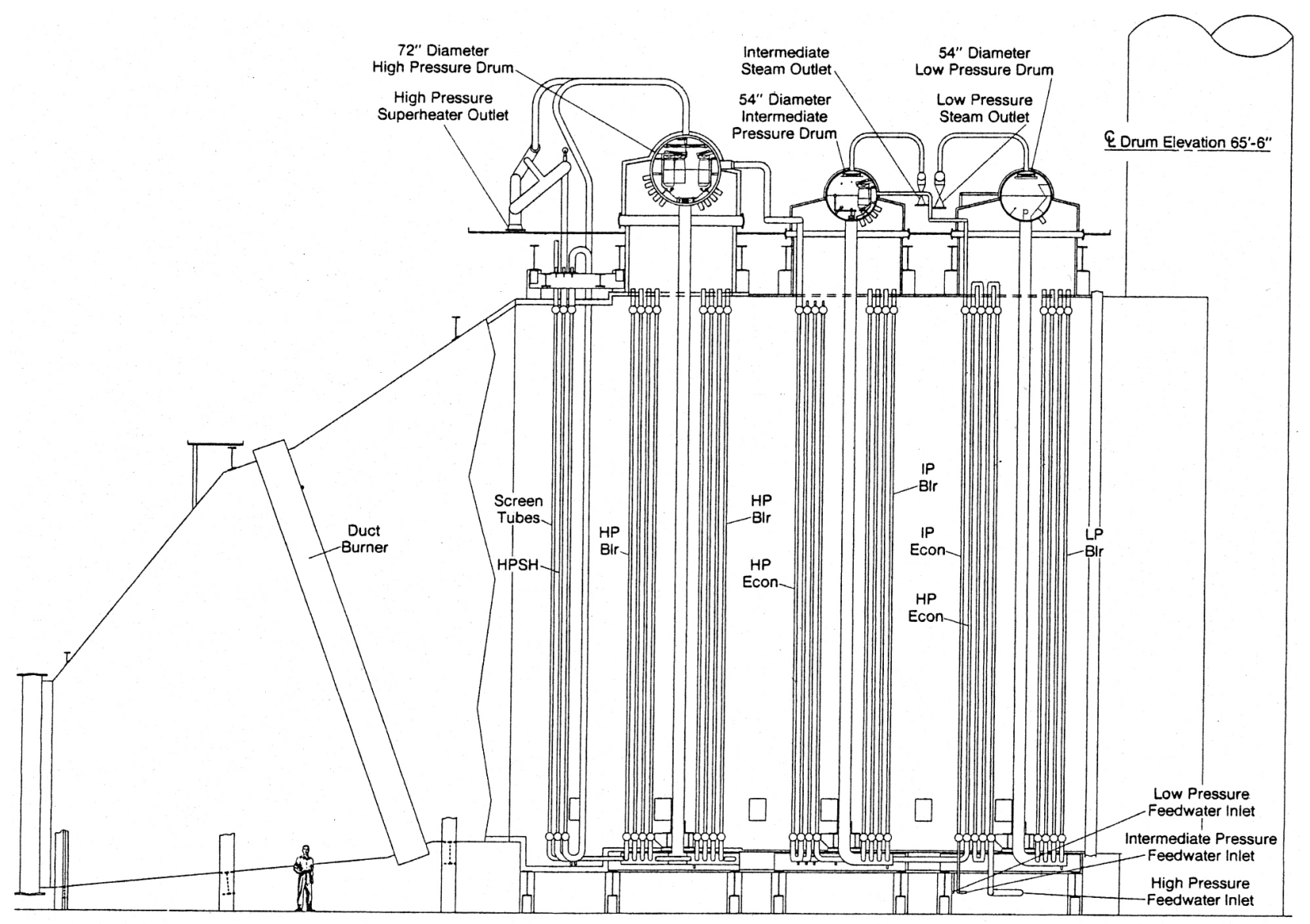

Fig. 4.1. HRSG. Source: Reprinted from Ref. 26. 
Exhaust gases from reciprocating engines can vary in temperature and composition. Consequently, heat exchanger and stack manufacturers need to be consulted to determine the minimum stack exit temperature. This temperature, which may be $300^{\circ} \mathrm{F}$ or more, influences the amount of heat that can be recovered and used for process applications.

During operation, heat-recovery mufflers should not create excessive back-pressure on the reciprocating engine because high back-pressure reduces engine capacity and increases the exhaust gas temperature. In selecting the location for a reciprocating engine, it is important to realize that sharp bends in the exhaust system piping can create excessive back-pressure and should be avoided.

Maintenance and cleaning of heat-recovery mufflers is important for effective heat recovery. Cleanout plugs, drains, and bypasses are often included to make maintenance easier. When used with oil-fired reciprocating engines, the muffler should include a soot blower to allow periodic cleaning to avoid soot buildup on exhaust gas heat exchanger surfaces. ${ }^{2}$

\subsubsection{Recuperators}

A recuperator is a gas-to-gas heat exchanger designed to extract heat from an exhaust gas stream and use it to increase the temperature of incoming combustion air. Terms used to describe specific types of recuperators include

- cast iron air heaters,

- heat pipe air heaters,

- plate air heaters,

- $\quad$ steam coil air heaters, and

- tubular air heaters. ${ }^{25,26}$

All recuperators rely on tubes or plates to continuously transfer heat from the outgoing exhaust gas to the incoming combustion air. These components are arranged to keep the two gas streams from mixing. Recuperators are available in a wide variety of sizes and configurations, but materials used in their construction must be carefully selected to avoid problems due to corrosion, erosion, fatigue, and hightemperature exposure. Recuperators are used in some gas turbine and most microturbine CHP systems. They use hot exhaust gases that exit the turbine to preheat the compressed air going to the combustion chamber thereby reducing the amount of fuel needed to heat the compressed air to the turbine inlet temperature. Depending on the operating parameters, recuperators can more than double efficiency.

Recuperators are expensive, and their costs are normally not justified unless the turbine operates for a large number of full-power hours per year and the cost of fuel is relatively high. One of the reasons recuperators are expensive is because they must be designed to operate in a high-temperature environment where large temperature differences create significant thermal stresses. Cyclic operation can also lead to joint fatigue and leakage resulting in loss of power and effectiveness.

To minimize possible confusion, note that recuperators are not the same as regenerators, which are discussed in Sect. 4.1.4. A recuperator is a gas-to-gas heat exchanger that separates the hot and cold flow streams using solid heat transfer surfaces. Although a regenerator is also a gas-to-gas heat exchanger, it includes an insulated container filled with metal or ceramic shapes capable of absorbing and storing relatively large amounts of thermal energy. Recuperators have no thermal energy storage capability. Depending on the operating parameters, recuperators can significantly improve energy efficiency. 


\subsubsection{Regenerators}

A regenerator is a gas-to-gas heat exchanger in which heat is transferred indirectly as a heat storage medium is alternately exposed to hot and cold flow streams. Periodic exposure to hot and cold flow streams can be accomplished either by rotary or valve-switching devices. During operation, a small but significant amount of air leakage occurs from one gas stream to the other.

In principle, combustion air supplied to a gas turbine can be preheated in a regenerator using heat recovered from the hot exhaust gases, but significant technical and economic issues are associated with this application. Difficulties in designing a regenerator that can reliably function in the high-temperature exhaust gas environment and constructing regenerators that are reasonably priced are major issues that severely restrict widespread use of regenerators in gas turbine CHP applications.

\subsubsection{Ebullient Cooling Systems}

Ebullient cooling systems are used to cool reciprocating engines. ${ }^{28}$ They use natural circulation of a boiling coolant such as treated water to remove heat. In operation, pressurized coolant enters the engine near the bottom where the heat causes part of the coolant to boil, generating two-phase flow. Because only part of the coolant boils, heat rejection occurs at a constant temperature with less thermal stress to the engine. The formation of bubbles lowers the density of the coolant and causes natural circulation to the top of the engine. Coolant at the engine outlet is maintained at saturated steam conditions and is usually limited to $250^{\circ} \mathrm{F}$ at a maximum pressure of $15 \mathrm{psig}$. Upon exiting the engine, the two-phase mixture flows to a steam separator where the steam is made available for process applications. Coolant is returned to the engine near saturation conditions and is generally only 2 to $3^{\circ} \mathrm{F}$ below the outlet temperature. Uniform temperature throughout the coolant circuit extends engine life and contributes to improved combustion efficiency. ${ }^{24}$

An ebullient cooling system is a rather simple engine cooling concept that eliminates the need for a coolant pump, but when a system leak results in loss of pressure, steam bubbles created in the engine expand rapidly, the coolant flow is reduced, and the engine overheats. Rapid loss of pressure can result in catastrophic engine failure. ${ }^{2}$

\subsubsection{Forced Circulation Cooling Systems}

Forced circulation cooling systems are commonly used to cool reciprocating engines by increasing the temperature of the circulating coolant with no phase change. Unlike ebullient cooling, forced circulation uses a coolant pump to move coolant through the closed-loop cooling system. Depending on the engine, forced circulation cooling systems can operate at coolant temperatures from 190 to $250^{\circ} \mathrm{F}$. Heat recovered by the coolant is transferred to another medium in either a liquid-to-air or a liquid-toliquid heat exchanger. Although somewhat more complex, a forced circulation cooling system provides greater engine overtemperature protection than a simpler ebullient cooling system.

\subsubsection{Aftercoolers}

Aftercoolers are gas-to-liquid (air-to-water) heat exchangers that remove heat from reciprocating engine turbochargers. Water supplied to an aftercooler is typically in the range of $85^{\circ} \mathrm{F}$ to $90^{\circ} \mathrm{F}$ (Ref. 2). As heat is removed from the turbocharger discharge, the temperature of the water flowing through the aftercooler increases to a maximum of about $160^{\circ} \mathrm{F}$. This lower quality heat is only suitable for increasing the temperature of boiler feedwater or for applications that require hot water. 


\subsubsection{Heat Exchangers}

Other types of heat exchangers besides those already described are sometimes used in CHP systems to transfer heat from gas-to-gas, gas-to-liquid, liquid-to-gas, and liquid-to-liquid. ${ }^{1,29}$ Common uses for heat exchangers in CHP systems include transfer of heat from

- hot water or steam to air for space heating applications,

- chilled water or refrigerant to air for space cooling applications,

- gas turbines or reciprocating engine exhaust to boiler feedwater or combustion air,

- fuel cell stack coolant to boiler feedwater or combustion air, and

- industrial processes to boiler feedwater or combustion air.

\subsection{FIRED UNITS}

Fired heat-recovery equipment serves two vital roles in CHP applications. As heat exchangers, the equipment extracts thermal energy exhausted from a heating source, and as combustion systems, the equipment uses chemical energy in fuel to produce additional thermal energy for the process. Two types of fired heat-recovery units are commonly used in industrial CHP applications. These units are known as supplementary fired HRSGs and ICI boilers. Options for using HRSGs and ICI boilers to recover waste heat from prime movers in CHP systems are summarized in Table 4.2.

Solid, liquid, and gaseous fuels are routinely burned in fired heat-recovery units to produce steam or hot water provided they are equipped with appropriate fuel handling, ash removal, and emission control equipment. Descriptions of fossil and nonfossil fuels that are burned in properly equipped ICI boilers and HRSGs are described in Table 4.3. The type and amount of emissions released into the atmosphere as a result of fuel combustion vary significantly depending on the type of fuel that is burned and the precombustion, combustion, and postcombustion emission control techniques that are applied. Emission control techniques that are effective in reducing $\mathrm{NO}_{\mathrm{x}}, \mathrm{SO}_{2}$, and $\mathrm{PM}$ emissions are provided in Tables 4.4, 4.5, and 4.6.

\subsubsection{Supplementary Fired Heat-Recovery Steam Generators}

High-temperature exhaust gases from gas turbines contain both sensible heat and an oxygen content of $15 \%$ or more. ${ }^{2}$ This oxygen-rich mixture can be used effectively as combustion air to burn fuel in a supplementary fired HRSG. Combustion equipment for firing the supplementary fuel is located within the ductwork that connects the gas turbine to the HRSG. This equipment, which is commonly referred to as a duct burner, is designed to raise the temperature of the gas turbine exhaust from less than $1,000^{\circ} \mathrm{F}$ to as high as $1,800^{\circ} \mathrm{F}$ (Ref. 33). The position of a duct burner in a large HRSG is shown in Fig. 4.1. Information about various HRSG designs is presented in Sect. 4.1.1.

Release of chemical energy in the supplementary fuel results in increased steam production compared to unfired units. Including a duct burner in a HRSG makes it possible to vary the amount of steam that is produced by controlling the supplementary fuel supply to the burner. This flexibility is especially important to industrial processes that have variable steam demand. 
Table 4.2. Options for using HRSGs and ICI boilers to recover waste heat

\begin{tabular}{|c|c|c|}
\hline CHP application & $\begin{array}{l}\text { Increase temperature of boiler } \\
\text { or HRSG feedwater }\end{array}$ & $\begin{array}{l}\text { Preheat boiler or HRSG } \\
\text { combustion air }\end{array}$ \\
\hline $\begin{array}{l}\text { Gas turbine and } \\
\text { microturbine topping- } \\
\text { and combined-cycle } \\
\text { systems } \\
\text { (See Sects. } 7.1 .2 \text { and } \\
\text { 7.1.5) }\end{array}$ & $\begin{array}{l}\text { Connect feedwater piping to gas turbine } \\
\text { exhaust heat exchanger to use waste } \\
\text { heat in exhaust gas to increase the } \\
\text { feedwater temperature. }\end{array}$ & $\begin{array}{l}\text { Use heat exchanger to transfer waste heat } \\
\text { in gas turbine exhaust to fresh } \\
\text { combustion air. } \\
\text { Mix fresh combustion air with gas turbine } \\
\text { exhaust, thereby using waste heat in } \\
\text { exhaust gases to preheat combustion } \\
\text { air. Gas turbine exhaust contains 15\% } \\
\text { or more oxygen and can support } \\
\text { combustion. }\end{array}$ \\
\hline $\begin{array}{l}\text { Reciprocating engine } \\
\text { topping systems } \\
\text { (See Sect. 7.1.3) }\end{array}$ & $\begin{array}{l}\text { Connect feedwater piping to heat- } \\
\text { recovery muffler, ebullient cooling } \\
\text { system, or forced-circulation cooling } \\
\text { system to use waste heat rejected by } \\
\text { engine to increase the feedwater } \\
\text { temperature. }\end{array}$ & $\begin{array}{l}\text { Use heat exchanger to transfer waste heat } \\
\text { in reciprocating engine exhaust to fresh } \\
\text { combustion air. } \\
\text { Mix fresh combustion air with } \\
\text { reciprocating engine exhaust, thereby } \\
\text { using waste heat in exhaust gases to } \\
\text { preheat combustion air provided } \\
\text { reciprocating engine exhaust does not } \\
\text { inhibit combustion. }\end{array}$ \\
\hline $\begin{array}{l}\text { Fuel cell topping systems } \\
\text { (See Sect. 7.1.4) }\end{array}$ & $\begin{array}{l}\text { Connect feedwater piping to fuel cell } \\
\text { heat exchanger to use heat rejected by } \\
\text { fuel cell to increase the feedwater } \\
\text { temperature. }\end{array}$ & $\begin{array}{l}\text { Use heat in fuel cell exhaust to preheat } \\
\text { combustion air. }\end{array}$ \\
\hline $\begin{array}{l}\text { Bottoming-cycle systems } \\
\text { (See Sect. 7.2) }\end{array}$ & $\begin{array}{l}\text { Connect feedwater piping to heat } \\
\text { exchanger to use waste heat rejected } \\
\text { by the industrial process heat source } \\
\text { to increase the feedwater temperature. } \\
\text { Modify boiler heat transfer surfaces to } \\
\text { use heat from the industrial process } \\
\text { heat source to produce steam. }\end{array}$ & $\begin{array}{l}\text { Use waste heat from industrial process } \\
\text { heat source to preheat combustion air. }\end{array}$ \\
\hline $\begin{array}{l}\text { Gas-turbine-based } \\
\text { trigeneration systems } \\
\text { (See Sect. 7.4) }\end{array}$ & $\begin{array}{l}\text { Connect feedwater piping to gas turbine } \\
\text { exhaust heat exchanger to use waste } \\
\text { heat in exhaust gas to increase the } \\
\text { feedwater temperature. }\end{array}$ & $\begin{array}{l}\text { Use heat exchanger to transfer waste heat } \\
\text { in gas turbine exhaust to fresh } \\
\text { combustion air. } \\
\text { Mix fresh combustion air with gas turbine } \\
\text { exhaust, thereby using waste heat in } \\
\text { exhaust gases to preheat combustion } \\
\text { air. Gas turbine exhaust contains 15\% } \\
\text { or more oxygen and can support } \\
\text { combustion. }\end{array}$ \\
\hline
\end{tabular}


Table 4.3. Fuels commonly burned to generate hot water or steam

\begin{tabular}{|c|c|}
\hline Fuel & Description \\
\hline By-product/waste & $\begin{array}{l}\text { Any liquid or gaseous substance produced at chemical manufacturing plants or petro- } \\
\text { leum refineries (except natural gas, distillate oil, or residual oil) and combusted in a } \\
\text { steam generating unit for heat recovery or for disposal }\end{array}$ \\
\hline Biomass & $\begin{array}{l}\text { Organic matter that is used as fuel is called biomass; biomass is a nonfossil fuel that } \\
\text { includes materials such as wood, bagasse, nut hulls, rice hulls, corncobs, coffee } \\
\text { grounds, and tobacco stems }\end{array}$ \\
\hline Coal & $\begin{array}{l}\text { Coal is a brown-to-black combustible sedimentary rocklike material composed princi- } \\
\text { pally of consolidated and chemically altered plant material that grew in prehistoric } \\
\text { forests; it includes all solid fuel classified as anthracite, bituminous, subbituminous, } \\
\text { or lignite coal, coal refuse, or petroleum coke. }\end{array}$ \\
\hline Coal refuse & $\begin{array}{l}\text { Waste products of coal mining, physical coal cleaning, and coal preparation operations } \\
\text { containing coal, matrix material, clay, and other organic and inorganic materials. }\end{array}$ \\
\hline Distillate oil & $\begin{array}{l}\text { Fuel oils that contain } 0.05 \mathrm{wt} \% \text { nitrogen or less and comply with the specifications for } \\
\text { fuel oil Nos. } 1 \text { and } 2 \text { as defined in ASTM D } 396 \text { (Ref. 20) }\end{array}$ \\
\hline MSW and RDF & $\begin{array}{l}\text { Refuse, more than } 50 \% \text { of which is waste containing a mixture of paper, wood, yard } \\
\text { waste, food wastes, plastics, leather, rubber, and other noncombustible materials such } \\
\text { as metal, glass, and rock, which are usually removed prior to combustion }\end{array}$ \\
\hline Natural gas & $\begin{array}{l}\text { A naturally occurring mixture of hydrocarbon gases found in geologic formations } \\
\text { beneath the earth's surface, of which the principal constituent is methane, or LP gas } \\
\text { as defined in ASTM D } 1835 \text { (Ref. 30) }\end{array}$ \\
\hline Oil & $\begin{array}{l}\text { Crude oil or petroleum or a liquid fuel derived from crude oil or petroleum, including } \\
\text { distillate and residual oil }\end{array}$ \\
\hline Propane & Propane is a heavy gaseous fossil fuel processed from crude petroleum and natural gas \\
\hline Residual oil & $\begin{array}{l}\text { Crude oil and fuel oil Nos. } 1 \text { and } 2 \text { that have nitrogen content greater than } 0.05 \text { wt \%, } \\
\text { and all fuel oil Nos. 4, 5, and } 6 \text { as defined in ASTM D } 396 \text { (Ref. 20) }\end{array}$ \\
\hline Solvent-derived fuel & $\begin{array}{l}\text { Any solid, liquid, or gaseous fuel derived from solid fuel for the purpose of creating } \\
\text { useful heat and includes, but is not limited to, solvent-refined coal, liquefied coal, } \\
\text { and gasified coal }\end{array}$ \\
\hline TDF & $\begin{array}{l}\text { TDF, as described in ASTM D } 6700 \text { (Ref. 31), consists of whole scrap tires in a } \\
\text { chipped form for use as fuel }\end{array}$ \\
\hline Very low sulfur oil & $\begin{array}{l}\text { Oil that contains no more than } 0.5 \mathrm{wt} \% \text { sulfur and that, when combusted without } \mathrm{SO}_{2} \\
\text { emission control, has a } \mathrm{SO}_{2} \text { emissions rate equal to or less than } 215-\mathrm{ng} / \mathrm{J} \\
(0.5-\mathrm{lb} / \mathrm{MMBtu}) \text { heat output }\end{array}$ \\
\hline Wood & $\begin{array}{l}\text { Wood, wood residue, bark, or any derivative fuel or residue thereof, in any form, } \\
\text { including, but not limited to, sawdust, sander dust, wood chips, scraps, slabs, } \\
\text { millings, shavings, and processed pellets made from wood or other forest products }\end{array}$ \\
\hline Wood residue & $\begin{array}{l}\text { Bark, sawdust, slabs, chips, shavings, mill trim, and other wood products derived from } \\
\text { wood processing and forest management operations }\end{array}$ \\
\hline
\end{tabular}

Source: Ref. 32. 
Table 4.4. Techniques for controlling emissions before combustion

\begin{tabular}{|c|c|c|}
\hline Emission & Control technique & Description \\
\hline $\mathrm{NO}_{\mathrm{X}}$ & $\begin{array}{l}\text { Switch to fuel with a low- } \\
\text { nitrogen content }\end{array}$ & $\begin{array}{l}\text { Removing nitrogen from fuel prior to combustion is generally not } \\
\text { practical, but switching to fuel with a low-nitrogen content is an } \\
\text { effective technique for reducing } \mathrm{NO}_{\mathrm{x}} \text { emissions. The level of nitrogen } \\
\text { in natural gas is generally low, and fuel oil typically has a lower } \\
\text { nitrogen content than coal. }\end{array}$ \\
\hline \multirow[t]{2}{*}{$\mathrm{SO}_{2}$} & $\begin{array}{l}\text { Switch to fuel with a low- } \\
\text { sulfur content }\end{array}$ & $\begin{array}{l}\text { Switching from high- to low-sulfur fuel is an effective technique for } \\
\text { reducing } \mathrm{SO}_{2} \text { emissions. }\end{array}$ \\
\hline & Perform beneficiation & $\begin{array}{l}\text { Cleaning solid fuel such as coal by mechanical, chemical, or other means } \\
\text { is an effective technique for maximizing the quality of the fuel. } \\
\text { Eliminating noncombustible sulfur-bearing materials like pyrites and } \\
\text { sulfates prior to combustion can reduce } \mathrm{SO}_{2} \text { emissions. } \\
\text { Refining petroleum to produce distillate oil is an effective processing } \\
\text { technique that decreases the sulfur content of the fuel. Removing sulfur- } \\
\text { bearing compounds prior to combustion is an effective technique for } \\
\text { reducing } \mathrm{SO}_{2} \text { emissions. } \\
\text { Processing natural gas by removing hydrogen sulfide eliminates the } \\
\text { possibility of } \mathrm{SO}_{2} \text { emissions during combustion. }\end{array}$ \\
\hline \multirow[t]{2}{*}{ PM } & $\begin{array}{l}\text { Switch to fuel with a low- } \\
\text { ash content }\end{array}$ & $\begin{array}{l}\text { Switching from solid fuel such as coal, which has a high-ash content, to } \\
\text { oil or natural gas is an effective technique for reducing PM emissions. }\end{array}$ \\
\hline & Perform beneficiation & $\begin{array}{l}\text { Cleaning solid fuel such as coal by mechanical, chemical, or other means } \\
\text { is an effective technique for maximizing the quality of the fuel. } \\
\text { Eliminating noncombustible, ash-producing materials like metals, sand, } \\
\text { glass, and rock prior to combustion can be a very effective technique } \\
\text { for reducing PM emissions. } \\
\text { Refining petroleum into distillate oil is an effective processing technique } \\
\text { that decreases the ash content of the fuel. Removing ash prior to } \\
\text { combustion is an effective technique for reducing PM emissions. }\end{array}$ \\
\hline
\end{tabular}

Table 4.5. Techniques for controlling emissions during combustion

\begin{tabular}{|c|c|c|}
\hline Emission & Control technique & Description \\
\hline \multirow[t]{3}{*}{$\mathrm{NO}_{\mathrm{x}}$} & $\begin{array}{l}\text { Operational modifications } \\
\text { - } \quad \text { Oxygen trim (OT) } \\
\text { - } \quad \text { Burner tuning (BT) } \\
\text { - } \quad \text { Low excess air (LEA) }\end{array}$ & $\begin{array}{l}\text { Minimizing the amount of excess oxygen supplied to the boiler can } \\
\text { reduce thermal } \mathrm{NO}_{\mathrm{x}} \text { formation. OT, } \mathrm{BT} \text {, and LEA can sometimes be } \\
\text { used to successfully optimize the operation of burners by } \\
\text { minimizing excess air without excessively increasing unburned fuel. }\end{array}$ \\
\hline & $\begin{array}{l}\text { Staged combustion air (SCA) } \\
\text { - } \text { Burners out of service } \\
\text { (BOOS) } \\
\text { - } \text { Biased firing (BF) } \\
\text { - Overfire air (OFA) }\end{array}$ & $\begin{array}{l}\text { Staging the amount of combustion air that is introduced into the } \\
\text { burner zone can reduce the flame temperature and thereby reduce } \\
\text { thermal } \mathrm{NO}_{\mathrm{x}} \text { formation. For multiburner units, taking certain BOOS } \\
\text { can be an effective technique for staging combustion. Biasing the } \\
\text { fuel flow to different burners can also be an effective technique. } \\
\text { Injecting air into the boiler above the top burner level through OFA } \\
\text { ports can decrease the primary flame zone oxygen level and } \\
\text { produce an air-rich secondary zone where combustion is completed. }\end{array}$ \\
\hline & $\begin{array}{l}\text { Steam or water injection } \\
\quad(\mathrm{SI} / \mathrm{WI})\end{array}$ & $\begin{array}{l}\text { Quenching the combustion process with WI or SI can lower the peak } \\
\text { flame temperature and result in reduced thermal } \mathrm{NO}_{\mathrm{x}} \text { production. }\end{array}$ \\
\hline
\end{tabular}


Table 4.5. (continued)

\begin{tabular}{|c|c|c|}
\hline Emission & Control technique & Description \\
\hline & Flue gas recirculation (FGR) & $\begin{array}{l}\text { Recirculating a portion of the flue gas to the combustion zone can } \\
\text { lower the peak flame temperature and result in reduced thermal } \\
\mathrm{NO}_{\mathrm{x}} \text { production. }\end{array}$ \\
\hline & Reducing air preheat (RAP) & $\begin{array}{l}\text { Reducing the air preheat temperature when preheat is used can lower } \\
\text { the peak flame temperature and result in reduced thermal } \mathrm{NO}_{\mathrm{X}} \\
\text { production. }\end{array}$ \\
\hline & Low-NO ${ }_{\mathrm{x}}$ burner (LNB) & $\begin{array}{l}\text { Using LNBs can reduce } \mathrm{NO}_{\mathrm{X}} \text { formation through careful control of the } \\
\text { fuel-air mixture during combustion. Control techniques used in } \\
\text { LNBs include staged air, staged fuel, and FGR, as well as other } \\
\text { methods that effectively lower the flame temperature. }\end{array}$ \\
\hline & $\begin{array}{l}\text { Fuel-induced recirculation } \\
\text { (FIR) }\end{array}$ & $\begin{array}{l}\text { An } \mathrm{NO}_{\mathrm{x}} \text { reduction technique applicable to boilers that burn gaseous } \\
\text { fuels. FIR is similar to FGR except a portion of the flue gas is } \\
\text { mixed with natural gas instead of combustion air. The effect of this } \\
\text { mixture on the combustion process is to reduce the peak flame } \\
\text { temperature. }\end{array}$ \\
\hline & Natural gas reburning (NGR) & $\begin{array}{l}\text { Introducing natural gas downstream of the main fuel combustion zone } \\
\text { can reduce } \mathrm{NO}_{\mathrm{x}} \text { emissions. The natural gas combustion products } \\
\text { strip oxygen from } \mathrm{NO}_{\mathrm{x}} \text { molecules produced by combustion of the } \\
\text { primary fuel, thereby creating harmless molecular nitrogen. }\end{array}$ \\
\hline \multirow[t]{2}{*}{$\mathrm{SO}_{2}$} & $\begin{array}{l}\text { Limestone or dolomite can be } \\
\text { introduced into fluidized } \\
\text { bed combustion (FBC) } \\
\text { boilers to serve as a sulfur- } \\
\text { capture sorbent }\end{array}$ & $\begin{array}{l}\text { Controlling } \mathrm{SO}_{2} \text { emissions during combustion in an } \mathrm{FBC} \text { boiler can be } \\
\text { accomplished by feeding limestone or dolomite into the bed where } \\
\text { calcium oxide reacts with } \mathrm{SO}_{2} \text { for a sulfur-laden sorbent that is } \\
\text { removed as either bottom or fly ash. }\end{array}$ \\
\hline & $\begin{array}{l}\text { Except for } \mathrm{FBC} \text { boilers, no } \\
\text { techniques are available to } \\
\text { effectively remove } \mathrm{SO}_{2} \\
\text { during combustion }\end{array}$ & $\begin{array}{l}\text { Reducing } \mathrm{SO}_{2} \text { emissions can be accomplished by either removing } \\
\text { sulfur compounds from the fuel prior to combustion or employing } \\
\text { flue gas desulfurization (FGD) techniques after combustion (see } \\
\text { Tables } 4.4 \text { and 4.6). }\end{array}$ \\
\hline \multirow[t]{2}{*}{$\mathrm{PM}$} & Operational modifications & $\begin{array}{l}\text { Unburned carbon particles can sometimes be reduced by adjusting the } \\
\text { combustion process or changing certain fuel properties such as } \\
\text { fineness. }\end{array}$ \\
\hline & $\begin{array}{l}\text { No techniques are available to } \\
\text { effectively remove non- } \\
\text { combustible PM during } \\
\text { combustion }\end{array}$ & $\begin{array}{l}\text { Controlling noncombustible PM emissions is most effectively } \\
\text { accomplished after combustion by removing fine particles dispersed } \\
\text { in the flue gas (see Table 4.6). }\end{array}$ \\
\hline
\end{tabular}


Table 4.6. Techniques for controlling emissions after combustion

\begin{tabular}{|c|c|c|}
\hline Emission & Control technique & Description \\
\hline \multirow[t]{3}{*}{$\mathrm{NO}_{\mathrm{x}}$} & $\begin{array}{l}\text { Selective catalytic reduction } \\
\quad(\mathrm{SCR})\end{array}$ & $\begin{array}{l}\text { Reducing } \mathrm{NO}_{\mathrm{x}} \text { emissions can be accomplished using the SCR } \\
\text { technique in which a reductant (ammonia gas) is injected in the } \\
\text { flue-gas stream before it passes through a catalyst bed. This } \\
\text { technique disassociates } \mathrm{NO}_{\mathrm{x}} \text { to nitrogen gas and water vapor. }\end{array}$ \\
\hline & $\begin{array}{l}\text { Selective noncatalytic } \\
\text { reduction (SNCR) }\end{array}$ & $\begin{array}{l}\text { Reducing } \mathrm{NO}_{\mathrm{x}} \text { emissions can also be accomplished using the } \\
\mathrm{SNCR} \text { technique in which a reagent is injected in the flue-gas } \\
\text { stream where } \mathrm{NO}_{\mathrm{x}} \text { is reduced to nitrogen gas and water vapor. } \\
\text { Ammonia gas and aqueous urea are the two reagents most often } \\
\text { used for this purpose. }\end{array}$ \\
\hline & SCONOX $^{\mathrm{TM}}$ & $\begin{array}{l}\text { Reducing } \mathrm{NO}_{\mathrm{x}} \text { emissions is now possible using the } \mathrm{SCONOX} \text { TM } \\
\text { Catalytic Absorption System developed by Goal Line } \\
\text { Environmental Technologies, LLC. This system uses a } \\
\text { potassium carbonate }\left(\mathrm{K}_{2} \mathrm{CO}_{3}\right) \text { coated catalyst to reduce oxide of } \\
\text { nitrogen emissions. The catalyst oxidizes } \mathrm{CO} \text { to } \mathrm{CO}_{2} \text { and } \mathrm{NO} \text { to } \\
\mathrm{NO}_{2} \text {. The } \mathrm{CO}_{2} \text { is exhausted, while the } \mathrm{NO}_{2} \text { absorbs onto the } \\
\text { catalyst to form potassium nitrites }\left(\mathrm{KNO}_{2}\right) \text { and potassium } \\
\text { nitrates }\left(\mathrm{KNO}_{3}\right) \text {. Dilute hydrogen gas is passed periodically } \\
\text { across the surface of the catalyst to regenerate the } \mathrm{K}_{2} \mathrm{CO}_{3} \\
\text { coating. The regeneration cycle converts the } \mathrm{KNO}_{2} \text { and } \mathrm{KNO}_{3} \\
\text { to } \mathrm{K}_{2} \mathrm{CO}_{3} \text {, water, and elemental nitrogen. The } \mathrm{K}_{2} \mathrm{CO}_{3} \text { is thereby } \\
\text { made available for further absorption, and the water and } \\
\text { nitrogen are exhausted. }\end{array}$ \\
\hline \multirow[t]{4}{*}{$\mathrm{SO}_{2}$} & \multirow{4}{*}{$\begin{array}{l}\text { FGD using } \\
\text { - nonregenerable } \\
\text { (throwaway) processes } \\
\text { - regenerable (recovery) } \\
\text { processes }\end{array}$} & $\begin{array}{l}\text { Removing } \mathrm{SO}_{2} \text { from flue gas is most often accomplished in a wet } \\
\text { scrubber where the flue gas is contacted with an aqueous slurry } \\
\text { of lime or limestone. Reactions between the lime or limestone } \\
\text { and the } \mathrm{SO}_{2} \text { produce a calcium salt waste product. }\end{array}$ \\
\hline & & $\begin{array}{l}\text { Circulating a sodium-based compound through a scrubber will } \\
\text { also reduce } \mathrm{SO}_{2} \text { emissions. Effluent from the scrubber is then } \\
\text { mixed with lime or limestone to produce a calcium-sulfur waste } \\
\text { product. }\end{array}$ \\
\hline & & $\begin{array}{l}\text { Injecting a calcium-based sorbent such as lime into the flue-gas } \\
\text { steam is also an effective technique for reducing } \mathrm{SO}_{2} \\
\text { emissions. Methods such as spray absorption, spray drying, or } \\
\text { semiwet scrubbing produce a dry waste product that is collected } \\
\text { along with the PM. }\end{array}$ \\
\hline & & $\begin{array}{l}\text { Removing } \mathrm{SO}_{2} \text { dispersed in flue gas can be accomplished by vari- } \\
\text { ous advanced FGD techniques. Resulting sulfur compounds } \\
\text { that have value include gypsum (wallboard), sulfur, and sulfuric } \\
\text { acid. }\end{array}$ \\
\hline $\mathrm{PM}$ & Cyclone separator & $\begin{array}{l}\text { Separating PM dispersed in flue gas can be accomplished using a } \\
\text { mechanical collector known as a cyclone. Separation is } \\
\text { achieved as the particles are subjected to centrifugal and gravi- } \\
\text { tational forces. Inside the cyclone, solid particles exit through } \\
\text { an opening in the bottom, and the cleaned flue gas exits through } \\
\text { an opening in the top. }\end{array}$ \\
\hline
\end{tabular}


Table 4.6. (continued)

\begin{tabular}{|c|c|c|}
\hline \multirow{2}{*}{\multicolumn{2}{|c|}{$\begin{array}{l}\text { Control technique } \\
\text { Wet scrubber }\end{array}$}} & Description \\
\hline & & $\begin{array}{l}\text { Removing PM dispersed in flue gas can be accomplished using a } \\
\text { wet scrubber in which the particles impact water droplets. A } \\
\text { spray tower is one type of low-pressure-drop wet scrubber, and } \\
\text { a venturi-type scrubber is a high-pressure-drop wet scrubber. }\end{array}$ \\
\hline & $\begin{array}{l}\text { Electrostatic precipitator } \\
\text { (ESP) }\end{array}$ & $\begin{array}{l}\text { Charging particles that are dispersed in flue gas with electrical } \\
\text { energy is an effective technique for reducing PM emissions. In } \\
\text { a dry ESP, the particles are electrically charged and then } \\
\text { attracted to a collecting surface rather than discharged into the } \\
\text { atmosphere. Particles that accumulate on the collecting surfaces } \\
\text { are periodically removed by sonic horns or mechanical rappers } \\
\text { that dislodge the dust cake and allow it to fall into a hopper } \\
\text { located at the bottom of the ESP. In a wet ESP, a liquid is used } \\
\text { to clean the collecting surfaces. Wet ESPs find their greatest } \\
\text { use in applications where collection of submicron particles is } \\
\text { desirable (Ref. 34). }\end{array}$ \\
\hline & Fabric filter (baghouse) & $\begin{array}{l}\text { Collecting PM dispersed in flue gas can be accomplished by } \\
\text { allowing the particle-laden gas to flow through a fabric filter. } \\
\text { These fine-mesh filters are located inside a gas-tight structure } \\
\text { known as a baghouse. }\end{array}$ \\
\hline & $\begin{array}{l}\text { Electrostatically stimulated } \\
\text { fabric filter (ESFF) }\end{array}$ & $\begin{array}{l}\text { Removing PM dispersed in flue gas can also be accomplished } \\
\text { using ESFF technology. This technique, which has been } \\
\text { patented by EPA, uses high-voltage discharge electrodes in } \\
\text { combination with fabric filters. It is fundamentally an } \\
\text { electrostatic precipitator that uses fabric filters instead of } \\
\text { collecting plates. This technique results in collection } \\
\text { efficiencies that are higher than those achieved by either current } \\
\text { fabric filter or electrostatic precipitator technology. }\end{array}$ \\
\hline
\end{tabular}

Most supplementary fired HRSGs burn natural gas, but designs are available for burning other gaseous or liquid fuels. To minimize $\mathrm{NO}_{\mathrm{x}}$ emissions, low $\mathrm{NO}_{\mathrm{x}}$ burners with guaranteed emissions levels as low as $0.08 \mathrm{lb} / \mathrm{MMBtu}_{\mathrm{NO}}$ can be used as duct burners. ${ }^{33}$

Unlike gas turbines, reciprocating engines do not operate with large quantities of excess air, so the oxygen content of the exhaust gases generally does not exceed $8 \%$. With an oxygen content this low, recovering heat from reciprocating engine exhaust gases in a supplementary fired HRSG is generally not possible because the exhaust gases are incapable of supporting additional combustion. ${ }^{2}$ Heat recovery from reciprocating engines can be achieved using a heat-recovery muffler that functions as an unfired heat exchanger described in Sect. 4.1.2.

\subsubsection{Industrial, Commercial, and Institutional Boilers}

Boilers for ICI use are designed primarily to use the chemical energy in fuel to raise the temperature of water so that it can be used for process and heating applications. ${ }^{35}$ In CHP applications, ICI boilers can also function as fired heat-recovery units designed to use heat rejected from prime movers and other heating sources to produce more steam with less fuel. When used in this capacity, ICI boilers are often characterized as waste heat-recovery boilers.

In general, ICI boilers are smaller and more versatile than most power boilers used by utilities to produce electricity. They are manufactured in a wide range of sizes to burn coal, oil, natural gas, and 
biomass as well as other fuels and fuel combinations. Most ICI boilers are classified as either watertube or firetube boilers, but other designs such as cast iron, coil-type, and tubeless (steel shell) boilers are also produced. ${ }^{32}$

Firetube boilers consist of a series of straight tubes that are housed inside a water-filled outer shell. The tubes are arranged so that hot combustion gases flow through the tubes. As hot gases flow through the tubes, they heat the water that surrounds the tubes. The water is confined by the outer shell of the boiler that is designed as a pressure vessel. To avoid the need for excessively thick materials, firetube boilers are used for lower-pressure applications. Firetube boilers are subdivided into three groups. Horizontal return tubular (HRT) boilers typically have horizontal, self-contained firetubes with a separate combustion chamber. Scotch, Scotch marine, or shell boilers have the firetubes and combustion chamber housed within the same shell. Firebox boilers have a water-jacketed firebox and employ, at most, three passes of combustion gases. Boiler configurations for each type are shown in Figs. 4.2 to 4.4, respectively.

Watertube boilers are designed to circulate hot combustion gases around the outside of a large number of water-filled tubes. The tubes extend between an upper header, called a steam drum, and one or more lower headers or drums. In older designs, the tubes are either straight or bent into simple shapes. Newer boilers have tubes with complex and diverse bends. Because the pressure is confined inside the tubes, watertube boilers can be fabricated in larger sizes and used for higher-pressure applications. Small watertube boilers, which have one and sometimes two burners, are generally fabricated and supplied as packaged units. Because of their size and weight, large watertube boilers are often fabricated in pieces and assembled in the field. Configurations for packaged and field-erected watertube boilers are shown in Figs. 4.5 and 4.6, respectively.

Heat rejected by a prime mover can be used to increase the temperature of the boiler feedwater or preheat the combustion air that is supplied to the boiler. When an ICI boiler is used in a CHP system, it is important to recognize that changes to the boiler design, piping and ductwork systems, boiler control scheme, or emission control and monitoring systems may be necessary for it to function effectively as a fired heat-recovery unit. Options for using ICI boilers for waste heat recovery are summarized in Table 4.2.

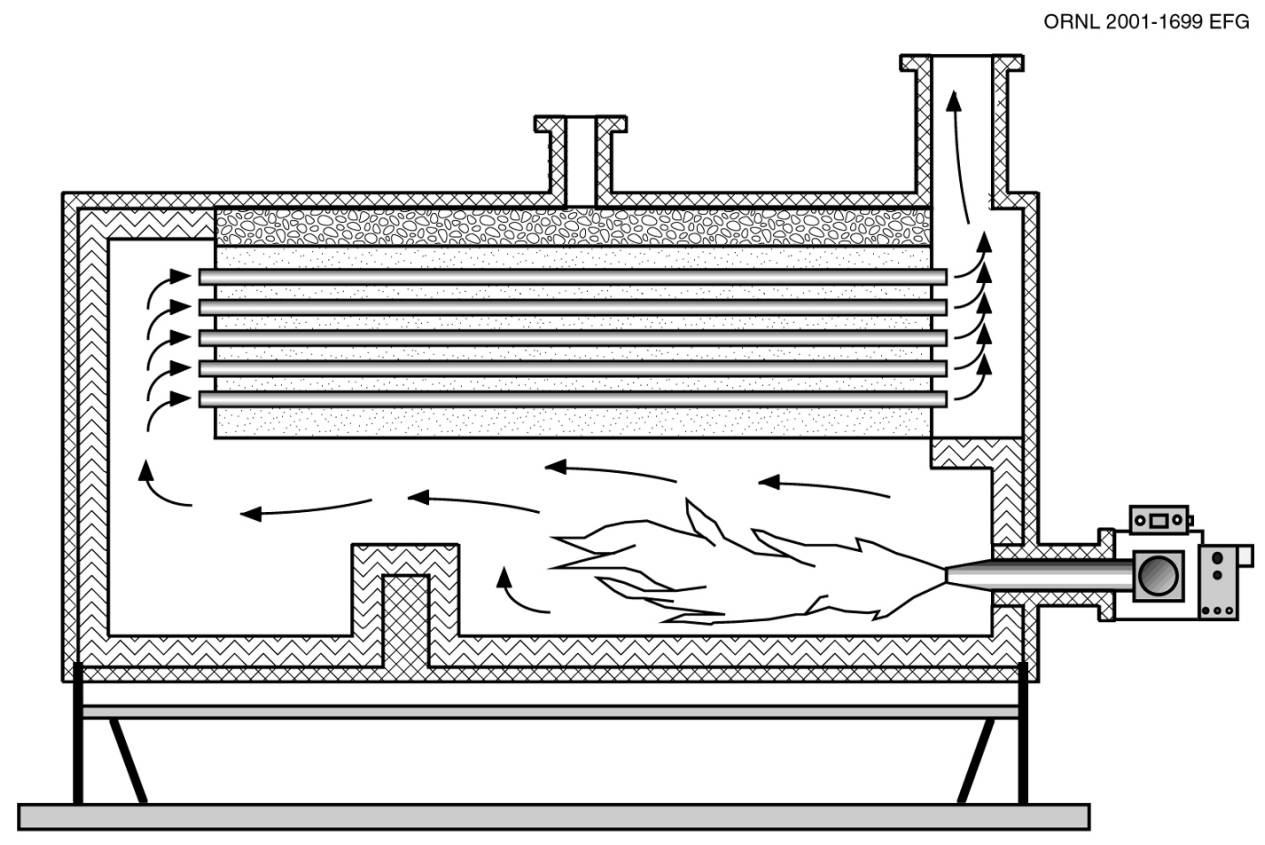

Fig. 4.2. Configuration of HRT firetube boiler. 


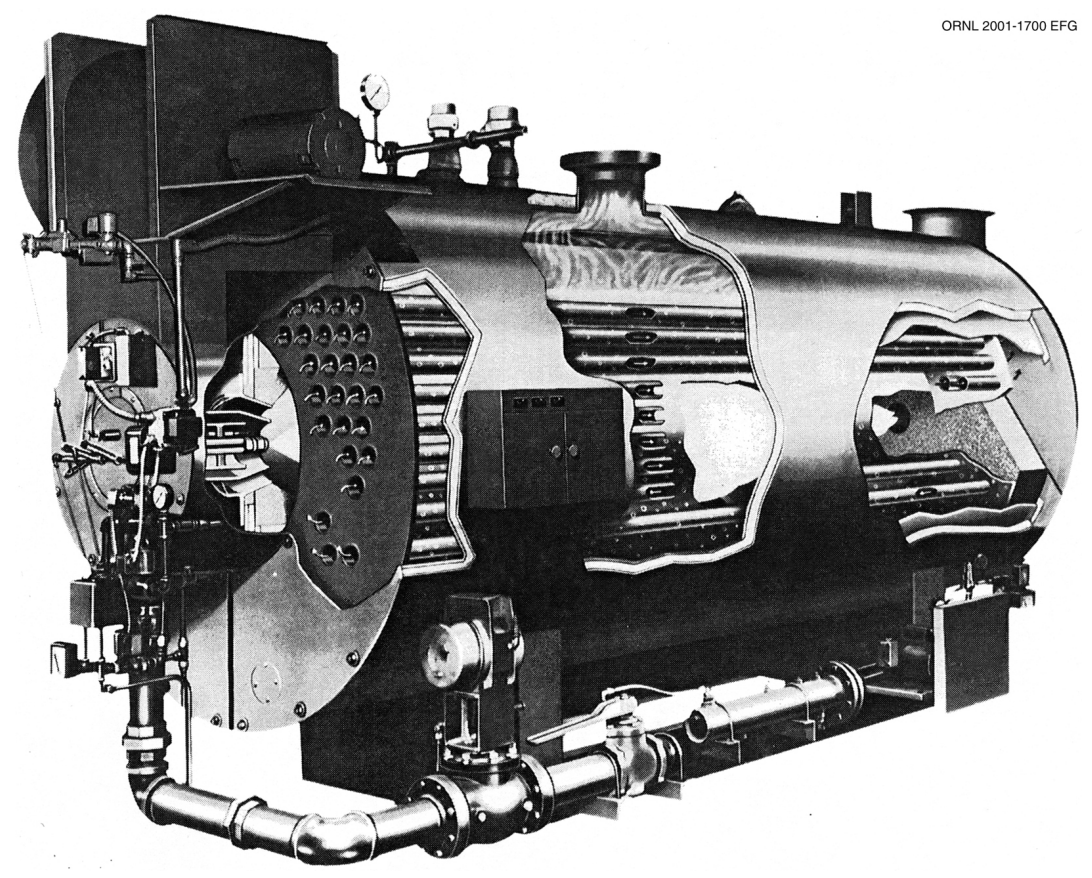

Fig. 4.3. Configuration of Scotch package firetube boiler. Source: Reprinted from Ref. 36.

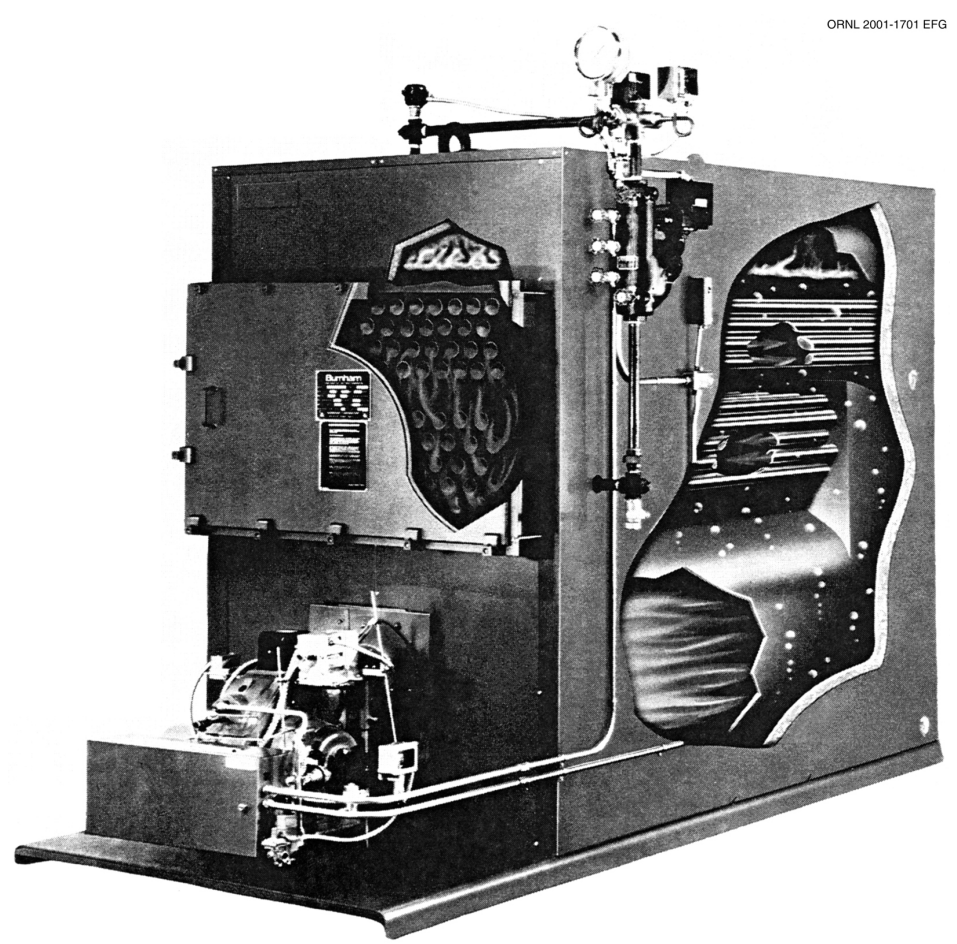

Fig. 4.4. Configuration of firebox firetube boiler. Source: Reprinted from Ref. 36. 


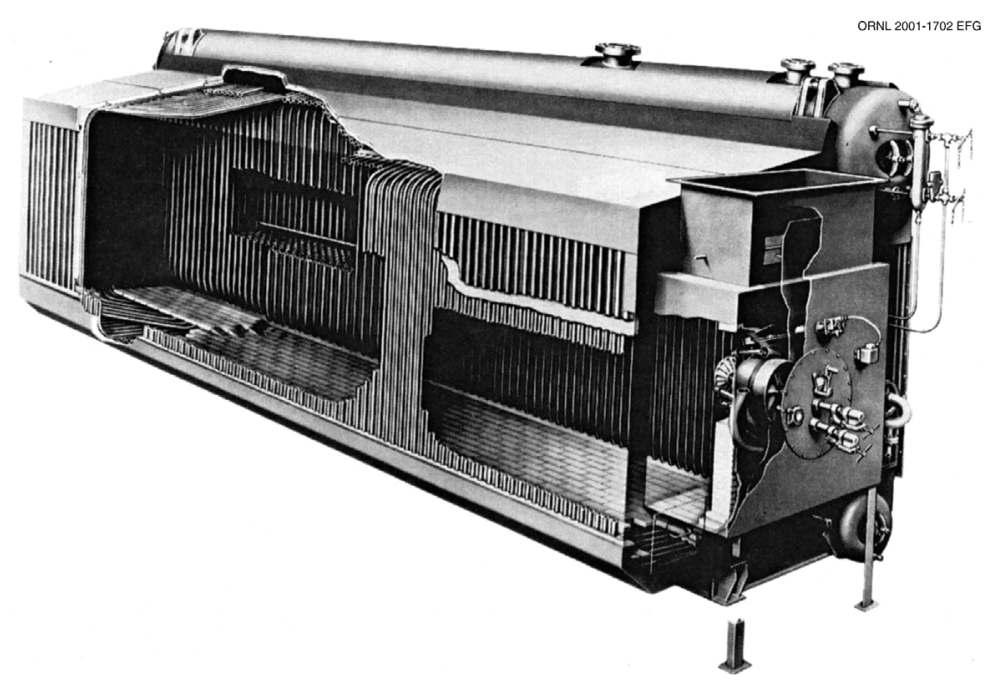

Fig. 4.5. Configuration of package watertube boiler. Source: Reprinted from Ref. 36.

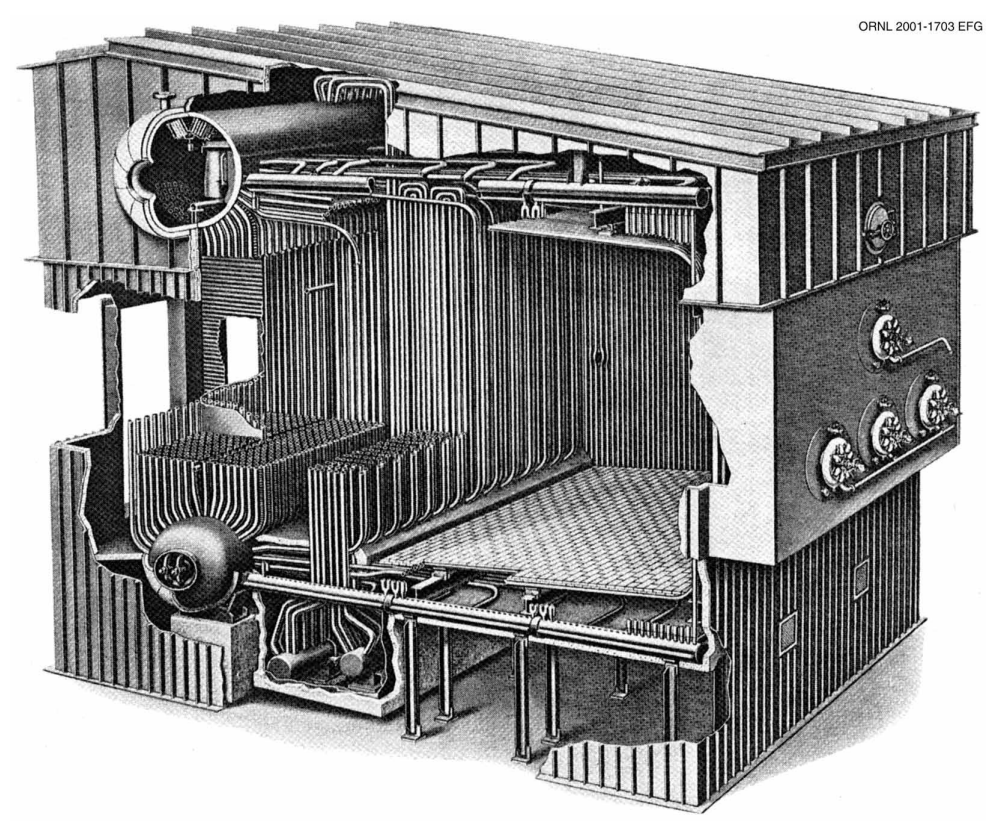

Fig. 4.6. Configuration of field-erected watertube boiler. Source: Reprinted from Ref. 36.

Complex changes in steam supply and boiler feedwater return systems may be required for an ICI boiler to effectively use heat rejected from a prime mover. For example, specially designed ductwork may be required to use gas turbine exhaust as combustion air for the boiler, and additional piping may need to be constructed to use hot water from a fuel cell to increase the temperature of boiler feedwater. In some cases, it may not be technically or economically feasible to change the configuration of an existing boiler so that it can function as a fired heat-recovery unit. This is especially true when additional heat transfer surfaces must be added inside a boiler to create independent loops for closed-cycle operations. 


\subsection{REFERENCES}

1. "Heat Exchangers," Chapter 43, ASHRAE Handbook-HVAC Systems and Equipment, American Society of Heating, Refrigerating and Air-Conditioning Engineers, Inc., Atlanta, Georgia, July 6, 2000.

2. J. A. Orlando, Cogeneration Design Guide, American Society of Heating, Refrigerating and AirConditioning Engineers, Inc., Atlanta, Georgia, 1996.

3. Heat Recovery Steam Generators, API Publication 534, 1st ed., American Petroleum Institute, Washington, D.C., 1995.

4. Instrumentation and Control Systems for Fired Heaters and Steam Generators, API

Recommended Practice 556, 1st ed., American Petroleum Institute, Washington, D.C., May 1997.

5. Inspection of Pressure Vessels (Towers, Drums, Reactors, Heat Exchangers, and Condensers), API Recommended Practice 572, 2nd ed., American Petroleum Institute, Washington, D.C., February 2001.

6. Inspection of Fired Boilers and Heaters, API Recommended Practice 573, 2nd ed., American Petroleum Institute, Washington, D.C., February 2003.

7. Performance Test Code on Fired Steam Generators, ASME PTC 4-1998, American Society of Mechanical Engineers, New York, 1998.

8. Performance Test Code on Air Heaters, ASME PTC 4.3 (Reaffirmed 1991), American Society of Mechanical Engineers, New York, 1968.

9. Performance Test Code on Gas Turbine Heat Recovery Steam Generators, ASME

PTC 4.4-1981 (Reaffirmed 2003), American Society of Mechanical Engineers, New York, 1981.

10. Performance Test Code on Steam Surface Condensers, ASME PTC 12.2-1998, American Society of Mechanical Engineers, New York, 1998.

11. Performance Test Code on Atmospheric Water Cooling Equipment, ASME PTC 23-1986 (Reaffirmed 1997), American Society of Mechanical Engineers, New York, 1986.

12. "Section I: Power Boilers," 2001 ASME Boiler and Pressure Vessel Code, American Society of Mechanical Engineers, New York, 2001.

13. "Section IV: Heating Boilers," 2001 ASME Boiler and Pressure Vessel Code, American Society of Mechanical Engineers, New York, 2001.

14. "Section VI: Recommended Rules for the Care and Operation of Heating Boilers," 2001 ASME Boiler and Pressure Vessel Code, American Society of Mechanical Engineers, New York, 2001.

15. "Section VII: Recommended Guidelines for the Care of Power Boilers," 2001 ASME Boiler and Pressure Vessel Code, American Society of Mechanical Engineers, New York, 2001.

16. Power Piping, ASME B31.1-2001, American Society of Mechanical Engineers, New York, 2001.

17. Process Piping, ASME B31.3-2002, American Society of Mechanical Engineers, New York, 2002.

18. Gas Transmission and Distribution Piping Systems, ASME B31.8-2000, American Society of Mechanical Engineers, New York, 2000.

19. "Standard Classification of Coals by Rank," ASTM Designation: D 388-99, American Society of Testing and Materials, West Conshohocken, Pennsylvania, 1999.

20. "Standard Specification for Fuel Oils," ASTM Designation: D 396-02, American Society of Testing and Materials, West Conshohocken, Pennsylvania, 2002.

21. "National Fuel Gas Code, NFPA 54, National Fire Protection Association, Quincy, Massachusetts, July 19, 2002.

22. Boiler and Combustion Systems Hazards Code, NFPA 85, National Fire Protection Association, Quincy, Massachusetts, February 9, 2001. 
23. National Board Inspection Code, 2001 Edition, NB 23, The National Board of Boiler and Pressure Vessel Inspections, Columbus, Ohio, 2001.

24. Technology Characterization: Reciprocating Engines, prepared by Energy Nexus Group for the U.S. Environmental Protection Agency, Washington, D.C., February 2002.

25. Combustion Fossil Power, 4th ed., ed. J. G. Singer, Combustion Engineering, Inc., Windsor, Connecticut, 1991.

26. Steam, Its Generation and Use, 40th ed., eds. S. C. Stultz and J. B. Kitto, Babcock and Wilcox, Barberton, Ohio, 1992.

27. "Comparison of Fatigue Assessment Techniques for Heat Recovery Steam Generators,"

American Boiler Manufacturers Association, Task Group on Cyclic Service, Arlington, Virginia, 2004.

28. "Air-to-Air Energy Recovery," Chapter 44, ASHRAE Handbook—HVAC Systems and

Equipment, American Society of Heating, Refrigerating and Air-Conditioning Engineers, Inc., Atlanta, Georgia, July 6, 2000.

29. Energy Efficiency Handbook, Council of Industrial Boiler Owners, Burke, Virginia, November 1997.

30. Industrial Steam System Heat-Transfer Solutions, DOE/GO-102003-1738, U.S. Department of Energy, Washington, D.C., June 2003.

31. "Standard Specification for Liquefied Petroleum (LP) Gases," ASTM Designation: D 1835-03, American Society of Testing and Materials, West Conshohocken, Pennsylvania, 2003.

32. "Standard Practice for Use of Scrap Tire-Derived Fuel," ASTM Designation: D 6700-01, American Society of Testing and Materials, West Conshohocken, Pennsylvania, 2001.

33. C. B. Oland, Guide to Low-Emission Boiler and Combustion Equipment Selection, ORNL/TM-2002/19, Oak Ridge National Laboratory, Oak Ridge, Tennessee, April 2002.

34. Technology Characterization: Gas Turbines, prepared by Energy Nexus Group for the U.S. Environmental Protection Agency, Washington, D.C., February 2002.

35. "Wet Electrostatic Precipitation Demonstrating Promise for Fine Particulate Control," Power Engineering, PennWell Corp, Tulsa, Oklahoma, January 2001.

36. Improving Steam System Performance: A Sourcebook for Industry, DOE/GO-102002-1557, prepared by Lawrence Berkeley National Laboratory for the U.S. Department of Energy, Washington, D.C., June 2002.

37. Guideline for Gas and Oil Emission Factors for Industrial, Commercial, and Institutional (ICI) Boilers, American Boiler Manufacturers Association, Arlington, Virginia, 1997. 


\section{ELECTRIC POWER GENERATION}

Power produced by a CHP system is almost always in the form of electrical energy. The electricity may be used on site to reduce power purchases or exported to the grid for resale. Even for CHP systems that produce more power than they consume, connection to the electrical grid is generally necessary for either supplementary or emergency power. Smaller CHP systems can often be designed so power only flows in one direction from the utility to the site. Although CHP systems can be developed and operated without relying on utility power, connection of the CHP system to the electrical grid is generally preferred because it provides increased reliability and operating flexibility. The following text discusses electrical generators and inverters commonly used to produce electricity and describes issues associated with connecting the electrical grid to the site electrical distribution system.

\subsection{ELECTRICAL GENERATORS}

An electrical generator is an electromagnetic device that converts mechanical or shaft power into electrical energy. Mechanical power is generally provided by a turbine or engine that is connected to the generator shaft. A gearbox is sometimes included as part of the connection, so the generator and prime mover can rotate at a different speeds.

All electrical generators produce electromotive force or voltage differential by moving a conductor through a magnetic field. The voltage difference is proportional to the strength of the magnetic field and the speed with which the conductor moves relative to the field. Depending on the design, a generator can produce either alternating current (ac) or direct current (dc) power. In the United States, the standard frequency for ac is $60 \mathrm{Hertz}(\mathrm{Hz})$, so rotational speed of electrical generators is a multiple of 60, typically $1,200,1,800$, or 3,600 revolutions per minute (rpm). The dc power produced by an electrical generator can be converted to ac power using a device known as an inverter.

Most of the power produced by an electrical generator is used to produce real work; however, not all energy in a circuit is used productively. Some of the energy may be stored in various components such as motors and transformers within the circuit. Real power is an indication of the amount of energy that performs real work and is typically measured in units of watts or kilowatts $(\mathrm{kW})$. In simple resistive circuits, real power is defined as the product of current flowing through the circuit and the voltage across the circuit. Reactive power is a measure of the amount of energy stored in an electrical circuit that performs no real work. This energy, which may be stored in magnetic fields of transformers and motors or in electromotive fields in capacitors, is expressed in units of kilovolt-amperes-reactive (kVAR). The total power produced by an electrical generator is referred to as apparent power and is measured in units of kilovolt-amperes (kVA).

Mathematically, apparent power is the vector sum of the real and reactive power components. Power triangles such as the one shown in Fig. 5.1 are typically used to represent this relationship. The ratio between real power and apparent power is referred to as power factor. It is a measure of the efficiency with which the total power delivered by a source is used for real work. The numerical value of power factor equals the cosine of the angle between real and apparent power. So, as reactive power increases for a given amount of real power, the power factor decreases. Power factors can range from 0 to 1 and can be either inductive (lagging) or capacitive (leading), depending on whether the current that flows through a circuit lags or leads the voltage. Most industrial facilities have inductive loads such as electric induction motors with windings that act as inductors and thus typically have lagging power factors.

When the power factor for a circuit equals 1, the current and voltage are in phase and all power is being used for real work. In most other circuits where reactive loads are present, the current and voltage are out of phase as shown in Fig. 5.2, and the power factor decreases as much of the source capacity is being used for energy that is stored rather than being used for real work. Because the most useful power 


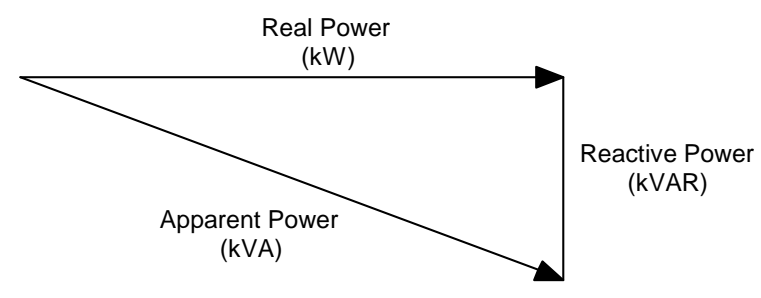

Fig. 5.1. Power triangle.

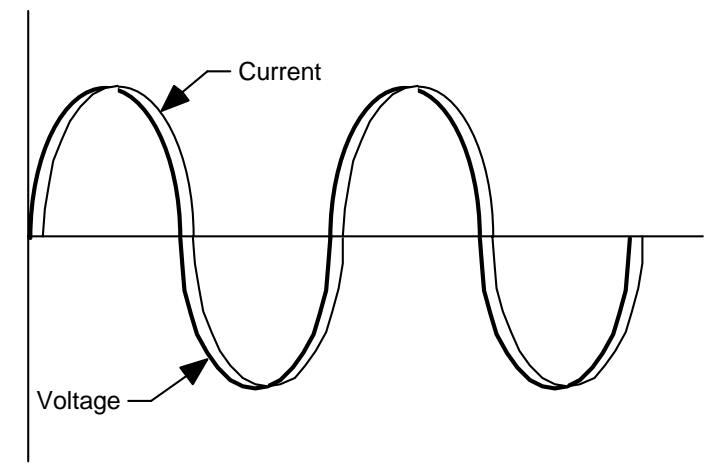

Fig. 5.2. Phase difference between current and voltage caused by reactive load.

is delivered when voltage and current are in phase, it is important to keep the power factor as close to 1 as possible. ${ }^{1}$ In addition, some utilities discourage low power factors either by requiring a minimum power factor or applying a cost penalty to consumers with low power factors. It is common to correct power factor problems caused by motors, transformers, and inductive heaters by adding capacitance to the electrical circuit. ${ }^{2}$

When a generator rating is specified by its real power output, two factors are required: (1) the total real power expressed in kilowatts, and (2) the power factor expressed as a fraction. A generator's real power output is commonly specified in kilowatts at an $80 \%$ power factor, but other power factors can also be used. Generators that produce ac power are categorized as either synchronous or induction generators, depending on the source of the reactive power that is required to create the magnetic field.

\subsubsection{Synchronous Generators}

Synchronous generators provide their own source of reactive power. Consequently, they are capable of generating electricity without relying on an external source of power such as the electrical grid. This characteristic makes synchronous generators well suited for emergency power applications and for CHP systems that need to operate even if the electrical grid is disconnected.

There are two basic types of synchronous generators. The most common type is the self-excited or brushless synchronous generator. These generators have two separate generators that perform different functions. The smaller generator produces a dc magnetic field, while the larger generator produces ac electric power. Voltage output from a self-excited generator is controlled by varying the voltage that 
produces the magnetic field. Separately excited synchronous generators use a permanent magnet rather than electricity to produce the magnetic field. ${ }^{2}$ In practice, permanent magnet synchronous generators are not used very often because permanent magnets tend to become demagnetized by working in the powerful magnetic fields inside a generator, and powerful magnets made of rare earth metals (e.g., neodynium) are relatively expensive.

When a synchronous generator is connected to the electrical grid, the frequency, voltage, and phase angle are determined by the grid. Consequently, CHP systems with synchronous generators need a mechanism for safely synchronizing to the grid. When a synchronous generator is not connected to the grid, the CHP system needs equipment for precisely controlling frequency and voltage. ${ }^{3}$ Besides producing electricity, synchronous generators can be operated in a mode that will compensate for a low site power factor.

\subsubsection{Induction Generators}

Induction generators are simply motors that are driven above their synchronous speed. In operation, an induction generator draws power from an external power source such as the electrical grid to create a magnetic field. The interaction of the magnetic fields produces a torque on the motor shaft and causes the generator to operate as a motor. Power delivered by the motor depends on the difference between the motor's rotational speed and its synchronous speed. When mechanical power flows into the motor, the speed exceeds the synchronous speed, and the motor operates as a generator. Because an induction generator requires an external power source, the magnetic field disappears, and the device no longer functions as a generator as soon as reactive power from the source is interrupted. Induction generators are generally found in smaller CHP systems because they are relatively inexpensive and their synchronization with the electrical grid only requires a minimum of protective relaying. They are used most often in package CHP systems of $300 \mathrm{~kW}$ or less. ${ }^{2}$

Although induction generators cannot operate effectively without external power, the generator inductance can interact with nearby capacitance to create an oscillating circuit whenever external power is interrupted. This interaction allows the generator to self-excite for a period of time before decaying away. While this type of operation can produce significant voltages, in general the generator does not operate at the synchronous speed, and frequency or reverse power relays are required to keep the generator from operating as a motor.

The power factor of loads served by the electrical grid will worsen when an induction generator is connected to the grid and the power from the CHP system is used on site. This condition occurs because the induction generator increases the reactive load served by the grid, and it reduces the real power drawn from the grid. Correcting this type of power factor problem often requires installing capacitors. The need for these capacitors is an issue that should be considered when assessing the technical and economic viability of cogeneration technology.

\subsection{INVERTERS}

An inverter is an electrical device that converts de power to ac power. Most inverters operate by cutting the dc power into a series of blocks or square waves at a number of different frequencies. These blocks are then electrically summed to create a voltage wave form that approximates the required ac. Voltage and frequency output from an inverter are controlled by the voltage and frequency of the electrical grid. ${ }^{3}$

Fuel cells for industrial CHP systems, which are only capable of producing dc power, normally include appropriately sized inverters for conditioning the generated power. Inverters are also used with single-shaft microturbines that operate at high speeds (more than 60,000 rpm) and generate electric power with variable frequency. This power is rectified to dc and then inverted to standard $60-\mathrm{Hz}$ ac. 


\subsection{CONTROL SYSTEMS}

Control systems are required in most CHP applications to synchronize the operation of two or more sources of power serving a common load. This may involve synchronizing two generators at a site, a generator to the electrical grid, or multiple generators to each other and the electrical grid. Electrical devices used in control systems include circuit breakers and fuses, relays, transfer switches, transformers, and microprocessors.

Circuit breakers and fuses automatically open or break an electrical circuit when specified conditions such as high current occur for a prescribed period. Relays monitor electrical conditions in a circuit including voltage, current, power, frequency, phase imbalance, and direction of power flow and signal a circuit breaker to open when prescribed conditions are not satisfied. Transfer switches are used to transfer a load from one source to another as in emergencies when the site load is transferred from the electrical grid to an emergency generator. Transformers serve vital roles in matching CHP generated voltage to the electrical grid, changing voltage configurations, providing electrical isolation between the CHP system and electrical grid, and improving power quality by reducing harmonics and voltage disturbances.

Microprocessor-based monitors and control devices are used for relaying functions; to monitor CHP system performance; and to manage operations including start-up, steady-state, shutdown, and emergency conditions. This equipment is critical to the safe and efficient operation of a CHP system. Additional information about CHP system controls is available from the American Society of Heating, Refrigerating and Air-Conditioning Engineers (ASHRAE), Inc. ${ }^{4}$

\subsection{SAFETY}

Safety is a major concern with interconnection of dispersed generators because workers performing routine maintenance or repairs to faulty transmission or distribution lines can be exposed to an electrical hazard known as "islanding."3 This phenomenon can potentially occur when a utility breaker opens and deenergizes a portion of the electrical grid that is being serviced by a CHP system. To ensure worker safety, line workers must disconnect all generation sources from the service area and establish a visibly open circuit. Before starting any repairs, they must also ground the line and test it to ensure that there is no power flowing in the line. ${ }^{1}$

Disconnecting and grounding the lines is relatively simple when the generation system is centralized and there are few sources of supply. However, with numerous sources of power supply the disconnect procedure becomes more complicated, and it is important for the utility to know what dispersed equipment is connected to the system, where that equipment is located, what transmission lines and distribution substations it uses, and where the disconnecting switches are located. To simplify this procedure, many utilities require installation of disconnect switches at specified locations in the vicinity of a CHP system.

Another potential safety issue associated with disconnecting a CHP system from the electrical grid is self-excitation of the electrical generators. When an induction generator is isolated from the rest of the grid, the absence of a grid power signal usually will shut down the generators. However, if there is sufficient capacitance in the nearby circuits to which the generator is connected (e.g., power factor correcting capacitors), the induction generator may continue to operate independently of any power supplied to the grid. The power signal produced by the isolated self-excited induction generator will not be regulated by the grid's power signal and the customer's electricity-using equipment may be damaged. More importantly, an isolated induction or synchronous cogenerator that reenergized on the customer's side of a downed transmission or distribution line, could endanger utility workers. Self-excitation is less of a problem with synchronous generators because they continue to operate independently of the grid.

There are two ways to prevent self-excitation problems. First, the utility can put the corrective 
capacitors in a central location, in which case disconnecting a cogenerator also will disconnect the capacitors and reduce the possibility of self-excitation. Alternatively, voltage and frequency relays and automatic disconnect circuit breakers can be used to protect both the customer's equipment and utility workers. ${ }^{1}$

\subsection{LIABILITY}

Although protective relays and automatic disconnect switchgear may be a required part of the CHP system installation, this equipment may not always function properly. Malfunctioning electrical devices or control systems can damage equipment or endanger the lives of utility workers. As a result of possible liability, boiler owners and operators with CHP systems may be required by a utility to carry special liability insurance to limit the responsibility of the utility or its customers. ${ }^{1}$ Often, the limits of this insurance are sufficiently high to cover a worst-case scenario of personal and property damage due to energized lines. The cost of liability insurance should be factored into any economic assessment of cogeneration viability.

\subsection{INTERCONNECTION ISSUES}

Interconnection refers to the technical, contractual, rate, and metering issues that must be settled between a CHP system owner, utility, and local permitting authorities before the system can be connected to the electrical grid. Currently, interconnection requirements vary from state to state and from utility to utility because national consensus codes and standards for CHP systems are either unavailable or only provide guidance on certain types of electrical components. Interconnection issues tend to revolve around the procedures that may be necessary to obtain interconnection, and the uncertainty about the amount and type of equipment that is necessary to protect utility line workers and the utility system in general. Key utility interconnection concerns the following: ${ }^{3}$

- Power quality-Utilities are concerned that an interconnected on-site generator not degrade the quality of power supplied by the utility as measured by voltage and frequency stability, power factor, and harmonic content. In general, with the exception of induction generators and inverters, the quality of power available from an on-site generator will exceed the quality of power that is available from the grid.

- Power safety-Utilities are concerned that an interconnected generator has the potential to energize a utility circuit that is not being powered by the utility. This condition can result in a safety hazard to utility personnel working on that circuit. Most utilities will require installation of an external disconnect switch that is accessible by utility personnel and that can be used to disconnect and lock out the CHP system.

- Grid operations-Utility operation of the grid can be quite complex, including the coordination of relays, switches, and fault controls. The interconnection of a CHP system or any other active source of power within the electrical grid should be reviewed to avoid jeopardizing the utility's ability to manage grid operations. For example, most new forms of on-site power generation use protective relaying functions that are programmed into the control system. This can create a problem for utilities because most have guidelines requiring that these functions be tested on a periodic basis to prove that they will function properly in the event of a system disturbance. Because manufacturers do not routinely design their units to allow for testing of protective relaying functions, utilities seldom allow these types of on-site power generating system to connect to the grid without additional testing or supplementary relaying. This installation requirement adds to the overall cost of the CHP system.

- Dispatchability-Utilities require the right to request that a CHP system be isolated from the electrical grid during periods of emergency or for grid safety. This dispatchability is technical and 
distinctly different from a utility's request or contractual requirement that a CHP system cease power deliveries due to operating economies.

Standardized requirements for inverters, converters, charge controllers, and output controllers have been adopted by Underwriters Laboratories, Inc. (UL) and are provided in UL 1741.5 Equipment covered by this standard is used in stand-alone (not grid connected) or utility-interactive (grid-connected) power systems. The utility-interactive inverters and converters discussed in the standard are intended to be installed in parallel with an electric supply system or an electric utility to supply common loads.

Interconnection guidelines for distributed generating systems in Texas were adopted on February 4, 1999, by the Public Utility of Texas. ${ }^{6}$ The purpose for these guidelines is to provide a starting point for negotiations between the owner or operator of the generating units and an electric utility representative. Information in these guidelines may be helpful to boiler owners and operators in other states when considering safety standards, system stability requirements, protection requirements, switchgear requirements, metering requirements, generation control, testing and record keeping, insurance, and other related issues.

In March 1999, the Institute of Electrical and Electronics Engineers (IEEE) Standards Association Board voted to undertake the development of uniform standards for interconnecting distributed resources with electric power systems. Since then, the IEEE Standards Coordinating Committee 21 has completed work on the development of the IEEE 1547 Standard for Distributed Resources Interconnected with Electric Power Systems. ${ }^{7}$ This consensus standard contains specific requirements related to performance, operation, testing, safety, and maintenance of interconnections between distributed resources and other electric power systems. ${ }^{8}$

\subsection{REFERENCES}

1. Industrial and Commercial Cogeneration, Office of Technology Assessment, Congressional Board of the 98th Congress, Washington, D.C., February 1983.

2. J. A. Orlando, Cogeneration Planner's Handbook, The Fairmont Press, Inc., Lilburn, Georgia, 1991.

3. J. A. Orlando, Cogeneration Design Guide, American Society of Heating, Refrigerating and AirConditioning Engineers, Inc., Atlanta, Georgia, 1996.

4. "Cogeneration Systems and Engine and Turbine Drives," Chapter 7, ASHRAE Handbook-HVAC Systems and Equipment, American Society of Heating, Refrigerating and Air-Conditioning Engineers, Inc., Atlanta, Georgia, July 6, 2000.

5. Inverters, Converters, and Controllers for Use in Independent Power Systems, UL 1741, Underwriters Laboratories, Inc., Northbrook, Illinois, January 17, 2001.

6. 1999 Interconnection Guidelines for Distributed Generation in Texas, Public Utility Commission of Texas, February 4, 1999. http://www.puc.state.tx.us/electric/projects/20363/guidlns.cfm

7. Standard for Interconnecting Distributed Resources with Electric Power Systems, IEEE Standard No. 1547-2003, Institute of Electrical and Electronics Engineers, New York, 2003.

8. T. S. Basso and R. DeBlasio, "IEEE P1547 Series of Standards for Interconnection," NREL/CP-560-34003, National Renewable Energy Laboratory, Golden, Colorado, May 2003. 


\section{COOLING EQUIPMENT AND ROTATING MACHINERY}

Most CHP systems use mechanical energy to generate electricity and thermal energy to satisfy process heating requirements, but these two types of energy can be used for other purposes. For example, thermal energy can be used by absorption chillers and desiccant dehumidifiers to produce a cooling rather than a heating effect, and mechanical energy can be used to drive fans, pumps, and compressors rather than generate electricity. ${ }^{1,2}$ Use of cooling equipment and rotating machinery in CHP applications provides an alternative to conventional electric motor drive systems and offers flexibility in meeting operational requirements.

\subsection{ABSORPTION CHILLERS}

Absorption chillers are cooling machines that use heat as the primary source of energy for driving an absorption refrigeration cycle. They are classified as indirect-fired, heat-recovery, or direct-fired units. Indirect-fired absorption chillers use steam or hot water to produce a cooling effect. Heat-recovery absorption chillers represent another type of indirect-fired absorption chiller. These units use hot exhaust gases rather than steam or hot water as a heat source. Direct-fired absorption chillers have burners that combust fossil fuels to generate the heat needed to produce a cooling effect. Indirect-fired absorption chillers that use steam or hot water are well suited for CHP applications that also require cooling. Lowpressure, steam-driven absorption chillers are available in capacities ranging from 100 to 1,500 tons (Ref. 1).

Single-stage absorption chillers can operate on hot water as low as $240^{\circ} \mathrm{F}$ or low-pressure steam in the range of 12 to $15 \mathrm{psig}$. The required steam flow rate varies from about 10 to $20 \mathrm{lb} / \mathrm{ton} \bullet \mathrm{h}$. A typical single-stage absorption cycle uses water as the refrigerant and lithium bromide ( $\mathrm{LiBr}$ ) as the absorbent. Although these units are suitable for many chilled water applications, they cannot operate below $32^{\circ} \mathrm{F}$ because the water freezes. When lower temperatures are required, ammonia can be used as the refrigerant and water as the absorbent. More efficient two-stage absorption chillers require steam at pressures of approximately $115 \mathrm{psig}$, but they can also use heat in reciprocating engine exhaust gases as an energy source. Chillers operating on $\mathrm{LiBr}$ require cooling towers while ammonia-water chillers can be air or water cooled. Additional information about absorption chillers is provided in the ASHRAE handbook ${ }^{3}$ and other reference sources. ${ }^{4,5}$

Compared to single-stage absorption chillers, the capital cost of multiple-stage absorption chillers is higher, but they are more energy efficient and thus less expensive to operate. The required steam flow rate is about $10 \mathrm{lb} /$ ton॰h. Overall economic attractiveness of an absorption chiller depends on many factors, including the cost of capital and the cost of energy. If the addition of an absorption chiller is being considered, it is important to perform an economic analysis of the absorption chiller compared to chillers that operate on other power sources. This analysis is necessary to establish the proper value for the recovered heat. ${ }^{6}$

\subsection{DESICCANT DEHUMIDIFIERS}

Solids and liquids that are capable of attracting and holding moisture are known as desiccants. Some common desiccants include silica gel, activated alumina, alumina oxide, and deliquescent absorbents such as lithium chloride $(\mathrm{LiCl})$ and calcium chloride $\left(\mathrm{CaCl}_{2}\right)$. Although removing moisture from air using a desiccant slightly increases the air temperature, less energy is required by a chiller to cool the dehumidified air. Humidity control is another important aspect of space conditioning for comfort cooling. Maintaining the humidity of a conditioned space below $60 \%$ relative humidity minimizes the growth of mold, bacteria, and other harmful microorganisms. 
Desiccant dehumidifiers use heat to achieve a cooling effect by removing water vapor from an air stream and thereby decrease the latent cooling load. When desiccants become saturated, they lose their ability to remove moisture and must be either replaced or recharged. Recharging a desiccant involves increasing its temperature to expel the captured moisture. The recharged desiccant is then capable of attracting and holding additional moisture. ${ }^{7}$ Heat recovered from CHP systems is suitable for recharging most desiccants.

There are five basic types of desiccant dehumidification equipment. ${ }^{5}$

1. Liquid spray towers use a lithium chloride solution to continuously remove moisture from a process air stream. In these tower systems, air is both cooled and dehumidified as it contacts the desiccant spray.

2. Solid towers remove moisture by passing air over a column of solid packed desiccant such as silica gel. When the desiccant becomes saturated with moisture, air flow is diverted to a second tower, so the first tower can be regenerated.

3. Rotary dehumidifiers simultaneously remove moisture from one air steam while regenerating the desiccant with another. A seal between the process air and the regenerative air streams prevents the two from mixing. Rotating wheel systems are becoming increasingly more common as they serve all conditions down to $-60^{\circ} \mathrm{F}$ dew point.

4. Multiple vertical bed systems are somewhat of a hybrid between solid tower and rotating bed systems. They use a circular carousel with many granular desiccant vertical beds that rotate between the process and regenerative air streams.

5. Desiccant wheels function like a rotating bed that uses a wheel of packed granular desiccant. ${ }^{8}$

In practice, desiccant dehumidifiers are designed to operate either independently of the chiller or in series with the chiller. For CHP systems, it is often desirable to reduce moisture from the air using a desiccant dehumidifier and then cool the dehumidified air using conventional cooling equipment. Alternatively, a desiccant dehumidifier can be used to further dehumidify and partially reheat cool, saturated air that leaves a conventional cooling coil. By positioning the desiccant dehumidifier after the cooling coil, dehumidification performance of the desiccant is enhanced. This operating mode is well suited for use with CHP systems because it requires moderate or lower temperatures for regenerating the desiccant.

\subsection{ROTATING MACHINERY}

Rotating machinery used in industrial applications is normally powered by electric motors, but the mechanical energy needed to power this machinery can also be provided by RICEs and steam and gas turbines that are part of CHP systems. ${ }^{9}$ Rotating machinery that can be powered by these prime movers includes

- air compressors,

- pumps (centrifugal and positive-displacement including reciprocating and rotary),

- fans (axial-flow and radial or centrifugal), and

- refrigeration compressors (rotary, scroll, reciprocating, screw, and centrifugal). 


\subsubsection{Air Compressors}

Compressed air is used in many industrial processes to operate tools, power equipment, and provide process control. Because the annual operating cost of a compressed air system can account for a significant portion of a facility's operating energy budget, proper use of compressor technology is very important. Air compressors commonly used in industry include

- reciprocating (single-stage or multistage),

- rotary (rotary screw, sliding vane, or rotary lobe),

- centrifugal (single-stage or multistage), and

- axial-flow. $^{5}$

Mechanical energy needed to power air compressors is generally supplied by electric motors, but it can also be supplied by steam turbines, gas turbines, or RICEs. Steam turbines are often used to power large screw or centrifugal air compressors, while back-pressure steam turbines have the potential for driving air compressors at extremely low operating costs. Gas turbines can be used effectively to power very large centrifugal and radial compressors, especially in CHP systems that have large, constant highpressure steam requirements. Reciprocating internal combustion engines have been powering screw compressors for many years. They are generally packaged with reciprocating compressors and are not as commonly used with centrifugal compressors.

\subsubsection{Pumps}

Pumps are essential to almost every industrial process application that requires fluid flow against resistance. Although there are many different pumps, they are classifieds as either positive-displacement or centrifugal types. Besides electric motors, steam turbines can be used to drive most types of pumps. Use of gas turbines and RICEs as prime movers for pumping systems is limited primarily to remote field applications such as irrigation and pipeline pumping service.

\subsubsection{Fans}

Fans are designed to move air or other gases and are similar in many respects to pumps and air compressors. They are classified as either axial-flow, radial-flow, mixed-flow, or resistance. ${ }^{5}$ Electric motors are the predominate drivers for fans. However, back-pressure steam turbines can be used for a variety of industrial fan applications, including drives for large capacity boiler fans. Because boiler fans are essential for boiler operation, it is not uncommon for these fans to be powered by a hybrid system consisting of a steam turbine and an electric motor as shown in Fig. 6.1. These hybrid fans are needed during startup operations when no steam is available. In some cases, RICEs can be used to power fans for industrial processes, but they are used primarily in remote locations or when a nonelectric power source is needed. Fans powered by gas turbines are not very common.

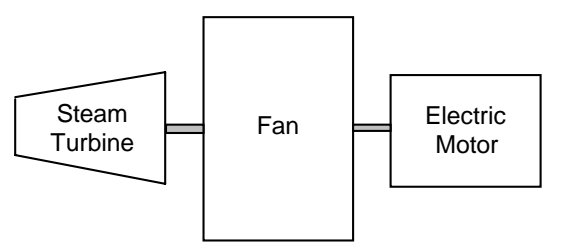

Fig. 6.1. Hybrid fan system. 


\subsubsection{Refrigeration Compressors}

Refrigeration systems remove heat from a source and thereby produce a cooling effect. The mechanical chillers in these systems operate on the vapor-compression cycle and use either a reciprocating, centrifugal, or screw-type compressor to compress the working fluid to produce the required high-pressure vapor. These compressors are rotating devices that are generally driven by electric motors, reciprocating engines, or steam turbines. Although reciprocating engines are effective power sources for mechanical chillers, they are typically not used for this purpose in CHP applications. However, reciprocating engines can be coupled to an electrical generator and a mechanical chiller in a dual-service arrangement as shown in Fig. 6.2. In this configuration, the reciprocating engine produces a cooling effect during normal operation and electricity during an emergency. Dual-service arrangements have lower capital investment than two separate engines in single service, and they are more reliable in an emergency because they operate continuously or on a regular basis. Mechanical chillers powered by gas turbines are not very common.

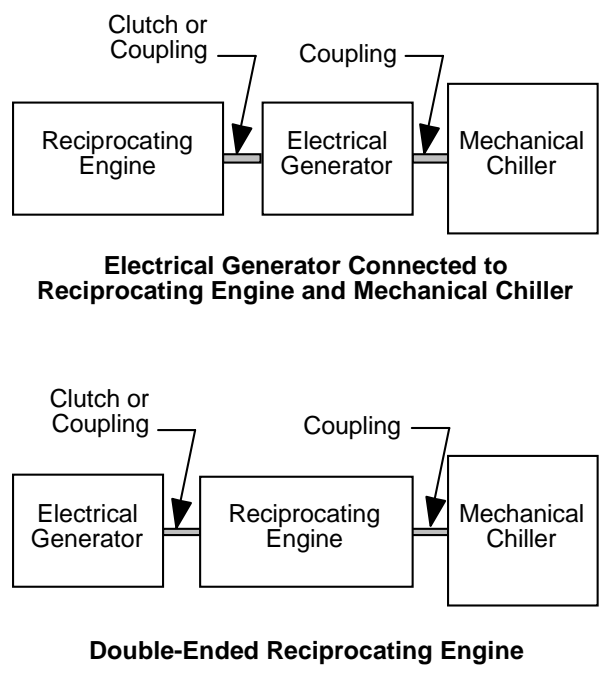

Fig. 6.2. Dual-service reciprocating engine applications.

\subsection{REFERENCES}

1. "Use Low-Grade Waste Steam to Power Absorption Chillers," DOE/GO-102001-1277, Steam Tip Sheet 14, U.S. Department of Energy, Washington, D.C., May 2001.

2. "Consider Steam Turbine Drives for Rotating Equipment," DOE/GO-102002-1475, Steam Tip Sheet 21, U.S. Department of Energy, Washington, D.C., January 2002.

3. "Absorption Cooling, Heating, and Refrigeration Equipment," Chapter 41, ASHRAE HandbookRefrigeration, American Society of Heating, Refrigerating and Air-Conditioning Engineers, Inc., Atlanta, Georgia, 1998.

4. J. A. Orlando, Cogeneration Planner's Handbook, The Fairmont Press, Inc., Lilburn, Georgia, 1991.

5. N. Petchers, Combined Heating, Cooling and Power Handbook: Technologies and Applications, The Fairmont Press, Inc., Lilburn, Georgia, 2003.

6. J. A. Orlando, Cogeneration Design Guide, American Society of Heating, Refrigerating and AirConditioning Engineers, Inc., Atlanta, Georgia, 1996. 
7. "Desiccant Dehumidification and Pressure Drying Equipment," Chapter 22, ASHRAE Handbook-HVAC Systems and Equipment, American Society of Heating, Refrigerating and AirConditioning Engineers, Inc., Atlanta, Georgia, July 6, 2000.

8. Energy Efficiency Handbook, Council of Industrial Boiler Owners, Burke, Virginia, November 1997. 


\section{COMBINED HEAT AND POWER SYSTEMS}

Integrating cogeneration technology into new or existing ICI boiler installations can be challenging because CHP systems are unlimited in their thermodynamic possibilities, and thus in the configuration and sizing of the various components. In addition, the design, arrangement, and cost of components are often influenced by process temperature requirements, pressure limits, and electric power needs. Implementing cogeneration technology is a matter of cycle selection and design of piping and valving arrangements, and not of basic differences in boilers, turbines, heat exchangers, and electrical generators. ${ }^{1}$

Achieving optimum energy efficiency involves maximizing the work output for a given amount of fuel and minimizing heat rejection from the system. This is accomplished by selectively arranging a series of thermodynamic processes into a cycle where heat is continuously converted to work. ${ }^{2}$ For cogeneration projects, heat-recovery schemes are classified as either topping-cycle or bottoming-cycle systems 3 depending on the sequence the fuel energy is used. Descriptions of a CHP system based on these cycles are presented in the following sections. Also included are systems known as combined-cycle systems that integrate both topping- and bottoming-cycle thermodynamic processes into the same systems. Details about prime movers and other components used in topping- and bottoming-cycle systems are discussed in Chaps. 3-6. Comparisons of typical size and output characteristics for various CHP systems are presented in Table 7.1.

Uniform test methods and procedures for determining the thermal performance and electrical output of heat-cycle electric power plants and cogeneration facilities have been issued by the American Society of Mechanical Engineers in the Performance Test Code on Overall Plant Performance, ASME PTC 46 (Ref. 4). This standard provides explicit procedures for the determination of corrected net power, heat rate, and heat input for topping-cycle and combined-cycle plants under normal operating conditions. Important uses for the test results include comparing actual performance to design values and monitoring time-dependent changes in overall plant performance.

\subsection{TOPPING-CYCLE SYSTEMS}

In topping-cycle CHP systems, energy is first used to generate electricity. The rejected heat is then used for process heating applications. Thermal energy exhausted from the electricity generating equipment is captured and used for a variety of useful purposes, such as manufacturing, space heating and cooling, water heating, and drying. Topping-cycle CHP systems are more common than bottoming-cycle systems, which are discussed in Sect. 7.2.

The three prime movers most often used in topping-cycle CHP systems include steam turbines, gas turbines, and reciprocating engines. Fuel cells and microturbines can also be used to generate electricity, but these technologies are not as well suited for industrial boiler applications.

\subsubsection{Steam Turbine Topping Systems}

Much of the electricity produced in the United States is generated by steam turbines in conventional fossil-fuel-fired power plants arranged in the configuration shown in Fig. 7.1. In these plants, highpressure steam produced in either a power boiler or a HRSG expands through a turbine that drives an electrical generator. For typical coal-fired power plants, less than $40 \%$ of the energy in the fuel is converted to electricity. Although steps are taken to reduce energy losses, thermal energy remaining after electricity is generated is discharged to the surrounding air or water as waste heat in order to satisfy thermodynamic requirements. Because conventional power plants only use fuel energy to produce electricity, they are not classified as cogeneration facilities. 


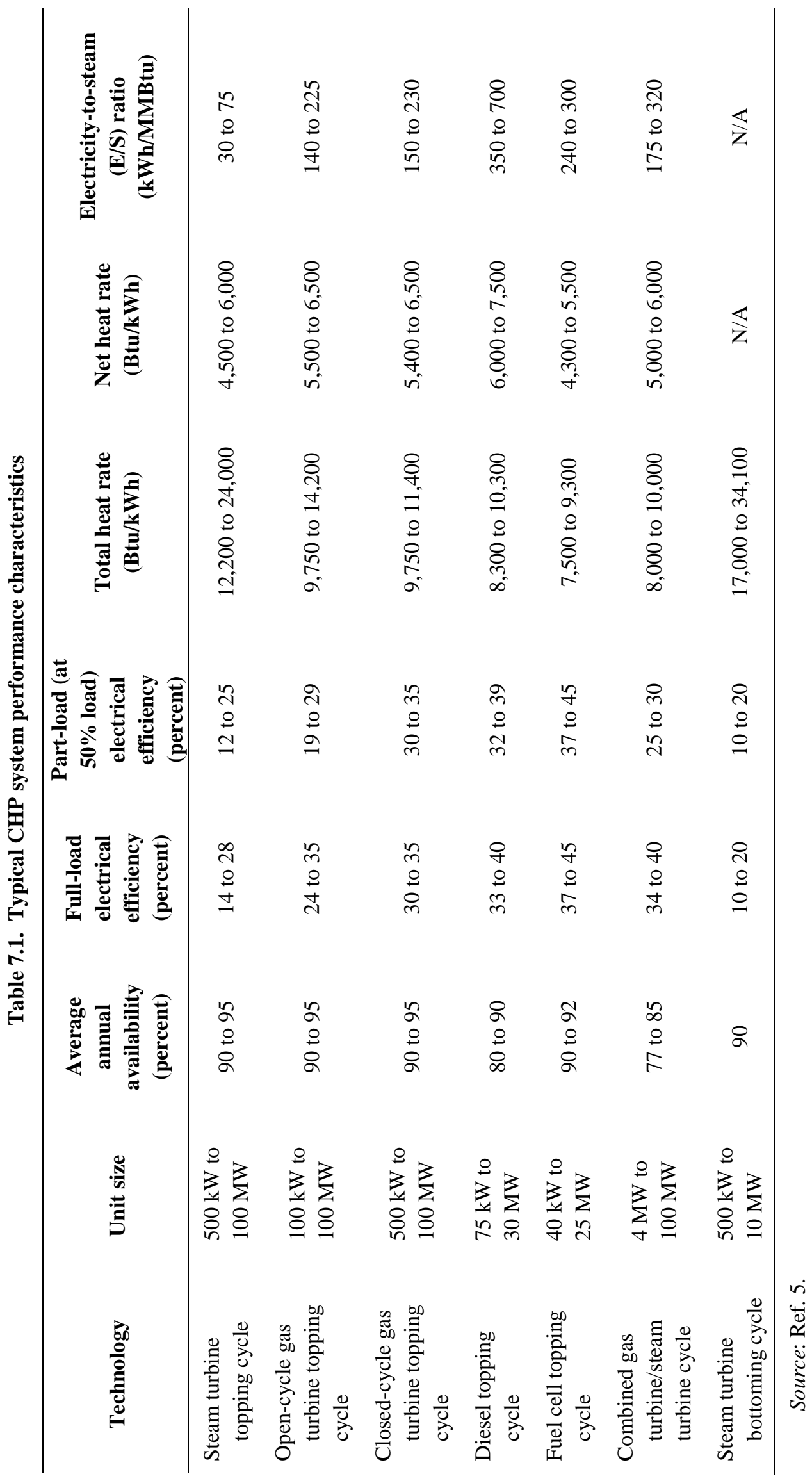




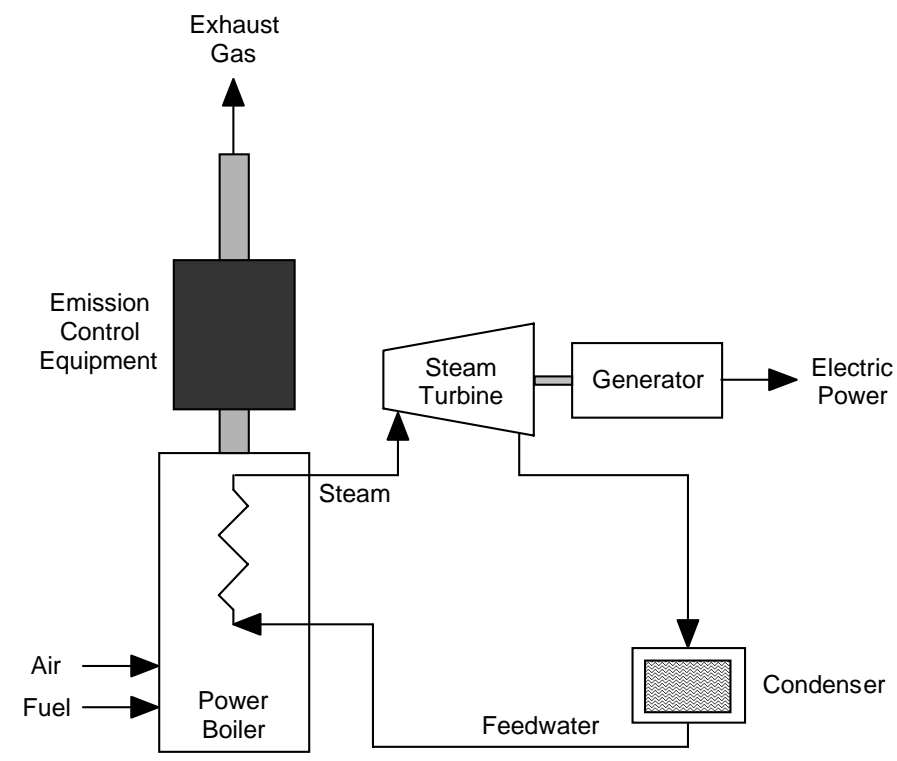

Fig. 7.1. Configuration of a steam turbine toppingcycle system used in a conventional power plant for electric power production.

The primary difference between a conventional power plant and a steam turbine topping-cycle CHP system is the manner in which waste heat is handled. Rather than discharging residual heat to the environment, steam turbine CHP systems use the thermal energy that leaves the steam turbine for useful process applications. By producing both electricity and thermal energy, these systems use more of the energy available in the fuel than conventional power plants. Depending on the relative amount of electricity that is generated, steam turbine CHP systems are generally able to use between $65 \%$ and $85 \%$ of the energy in the fuel..$^{5}$

Components used in steam turbine CHP systems are typically arranged in the configuration shown in Fig. 7.2. These components can be successfully integrated into almost any new or existing boiler installation provided the boiler produces a sufficient quantity of steam at the required pressure and temperature. Although project success does not depend on the design of the boiler or the type of fuel it burns, overall fuel consumption will increase as more fuel is needed to produce steam for both electric power generation and process heating applications. From an environmental permitting viewpoint, it is important to recognize that increased fuel consumption results in increased emissions at the CHP site.

Overall efficiency of steam turbine CHP systems is generally not affected by turbine inlet temperatures or part-load operation when less than the maximum possible amount of electricity is being generated. However, electric power generating efficiency increases with increasing inlet temperature and pressure ratio and with size up to about $30 \mathrm{MW}$. The cost of installing steam turbine CHP systems depends on factors such as the size of the system, the kind of fuel that is fired, and the type of boiler selected. Economies of scale are evident for steam turbine CHP systems larger than about $10 \mathrm{MW}$ (Ref. 5).

Steam turbines used in topping-cycle CHP systems are usually either back-pressure systems or extraction-condensing systems as shown in Figs. 7.3 and 7.4, respectively. Extracting-condensing turbines have higher electrical efficiencies than back-pressure turbines but are more complex to design. ${ }^{6}$ Heat extracted from the steam in extraction-condensing systems is optimized by exhausting the steam from the turbine at less than atmospheric pressures. Back-pressure (noncondensing) turbines exhaust steam at or above atmospheric pressure. In these systems, all condensation occurs downstream from the 


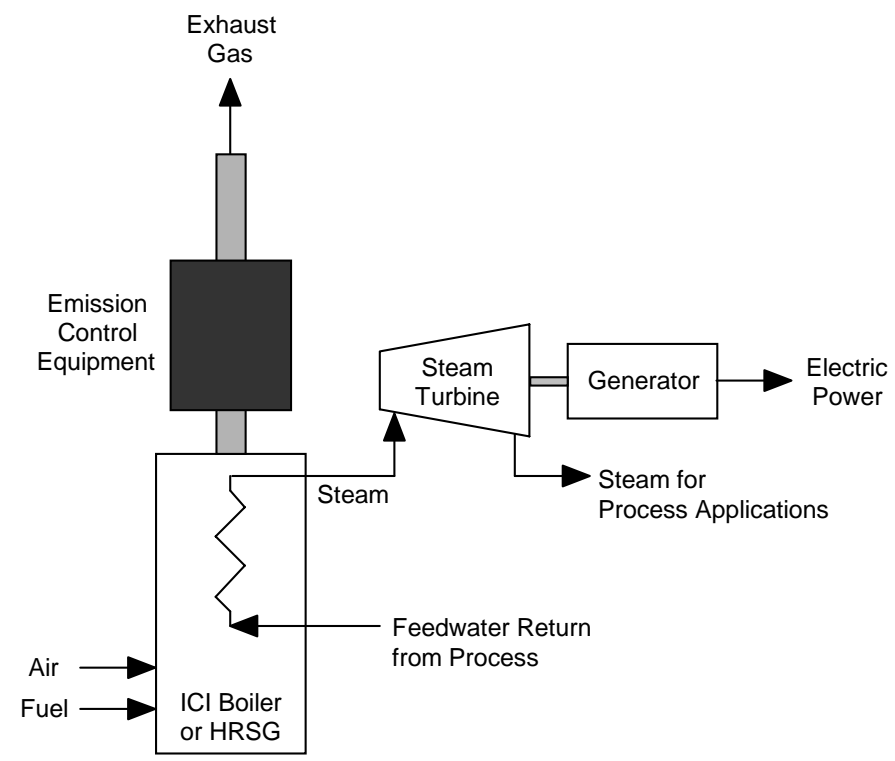

Fig. 7.2. General configuration of a steam turbine topping-cycle CHP system.

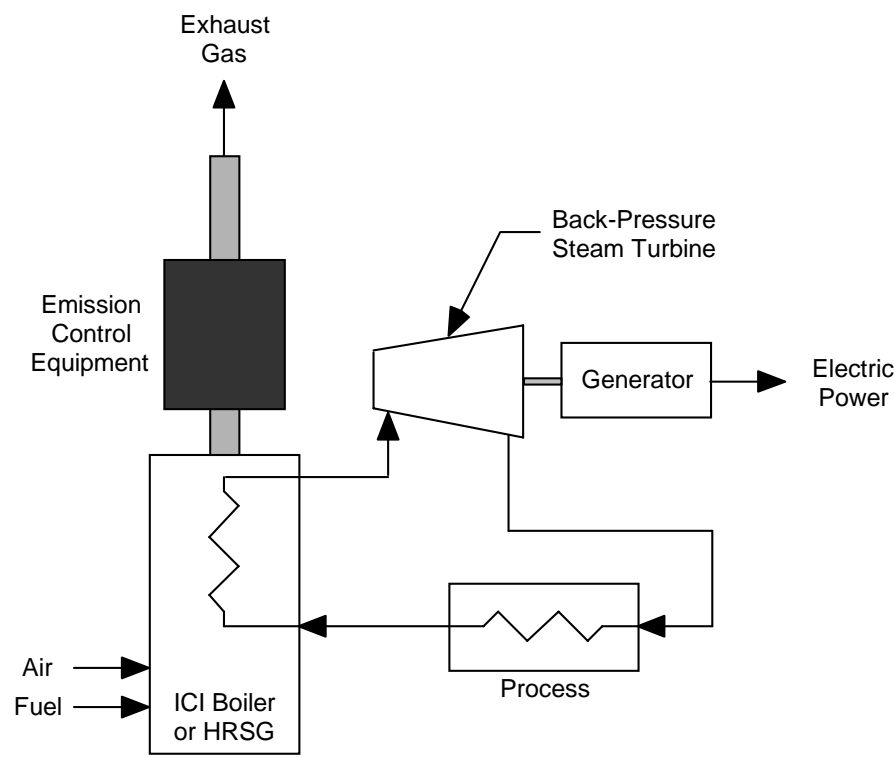

Fig. 7.3. Configuration of a back-pressure steam turbine topping-cycle CHP system for ICI boiler applications. 


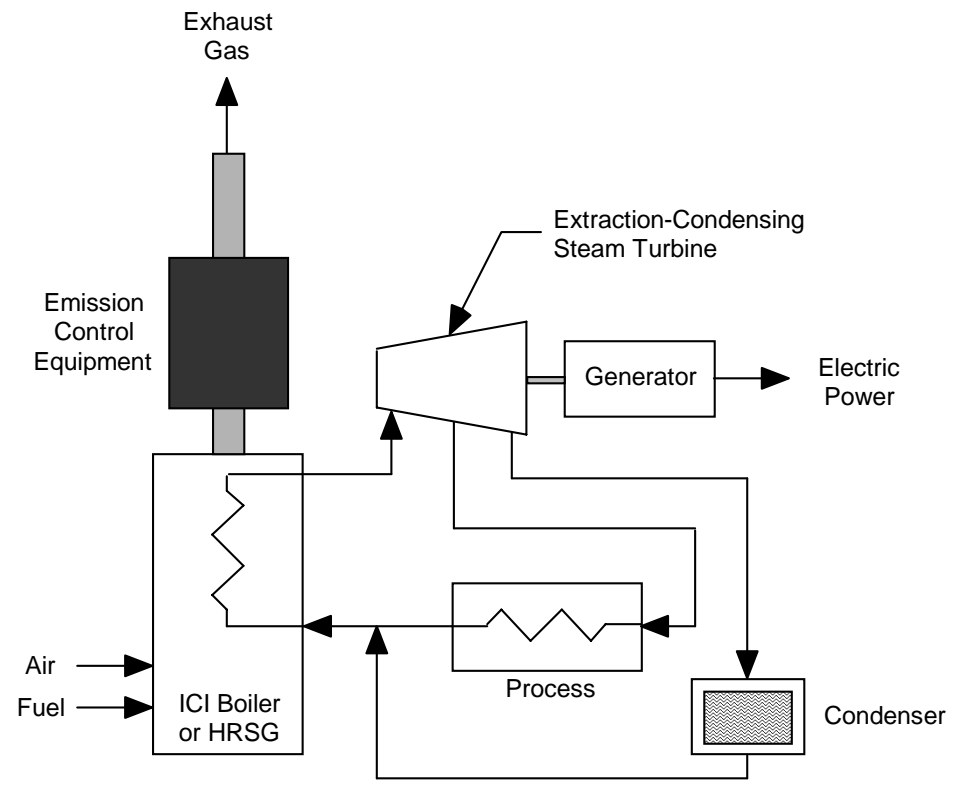

\section{Fig. 7.4. Configuration of an extraction-condensing steam turbine topping-cycle CHP system for ICI boiler applications.}

turbine in the process. ${ }^{7}$ Used in this way, back-pressure steam turbines can function as substitutes for pressure-reducing valves. In this application, back-pressure steam turbines provide pressure regulation and generate useful power. These systems have the best marginal heat rate for electric generation. The complexity of individual CHP projects dictates the type of steam turbine to employ to achieve optimal performance. ${ }^{6}$ Discussions about the types of steam turbines that are available are presented in Sect. 4.1.

Steam turbines also have relatively low ratios of electric-to-thermal power production because they have relatively low upper-temperature limits. It is this temperature limit that, in combination with the desired steam temperature, determines the amount of electricity that can be generated. Of the $85 \%$ useful energy obtainable in steam turbine CHP systems, typically $14 \%$ is used for electric power production, and $71 \%$ is used for process heat. However, the power-to-heat ratio will vary according to the amount of high-pressure steam that is directed from the boiler to process heating applications. Thus, an increase in process steam temperature corresponds to a decline in electric power production and an increase in heat production. Overall fuel utilization (power plus heat) remains relatively constant at a variety of process temperatures. All that changes is the proportion of total fuel use devoted to electric power generation and process heat. ${ }^{5}$

\subsubsection{Gas Turbine Topping Systems}

Gas turbine topping-cycle CHP systems are used throughout the world as an effective way to simultaneously produce power and heat from a single fuel source. Ranging in size from $500 \mathrm{~kW}$ to hundreds of megawatts, gas turbines (also referred to as combustion turbines) turn generators to produce electricity while providing useful thermal energy. ${ }^{6}$ Although natural gas is commonly fired in these systems, some gas turbines can burn fuel oil and other gaseous fuels. Solid fuels such as coal, municipal waste, and biomass can also be gasified to produce gaseous fuel suitable for gas turbines. Depending on their design, gas turbine topping-cycle CHP systems operate in either open-cycle or closed-cycle configurations with or without regeneration. ${ }^{5}$ 


\subsubsection{Open-cycle gas turbine topping systems}

Components for open-cycle gas turbine CHP systems are arranged into either simple or regenerative configurations. In simple open-cycle systems, exhaust gases from the gas turbine combustion chamber are supplied directly to the boiler or HRSG as shown in Fig. 7.5. As an alternative, heat available in the exhaust gases is recovered and used to preheat the feedwater or to produce steam for process applications. Regenerative open-cycle gas turbine CHP systems are arranged somewhat differently. They include a heat exchanger known as a recuperator that transfers heat from the exhaust gas stream to the incoming compressed air as shown in Fig. 7.6. Regenerators increase the mechanical efficiency of the cycle by reducing the amount of fuel required to produce a specified turbine inlet temperature, but they also reduce the temperature of the exhaust and thereby decrease the amount of heat that is available for process applications. Although regenerative open-cycle gas turbine CHP systems are technically feasible, the design of an effective and reliable regenerator can be challenging. Material selection, heat transfer, thermal stresses, and constructability are key issues that must be considered in designing a regenerator that can recover waste heat from the exhaust gas stream while being exposed to the high-temperature exhaust gases that are typically around $1,200^{\circ} \mathrm{F}$.

Most open-cycle gas turbine CHP systems burn relatively clean fuels like natural gas or No. 2 fuel oil to reduce turbine problems resulting from exposure to high-temperature exhaust gases and combustion products. High-temperature exhaust gas that contains impurities (e.g., sodium, potassium, calcium, vanadium, iron, sulfur, and particulates) can corrode some metals used in turbine construction, and certain residual solids in the exhaust gas can erode the turbine blades. Other types of fuel such as residual oil or liquid or gaseous fuels derived from coal or biomass typically cannot be fired in open-cycle gas turbines without an auxiliary fuel cleaning system.

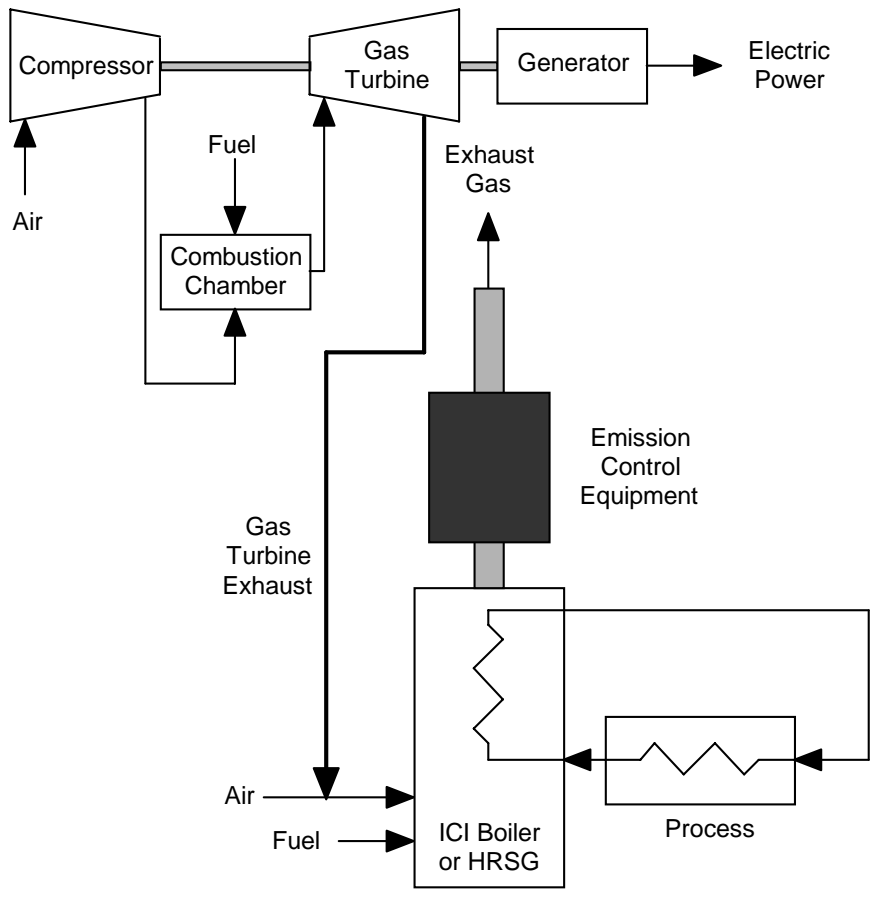

Fig. 7.5. Configuration of an open-cycle gas turbine topping-cycle CHP system (without recuperator) for ICI boiler applications. 


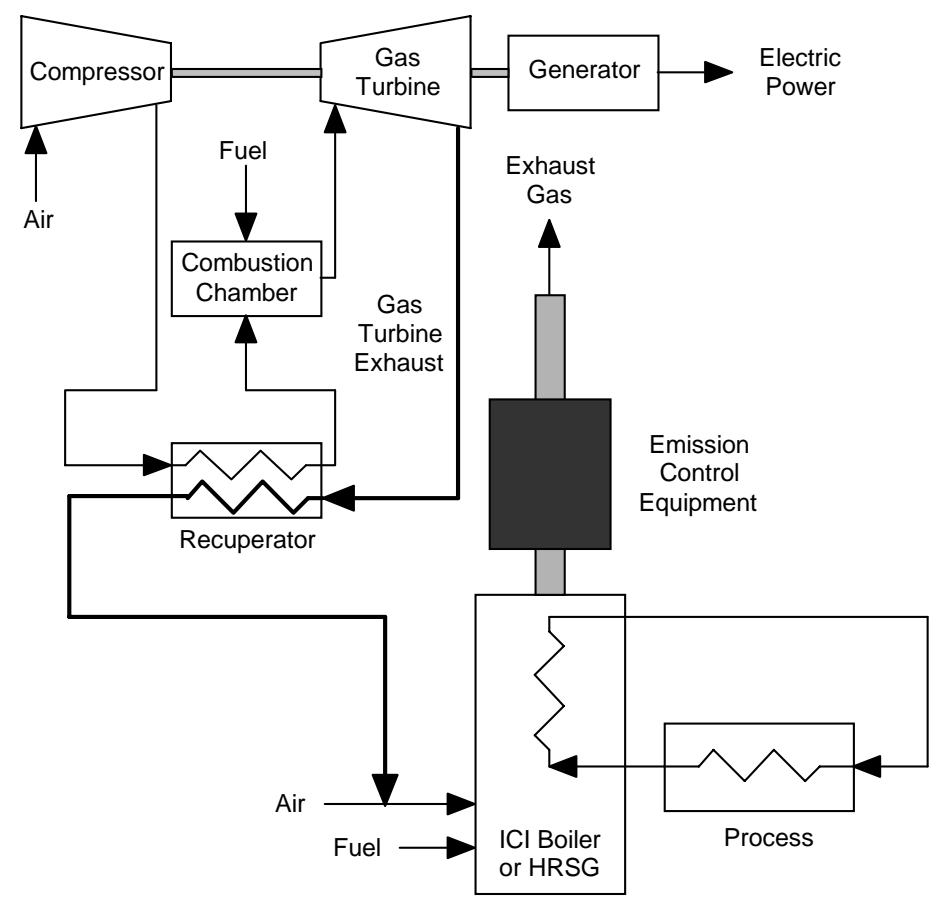

Fig. 7.6. Configuration of an open-cycle gas turbine topping-cycle CHP system (with recuperator) for ICI boiler applications.

Heat-recovery units for open-cycle gas turbine systems serve two functions. They recover waste heat from the gas turbine exhaust and provide additional heat needed to meet process demands. Although boilers and supplementary fired HRSGs of almost any design that burn liquid or gaseous fuel can be used in open-cycle gas turbine CHP systems, units that are supplied with a mixture of combustion air and gas turbine exhaust must be capable of handling the high-temperature combustion products exhausted from the gas turbine. Depending on the composition of the fuel burned in the gas turbine, the exhaust may contain oxygen, $\mathrm{NO}_{\mathrm{x}}, \mathrm{CO}_{2}$, and $\mathrm{CO}$ as well as unburned hydrocarbons and VOCs. Because the exhaust contains $15 \%$ or more oxygen, it will support additional combustion. ${ }^{7}$ Due to potential combustion control and operating problems, effects of these gases on performance and emissions need to be assessed on a case-by-case basis.

Open-cycle gas turbine CHP systems tend to have slightly lower overall fuel efficiency than steam turbine CHP systems, but the most efficient gas turbines can have a higher overall efficiency than the least efficient steam turbines. On the other hand, open-cycle gas turbines have much higher E/S ratios than steam turbines, and a higher electric generating efficiency at both full- and part-load operation. Unlike steam turbines, the electric efficiency for gas turbines is reduced significantly by part-load operation. Moreover, the efficiency of open-cycle gas turbines varies with the addition of a regenerator, because regenerative cycles produce additional electricity at the expense of recoverable thermal energy and overall efficiency. Therefore, for cogeneration applications, overall fuel efficiency is higher with simple open-cycle gas turbines, but electric generating efficiency (both full- and part-load) is higher with regenerative open cycles. As with steam turbines, the efficiency of open-cycle gas turbines tends to increase with size up to about $30 \mathrm{MW}$, and remains relatively constant in larger systems. ${ }^{5}$ Open-cycle gas turbines are generally used in CHP systems with generation capacities less than 25 MW (Ref. 6). 


\subsubsection{Closed-cycle gas turbine topping systems}

Like open-cycle systems, components for closed-cycle gas turbine CHP systems can also be arranged into either simple or regenerative configurations. The primary difference between the two systems is the working fluid that expands through the gas turbine. In open-cycle systems, the working fluid is the exhaust gas from the combustion chamber, but in closed-cycle systems, the working fluid is another gas such as air or helium that circulates through a closed circuit. The working fluid receives its heat from a heat exchanger that uses heat from the exhaust gas to increase the working fluid to the required inlet temperature. This arrangement ensures that both the working fluid and the turbine machinery are isolated from the high-temperature exhaust gas and the products of combustion. By eliminating erosion and corrosion problems in the turbine, closed-cycle systems permit greater fuel flexibility. Properly designed closed-cycle systems can burn coal, industrial or municipal wastes, biomass, and almost any types of liquid and gaseous fuels, including natural gas and fuel oil. The arrangement of a closed-cycle gas turbine CHP system in which the working fluid is supplied directly to the boiler is shown in Fig. 7.7. When a regenerator is added to the system to preheat combustion air, a slightly different configuration such as the one shown in Fig. 7.8 is required.

Although any gas can serve as the working fluid in closed-cycle gas turbine CHP systems, air has the advantage of reducing sealing requirements and mechanical complications. Heavy molecular weight gases (such as argon) reduce the size of the turbine machinery but increase that of the heat transfer components. Lighter molecular weight gases (such as helium) require more extensive turbine machinery but minimize the size of heat transfer equipment.

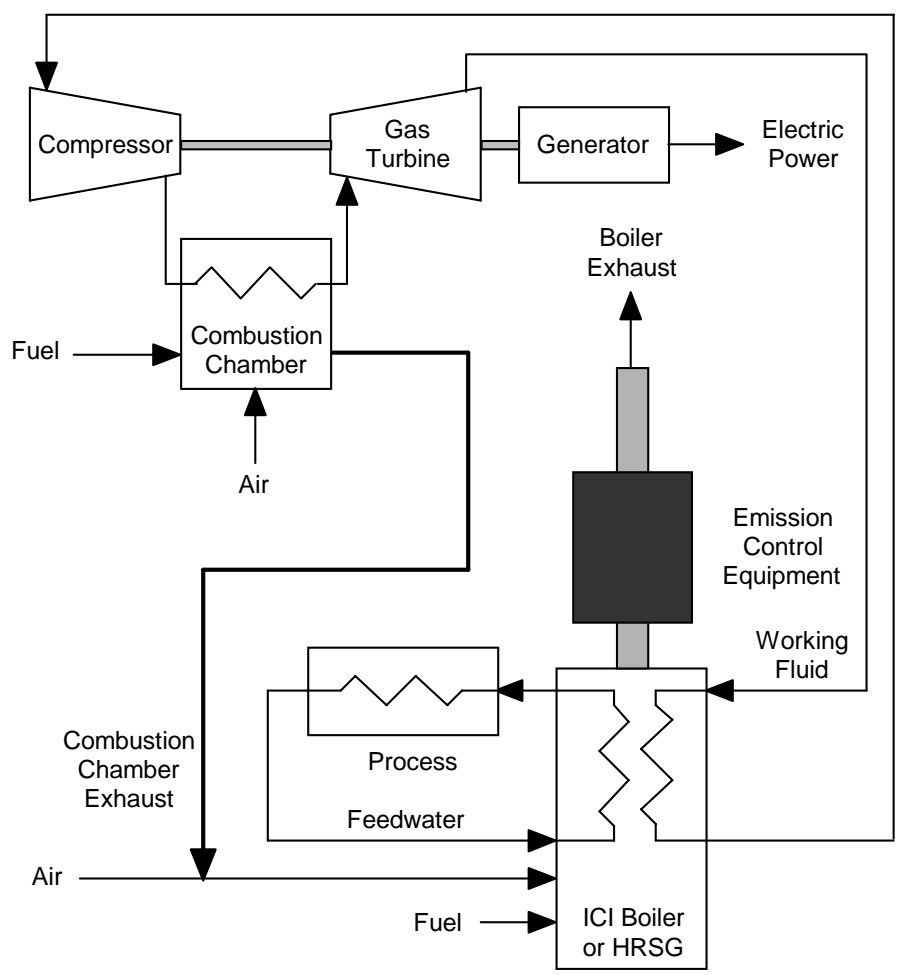

Fig. 7.7. Configuration of a closed-cycle gas turbine topping-cycle CHP system (without regenerator) for ICI boiler applications. 


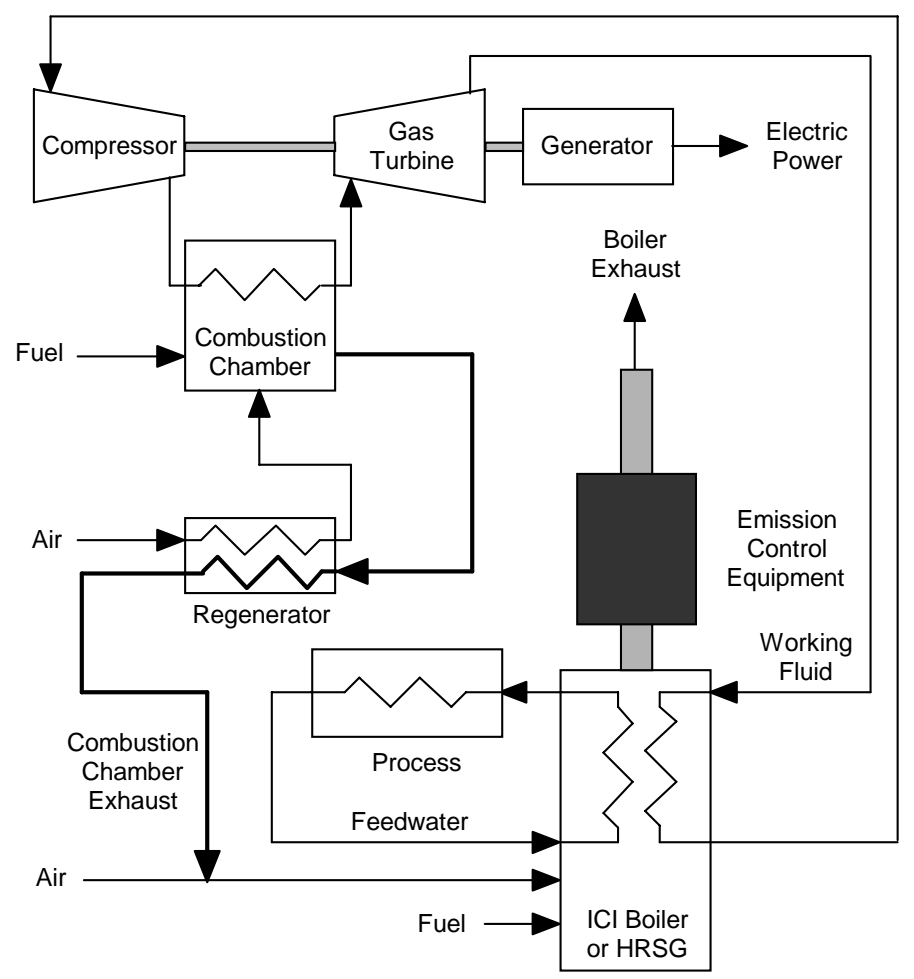

Fig. 7.8. Configuration of a closed-cycle gas turbine topping-cycle CHP system (with regenerator) for ICI boiler applications.

Closed-cycle gas turbines are physically smaller than those for comparable size open-cycle systems, but require more piping and heat exchangers. In addition, the small physical size of the turbine machinery limits the power of closed-cycle turbines. For these reasons, CHP systems that are based on this technology and have capacities below $500 \mathrm{~kW}$ may not be economically attractive. Electric generating capacity for most closed-cycle gas turbine CHP systems ranges from 2 to $50 \mathrm{MW}$ (Ref. 5).

Heat-recovery units used in closed-cycle gas turbine CHP systems also serve two functions by recovering waste heat from the working fluid and providing additional heat needed to meet process demands. Although almost any type of fired heat-recovery unit that burns solid, liquid, or gaseous fuels can be use in closed-cycle gas turbine CHP systems, two other important issues need to be considered when integrating closed-cycle gas turbine CHP equipment into existing installations.

1. Recovering waste heat from a closed-cycle gas turbine may require changing the boiler or HRSG configuration to allow heat transfer from the working fluid. Modifications could involve adding additional heat transfer surfaces or converting some of the existing heat transfer surfaces to the working fluid circuit. Assessing the feasibility of these changes, identifying design options and modification alternatives, and understanding the impacts of change on performance may require separate engineering studies.

2. Boilers and HRSGs that are supplied with a mixture of combustion air and gas turbine exhaust must be capable of handling the high-temperature combustion products present in the exhaust. Depending on the composition of the fuel burned in the gas turbine, the exhaust gas may contain oxygen, $\mathrm{NO}_{\mathrm{x}}$, $\mathrm{CO}_{2}$, and $\mathrm{CO}$ as well as unburned hydrocarbons and VOCs. Due to potential combustion control and operating problems, effects of these gases on performance and emissions need to be assessed on a case-by-case basis. It should also be recognized that exposure to high-temperature exhaust gases must 
be considered in the design and construction of regenerators and combustion chambers used in closed-cycle gas turbine systems.

From an operational viewpoint, the overall fuel efficiency of closed-cycle gas turbine CHP systems is comparable to that of open-cycle systems. In addition, the closed-cycle configuration reduces wear and tear on the turbine blades. Consequently, reliability and average annual availability of closed-cycle gas turbines should be at least as good as that for open-cycle systems. Before serious consideration is given to closed-cycle gas turbine technology, boiler owners and operators need to be aware that there are currently no commercial suppliers of closed-cycle gas turbine systems in the United States. Experience with these systems is primarily based in several European countries. ${ }^{5}$

\subsubsection{Reciprocating Engine Topping Systems}

Principal components in reciprocating engine topping-cycle CHP systems include the reciprocating internal combustion engine, heat-recovery equipment, and electrical generator. In operation, the engine turns a generator that produces electric power, while the heat-recovery equipment captures waste heat from the engine. Internal combustion engines reject heat from the following sources: radiation from the engine block and other hot surfaces, exhaust gases, lubricating oil, jacket water, and, for turbocharged and aftercooled engines, the engine aftercooler. By recovering heat rejected from the exhaust and cooling systems, approximately 70 to $80 \%$ of the energy in the fuel can be recovered and used for power production or process heating applications. ${ }^{8}$

Engine exhaust up to $1,000^{\circ} \mathrm{F}$ or higher represents from 30 to $50 \%$ of the available waste heat that can be used to produce hot water, and low- or high-pressure steam. This heat is sometimes recovered using a heat exchanger known as a heat-recovery muffler. These mufflers are designed to reduce noise transmitted in the exhaust gases and to generate hot water or steam up to $150 \mathrm{psig}$. In ICI boiler applications, heat recovered by the muffler can be used to increase the temperature of the boiler feedwater or for other process applications. Because reciprocating engines do not operate with large quantities of excess air, the oxygen content of the exhaust is relatively low (typically $7 \%$ to $8 \%$ ) compared to the oxygen content of combustion turbine exhaust. ${ }^{7}$ Consequently, mixing engine exhaust gases with boiler combustion air as a way to recover waste heat may not be practical, especially when the combustion system creates excessive back-pressure on the engine.

Heat in the engine coolant system accounts for up to $30 \%$ of the energy input. Much of this heat can be recovered using either a forced coolant circulation system or an ebullient cooling system that recovers heat from the engine cooling water to produce hot water or steam at a maximum pressure of $15 \mathrm{psig}$. In addition, separate heat exchangers are sometimes used to recover lower temperature heat (usually less than $160^{\circ} \mathrm{F}$ ) rejected from the engine by the lubricating oil system and aftercoolers.

The configuration of a typical reciprocating engine topping-cycle CHP system for boiler applications is shown in Fig. 7.9. Depending on the application, it may be possible to integrate the waste heat-recovery equipment into a single system that uses exhaust and coolant heat for steam production. Additional information about heat-recovery units for CHP applications is presented in Sect. 2.1.2.

The CI diesel-cycle engines and SI Otto-cycle are the two primary reciprocating engine designs commonly used for stationary power generation applications. Their sizes typically range from about $20 \mathrm{~kW}$ to more than $10 \mathrm{MW}$ (Ref. 5). Although CI diesel engines are among the most efficient simplecycle power generation options, their use in the United States is increasingly restricted to emergency standby or limited-duty service because of air emission concerns. Natural-gas-fueled SI engines are now the preferred choice for the higher-duty-cycle power generation applications. 


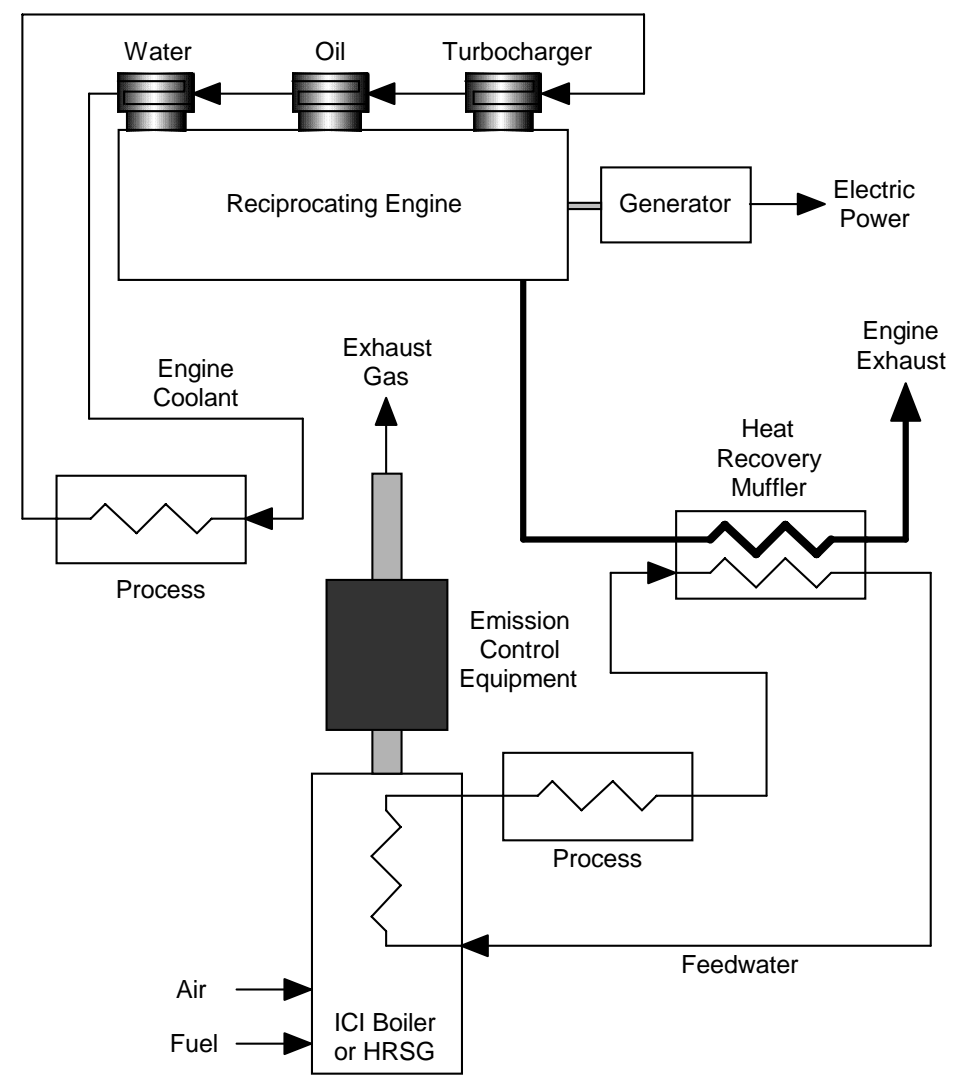

Fig. 7.9. Configuration of a reciprocating engine topping-cycle CHP system for ICI boiler applications.

Diesel engines, which represent fully developed and mature technology, are sometimes used as prime movers in many reciprocating engine topping-cycle CHP systems. These engines normally burn light fuel oil, but some diesel engines are designed to burn either heavy fuel oil, natural gas, or natural gas with a small percentage of diesel oil as pilot fuel. SI engines used in electric power generation and CHP applications generally burn natural gas, but other gaseous and volatile liquid fuels ranging from landfill gas to propane to gasoline can be used with the proper fuel system, engine compression ratio, and controls. Additional information about the various types of reciprocating engines that are available for CHP applications is presented in Sect. 3.4.

\subsubsection{Fuel Cell Topping Systems}

A fuel cell is an electrochemical device that converts the chemical energy of a fuel into electricity with no intermediate combustion cycle. Hydrogen and oxygen react to produce water in the presence of an electrolyte and, in doing so, generate an electrochemical potential that drives a current through an external circuit. In addition, the reaction produces waste heat. Hydrogen used by the cell is obtained from fossil fuels, usually methane. Because methane occurs naturally only in natural gas, fuel conversion is necessary if coal or biomass are the ultimate sources of the hydrogen.

Fuel cells may be attractive for industrial and commercial CHP applications or for utility peaking applications because of their modular construction, good electric load following capabilities without a loss in efficiency, low emissions, and quiet operation. An individual fuel cell has an electric potential of slightly less than $1 \mathrm{~V}$ (determined by the electrochemical potential of the hydrogen and oxygen reaction), but single cells can be assembled in series to generate practically any desired voltage, and these 
assemblies, in turn, can be connected in parallel to provide a variety of power levels (e.g., $40 \mathrm{~kW}$ to $25 \mathrm{MW}$ ). A fuel cell power plant includes the cell stack, an inverter to convert dc to ac, and a fuel process to remove impurities from the hydrocarbon fuel and convert it to pure hydrogen. Thermal energy recovered from a fuel cell can be either all hot water, or part steam and part hot water depending on the pressure. In ICI boiler applications, the recovered heat can be used to increase the temperature of the feedwater that returns from the process. The configuration of a fuel cell topping-cycle CHP system for an ICI boiler application is shown in Fig. 7.10.

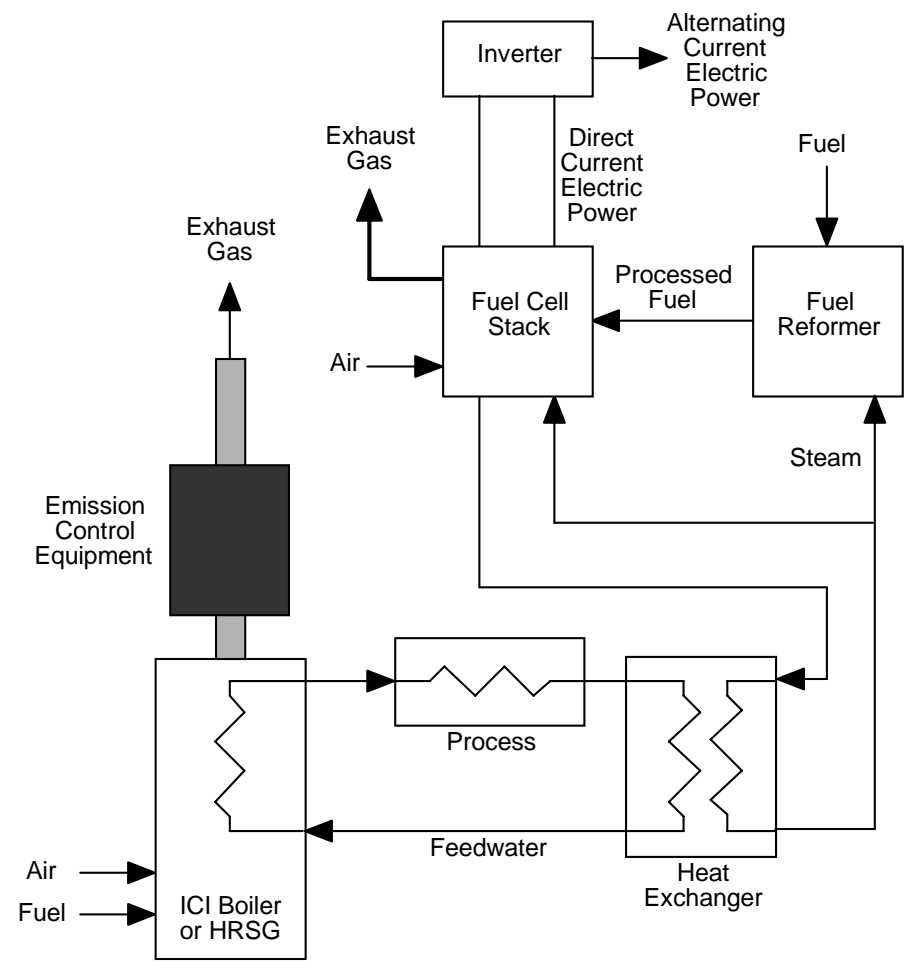

Fig. 7.10. Configuration of a fuel cell toppingcycle CHP system for ICI boiler applications.

\subsubsection{Microturbine Topping Systems}

A microturbine is a compact gas turbine consisting of a compressor, recuperator, combustion chamber or combustor, and turbine. Microturbine topping-cycle CHP systems operate on the same thermodynamic cycle as larger open-cycle gas turbine topping systems described in Sect. 7.1.2.1. In this cycle, atmospheric air is compressed, heated, and then expanded, with the net power produced by the turbine used for power generation. The power produced by an expansion turbine and consumed by a compressor is proportional to the absolute temperature of the gas passing through those devices. Consequently, it is advantageous to operate the expansion turbine at the highest practical temperature consistent with economic materials and to operate the compressor with inlet airflow at as low a temperature as possible. As technology advances permit higher turbine inlet temperature, the optimum pressure ratio also increases. Higher temperature and pressure ratios result in higher efficiency and specific power. Thus, the general trend in gas turbine advancement has been toward a combination of higher temperatures and pressures. However, microturbine inlet temperatures are generally limited to 
$1,800^{\circ} \mathrm{F}$ or below to enable the use of relatively inexpensive materials for the turbine wheel and to maintain pressure ratios at a comparatively low 3.5 to 4.0 (Ref. 9).

Like large gas turbines, microturbines run at high speeds and can be used in power-only generation or in CHP systems. Electricity is produced by either a high-speed generator that rotates on a single turbocompressor shaft at up to $96,000 \mathrm{rpm}$ or with a separate power turbine that drives a gearbox connected to a conventional 3,600-rpm generator. High-speed generators produce high-frequency ac output that must be converted to $60 \mathrm{~Hz}$ for general use. This power conditioning involves rectifying the high-frequency ac to $\mathrm{dc}$, and then inverting the dc to $60-\mathrm{Hz}$ ac.

Microturbines are able to operate on a variety of fuels, including natural gas, sour gases (high sulfur, low Btu content), and liquid fuels, such as gasoline, kerosene, and diesel fuel/distillate heating oil. In resource recovery applications, they burn waste gases that would otherwise be flared or released directly into the atmosphere. The size for microturbines ranges from 30 to about $350 \mathrm{~kW}$.

Recuperators in microturbines serve as heat exchangers that use the energy in the hot exhaust gases to preheat the compressed air before it enters the combustor. By reducing the fuel needed to heat the compressed air to the turbine inlet temperature, recuperators can more than double the efficiency. Although recuperators effectively improve efficiency, they lower the temperature of the microturbine exhaust, thereby reducing the amount of heat available for process applications, and they increase the pressure drop in both the compressed air and turbine exhaust sides of the recuperator, resulting in a $10 \%$ to $15 \%$ decrease in power output compared to microturbines without recuperators.

Thermal output from microturbines ranges from 400 to $600^{\circ} \mathrm{F}$. This heat can be used to produce hot water or steam for process applications or to preheat boiler feedwater. For ICI boiler applications, the exhaust gases can be mixed with combustion air and supplied to the boiler where the recovered heat is used to produce additional hot water or steam for process applications. Figure 7.11 shows the

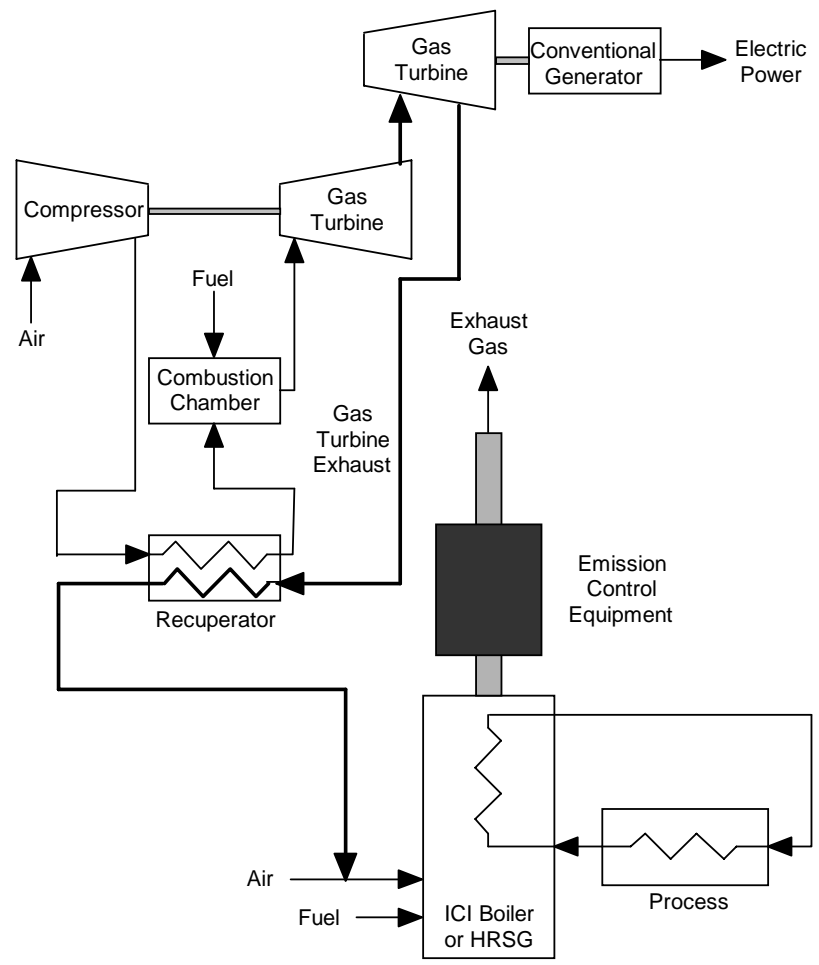

Fig. 7.11. Configuration of a microturbine toppingcycle CHP system (with conventional generator) for ICI boiler applications. 
configuration of a microturbine topping-cycle CHP system for ICI boiler applications with a gearbox and conventional generator for producing $60-\mathrm{Hz}$ ac power. An alternative configuration is shown in Fig. 7.12 for a microturbine with a high-speed generator. This system includes power electronics for converting high-frequency power to $60-\mathrm{Hz}$ ac power for general use.

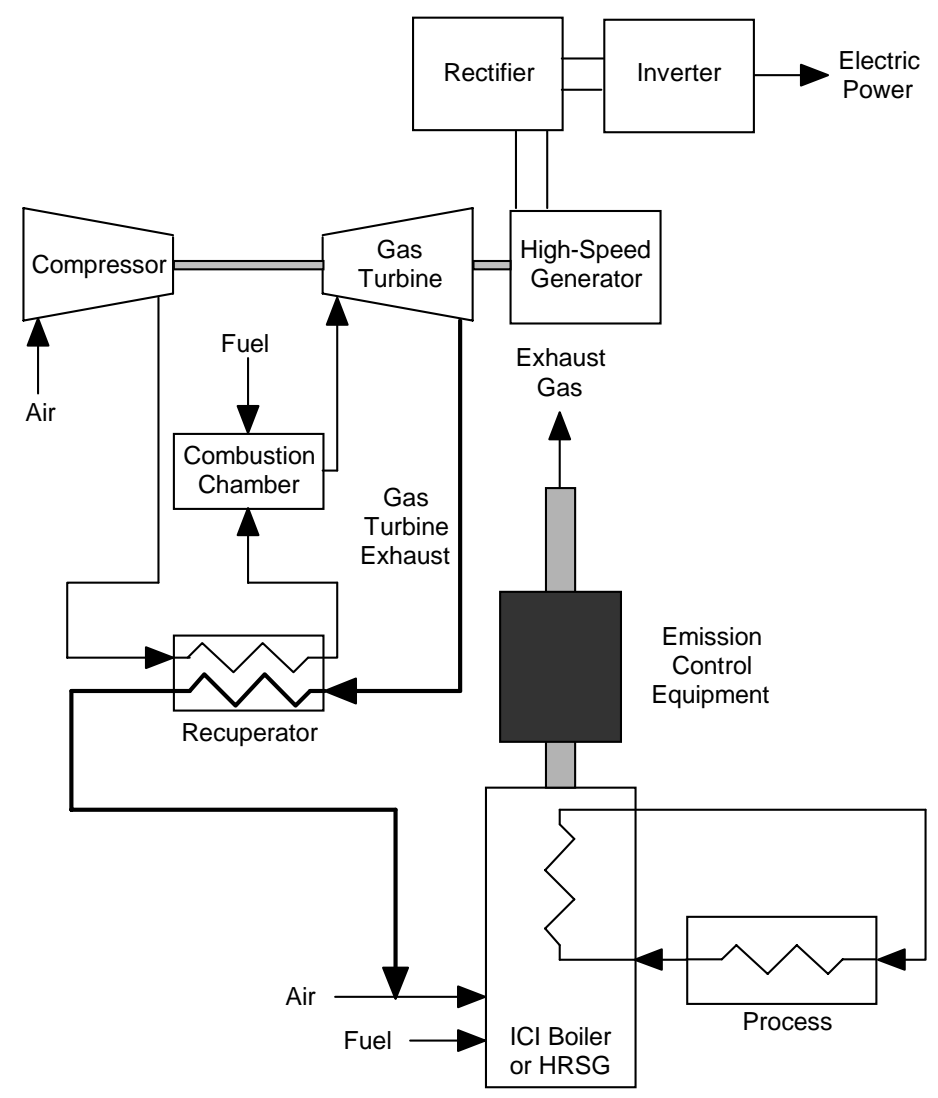

Fig. 7.12. Configuration of a microturbine toppingcycle CHP system (with high-speed generator) for ICI boiler applications.

\subsection{BOTTOMING-CYCLE SYSTEMS}

For bottoming-cycle CHP systems, energy is first used in a thermal process such as a smelting furnace that derives heat from electric heating elements, combustion of fossil fuels, landfill gas, RDF, or another energy source. Waste heat from the thermal process becomes the heat source for the CHP system. In a typical bottoming-cycle CHP system, heat recovery from the thermal process is accomplished in a HRSG as shown in Fig. 7.13. Steam produced in the HRSG flows to a steam turbine that turns an electrical generator or another type of rotating machinery. Heat rejected from the steam turbine is then made available for other process heating applications. Like steam turbine topping-cycle CHP systems discussed in Sect. 7.1.1, back-pressure and extraction-condensing steam turbines can be used in bottoming-cycle applications. The bottoming-cycle CHP system shown in Fig. 7.13 represents only one of many possible bottoming-cycle configurations that can be developed.

Bottoming-cycle CHP systems are generally only suitable for industries where high-temperature waste heat is readily available. Consequently, most CHP systems are based on either the topping cycle or 


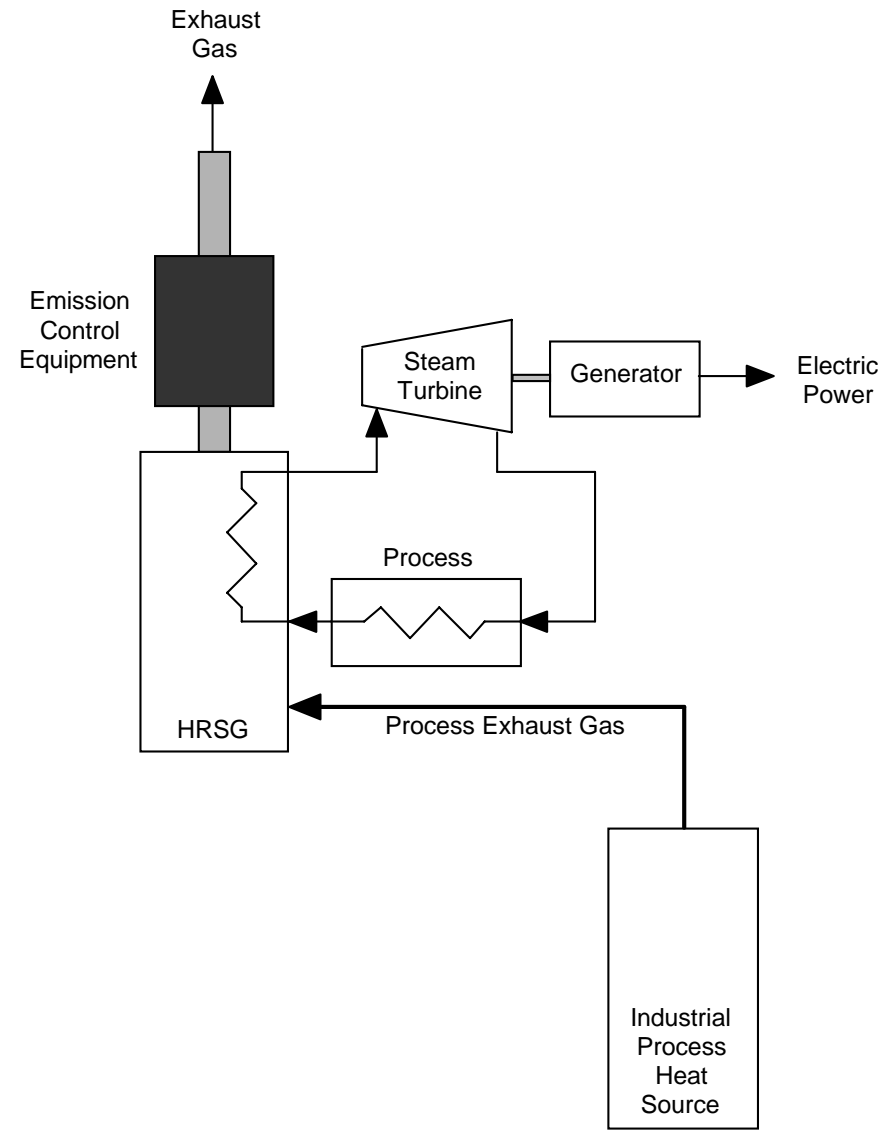

\section{Fig. 7.13. Configuration of a bottoming-cycle CHP system for ICI boiler applications.}

combined cycle, which uses heat from a topping cycle as the energy source for a bottoming cycle. Information about combined-cycle systems is presented in Sect. 7.3.

The cost of a bottoming-cycle CHP system using a steam turbine is roughly comparable to the cost for a comparable size topping-cycle CHP system because most of the components are the same for both systems. ${ }^{5}$ Maintenance requirements and reliability for the steam turbine bottoming systems are comparable to those of steam turbine topping systems with average annual availability of up to about $90 \%$, but this value is directly influenced by the availability of heat from the thermal process. Although there are other bottoming-cycle systems, such as organic bottoming cycles that use different working fluids, these systems are beyond the scope of this guide.

\subsection{COMBINED-CYCLE SYSTEMS}

Combined-cycle CHP systems have two interconnected cycles operating at different temperatures. The higher temperature topping cycle rejects heat that is recovered and used in the lower temperature bottoming cycle to produce additional power and improve overall conversion efficiency. Major components of a combined-cycle CHP system are the gas turbine and its electrical generator, the ICI boiler or HRSG, and the steam turbine and its electrical generator.

Heat recovery from the gas turbine exhaust is accomplished either by mixing the exhaust gases with fresh combustion air or by using the energy in the hot exhaust to increase the temperature of boiler or HRSG feedwater. Two possible configurations of combined-cycle CHP systems that use an open-cycle 
gas turbine topping system and a steam turbine bottoming system are shown in Figs. 7.14 and 7.15. Note that these systems are similar to the open-cycle gas turbine CHP system discussed in Sect. 7.1.2.1 except that steam from the boiler or HRSG is used first to generate electricity and then exhausted for process heating applications.

When a recuperator is added to the topping cycle, the system has a slightly different configuration as shown in Fig. 7.16. Combined-cycle CHP systems can also be assembled using closed-cycle gas turbine topping systems and steam turbine bottoming systems. Either of the closed-cycle systems shown in Figs 7.7 and 7.8 could be used for these applications.

In most combined-cycle CHP systems, extra fuel is burned in the boiler or HRSG to supplement the heat in the gas turbine exhaust. The high percentage of oxygen (normally 15\%) in the gas turbine exhaust enables efficient supplemental combustion. Supplemental firing generally improves thermal efficiency at part-load operation, but it makes combined-cycle plant operation control more complex. Fuels suitable for use in combined-cycle CHP systems are the same as those used for commercial gas turbines-natural gas, light distillate oil, and other fuels that are free from contaminants. Heavy fuels, such as residual oil, heavy distillates, and coal-derived fuels that are contaminated with trace metals can be used provided they are first cleaned. Systems that use indirect firing and heat exchangers (i.e., closed cycles) can operate on a

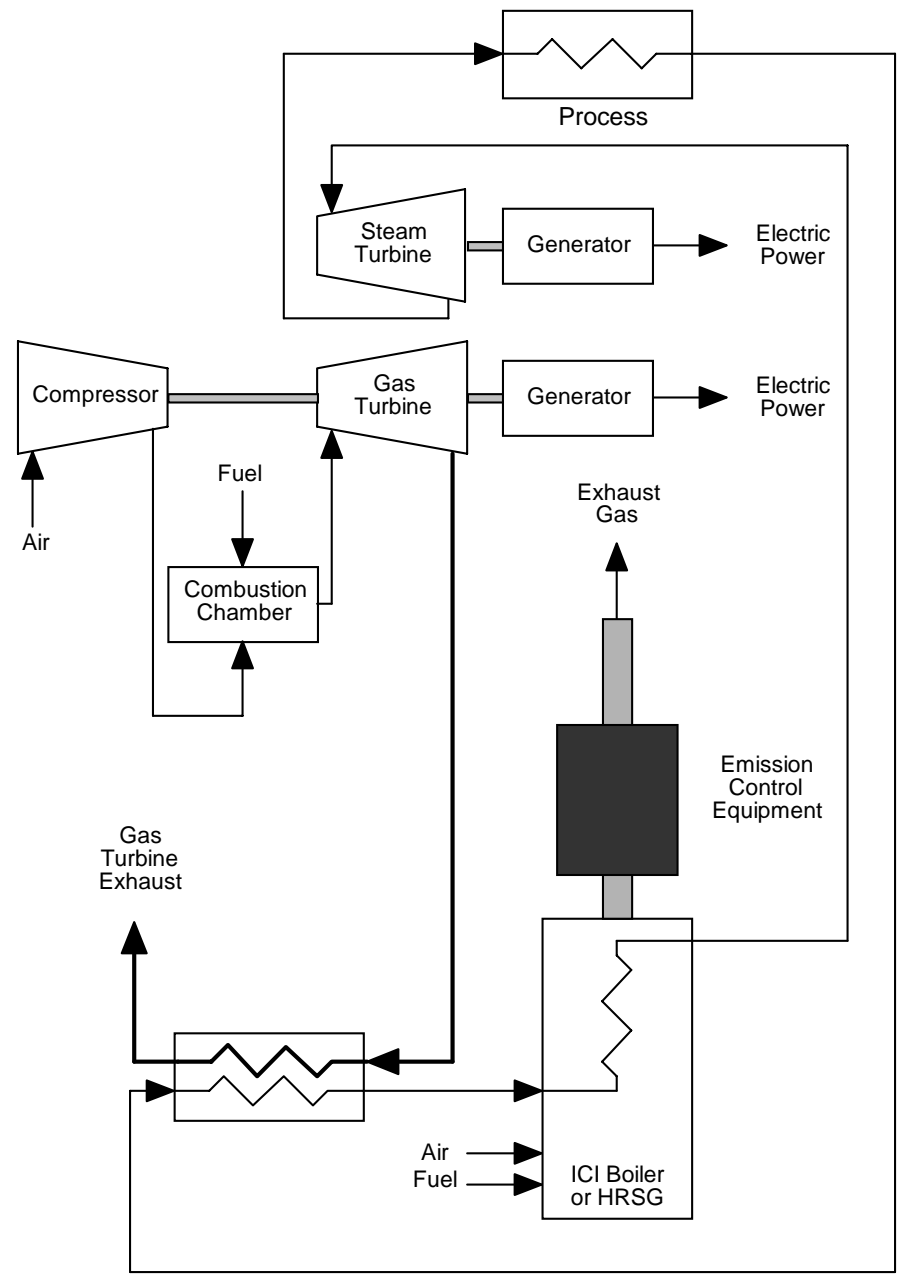

Fig. 7.14. Configuration of a combined-cycle CHP system (with feedwater preheat) for ICI boiler applications. 


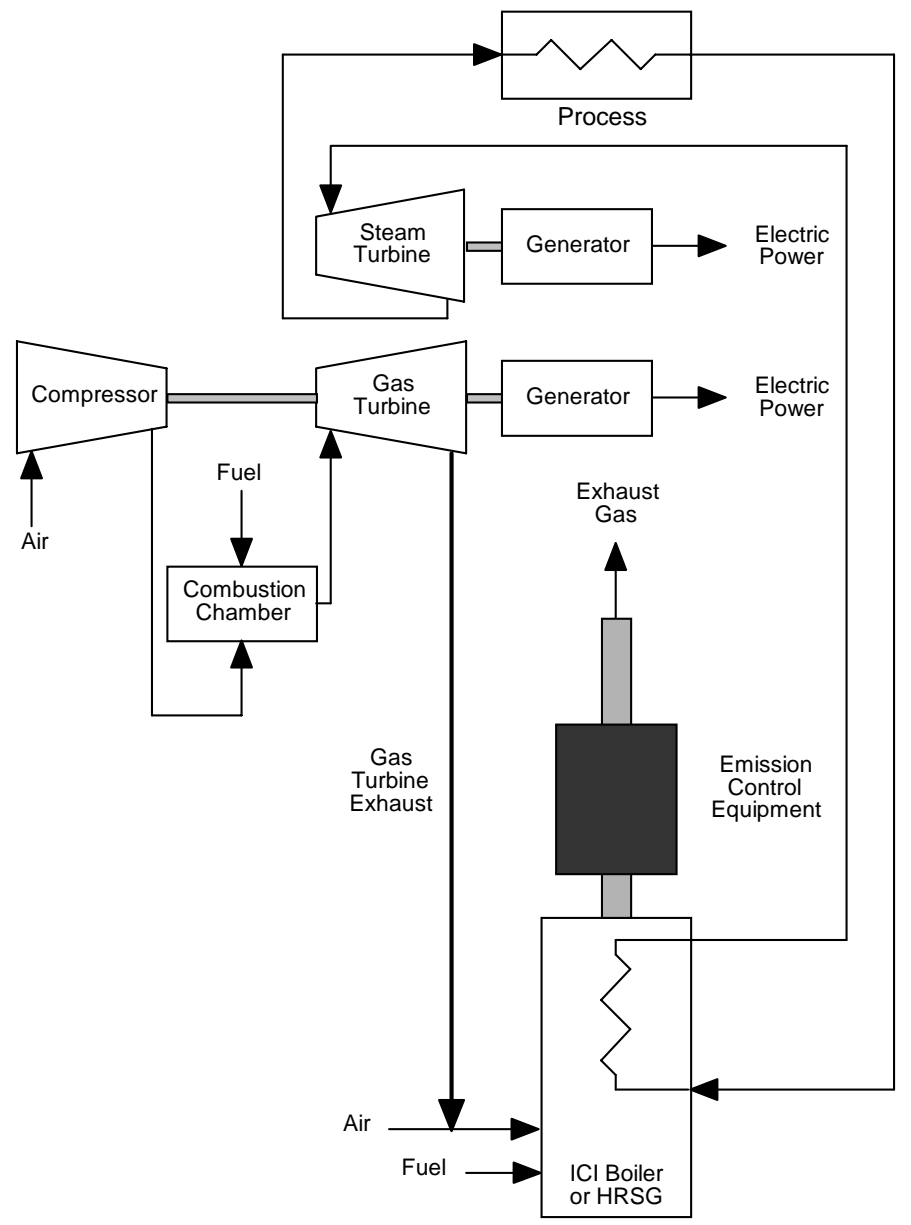

Fig. 7.15. Configuration of a combined-cycle CHP system (with exhaust gas heat recovery) for ICI boiler applications. 


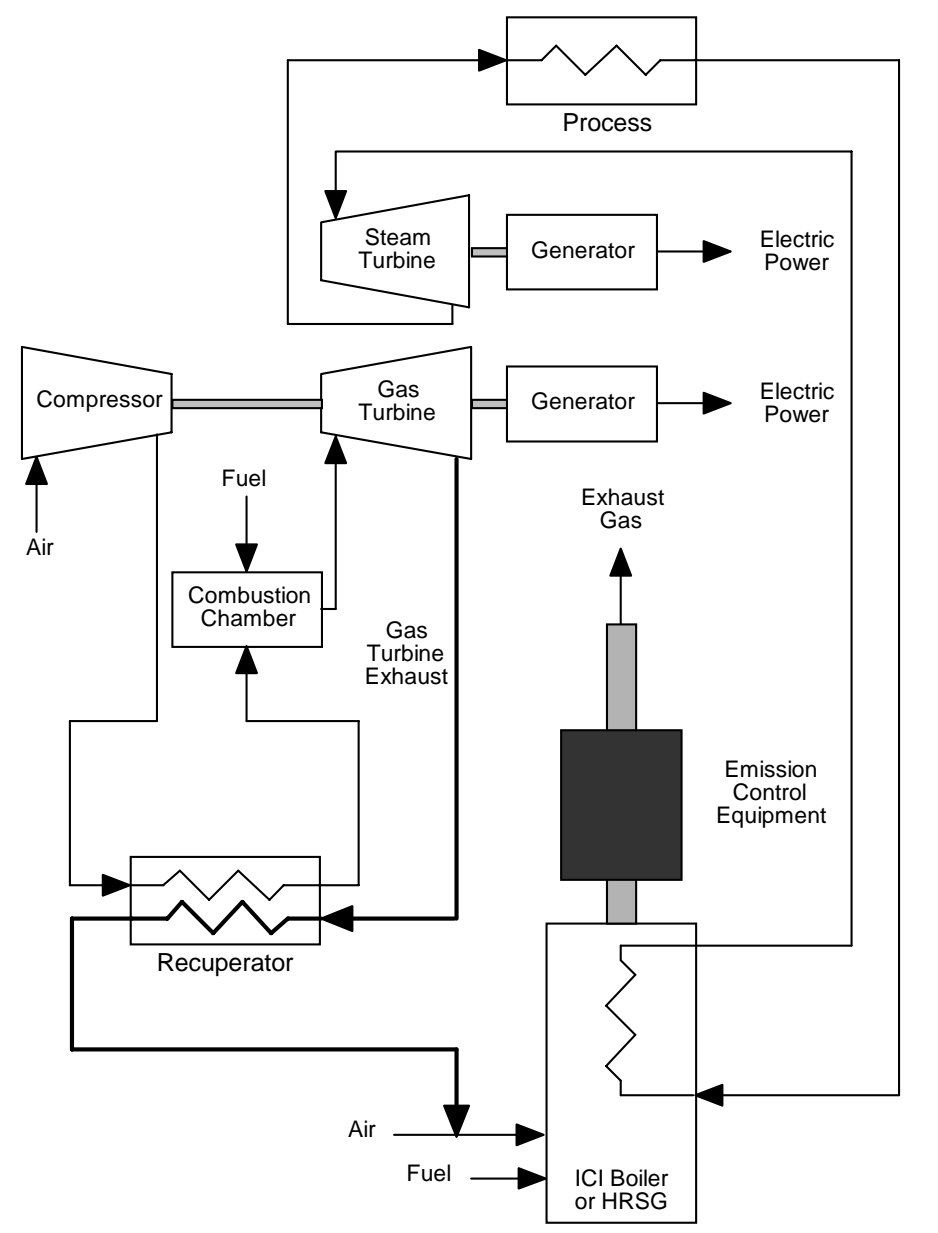

Fig. 7.16. Configuration of a combined-cycle CHP system (with recuperator) for ICI boiler applications.

wider variety of fuels, because the gas turbine blades are isolated from the corrosive influence of the combustion products. Combined-cycle systems that incorporate fluidized bed combustors are able to burn coal or almost any other fuel.

Combined-cycle CHP systems are typically available in sizes ranging from 22 to about $400 \mathrm{MW}$ and often require less floor space than separate combustion and steam turbines producing comparable amounts of electric power. Reduced space requirements can be an advantage in integrating CHP technology into existing boiler installations. 5

The electric generating efficiency of combined-cycle CHP systems is greater than for simple gas turbine CHP systems because of the additional electricity generated by the steam turbine. Current combined-cycle systems achieve electric generating efficiencies between 34 and 40\%, with $37 \%$ being typical. ${ }^{5}$ Gas turbines equipped with waste heat boilers typically achieve net thermal fuel efficiencies higher than $80 \%$ by recovering energy in the gas turbine exhaust. As with open-cycle gas turbine CHP systems, part-load operation reduces the efficiency of combined-cycle CHP systems. When gas turbine generating efficiency drops, more waste heat is supplied to the steam turbine and its percentage of electric load increases. However, the overall efficiency declines because of the increasing amount of waste heat from part-load operation that cannot be recovered. 
Typical electricity-to-steam ratios for combined cycles range from 175 to $320 \mathrm{kWh} / \mathrm{MMBtu}$. This is significantly higher than those for steam turbine topping-cycle CHP systems that range from 30 to $75 \mathrm{kWh} / \mathrm{MMBtu}$ and comparable to or slightly higher than open-cycle gas turbine CHP systems that range from 140 to $225 \mathrm{kWh} / \mathrm{MMBtu}$. However, as the E/S ratio in a combined-cycle system increases, the overall fuel efficiency decreases. 5

Gas turbines represent a larger percentage of the prime mover installed costs than do the steam turbines in these systems. Maintenance costs for the combined-cycle system are influenced by the type of

fuel used. The lowest maintenance costs are associated with natural gas use, while using residual oil in the gas turbine will result in the highest maintenance costs, primarily because of the necessity to clean the fuel. Maintenance requirements for a combined-cycle system are similar to those for the separate turbines, and average annual availability is lower than for either technology alone (77 to $85 \%$ ). Reliability is around 80 to $85 \%$. Economic service life is between 15 and 25 years. However, as with open-cycle gas turbines, poor maintenance, lower quality fuels, and intermittent operation will decrease the availability, reliability, and service life.

\subsection{TRIGENERATION}

Trigeneration is the concept of deriving three different forms of energy from the primary fuel source, namely, heating, cooling, and electric power generation. Systems based on this concept are particularly relevant at facilities that need air-conditioning and for industries that require process cooling. A typical trigeneration facility consists of a cogeneration plant and a vapor absorption chiller that uses heat recovered from the CHP system to produce chilled water for cooling applications. The configuration of a trigeneration system that integrates a vapor absorption chiller into a gas turbine topping-cycle CHP system is shown in Fig. 7.17. Using a similar approach, it is possible to develop different trigeneration configurations such as the one shown in Fig. 7.18 based on other CHP systems.

Although cooling can be provided by conventional vapor compression chillers driven by electric motors, low-quality heat (i.e., low temperature, low pressure) exhausted from CHP systems can power absorption chillers so that the overall primary energy consumption is reduced. Absorption chillers are designed to extract heat in the evaporator, which is placed in the space to be cooled, and reject this heat in the condenser. Vapor absorption chillers, which are widely used in Japan and China, are gradually gaining acceptance in the United States and are being integrated into CHP systems. In general, they are larger and more expensive than electric-driven chillers, and direct-fired chillers are more expensive to operate when electricity rates are relatively low. However, they are gaining acceptance as a means for controlling electricity demand charges, and it is expected that this use will become more widespread on waste-heat fired systems as cogeneration technology gains acceptance. 


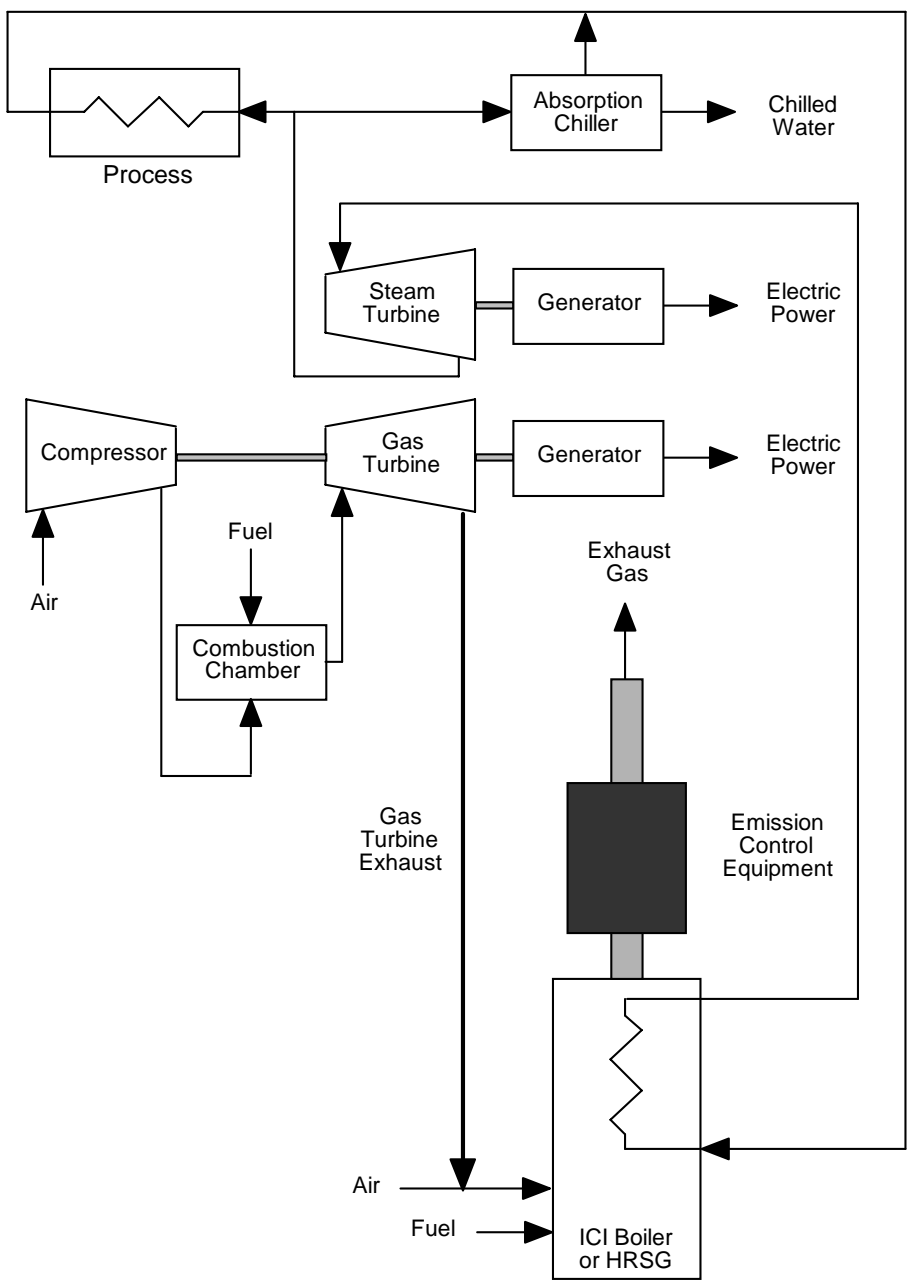

Fig. 7.17. Configuration of a trigeneration system for ICI boiler applications. 


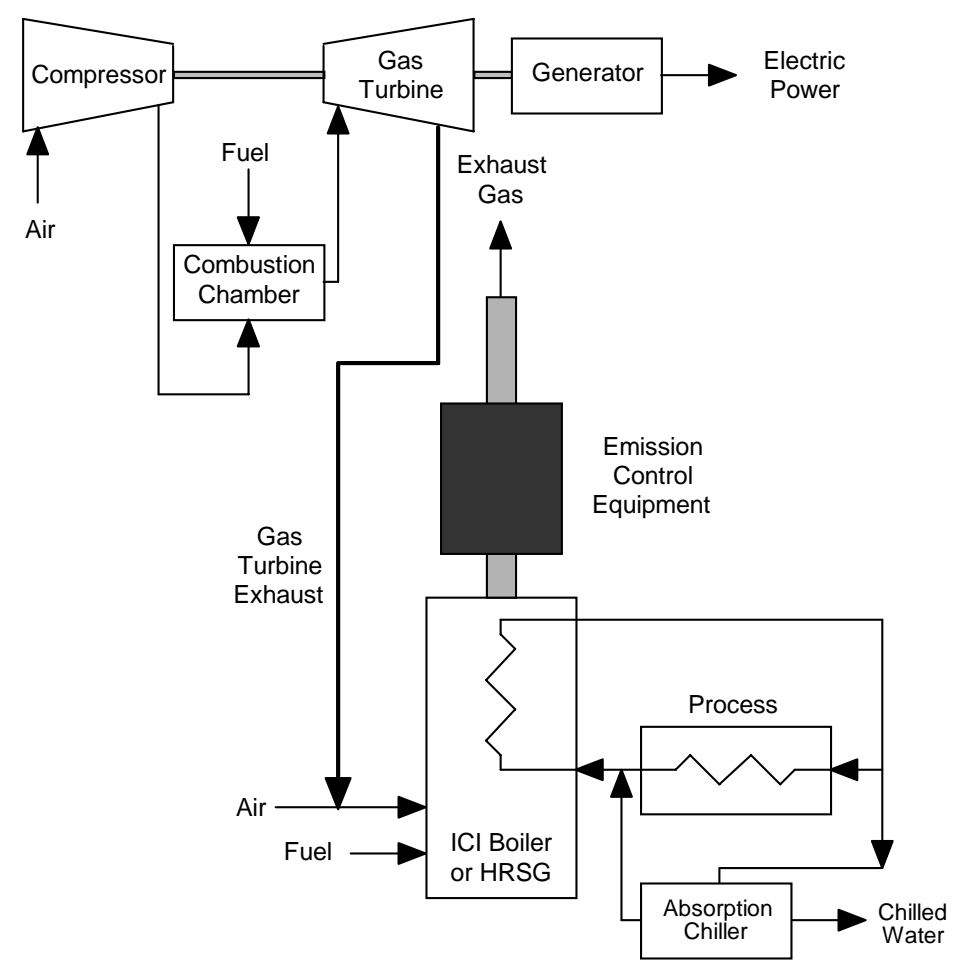

Fig. 7.18. Alternative configuration of a trigeneration system for ICI boiler applications.

\subsection{REFERENCES}

1. Combustion Fossil Power, 4th ed., ed. J. G. Singer, Combustion Engineering, Inc., Windsor, Connecticut, 1991.

2. Steam, Its Generation and Use, 40th ed., eds. S. C. Stultz and J. B. Kitto, Babcock and Wilcox, Barberton, Ohio, 1992.

3. R. Hite, Cogeneration/Combined Heat and Power: An Overview, Cogeneration and Competitive Power Journal, ed., F. W. Payne, Vol. 17, No. 3, Summer 2002, pp. 64-79.

4. Performance Test Code on Overall Plant Performance, ASME PTC 46-1996, American Society of Mechanical Engineers, New York, 1996.

5. Industrial and Commercial Cogeneration, Office of Technology Assessment, Congressional Board of the 98th Congress, Washington, D.C., February 1983.

6. Combined Heat and Power: A Federal Manager's Resource Guide, prepared by Aspen Systems Corp. for the U.S. Department of Energy, Washington, D.C., March 2000.

7. J. A. Orlando, Cogeneration Design Guide, American Society of Heating, Refrigerating and AirConditioning Engineers, Inc., Atlanta, Georgia, 1996.

8. Technology Characterization: Reciprocating Engines, prepared by Energy Nexus Group for the U.S. Environmental Protection Agency, Washington, D.C., February 2002.

9. Technology Characterization: Microturbines, prepared by Energy Nexus Group for the U.S. Environmental Protection Agency, Washington, D.C., March 2002. 


\section{PRELIMINARY DESIGN CONSIDERATIONS}

Boiler owners and operators interested in incorporating cogeneration technology into new or existing ICI boiler installations must first develop a preliminary design of the system. This design should include CHP equipment that is compatible with the physical characteristics and operating objectives of the facility. Developing preliminary designs for CHP systems that satisfy these criteria requires consideration of thermodynamic cycles, prime movers, fuels, and heat-recovery equipment options. The following discussions provide boiler owners and operators with technical options for developing preliminary designs.

\subsection{THERMODYNAMIC CYCLES}

As discussed in Chap. 7, heat-recovery schemes are categorized as either topping- or bottomingcycle systems, depending on the sequence in which the fuel is used. Topping-cycle systems typically use heat to produce electricity and then for process applications. Bottoming-cycle systems use energy in the opposite sequence. When topping- and bottoming-cycle systems are combined, they create a dual-cycle system known as a combined cycle. Most combined-cycle systems have the ability to generate electricity and heat; but when other equipment is added to the system that produces a cooling effect, a trigeneration system is created. Selecting an appropriate thermodynamic cycle or cycle combination is the first step in the preliminary design process. Information presented in Table 8.1 identifies some of the more important factors to consider when choosing the appropriate thermodynamic cycle or cycle combination.

\subsection{PRIME MOVER SELECTION}

Steam turbines, gas turbines, microturbines, and reciprocating engines are commonly used as prime movers in CHP applications to convert energy into work. These machines along with fuel cells are used to create topping-cycle, combined-cycle, and trigeneration CHP systems. A comparison of prime mover design and performance characteristics is presented in Table 3.1.

The goal of any CHP system is to recover as much heat from the prime mover as possible and make it available for useful purposes. Although the recovered heat is often used for steam and hot water production, the heat can also be used for process heating, space heating, and direct heating applications. When a cooling effect is needed, recovered heat can be used by absorption chillers and desiccant dehumidifiers as discussed in Sects. 6.1, and 6.2, respectively.

Mechanical energy produced by steam turbines, gas turbines, and reciprocating engines in CHP applications is generally used to power an electrical generator. However, this energy can also be used to power fans, pumps, air compressors, and refrigeration compressors. Additional information about these rotating machines and their potential for use in CHP applications is presented in Sect. 6.3.

Selecting a prime mover for a particular CHP application generally involves consideration of many factors. ${ }^{1,2}$ Some of the more important issues to consider include:

- the facility's thermal and electrical load profile,

- primary and secondary fuel sources,

- air quality and emission control requirements,

- physical space limitations,

- acceptable noise levels,

- the ability of the prime mover to match the heat and power requirements of the facility,

- the decision whether to parallel with the electrical grid or be totally independent, 
Table 8.1. Factors to consider in choosing an appropriate thermodynamic cycle

\begin{tabular}{|c|c|c|}
\hline Thermodynamic cycle & New installations & Existing installations \\
\hline \multirow[t]{3}{*}{ Topping } & $\begin{array}{l}\text { New ICI boiler or fired HRSG } \\
\text { installations that produce high-pressure } \\
\text { steam are ideally suited for integration } \\
\text { into a steam turbine topping-cycle CHP } \\
\text { system. }\end{array}$ & $\begin{array}{l}\text { Existing ICI boiler and HRSG } \\
\text { installations that use pressure-reducing } \\
\text { valves are ideal candidates for } \\
\text { integration into a steam turbine } \\
\text { topping-cycle CHP system. }\end{array}$ \\
\hline & $\begin{array}{l}\text { New ICI boiler or fired HRSG } \\
\text { installations that can be used to recover } \\
\text { heat from gas turbines, microturbines, } \\
\text { reciprocating engines, or fuel cells are } \\
\text { candidates for use in topping-cycle } \\
\text { CHP systems. }\end{array}$ & $\begin{array}{l}\text { Existing ICI boiler and HRSG } \\
\text { installations that need to produce } \\
\text { additional steam or hot water, should } \\
\text { consider supplementing existing } \\
\text { capacity with either a gas turbine, } \\
\text { microturbine, reciprocating engine, or } \\
\text { fuel cell topping-cycle CHP system. }\end{array}$ \\
\hline & & $\begin{array}{l}\text { Installations with existing ICI boilers or } \\
\text { fired HRSGs that can be modified to } \\
\text { recover heat from gas turbines, } \\
\text { microturbines, reciprocating engines, or } \\
\text { fuel cells are candidates for integration } \\
\text { into CHP topping-cycle systems. }\end{array}$ \\
\hline Bottoming & $\begin{array}{l}\text { If a new installation includes an } \\
\text { independent heat source such as a } \\
\text { furnace or kiln, consider integrating the } \\
\text { heat source into a steam turbine } \\
\text { bottoming-cycle CHP system. Heat } \\
\text { recovered from the process can be used } \\
\text { to produce steam, increase the } \\
\text { temperature of feedwater, or preheat } \\
\text { combustion air. }\end{array}$ & $\begin{array}{l}\text { If the installation has an independent heat } \\
\text { source such as a furnace or kiln that } \\
\text { produces high-temperature exhaust } \\
\text { gases and it is possible to recover heat } \\
\text { from the exhaust gas stream in a heat- } \\
\text { recovery device such as an unfired } \\
\text { HRSG or heat exchanger, consider } \\
\text { integrating the heat source into a steam } \\
\text { turbine bottoming-cycle CHP system. }\end{array}$ \\
\hline Combined & $\begin{array}{l}\text { New ICI boiler or fired HRSG } \\
\text { installations that are capable of using } \\
\text { the mechanical and thermal energy } \\
\text { generated by gas turbines, } \\
\text { microturbines, or reciprocating engines } \\
\text { are candidates for use in combined- } \\
\text { cycle CHP systems. }\end{array}$ & $\begin{array}{l}\text { Existing ICI boiler or fired HRSG } \\
\text { installations that are capable of using } \\
\text { the mechanical and thermal energy } \\
\text { generated by gas turbines, } \\
\text { microturbines, or reciprocating engines } \\
\text { are candidates for integration into } \\
\text { combined-cycle CHP systems. }\end{array}$ \\
\hline Trigeneration & $\begin{array}{l}\text { If a combined-cycle system is a viable } \\
\text { option and a cooling effect is required, } \\
\text { consider a trigeneration CHP system. }\end{array}$ & $\begin{array}{l}\text { If a combined-cycle system is a viable } \\
\text { option and a cooling effect is required, } \\
\text { consider a trigeneration CHP system. }\end{array}$ \\
\hline
\end{tabular}

- the decision whether to sell excess power to the local utility,

- the preferred and alternative operating strategies for the CHP system (see Sect. 2.4.1),

- the importance of sizing the prime mover to the thermal base load,

- the availability and reliability requirements of the system. 
When considering generating capacity, it is important to recognize that any imbalance in heat requirements results in burning supplemental fuels or wasting surplus recovered heat through the heatrejection system. To minimize waste of thermal energy, the CHP system can be sized to track the electrical load profile up to the generator capacity, which is selected for a thermal output that matches the valley of the thermal profile. Under these conditions, when the thermal load exceeds the generator's profile valley, supplemental electricity can be purchased from the utility, or thermal energy can be produced by other means.

For boiler owners and operators with high-pressure steam systems, a variety of applications favor steam turbines over gas turbines and reciprocating engines. In topping-cycle applications, it may be more cost-effective to use steam turbines as a replacements for pressure-reducing valves as compared to installing another type of prime mover. If facilities that have low-pressure steam distribution systems, back-pressure or extraction turbines can be applied. Steam turbines can also be used quite effectively in combined-cycle applications. ${ }^{2}$ Use of low-cost fuels to generate the steam needed to power steam turbines often gives steam turbines economic advantages over rival gas turbine and reciprocating engine systems.

Compared to reciprocating engines, the economic performance of gas turbines improve when power is produced continuously at full load, high-temperature thermal energy is needed at the site, and system capacity is high. Conversely, economic performance of reciprocating engines improves when operations are not continuous or loads vary, lower temperature thermal energy is needed at the site, and capacity requirements decrease. Although more expensive to install, fuel cells may have advantages over gas turbine and reciprocating engine systems in areas with stringent emission control requirements.

\subsection{FUEL AND EMISSION CONTROL ISSUES}

Fuel availability is a key issue that can significantly influence thermodynamic cycle and prime mover selection decisions. For example, installations that only have access to solid fuel are generally limited to topping- and bottoming-cycle steam turbine CHP systems, but when liquid fuels are available, topping-cycle and combined-cycle CHP systems based on gas turbine, microturbine, and reciprocating engine technology become possible. Although access to liquid fuels increases the number of available options, other fuel issues such as transportation and on-site storage need to be considered. Gaseous fuels represent the most versatile fuel option. They can be supplied to the site on demand, they do not require on-site storage, they burn cleanly, and they produce relatively low levels of regulated air pollutants. Gaseous fuels are available in most, but not all, areas of the United States. Natural gas, which is a suitable gaseous fuel for all types of prime movers used in any thermodynamic cycle, is the preferred fuel choice for most new CHP applications.

The type and amount of emissions released into the atmosphere when fuel is burned depend primarily on the chemical composition of the fuel and the way the fuel is burned. In general, combustion of solid fuels and residual oils tends to produce more types of emissions than combustion of distillate oils and gaseous fuels. Emissions of primary concern to CHP system owners and operators include

- $\mathrm{NO}_{\mathrm{x}}$,

- $\mathrm{SO}_{2}$,

- PM,

- $\mathrm{CO}$,

- HAP, and

- VOC.

Discussions about environmental regulations and emission standards for air and water pollutants are presented in Sect. 2.3.1. Understanding these regulations and knowing which techniques are available for 
controlling emission levels is an important part of the preliminary design process, and environmental compliance is key to obtaining construction and operating permits from federal, state, or local environmental regulatory authorities.

Techniques available for reducing air emissions are subdivided into the following categories.

- Precombustion,

- Combustion, and

- Postcombustion.

Emission control techniques that can be applied to ICI boilers and fired HRSGs are presented in Tables 4.4-4.6. Corresponding information about emission control options for gas turbines, microturbines, reciprocating engines, and fuels cell are presented in Sects. 3.2.2.6, 3.3.2.6, 3.4.2.6, and 3.5.2.6, respectively.

The cost of CHP fuel, which can be as much as $60 \%$ to $80 \%$ of the system's operating cost, ${ }^{3}$ is the predominant factor in establishing CHP economic viability. Fuel price and its fluctuations are also important because they have a direct impact on the production cost of electricity. Inexpensive fuels such as wood waste make ideal fuels for CHP applications if they are readily available near the site and do not require treatment prior to combustion. The unit cost of electricity generated by their combustion is often much less than the unit cost of electricity purchased from the utility. As the difference between the generated and purchased cost of electricity increases, the more likely the CHP will be economically viable. A useful tool for screening economic viability of natural-gas-powered CHP systems is available in the Combined Heat and Power (CHP) Resource Guide. ${ }^{4}$ This spreadsheet tool compares the average cost difference between electricity and natural gas to identify CHP systems with favorable payback potential.

As the cost of fuel for the CHP system increases, the payback period lengthens, and, at some point, cogeneration becomes uneconomical. Estimated simple payback periods for natural-gas-powered CHP systems with different installation costs are presented in Tables 8.2 and 8.3. Corresponding payback periods for oil-powered CHP systems are presented in Tables 8.4 and 8.5. Trends for other fuels and other installation costs follow a similar pattern.

Review of data in Tables 8.2 through 8.5 suggests that a payback period of 2 years or less is only possible when (1) the average cost of electricity purchased from the utility is comparatively high or (2) the average cost of fuel for the CHP system is comparatively low. The data also indicate that fuel cost and electricity price combinations produce no cost savings. These undesirable conditions tend to occur whenever fuel costs are high or electricity costs are low. Using this type of a simple payback analysis can help identify whether economic benefits can be derived by installing a CHP system. In situations where no economic benefit can be derived, continuation of CHP planning needs to be based on reasons other than economics.

\subsection{HEAT-RECOVERY SCHEMES}

Heat recovery is an essential part of a CHP system. The role of the heat-recovery equipment is to make heat that would otherwise be waste available for useful work. Rejected heat from prime movers and other heat sources can be recovered in either unfired or fired heat-recovery equipment. These various types of heat-recovery equipment are commonly used in CHP applications:

- unfired HRSG,

- heat-recovery muffler,

- regenerator,

- recuperator,

- ebullient cooling system, 


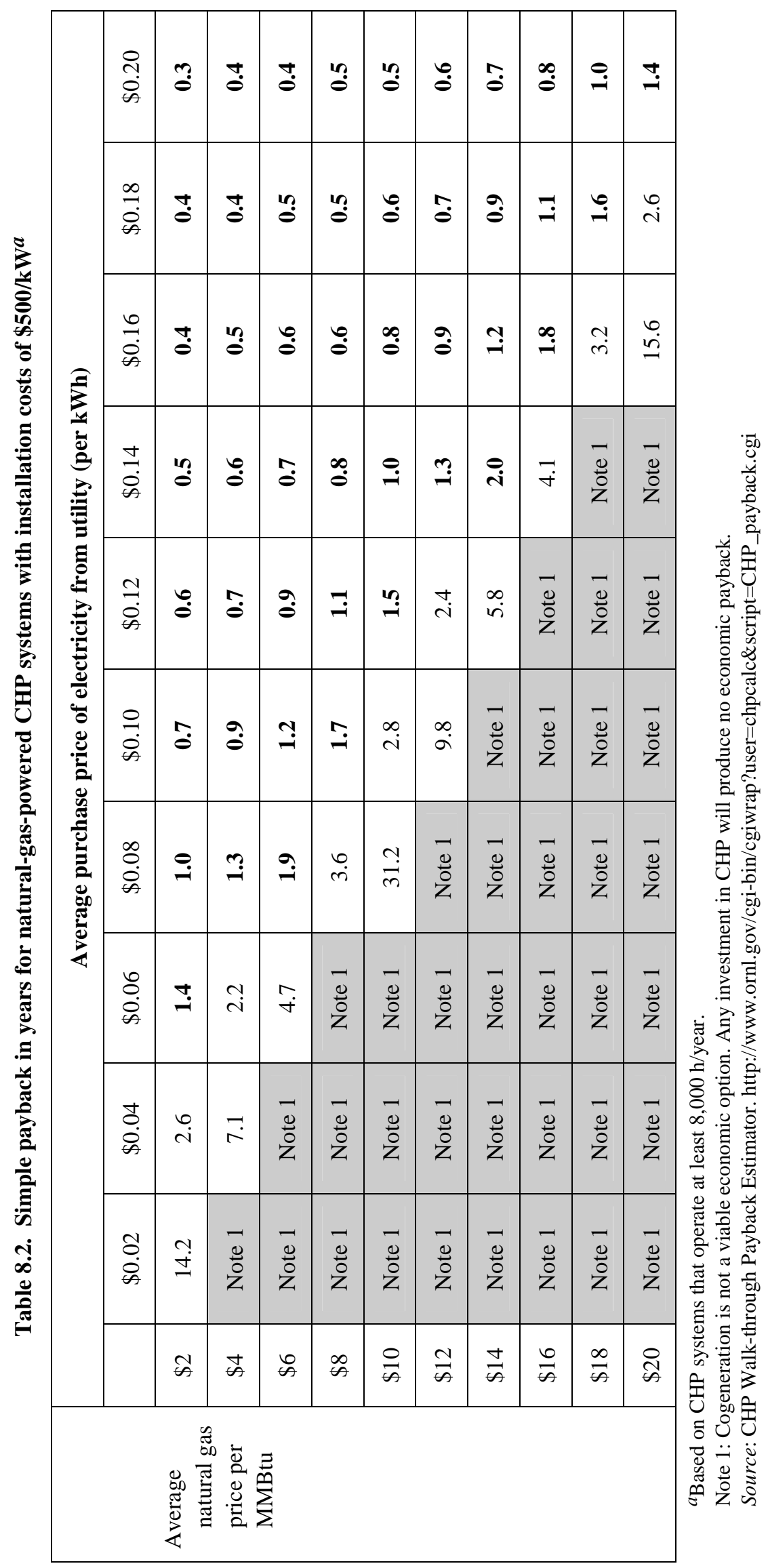




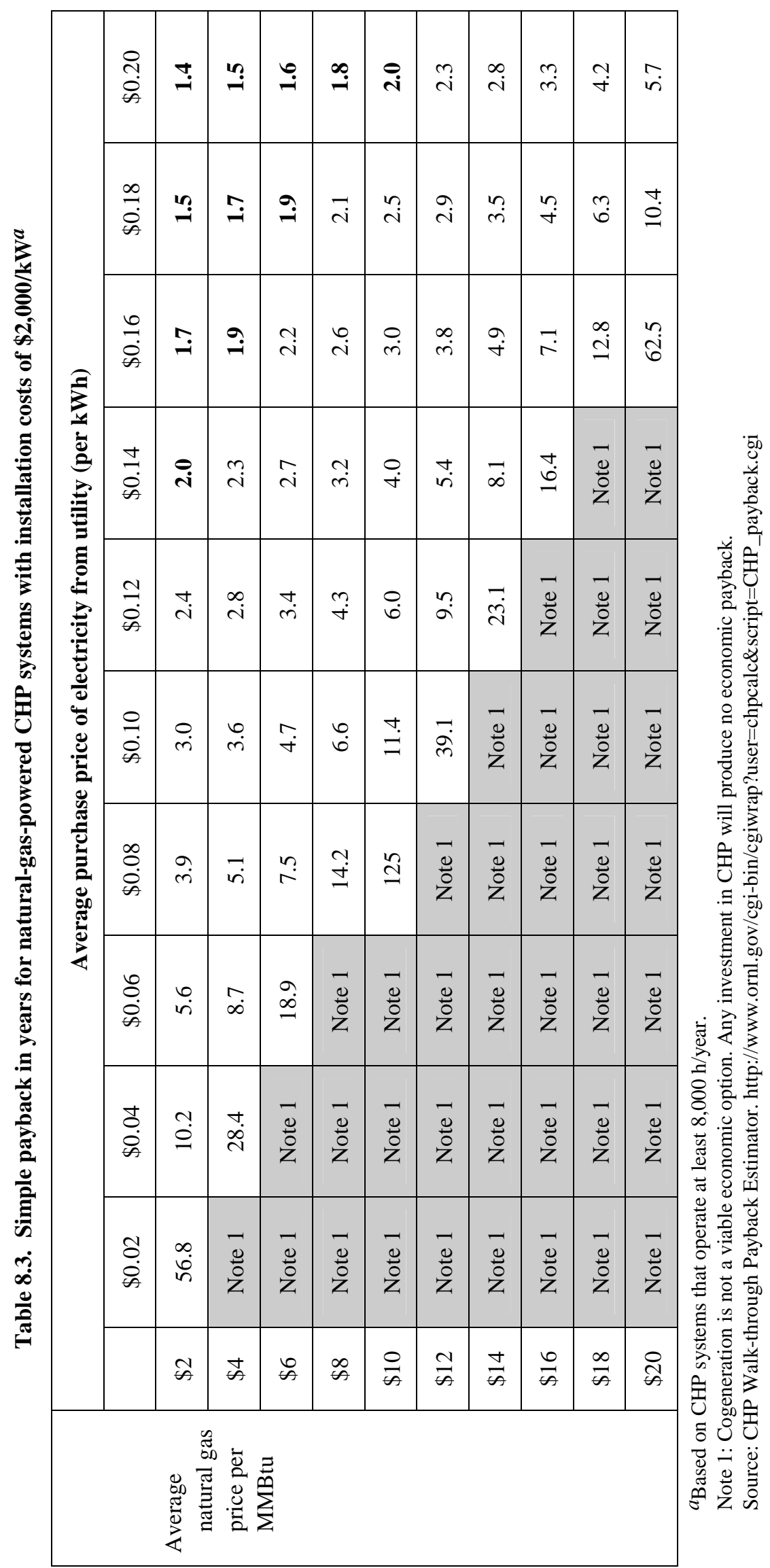




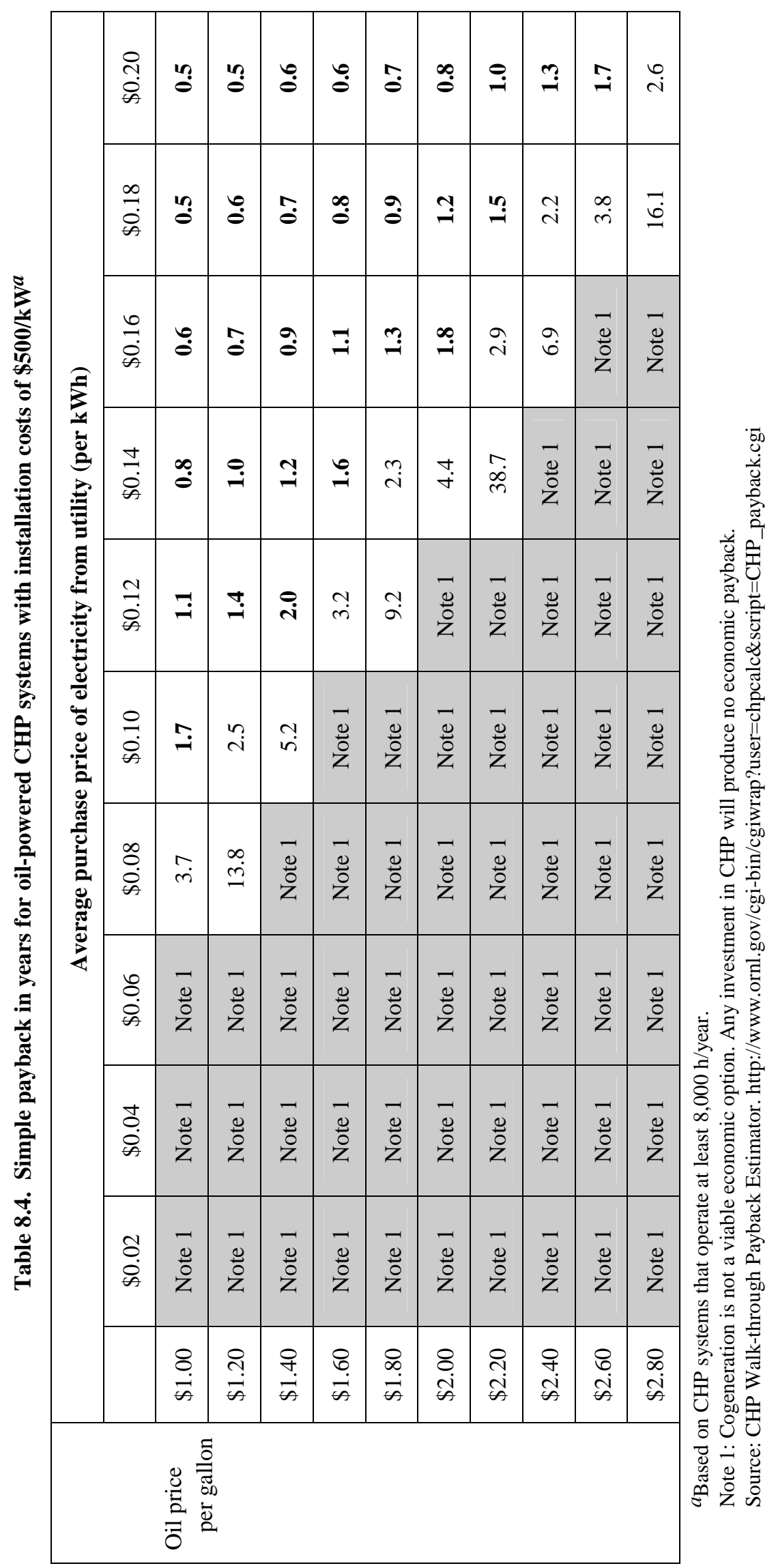




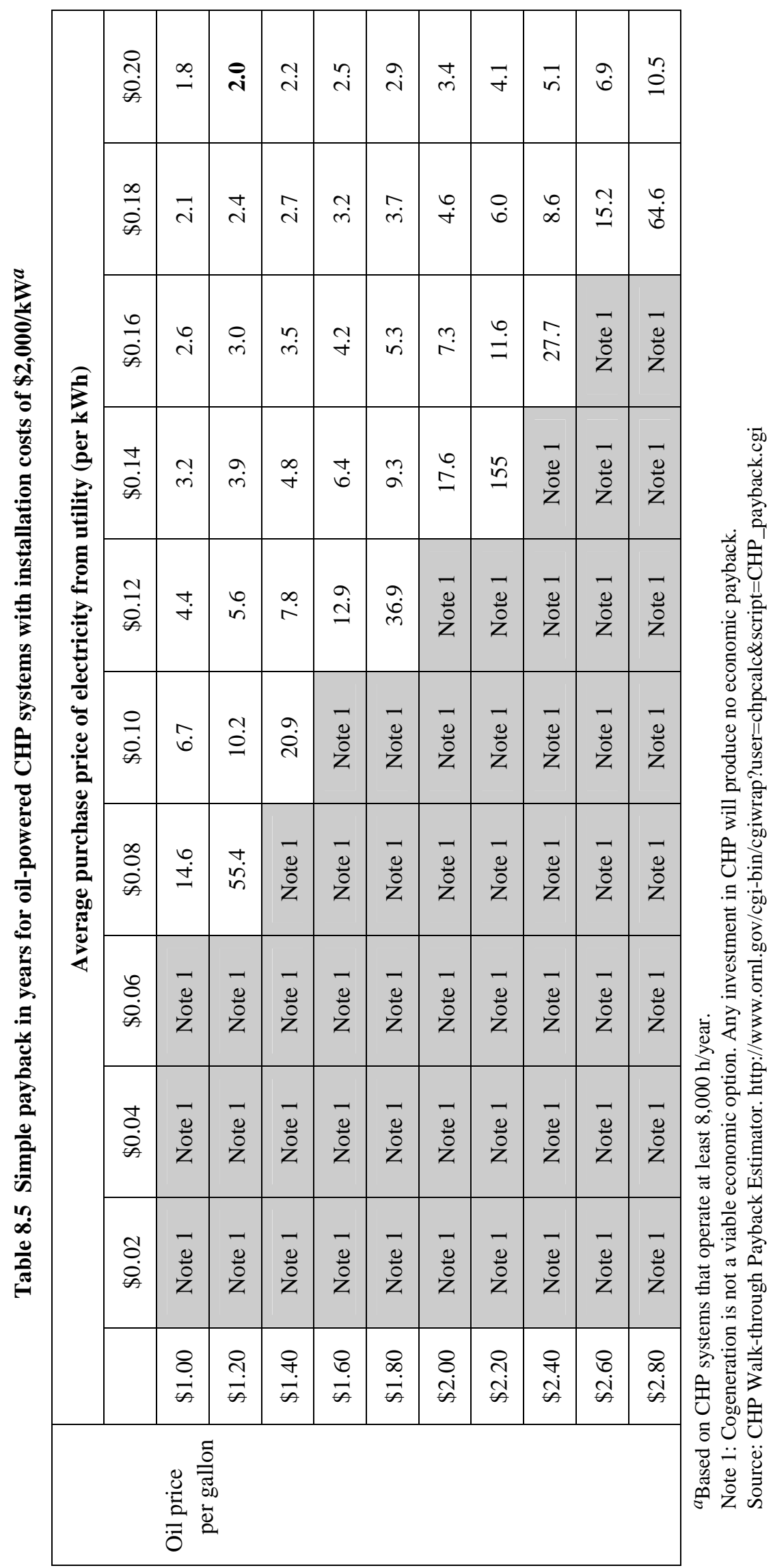


- forced circulation system,

- aftercooler,

- heat exchanger,

- supplementary fired heat recovery steam generator, and

- ICI boiler.

Additional information about these heat-recovery devices is presented in Chap. 4.

\subsection{CHP OPTIONS}

Preliminary designs for CHP systems can be developed by first selecting a thermodynamic cycle and a prime mover and then choosing appropriate heat-recovery equipment. To help identify the various factors that should be considered and the equipment options that are available for developing preliminary designs, a series of diagrams has been prepared. These diagrams list the heat-recovery equipment options, fuel options, options for using mechanical and thermal energy, potential air emissions, and emission control options for the following 12 CHP systems:

- Topping-cycle CHP systems

$\checkmark$ Back-pressure steam turbine CHP system (Fig. 8.1)

$\checkmark$ Extraction-condensing steam turbine CHP system (Fig. 8.2)

$\checkmark$ Open-cycle gas turbine CHP system without recuperator (Fig. 8.3)

$\checkmark$ Open-cycle gas turbine CHP system with recuperator (Fig. 8.4)

$\checkmark$ Microturbine CHP system with conventional generator (Fig. 8.5)

$\checkmark$ Microturbine CHP system with high-speed generator (Fig. 8.6)

$\checkmark$ Reciprocating engine CHP system (Fig. 8.7)

$\checkmark \quad$ Fuel cell CHP system (Fig. 8.8)

- Bottoming-cycle CHP system (Fig. 8.9)

- Combined-cycle CHP systems

$\checkmark$ CHP system (Fig. 8.10)

$\checkmark$ CHP system with feedwater heating (Fig. 8.11)

- $\quad$ Trigeneration CHP system (Fig. 8.12)

Because these diagrams were developed primarily for boiler owners and operators, all of the CHP systems include either an ICI boiler or a fired or unfired HRSG. Diagrams for CHP systems based on closed-cycle gas turbine technology, discussed in Sect. 7.1.2.2, were not prepared because these systems are currently not available in the United States. Many other CHP system configurations could be developed, if necessary, but these 12 systems represent those most likely to be considered by boiler owners and operators for new or existing installations. 


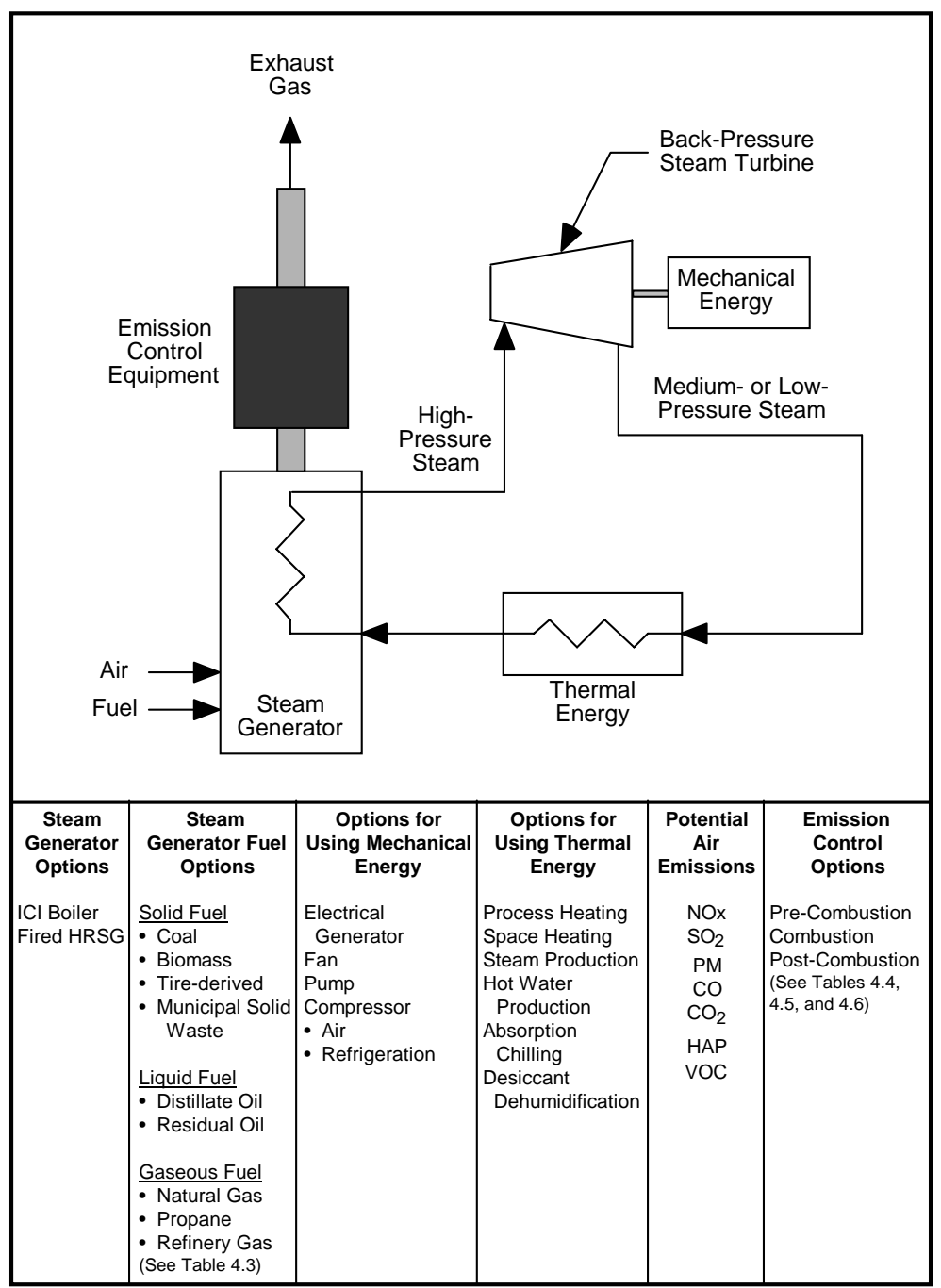

Fig. 8.1. Back-pressure steam turbine topping-cycle CHP system options. 


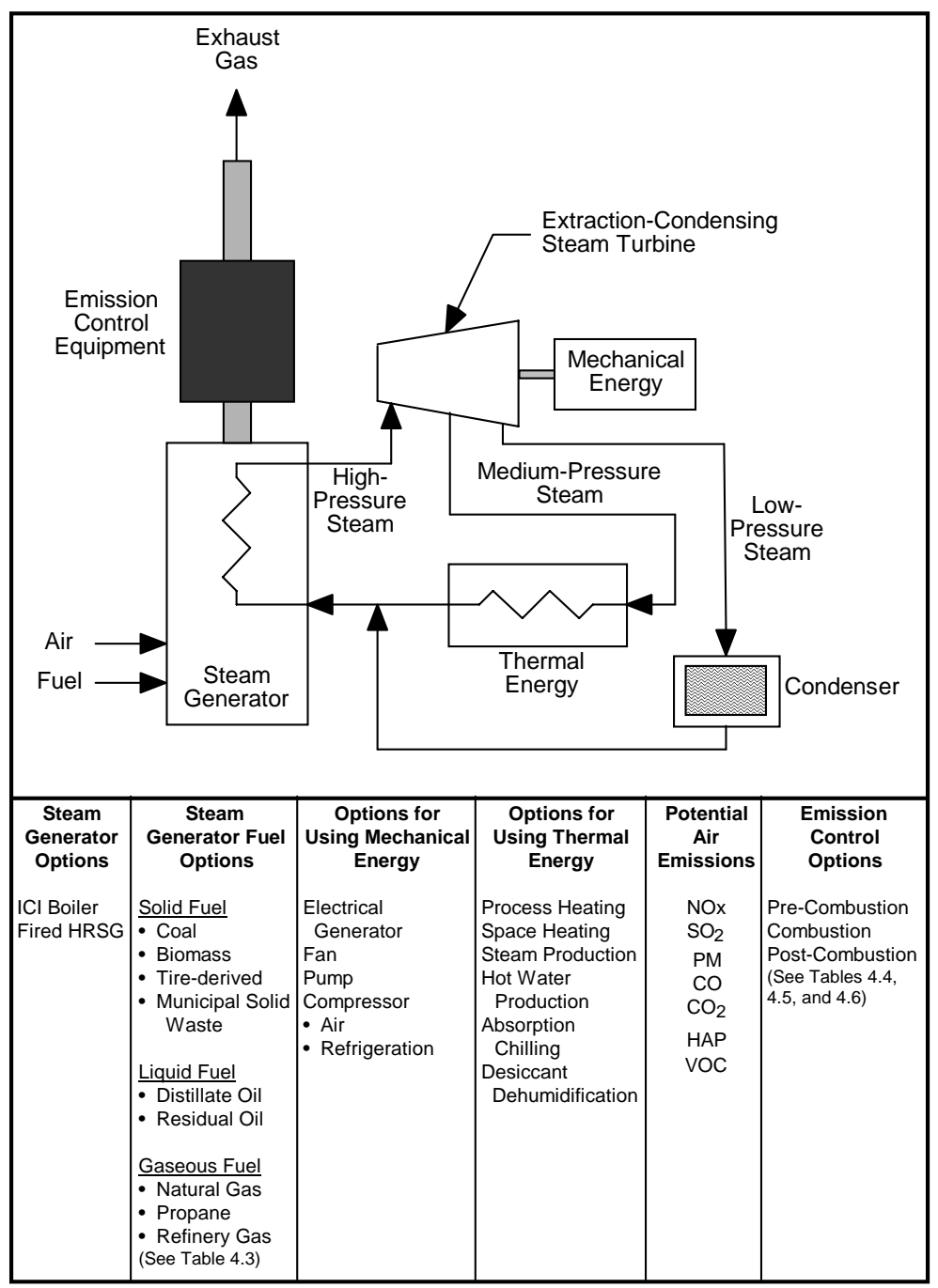

Fig. 8.2. Extraction-condensing steam turbine toppingcycle CHP system options. 


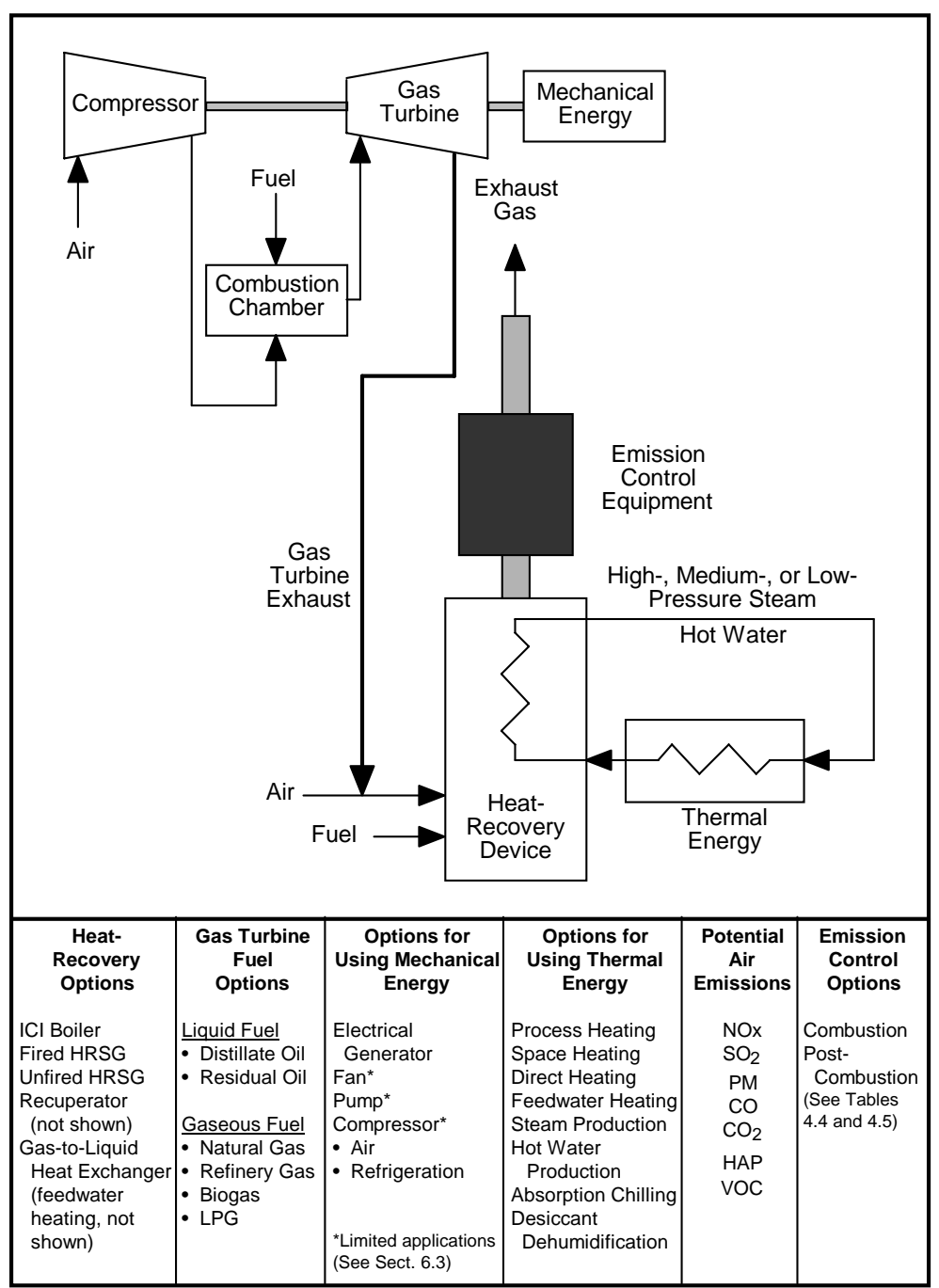

Fig. 8.3. Open-cycle gas turbine topping-cycle CHP system (without recuperator) options. 


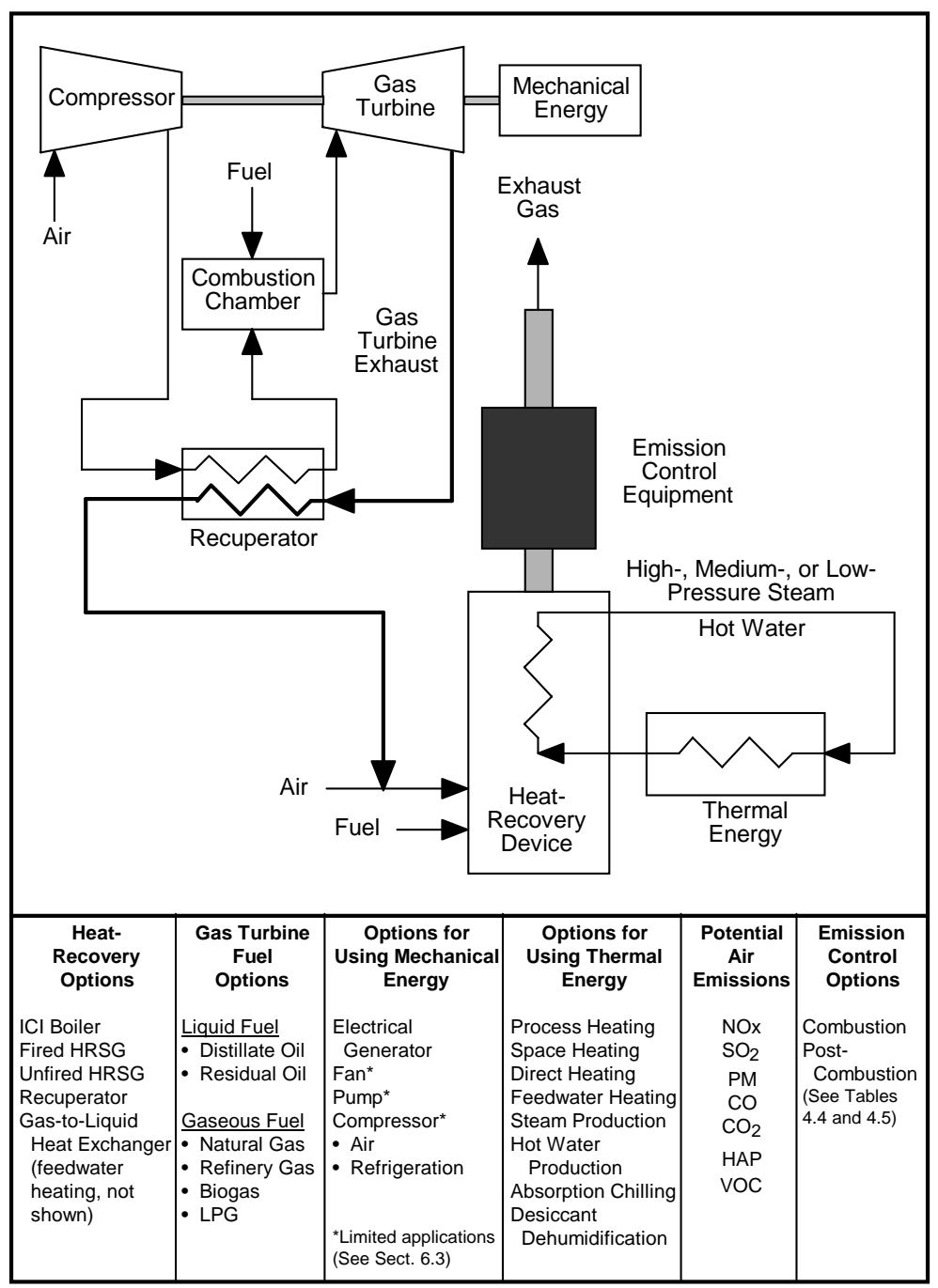

Fig. 8.4. Open-cycle gas turbine topping-cycle CHP system (with recuperator) options. 


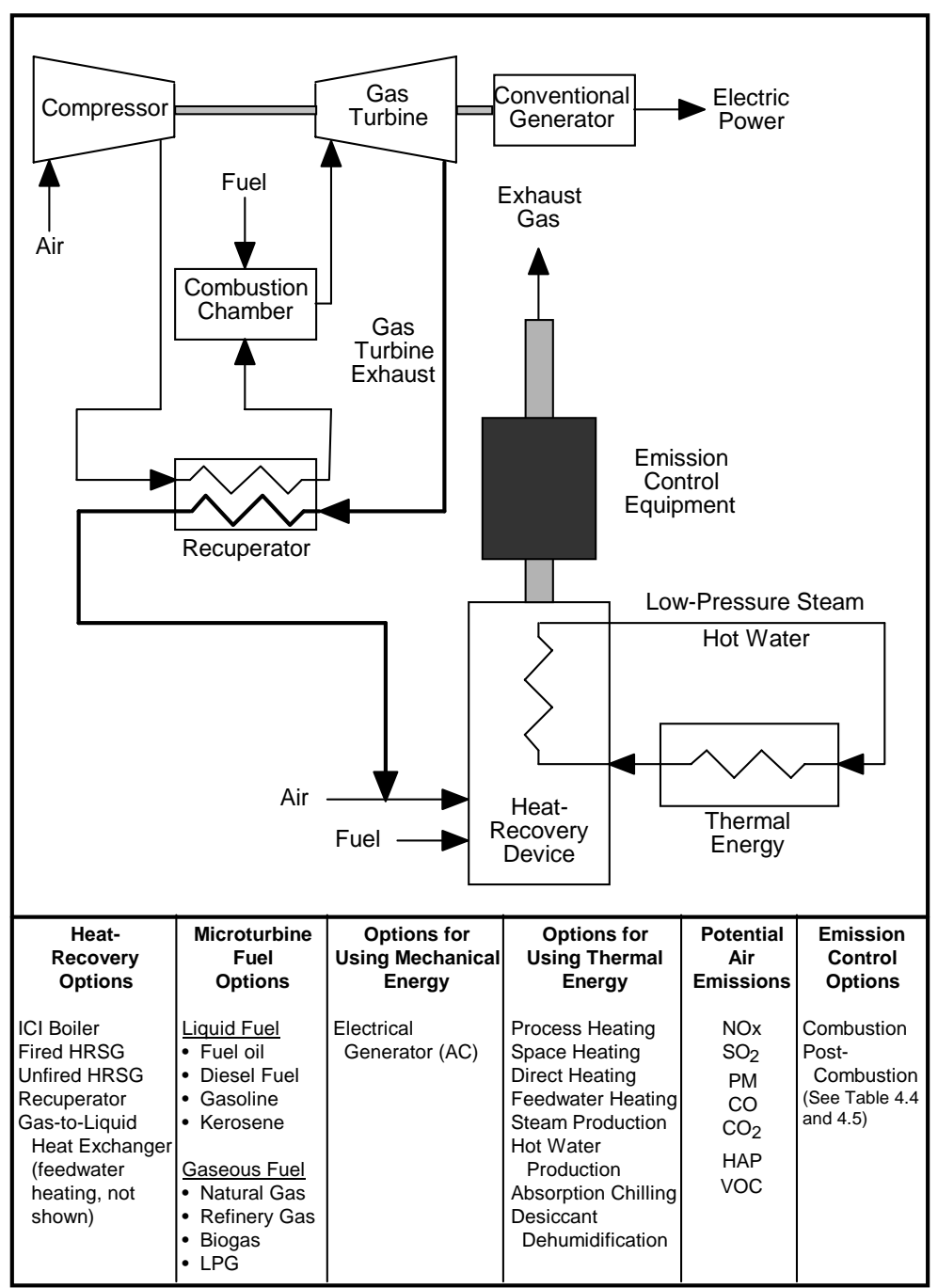

Fig. 8.5. Microturbine topping-cycle CHP system (with conventional generator) options. 


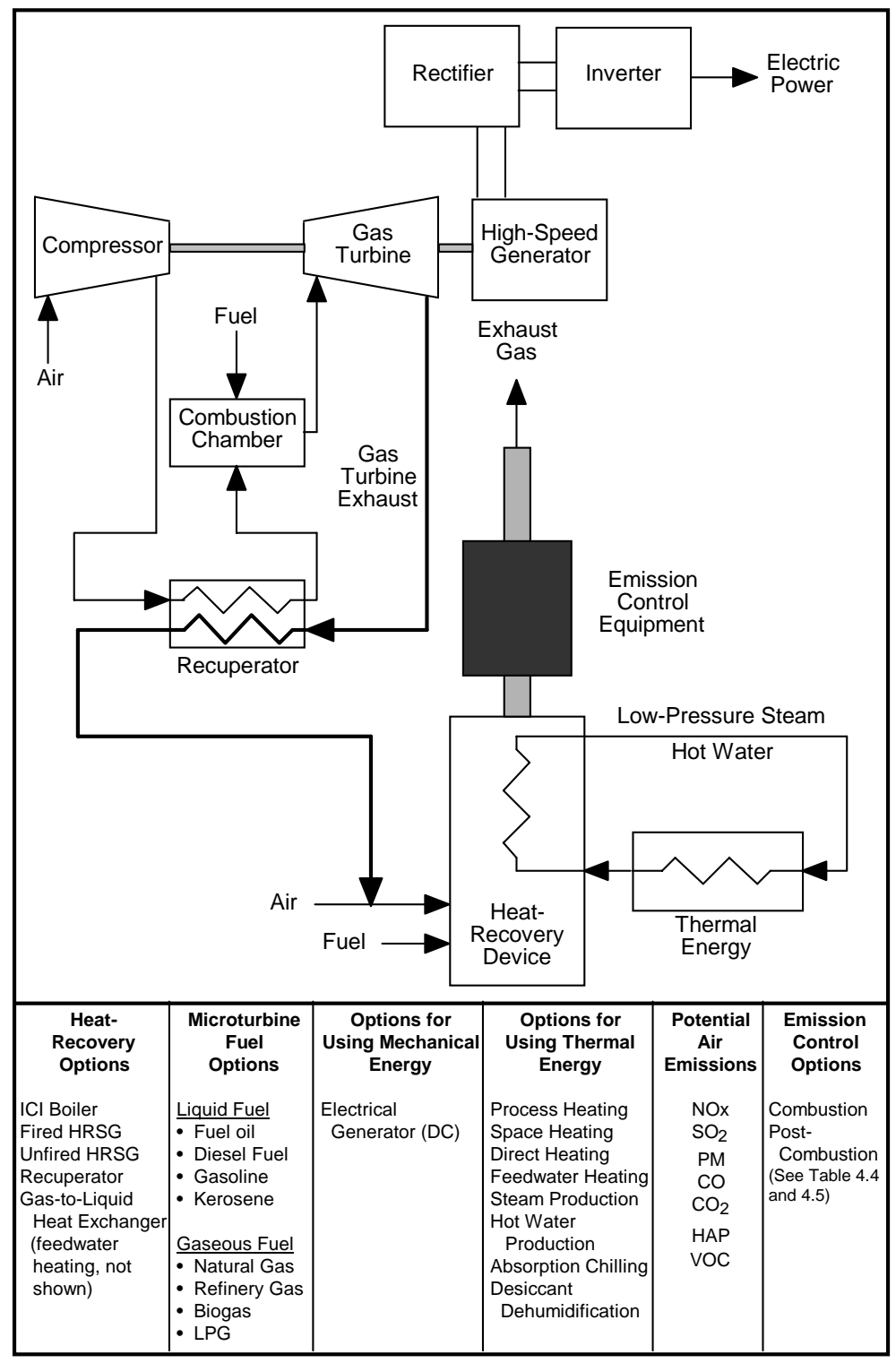

Fig. 8.6. Microturbine topping-cycle CHP system (with high-speed generator) options. 


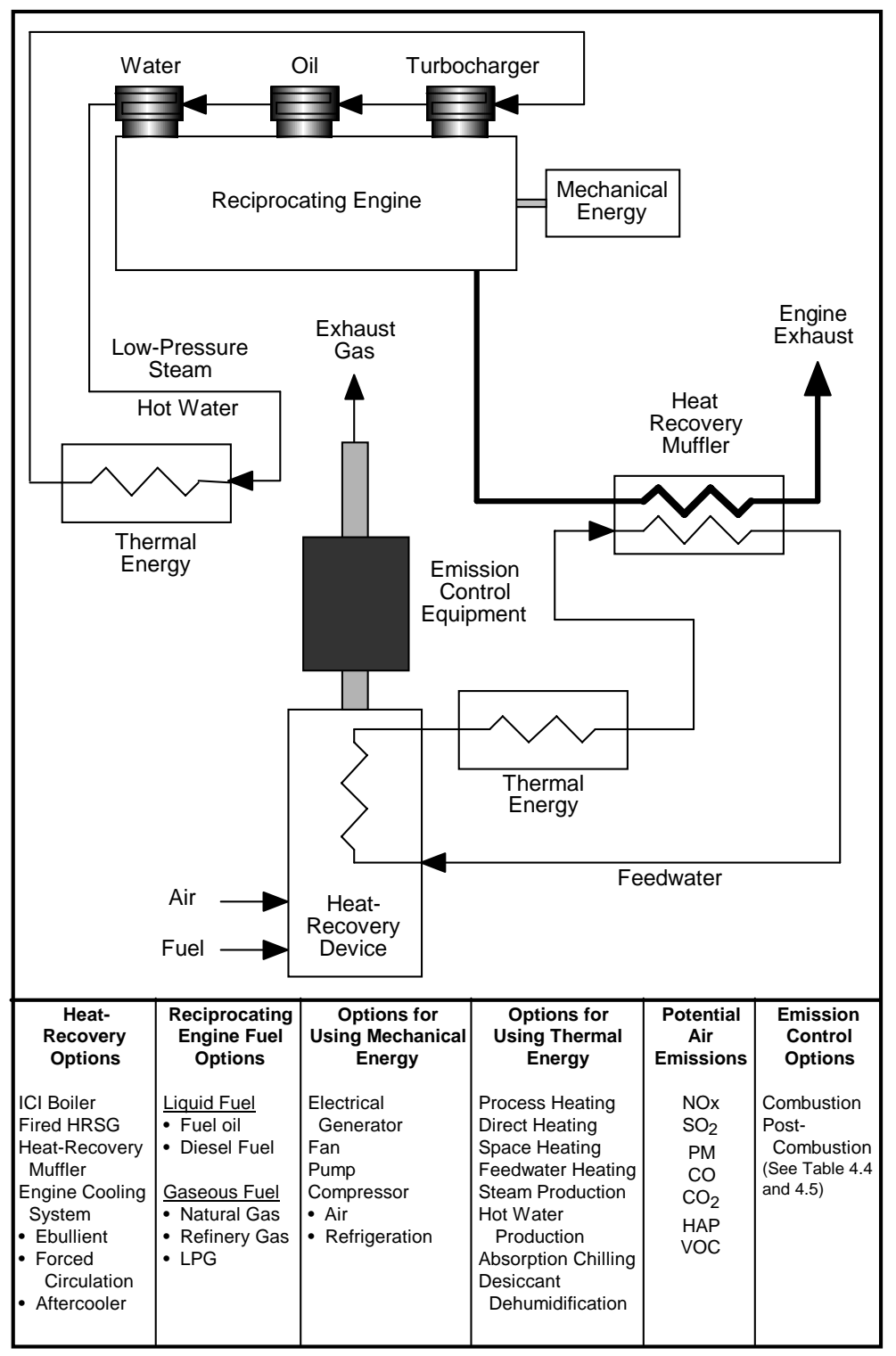

Fig. 8.7. Reciprocating engine topping-cycle CHP system options. 


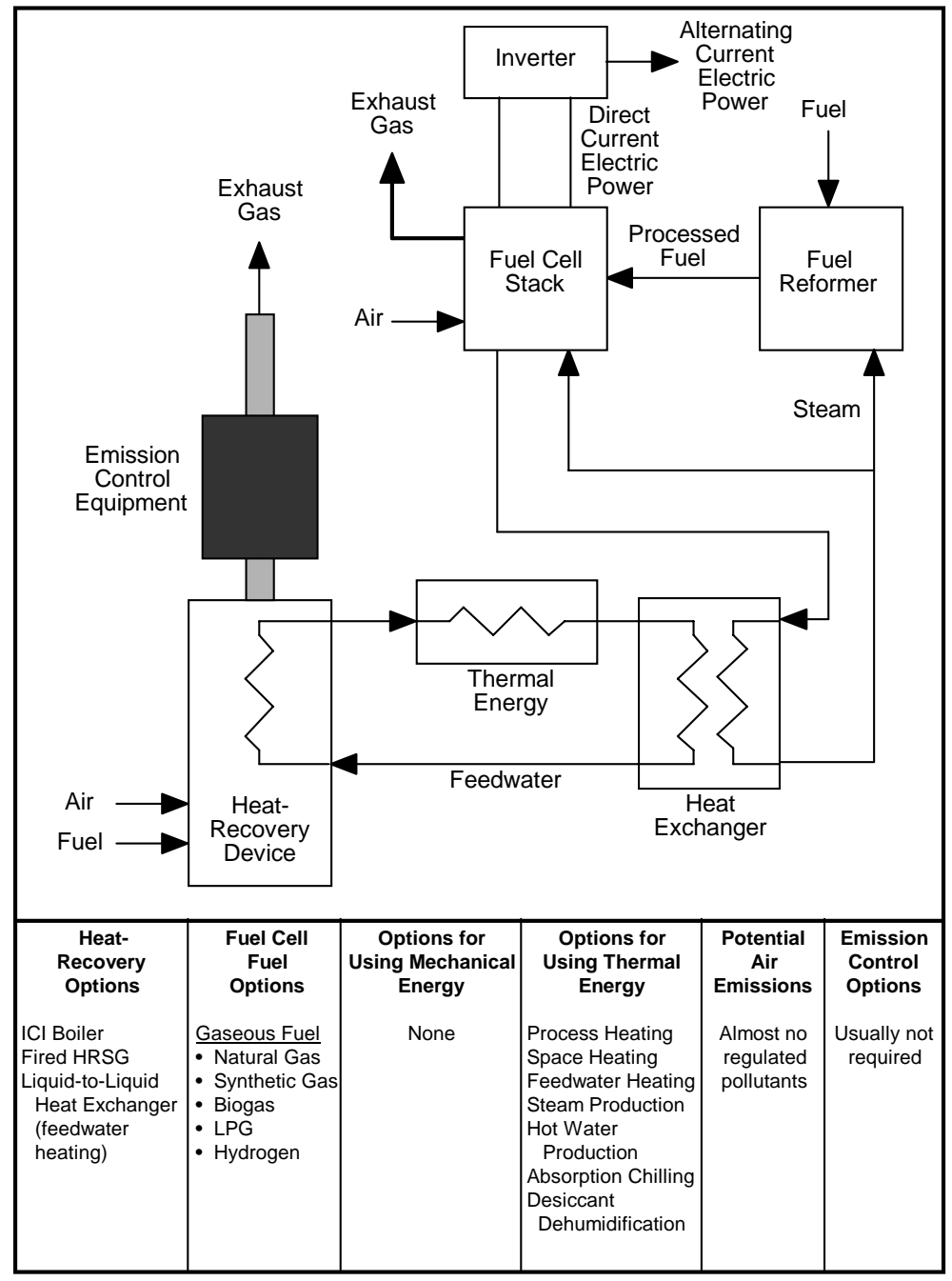

Fig. 8.8. Fuel cell topping-cycle CHP system options. 


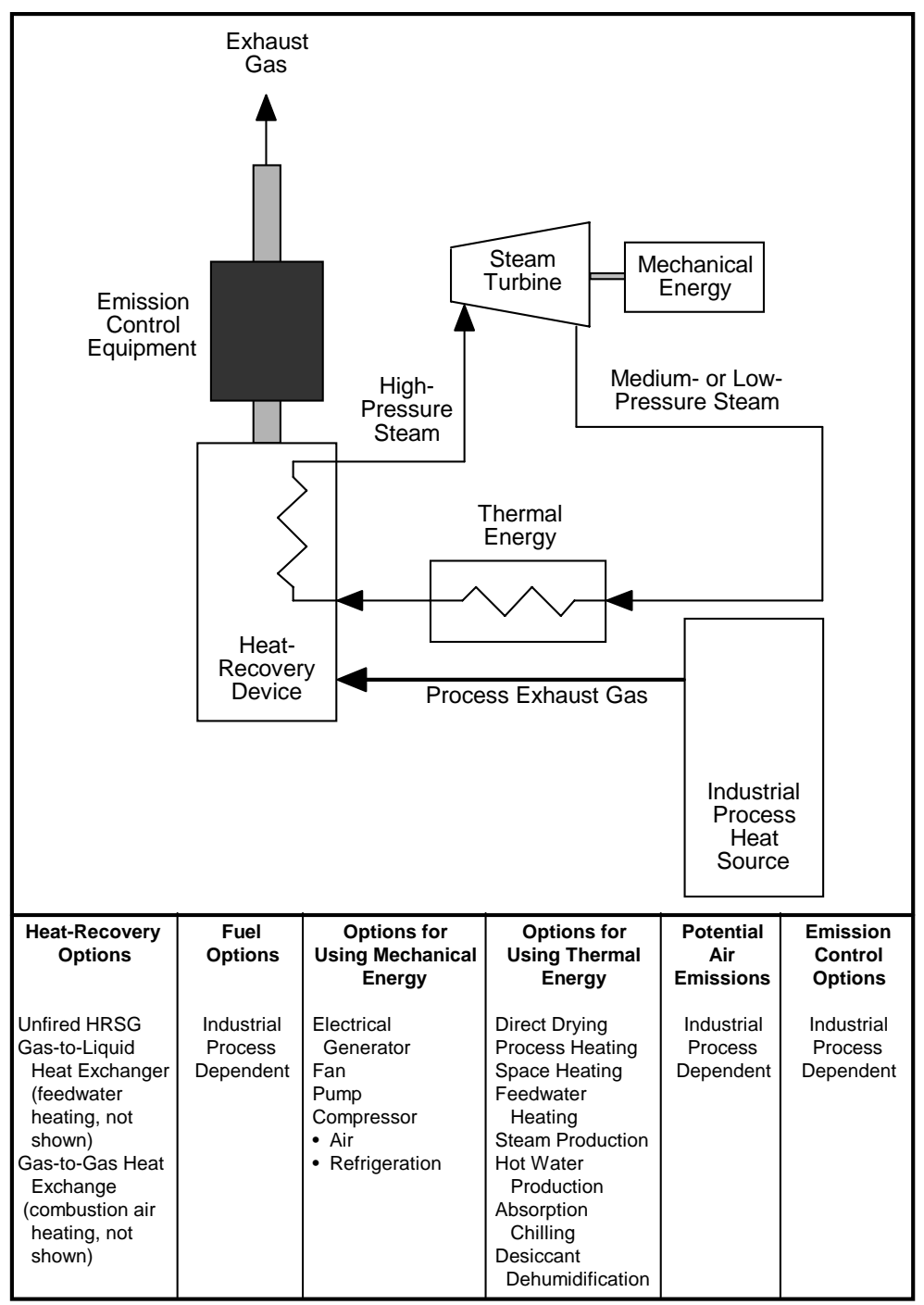

Fig. 8.9. Bottoming-cycle CHP system options. 


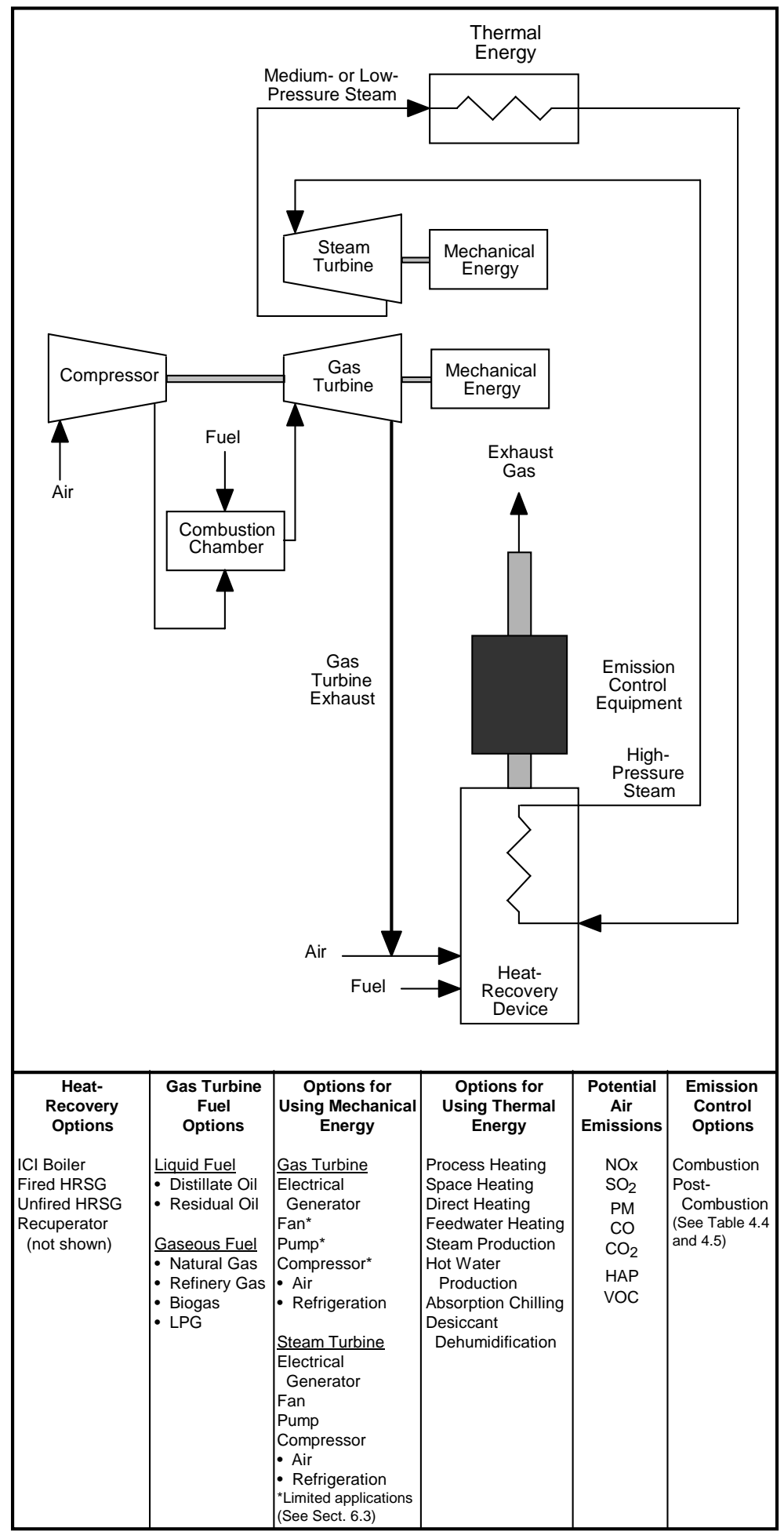

Fig. 8.10. Combined-cycle CHP system options. 


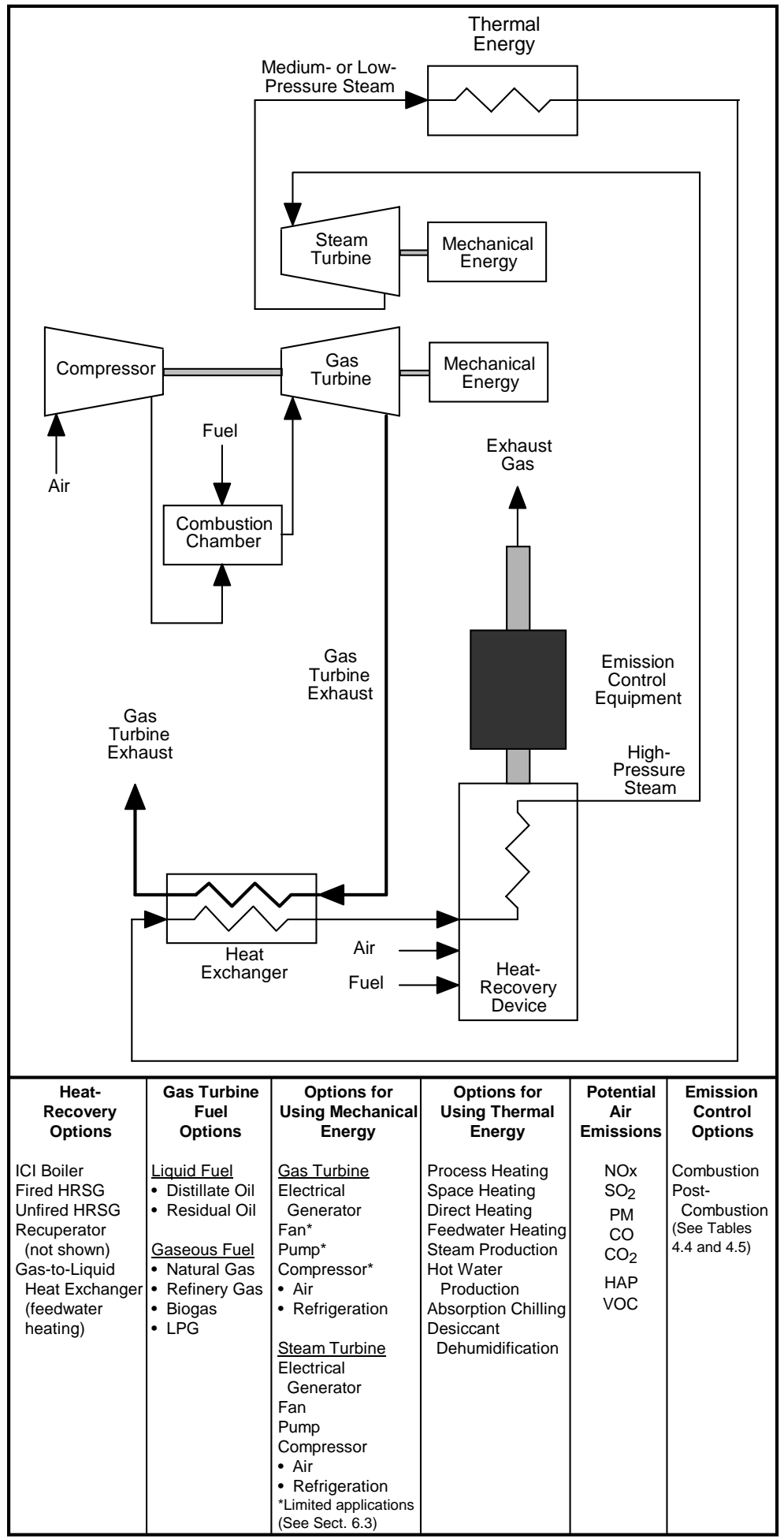

Fig. 8.11. Combined-cycle CHP system (with feedwater heating) options. 


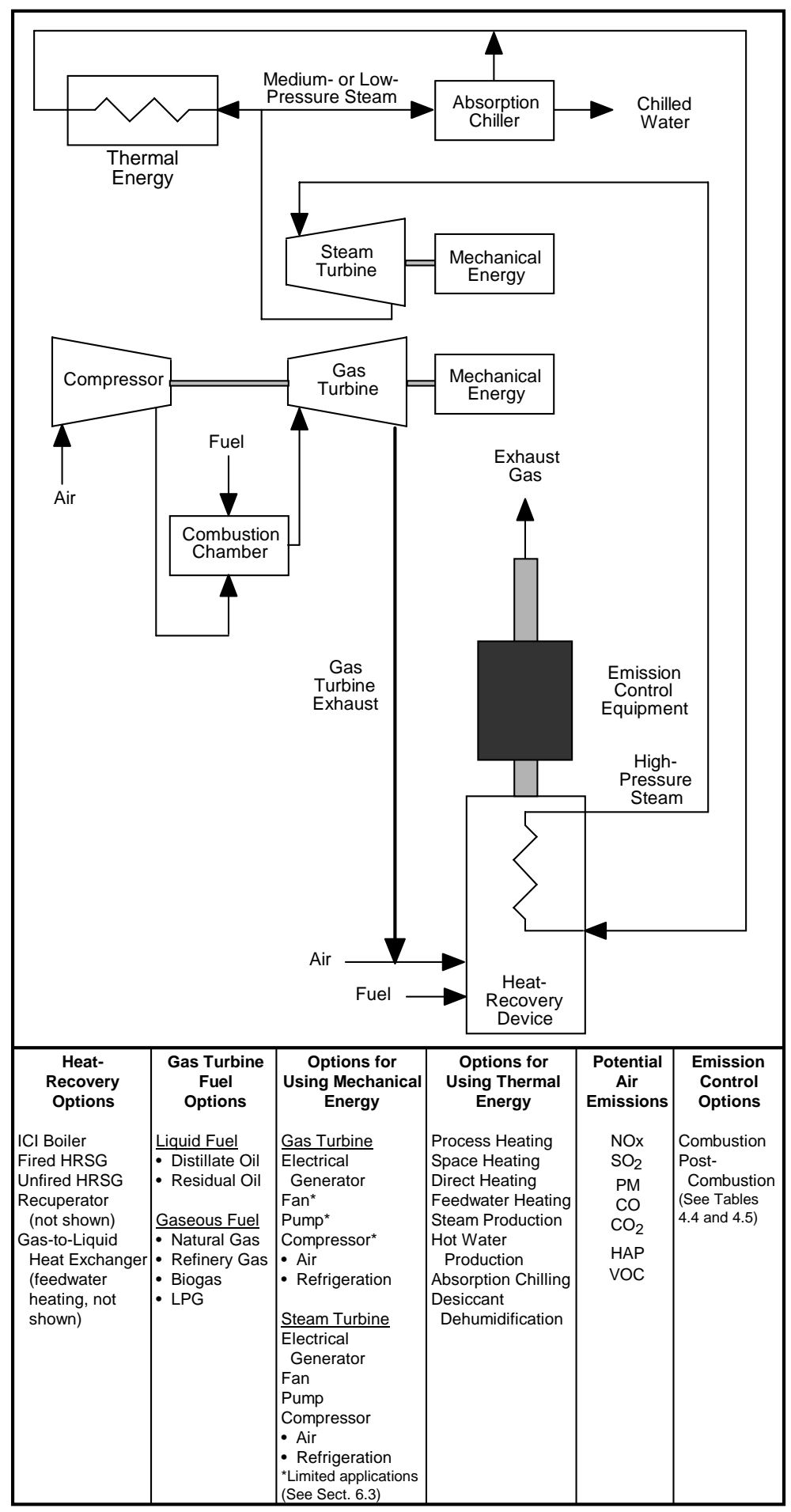

Fig. 8.12. Trigeneration CHP system options. Source: Ref. 1. 


\subsection{REFERENCES}

1. "Cogeneration Systems and Engine and Turbine Drives," Chapter 7, ASHRAE Handbook—HVAC Systems and Equipment, American Society of Heating, Refrigerating and Air-Conditioning Engineers, Inc., Atlanta, Georgia, July 6, 2000.

2. N. Petchers, Combined Heating, Cooling and Power Handbook: Technologies and Applications, The Fairmont Press, Inc., Lilburn, Georgia, 2003.

3. J. A. Orlando, Cogeneration Design Guide, American Society of Heating, Refrigerating and AirConditioning Engineers, Inc., Atlanta, Georgia, 1996.

4. Combined Heat and Power (CHP) Resources Guide, Midwest CHP Application Center, University of Illinois at Chicago, September 2003. 


\section{FEASIBILITY EVALUATION}

Integrating cogeneration technology into a new or existing ICI boiler installation has the potential to save fuel resources. However, there is no assurance of economic benefits due to factors such as the varying nature of fuel and electricity prices, financial environments, and regulatory requirements that are beyond the control of boiler owners and operators. Sites with reasonably high electrical load factors, high annual operating hours, and fairly constant and matching electrical and thermal energy demand profiles represent good candidates for CHP projects with above average potential for economic success. Installations with either low electricity rates or high CHP fuel costs generally have higher than average financial risk. To help assure positive economic benefits, CHP projects need to incorporate technical features that are optimized to meet both heat and power demands of the site. Developing an optimal solution requires knowledge of the site energy requirements and an understanding of the various CHP options that are capable of satisfying these requirements.

Cogeneration projects are generally characterized as viable when the different forms of energy produced on site have a higher value than the investment and operating costs incurred by the facility. Determining whether a CHP project is viable involves consideration of complex and interrelated issues. Because the cost of CHP fuel can be as much as $60 \%$ to $75 \%$ of the system's operating cost, ${ }^{1}$ the effects of fuel price fluctuations over the life of the project must not be ignored. In some cases, the revenue generated from the sale of excess electricity and heat or the cost of availing standby connection must also be taken into consideration. More difficult to quantify are the indirect benefits that may accrue from the CHP project, such as avoidance of economic losses associated with a disruption in the electrical grid and improvements in productivity and product quality. Key factors that should be considered when assessing CHP project economics include

- initial investment and cost of capital,

- operating and maintenance costs,

- purchase price of fuel and electricity, and

- $\quad$ sale price of electricity and heat sold off site, if applicable.

Although economic benefit is often the primary condition for project acceptance, other factors such as the reliability of the energy supply may be equally or more important. Some industrial processes are extremely sensitive to any disruption of energy supply that results in production losses. For these situations, the cost of generating electricity on site may be a secondary concern compared to maintaining production. Successful applications of industrial cogeneration technology generally involve

- maximizing the use of electricity generated on site,

- assuring continuous operation of the processes at nominal conditions, and

- avoiding the generation of excess thermal energy.

Many different approaches have been adopted for evaluating the viability of candidate CHP systems. ${ }^{2-5}$ These approaches attempt to formalize the complex evaluation process using a flow chart with criteria for making rational decisions about whether to implement cogeneration technology. The simple framework for evaluating the viability of a CHP project that is shown in Fig. 9.1 identifies some of the more important factors that ICI boiler owners and operators should consider when evaluating potential applications and benefits of cogeneration technology at their facilities. Key actions represented in this framework follow: 


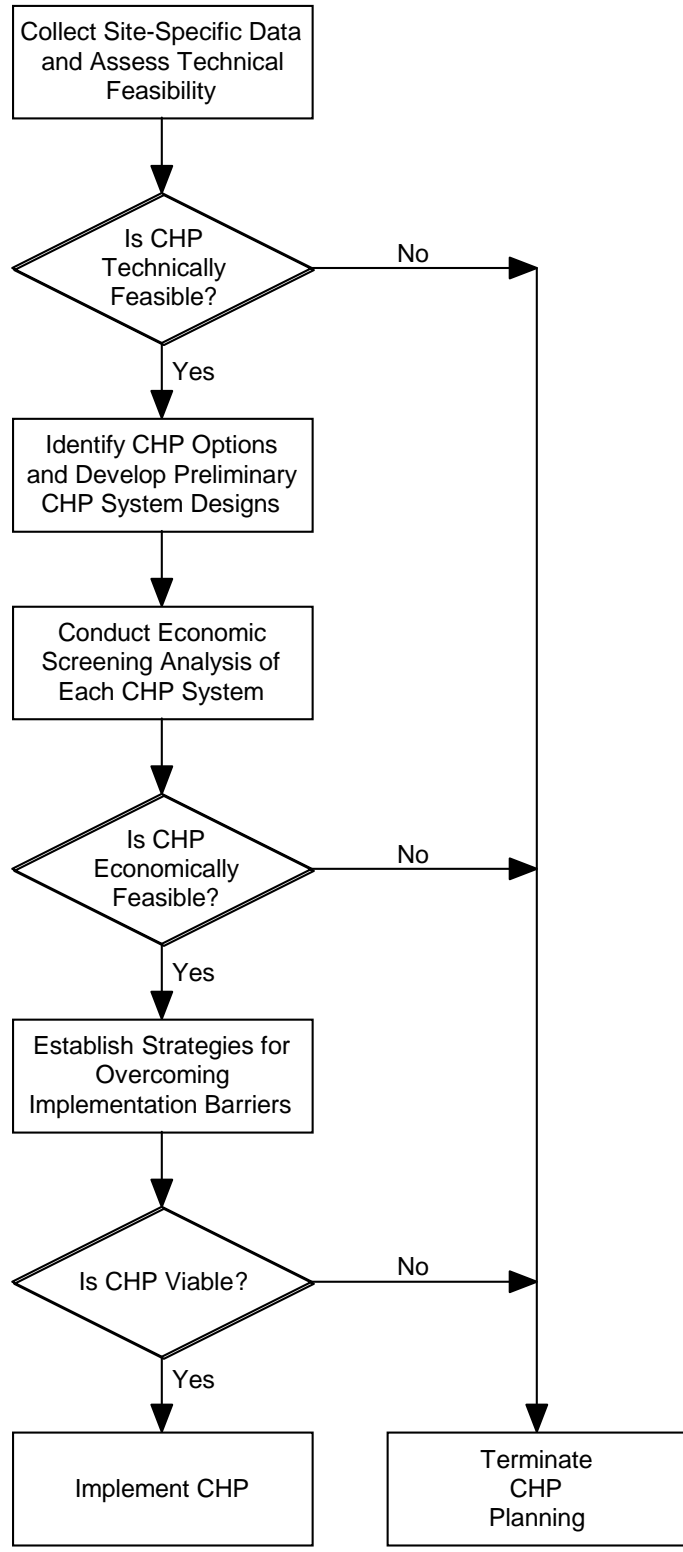

Fig. 9.1. Framework for evaluating the viability of a CHP project.

1. characterizing thermal and electrical energy demand patterns based on site-specific data,

2. determining if CHP is technically feasibility,

3. identifying different CHP options and developing preliminary CHP system designs,

4. conducting an economic screening analysis of each preliminary CHP system design,

5. selecting the preferred CHP system based on established financial and technical acceptance criteria, and

6. establishing strategies for overcoming barriers to implementation. 
Only when a CHP system is both technically and economically feasible and strategies for addressing implementation barriers are identified is there a need to proceed with project plans. ${ }^{6}$

\subsection{EVALUATING COGENERATION POTENTIAL}

Evaluating cogeneration potential is a multistage process that begins with an understanding of the infrastructure and operating requirements of the ICI boiler installation. Another strategic element is the identification of facility goals and objectives that can be used as screening criteria throughout the evaluation process. ${ }^{7}$ For some installations, the primary goal is to reduce the amount of purchased electricity and replace it with lower cost electricity generated on site. This may involve either

- generating some of the electricity needed at the site and purchasing the remainder from the local utility or another power provider, or

- generating all of the electricity needed at the site and making the excess, if any, available to the electrical grid for resale.

If reliability is the most important objective, then critical loads or operating conditions must be identified, so sufficient on-site generating capacity can be available when needed. Establishing the project objectives helps focus the technical and economic evaluations on issues that are both relevant and important.

Because many decisions are required to evaluate the feasibility of cogeneration technology at a particular ICI boiler installation, it is important to keep in mind the diverse nature of the technical and economic issues that need to be considered in the decision-making process. In general, these issues focus on

- $\quad$ site-specific data collection including

$\checkmark$ identification of energy-saving opportunities

$\checkmark$ preliminary screening to identify candidate CHP systems with good potential for economic success

- preliminary designs for technically feasible CHP systems

- economic screening analysis to eliminate CHP systems that are not practical and to identify CHP systems worth further consideration

- health, safety, and environmental issues including

$\checkmark$ noise and vibration

$\checkmark$ engineering barriers and administrative controls

$\checkmark$ electrical hazards

$\checkmark$ emissions control

$\checkmark$ construction and operating permits

- interface considerations involving the electrical grid.

\subsubsection{Walk-Through and Data Collection}

In evaluating the feasibility of a CHP project at an existing ICI boiler installation, it is important to conduct a walk-through to collect site-specific data about the facility and its energy requirements. ${ }^{2,3}$ Objectives of the walk-through and data collection effort are to acquire sufficient information to determine whether cogeneration is both technically and economically feasible. ${ }^{6}$ Types of information that may be useful include 
- space availability and infrastructure compatibility,

- power-to-heat ratio,

- required quality of thermal energy,

- electrical and thermal energy demand patterns,

- fuel price and availability,

- required system reliability,

- applicable environmental regulations and permitting requirements,

- dependability of the electrical grid,

- options for selling excess electricity, steam, or hot water to the local utility or a third party, and

- acceptable payback period.

For new installations, it is important for boiler owners and operators to be involved in identifying $\mathrm{CHP}$ options and alternatives at an early stage in the planning process. Much of the information needed for existing installations is also required to determine whether cogeneration is technically and economically feasible for new installations.

Because there is no assurance that a CHP project will produce economic benefits, walk-through and data collection activities should be completed without spending a significant amount of time or money. Useful resources such as the example data collection sheet shown in Fig. 9.2 and a walk-through checklist developed by the Midwest CHP Application Center (www.chpcentermw.org) are available to simplify the task of surveying the site and collecting relevant data. ${ }^{5}$

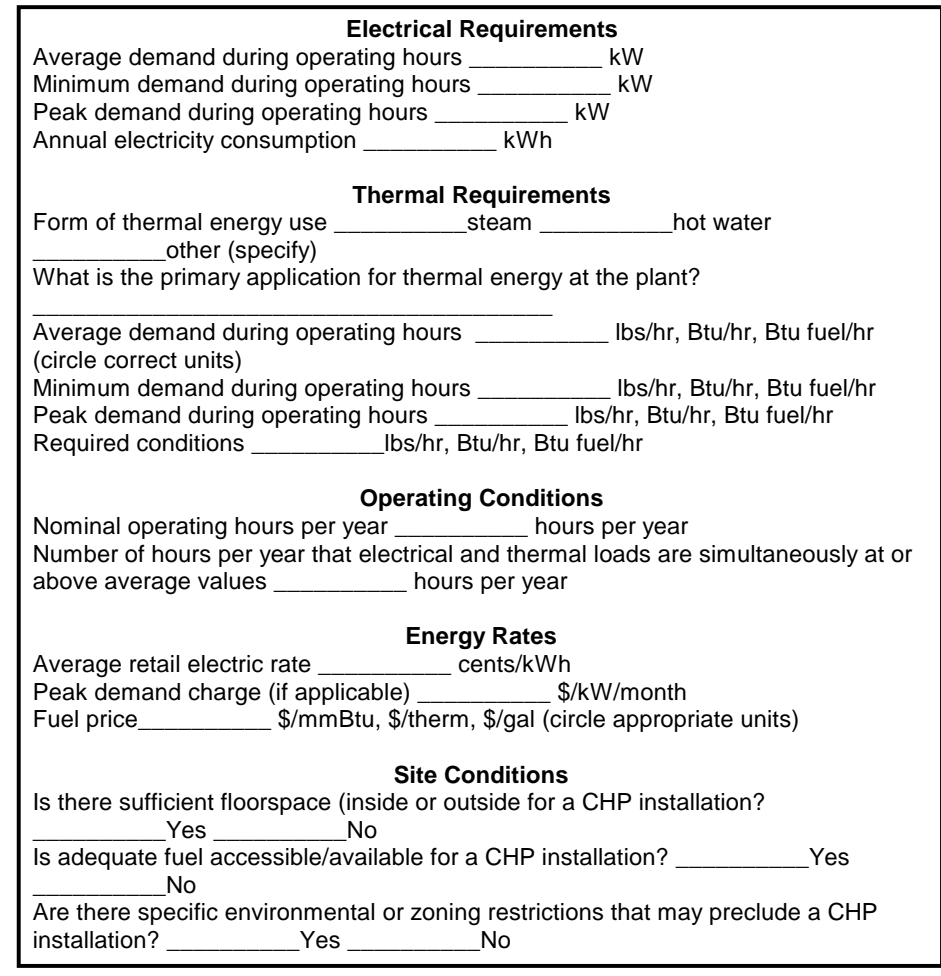

Fig. 9.2. Example data collection sheet. 


\subsubsection{Energy savings opportunities}

The walk-through and data collection phase of the feasibility evaluation is an ideal time to perform a site energy audit. Its purpose is to identify non-CHP energy-efficiency measures with potential for reducing electricity and fuel consumption. If thermal and electrical energy consumption can be reduced through other energy-efficiency measures, then a smaller CHP system may be appropriate. ${ }^{8}$ Although a smaller CHP system will likely cost less, the benefits may not be especially significant because economies of scale may be lost.

Energy-efficiency measures such as turning off equipment and lights that are not being used, setting back thermostats during nights and weekends, and informing employees about energy awareness represent simple, no-cost methods for reducing energy consumption. Other methods, like insulating steam and chilled water pipes, cleaning heat transfer surfaces, and replacing defective steam traps, generally have payback periods of 1 year or less. In many industrial facilities, it is often possible through system improvements and new technologies to reduce the amount of energy consumed by compressed air, pump, motor, steam, and process heating systems. Energy savings realized by implementing system improvements and new technology projects are often cost-effective, and the payback period for many of these projects is 2 years or less.

The DOE Industrial Technologies Program (ITP) has developed a variety of resources to help address industrial energy management needs (www.oit.doe.gov/bestpractices/pubs.shtml). Software tools and databases are available for conducting self-assessments of insulation, steam, compressed air, motor, pump, and process heating systems. These software tools, which are described in Table 9.1, are being used by all types of industries to identify energy savings opportunities. Publications, in the form of tip sheets, that may be useful in identifying ways to reduce energy consumption are also available. A compilation of tip sheet titles and energy saving opportunities is presented in Table 9.2. Systemwide and component-specific training sessions are also offered to help make the self-assessment process more effective (www.oit.doe.gov/bestpractices/training/). Information about specific energysavings opportunities is documented in case studies for many types of industrial facilities (www.oit.doe.gov/bestpractices/case_studies.shtml). To help promote energy efficiency, ITP issues Energy Matters, a quarterly newsletter that is a resource for news, technical tips, and case studies (www.oit.doe.gov/bestpractices/energymatters/energy_matters.shtml).

\subsubsection{Preliminary screening}

Before proceeding with the feasibility evaluation, it is important to understand how fuel and electricity prices can affect CHP economics. As discussed in Sect. 2.1, a CHP system is generally not economically viable unless the cost of generating electricity on site is less than the cost of purchasing electricity from the local utility. A number of screening tools have been developed specifically to help identify candidate CHP systems with good potential for economic success.

The CHP Walk-through Payback Estimator is a simple tool for quickly assessing the economic potential of natural-gas and oil-fired CHP systems. Analysis can be performed on-line at www.ornl.gov/cgi-bin/cgiwrap?user=chpcalc\&script=CHP_payback.cgi. After entering the average price of electricity, the average price of fuel (natural gas or oil), the number of operating hours, and the estimated unit cost of the installed CHP system, the software calculates annual cost savings and simple payback.

Sample results obtained using this software are presented in Tables 8.2-8.5 for CHP systems that operate for $8,000 \mathrm{~h} /$ year with an installed cost of either $\$ 500$ or $\$ 2,000 / \mathrm{kW}$. Similar parametric studies performed using the CHP Walk-through Payback Estimator can also be performed to characterize the economic significance of fuel and electricity price variations. Although meaningful results can be 
Table 9.1. Software for identifying energy savings opportunities

\begin{tabular}{|c|c|}
\hline Energy savings opportunity & Software $^{a}$ \\
\hline Calculate the economic thickness of thermal insulation & 3E Plus ${ }^{\circledR}$, Version 3.2 \\
\hline Assess the efficiency of pumping system operations & Pumping System Assessment Tool (PSAT) \\
\hline Select energy-efficient motors & MotorMaster+ 4.0 \\
\hline Assess compressed air systems & AIRMaster+ 1.0.9 \\
\hline $\begin{array}{l}\text { Determine the economic feasibility of an adjustable-speed } \\
\text { drive application }\end{array}$ & ASDMaster \\
\hline $\begin{array}{l}\text { Profile and grade steam system operations and management. } \\
\text { This spreadsheet tool will assist you in evaluating your steam } \\
\text { system operations against identified best practices }\end{array}$ & Steam System Scoping Tool, 1.0d \\
\hline $\begin{array}{l}\text { Assess potential savings from individualized steam-system } \\
\text { improvements. This software uses input data about a plant's } \\
\text { conditions to generate results detailing the energy, cost, and } \\
\text { emissions savings that various improvements could achieve }\end{array}$ & Steam System Assessment Tool (SSAT 1.0.0) \\
\hline $\begin{array}{l}\text { Survey all process heating equipment within a facility, select } \\
\text { the equipment that uses the most energy, and identify ways } \\
\text { to increase efficiency. This software can also be used to } \\
\text { assess equipment performance under various operating } \\
\text { conditions and "what-if " scenarios }\end{array}$ & $\begin{array}{l}\text { Process Heating Assessment and Survey Tool } \\
\text { (PHAST 1.1.1) }\end{array}$ \\
\hline $\begin{array}{l}\text { Assist plants in the petroleum refining and chemical industries } \\
\text { assess and analyze } \mathrm{NO}_{\mathrm{x}} \text { emissions and application of energy } \\
\text { efficiency improvements. The tool can be used to inventory } \\
\text { emissions from equipment that generates } \mathrm{NO}_{\mathrm{x}} \text {, and then } \\
\text { compare how various technology applications and efficiency } \\
\text { measure affect overall costs and reduction of } \mathrm{NO}_{\mathrm{x}} \text {. This } \\
\text { software also performs "what-if" analyses to optimize and } \\
\text { select the most cost-effective methods for reducing } \mathrm{NO}_{\mathrm{x}} \\
\text { from systems such as fired heaters, boilers, gas turbines, and } \\
\text { reciprocating engines }\end{array}$ & $\begin{array}{l}\mathrm{NO}_{\mathrm{x}} \text { and Energy Assessment Tool (NxEAT) } \\
\text { (www.oit.doe.gov/bestpractices/steam/neat.html) }\end{array}$ \\
\hline
\end{tabular}

a"Decision Tools for Industry," DOE/GO-102003-1719, U.S. Department of Energy, March 2003, available from http://www.oit.doe.gov/bestpractices/software_tools.shtml or OIT Clearinghouse, phone: (800) 586-2086, email: clearinghouse@ee.doe.gov 
Table 9.2. Tips for identifying energy savings opportunities

\begin{tabular}{|c|c|}
\hline Energy savings opportunity & Reference document ${ }^{a}$ \\
\hline $\begin{array}{l}\text { Operate boilers at or near design } \\
\text { capacity }\end{array}$ & $\begin{array}{l}\text { Benchmark the Fuel Cost of Steam Generations, Steam Tip Sheet 15, } \\
\text { DOE/GO-102000-1115, December 2000, USDOE } \\
\text { Minimize Boiler Short Cycling Losses, Steam Tip Sheet 16, } \\
\text { DOE/GO-102000-1116, December 2000, USDOE } \\
\text { Improve Your Boiler's Combustion Efficiency, Process Heat Tip Sheet 4, } \\
\text { DOE/GO-102002-1506, March 2002, USDOE } \\
\text { Preheated Combustion Air, Process Heat Tip Sheet 1, } \\
\text { DOE/GO-102002-1551, May 2002, USDOE }\end{array}$ \\
\hline Reduce excess air & $\begin{array}{l}\text { Check Burner Air to Fuel Ratios, Process Heat Tip Sheet 2, } \\
\text { DOE/GO-102002-1552, May 2002, USDOE }\end{array}$ \\
\hline Clean heat transfer surfaces & $\begin{array}{l}\text { Clean Boiler Water-side Heat Transfer Surfaces, Steam Tip Sheet 7, } \\
\text { DOE/GO-10099-952, June 2001, USDOE }\end{array}$ \\
\hline Reduce heat loss from openings & $\begin{array}{l}\text { Cover Heated Open Vessels, Steam Tip Sheet 3, DOE/GO-102002-1477, } \\
\text { January 2002, USDOE }\end{array}$ \\
\hline $\begin{array}{l}\text { Reduce heat loss by installing } \\
\text { thermal insulation }\end{array}$ & $\begin{array}{l}\text { Insulate Steam Distribution and Condensate Return Lines, Steam Tip } \\
\text { Sheet 2, DOE/GO-102002-1504, March 2002, USDOE } \\
\text { Install Removable Insulation on Uninsulated Valves and Fittings, Steam Tip } \\
\text { Sheet 17, DOE/GO-102000-1117, December 2000, USDOE }\end{array}$ \\
\hline Install heat-recovery equipment & $\begin{array}{l}\text { Use Feedwater Economizers for Waste Heat Recovery, Steam Tip Sheet } 3 \text {, } \\
\text { DOE/GO-102002-1505, March 2002, USDOE } \\
\text { Use Vapor Recompression to Recover Low-Pressure Waste Steam, Steam } \\
\text { Tip Sheet 11, DOE/GO-102001-1274, May 2001, USDOE } \\
\text { Recover Heat from Boiler Blowdown, Steam Tip Sheet 10, } \\
\text { DOE/GO-10099-955, Revised June 2001, USDOE }\end{array}$ \\
\hline $\begin{array}{l}\text { Improve water treatment to } \\
\text { minimize boiler blowdown }\end{array}$ & $\begin{array}{l}\text { Minimize Boiler Blowdown, Steam Tip Sheet 9, DOE/GO-10099-954, } \\
\text { Revised June 2001, USDOE }\end{array}$ \\
\hline Optimize deaerator vent rate & $\begin{array}{l}\text { Deaerator in Industrial Steam Systems, Steam Tip Sheet 18, } \\
\text { DOE/GO-102000-1118, December 2000, USDOE }\end{array}$ \\
\hline Repair steam leaks & $\begin{array}{l}\text { Inspect and Repair Steam Traps, Steam Tip Sheet 1, } \\
\text { DOE/GO-102002-1503, March 2002, USDOE }\end{array}$ \\
\hline Minimize vented steam & $\begin{array}{l}\text { Use a Vent Condenser to Recover Flash Steam Energy, Steam Tip Sheet 13, } \\
\text { DOE/GO-102001-1276, May 2001, USDOE }\end{array}$ \\
\hline $\begin{array}{l}\text { Use high-pressure condensate to } \\
\text { generate low-pressure steam }\end{array}$ & $\begin{array}{l}\text { Flash High-Pressure Condensate to Regenerate Low-Pressure Steam, Steam } \\
\text { Tip Sheet 12, DOE/GO-102001-1275, May 2001, USDOE }\end{array}$ \\
\hline $\begin{array}{l}\text { Use back-pressure steam turbines } \\
\text { instead of pressure-reducing } \\
\text { valves }\end{array}$ & $\begin{array}{l}\text { Replace Pressure-Reducing Valves with Backpressure Turbogenerators, } \\
\text { Steam Tip Sheet 20, DOE/GO-102002-1476, December 2002, USDOE }\end{array}$ \\
\hline Optimize condensate recovery & $\begin{array}{l}\text { Return Condensate to the Boiler, Steam Tip Sheet 8, DOE/GO-10099-953, } \\
\text { Revised June 2001, USDOE }\end{array}$ \\
\hline $\begin{array}{l}\text { Use steam to power rotating } \\
\text { machinery }\end{array}$ & $\begin{array}{l}\text { Consider Steam Turbine Drives for Rotating Equipment, Steam Tip } \\
\text { Sheet 21, DOE/GO-102002-1475, January 2002, USDOE }\end{array}$ \\
\hline $\begin{array}{l}\text { Use steam to produce a cooling } \\
\text { effect }\end{array}$ & $\begin{array}{l}\text { Use Low Grade Waste Steam to Power Absorption Chillers, Steam Tip } \\
\text { Sheet 14, DOE/GO-102001-1277, May 2001, USDOE }\end{array}$ \\
\hline
\end{tabular}

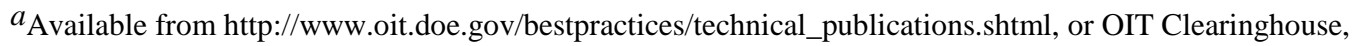
phone: (800) 586-2086, email: clearinghouse@ee.doe.gov 
obtained using the tool, final decisions about the economic viability of CHP projects should not be based solely on CHP Walk-through Payback Estimator output because it has recognized limitations. For example, fundamental assumptions built into the analysis suggest that the cost of electricity and fuel always remain constant, and all of the electricity and thermal energy produced by the CHP system is used productively. Other variables such as tariffs, maintenance and operating costs, fluctuations in thermal and electricity demand, interest charges, and many other important parameters are not accurately modeled in the analysis. When used as intended, the CHP Walk-through Payback Estimator can help boiler owners and operators screen candidate CHP systems to identify those with little or no chance of financial success. As the data in Tables 8.2-8.5 show, it is possible for certain fuel and electricity cost combinations to produce no cost savings. In these situations, cogeneration is unlikely to be an economical option and consideration should be given to terminating CHP project planning activities.

Another screening assessment tool for natural-gas-powered CHP systems can be downloaded from the Midwest CHP Applications Center website (www.chpcentermw.org/10-00_tools.html) The tool, which is known as the Spreadsheet for Evaluating Economics of CHP Systems, identifies CHP systems with favorable economic potential by examining the cost differential between electricity and natural gas. After entering required site-specific data, the tool estimates rough savings, installation cost, and payback. ${ }^{5}$ Although more input is required compared to the CHP Walk-through Payback Estimator, it is important to understand that the output from both of these screening tools should not be used to make final decisions about the economic viability of a CHP system.

The BCHP Screening Tool, Version 1.1, was developed by the DOE Office for Energy Efficiency and Renewable Energy for use in computing hourly building heating, ventilating, air conditioning, and electric loads. It also performs annual energy cost and CHP paybacks by using equipment and electricity rate databases for 160 cities in the United States. The software is available on CD-ROM from the Cooling and Heating and Power Group of the Engineering Sciences and Technology Division of the ORNL.

A CHP investment appraisal spreadsheet that can be completed manually or using a computer is available from the British Department of the Environment, Transportation, and the Regions. It is used to perform preliminary appraisals of potential processes or sites for profitable adoption of cogeneration technology. Discussions about the tool and the underlying appraisal methodology are provided in a costfree publication that is available from the Energy Efficiency Enquiries Bureau, Oxfordshire, England. ${ }^{4}$ A completed example is included in the publication to help guide the user.

Software known as the Steam System Assessment Tool (SSAT) was developed by DOE for assessing potential savings from individualized steam-system improvements including the addition of one or more steam turbine topping-cycle CHP systems. Using site-specific input, the software generates results detailing potential energy, cost, and emissions savings that various improvements could achieve. The tool contains all the key features of typical steam systems, including boilers, back-pressure turbines, condensing turbines, deaerators, letdowns, flash vessels, and feedwater heat exchangers. Analytical results provide information about boiler efficiency, boiler blowdown, cogeneration, steam cost, condensate recovery, heat recovery, vent steam, insulation efficiency, alternative fuels, back-pressure steam turbines, steam traps, steam quality, and steam leaks.

The "Cogeneration Ready Reckoner" is a more comprehensive screening tool designed to assist with preliminary analysis of the technical and economic potential of cogeneration projects. Developed for the Australian Commonwealth Department of Industry, Tourism, and Resources, the software and user's manual $^{9}$ can be downloaded at no cost using a personal computer (www.ecogeneration.com.au/readyreckoner/ready.htm). Although originally intended primarily for use in Australia, the software was updated in 2002 to include U.S. currency and customary units of measure. More information about this tool and its capabilities is provided in Sect. 9.1.3.

Software tools available from governmental organizations and private businesses are presented in Table 9.3. Additional information about combined cooling, heating, and power technology is available from the Distributed Energy (DE) Program within the DOE (www.eere.energy.gov/de/). Established in 
FY 2001, this program is developing a portfolio of advanced on-site, small-scale, and modular energy conversion and delivery systems for industrial, commercial, residential, and utility applications. Program activities include

- distributed energy technology (activities in industrial gas turbines, microturbines, reciprocating engines, and thermally activated technologies);

- technology base efforts (long-term R\&D in the areas of materials, sensors, and power electronics); and

- $\quad$ systems integration [covering such technologies as packaged cooling, heating, and power (CHP) systems for end-use market].

Table 9.3. CHP software

\begin{tabular}{|c|c|c|c|}
\hline Software name & Primary application & Free & Reference \\
\hline $\begin{array}{c}\text { CHP Walk- } \\
\text { through } \\
\text { Payback } \\
\text { Estimator }\end{array}$ & $\begin{array}{l}\text { Natural-gas and oil- } \\
\text { powered CHP systems }\end{array}$ & Yes & $\begin{array}{l}\text { www.ornl.gov/cgi- } \\
\text { bin/cgiwrap?user=chpcalc\&script=CHP_payback.cgi }\end{array}$ \\
\hline $\begin{array}{l}\text { Spreadsheet for } \\
\text { Evaluating } \\
\text { Economics of } \\
\text { CHP Systems }\end{array}$ & $\begin{array}{l}\text { Natural-gas-powered } \\
\text { CHP systems }\end{array}$ & Yes & www.chpcentermw.org/10-00_tools.html \\
\hline $\begin{array}{l}\text { Cogeneration } \\
\text { Ready } \\
\text { Reckoner }\end{array}$ & Industrial CHP & Yes & www.ornl.gov/sci/eere/der/sia.htm \\
\hline $\begin{array}{l}\text { Combined Heat } \\
\text { and Power } \\
\text { (CHP) Tool }\end{array}$ & Industrial CHP & Yes & Under development by DOE \\
\hline CogenPro & $\begin{array}{l}\text { CHP sizing software for } \\
\text { federal facilities }\end{array}$ & Yes & www-rohan.sdsu.edu/ eadc/cogenH.html \\
\hline RECIPRO & $\begin{array}{l}\text { CHP using reciprocating } \\
\text { engines }\end{array}$ & No & $\begin{array}{l}\text { www.thermoflow.com/ } \\
\text { www.thermoflow.com/overview.htm }\end{array}$ \\
\hline PDE & $\begin{array}{l}\text { Industrial CHP using gas } \\
\text { turbines }\end{array}$ & No & $\begin{array}{l}\text { www.thermoflow.com/ } \\
\text { www.thermoflow.com/overview.htm }\end{array}$ \\
\hline $\begin{array}{l}\text { BCHP Screening } \\
\text { Tool }\end{array}$ & Building CHP systems & Yes & $\begin{array}{l}\text { Available from the Oak Ridge National Laboratory, } \\
\text { Email:fischersk@ ornl.gov }\end{array}$ \\
\hline $\begin{array}{l}\text { Building Energy } \\
\text { Analyzer }\end{array}$ & Building CHP systems & No & $\begin{array}{l}\text { www.interenergysoftware.com/ } \\
\text { www.interenergysoftware.com/BEA/BEAAbout.htm }\end{array}$ \\
\hline D-Gen Pro & Building CHP systems & No & www.archenergy.com/dgenpro/default \\
\hline HeatMap CHP & $\begin{array}{c}\text { Industrial CHP and } \\
\text { district energy }\end{array}$ & No & www.energy.wsu.edu/software/ \\
\hline GT Pro & $\begin{array}{l}\text { Industrial CHP using gas } \\
\text { turbines }\end{array}$ & No & $\begin{array}{l}\text { www.thermoflow.com/ } \\
\text { www.thermoflow.com/overview.htm }\end{array}$ \\
\hline SSAT & $\begin{array}{l}\text { Industry CHP using steam } \\
\text { turbines }\end{array}$ & Yes & www.oit.doe.gov/bestpractices/software_tools.shtml \\
\hline Steam Pro & $\begin{array}{l}\text { Conventional steam } \\
\text { power plants, with or } \\
\text { without cogeneration }\end{array}$ & No & $\begin{array}{l}\text { www.thermoflow.com/ } \\
\text { www.thermoflow.com/overview.htm }\end{array}$ \\
\hline SOAPP-CT.25 & $\begin{array}{l}\text { Industrial CHP using gas } \\
\text { turbines }\end{array}$ & No & www.soapp.com/soapp/dg/ \\
\hline
\end{tabular}


The combined heat and power area of the DE Program coordinates several CHP-related activities at DOE. Its objectives are to raise awareness of the energy, economic, and environmental benefits of CHP and to highlight barriers to increased implementation. The Web site for this program area (www.eere.energy.gov/de/program_areas/euid_combo_prgrm.shtml) includes information on CHP programs carried out by other DOE offices.

\subsubsection{Preliminary Design}

In order to identify the optimum CHP system for a particular site, it is important to establish preliminary designs for as many CHP configurations as possible. Each preliminary design needs to include one or more prime movers and appropriate heat-recovery equipment arranged into either a topping-cycle, bottoming-cycle, or combined-cycle configuration. Twelve different CHP systems that can serve as the basis for each preliminary design are described in Sect. 8.5. Initially, the most important design criteria should be to provide the required amounts of thermal and electrical energy for the site. Another important factor that needs to be considered at an early stage in the decision-making process involves selecting the appropriate number and size of redundant prime movers. The purpose for these prime movers is to provide the required level of thermal and electrical energy during both planned and forced outages. Issues such as the capacity and availability of alternative energy sources, impacts of reduced thermal and electrical energy on operations, and expected frequency and duration of planned and forced outages should not be overlooked. Designs for CHP systems that are not technically feasible, incompatible with the existing infrastructure, occupy too much space, or require fuel that is unavailable should not be considered.

Prime movers commonly selected for CHP systems in ICI boiler applications include steam and gas turbines, but microturbines, reciprocating engines, and fuel cells are also available. The required size and number of prime movers is a function of the electricity and thermal demand, fuel type and availability, mode of operation, and environmental factors like noise and emissions. Equally important is the selection of heat-recovery equipment suitable for recovering and using the waste heat. At existing ICI boiler installations, it is also important to verify that adequate space is available for the required components. Other factors that can influence the designs include zoning restrictions, environmental regulations, and building code requirements.

Once preliminary designs are developed, the process of evaluating the technical merits of each design can begin. Because many technical issues must be considered when evaluating CHP system feasibility, it is often necessary to assemble a multidisciplinary team of knowledgeable individuals with an understanding of complex mechanical and electrical systems technology. If the technical evaluation identifies one or more feasible preliminary designs, the next step in the decision-making process involves an evaluation of their economic feasibility.

\subsubsection{Economic Screening Analysis}

When preliminary design efforts result in a number of CHP systems that are technically feasible, an economic analysis of each design must be performed. The primary objectives of the screening exercise are to eliminate candidate CHP systems that are not practical and to identify the preferred CHP system for further consideration. Results of the economic screening analysis should provide boiler owners and operators with the fundamental information they need to justify a continuation of project planning activities, including expenditures for a detailed engineering study.

In preparing for the analysis, it is important to estimate the capital and operating costs of the CHP system and to establish criteria for assessing economic feasibility. Another important analytical objective is to understand how sensitive the payback period is to variations in operating hours and escalating fuel, electricity, operating, and maintenance costs. 
A very useful software tool for performing economic feasibility evaluations is known as the "Cogeneration Ready Reckoner." 9 The methodology on which this tool is based involves a comparison of annualized differences between a benchmark case without cogeneration and a cogeneration case. By analyzing capital and operating costs of both benchmark and cogeneration systems, the software helps boiler owners and operators establish a basis for optimizing the system and justifying the financial investment. Results of the screening analysis also help estimate the approximate size of the CHP system and its construction cost and determine the most appropriate type of prime mover to be used and its design and operating philosophy.

In the benchmark case, the thermal and electrical parameters that would apply at the site if cogeneration is not installed are defined. This generally involves the following considerations:

- steam, hot water, and electricity usage and expected load growth;

- operating and maintenance costs, including boiler fuel and electricity purchased from the local utility;

- construction and finance costs; and

- various tariffs paid for the fuel and electricity.

The analysis of the cogeneration case involves selecting one of the preliminary CHP designs for review and identifying the fuel that will power the CHP system. Note that the CHP fuel may be different from the fuel used in the benchmark case. Other factors that need to be estimated and used as input include operating and maintenance costs, capital costs, and tariffs. Parameters that can be evaluated by the "Cogeneration Ready Reckoner" include

- operating periods where up to 12 operating periods can be separately entered to study the effects of different thermal and electrical demand cycles and applicable tariffs on cash flow,

- operating modes where two different sets of operating hours can be entered to simulate normal operating conditions and conditions when one or more prime movers are out of service,

- debt repayment and interest, and

- time-dependent degradation of equipment performance.

Useful financial results from "Cogeneration Ready Reckoner" analysis include

- benchmark and cogeneration case cash flows,

- benchmark and cogeneration case capital cost profiles,

- cash flow differential (cogeneration cash flows-benchmark cash flows),

- tax and financial costs,

- financial information such as net present value (NPV) and internal rate of return (IRR), and

- sensitivity graphs for the variation in import electricity cost, export electricity value, cogeneration case fuel cost, capital cost, and discount rate.

After the economic screening analysis is completed and the most attractive CHP system is identified, a detailed engineering study is performed. The study objectives are to identify and size the components needed to integrate cogeneration technology into the ICI boiler installation. Knowing this information makes it possible to more accurately estimate construction, operating, and maintenance costs. With the equipment defined, it is possible to analyze energy requirements and costs, characterize part-load performance, and estimate return on investment and payback. To fully understand energy supply and 
demand variations, it may even be necessary to model hour-by-hour system performance. Optimizing the CHP system often requires several iterations of design changes followed by economic reevaluation.

While the cost of the detailed engineering study can be significant, the expenditure should be viewed as the final step toward selection of the most cost-effective CHP system. The reason for conducting the detailed engineering study is to provide the types of site-specific information needed to undertake more costly and time-consuming activities such as negotiations for power, steam, and fuel supply contracts; environmental permits; zoning approval; and project financing.

\subsubsection{Health, Safety, and Environmental Issues}

Careful consideration of health, safety, and environmental issues is necessary during the planning stages of any CHP project because the cost of addressing these issues can impact economic feasibility. Some of these issues may also represent barriers to implementation that could make CHP impractical. Environmental issues typically focus on controlling air and water emissions and obtaining environmental permits. Besides normal industrial health and safety issues common to ICI boiler installations, issues unique to CHP systems may also need to be addressed. For example, certain types of prime movers can create noise and vibrations that are unacceptable, and potentially serious electrical hazards can occur when a CHP system is interconnected with the electrical grid.

\subsubsection{Noise and vibration}

High-speed rotating equipment, such as gas turbines used in CHP systems, is often very noisy. Reducing noise to an acceptable level and minimizing the consequences of objectionable vibrations often involves construction of special noise enclosures or foundation structures to effectively isolate the equipment. While these enclosures and structures may be essential to the health and safety of workers, the cost of their installation can be substantial and should not be discounted.

\subsubsection{Engineered and administrative controls}

Hot and cold surfaces associated with power piping, boiler jackets, heat exchangers, exhaust gas ducts, mufflers, and refrigeration equipment used in CHP systems represent health and safety concerns that are common to many industries. To reduce the potential for personal injury, it may be necessary to apply engineered barriers at strategic locations to properly protect workers. These barriers may involve use of personal protective equipment or installation of physical barriers such as gates, doors, handrails, insulation, guards, and shields. For some hazards, it may also be necessary to establish administrative controls to supplement the engineered barriers. The cost of applying necessary engineered and administrative controls should be included in the construction and operating cost estimates for the CHP system.

\subsubsection{Electrical hazards}

Safety issues associated with the interconnection of a CHP system to the electrical grid are discussed in Sect. 5.4. The phenomenon known as "islanding" is a particular concern because utility workers involved in maintenance or repair of faulty power lines that are serviced by a CHP electrical generator can be exposed to potentially life-threatening electrical hazards. To avoid this problem, many utilities require installation of protective relays and switchgear capable of isolating the CHP system from the electrical grid. Besides the cost of installing and maintaining this equipment, some utilities also require owners of CHP systems to purchase liability insurance to limit the responsibility of the utility or its customers. ${ }^{10}$ Because costs are associated with the installation of utility-required safety equipment and 
premiums for liability insurance, these expenses should be reflected in the economic feasibility evaluations of affected CHP systems.

\subsubsection{Emissions control}

Federal air and water quality regulations are contained in the CAA and the CWA as discussed in Sect. 2.3. These acts authorize EPA to establish federal standards for air and water emissions. Although EPA applies these standards nationwide, state and local regulatory authorities are allowed to establish supplementary emissions standards for air and water quality provided the requirements are at least as stringent as the federal standards.

Satisfying the federal CAA generally requires owners and operators of existing ICI boiler installations to control emissions from newly installed CHP equipment. Techniques commonly used to reduce $\mathrm{NO}_{\mathrm{x}}, \mathrm{SO}_{\mathrm{x}}$, and $\mathrm{PM}$ emissions are described in Tables 4.4-4.6. Selecting one emissions control technique over another depends on many factors, including the type of fuel used to power the CHP system, the types and capacities of existing emission control equipment, and the environmental regulations that apply to the site (attainment or NAA). Emissions rates and technology requirements that apply to new sources of air emissions are summarized in Table 2.5.

Technology-based and water quality-based effluent limits established by EPA under the CWA can influence the way boiler blowdown, cooling tower blowdown, and cooling water must be treated before being released from the site. Treatment and processing of these wastewater streams may be required as part of the National Pollutant Discharge Elimination System (NPDES) permitting process. This process is used by EPA to impose limitations on the discharge of certain pollutants that may be present in these wastewater streams.

Because compliance with CAA and the CWA requirements can be expensive, the cost of required emission control equipment needs to be factored into construction and operating cost estimates.

\subsubsection{Permits}

The CAA establishes permitting requirements for construction and operation of new and modified major stationary sources of regulated air pollutants. Before construction of one of these sources can begin, a permit must be obtained from the regulatory authority having jurisdiction. The type of permit issued and the requirements for obtaining the permit depend on the air quality at the location of the source. As discussed in Sect. 2.3, a CHP system that is a major new source of emissions is subject to either the Prevention of Significant Deterioration (PSD) or the Nonattainment NSR permitting process. Except for some very small CHP systems, almost every cogeneration project needs some type of NSR permit.

Operating permits are issued by the federal government (EPA) as well as state and local jurisdictions. The primary purpose for issuing an operating permit is to record the following information in one document:

- all of the emission control requirements that apply to the source,

- reporting requirements for tracking emissions of regulated pollutants,

- monitoring, testing, and record keeping requirements, and

- annual certification requirements.

These permit provisions ensure that mandated emissions limitations and emission reduction requirements are achieved in actual practice. Additional information about permitting requirements under the CAA is presented in Sect. 2.3.1.4.

Although obtaining construction and operating permits for CHP systems is now well-established, the application, submittal, and review processes can be both technically complex and time-consuming. 
Therefore, to minimize the possibility of delay, permit applications should be completed and submitted as early in the CHP project planning cycle as possible.

Under the NPDES program of the CWA, all facilities that discharge pollutants from any point source into waters of the United States are required to obtain an NPDES permit. The NPDES permitting process for most CHP systems involves obtaining a license for the facility to discharge a specified amount of a pollutant into a receiving water under certain conditions. Major components of an NPDES permit include effluent limits, monitoring and reporting requirements, special conditions, and standard conditions. ${ }^{11}$ Compliance with the terms and conditions of an NPDES permit may require installation of waste stream processing equipment, procurement of chemical agents for treating the waste stream, or disposal of waste products. The equipment and operating costs for complying with NPDES permit requirements should be considered when evaluating the economic viability of a CHP system.

\subsubsection{Electrical Grid Considerations}

As discussed in Sects. 2.4.2 and 5.6, boiler owners and operators need to consider two options when deciding how the CHP system will operate. One option involves interconnecting the CHP system with the electrical grid. This option generally allows installation of a smaller CHP system with electrical generating capacity sufficient to meet most, but not all, of the facility's electrical demand. Because some utilities prohibit CHP systems from operating in parallel with the electrical grid and others refuse to interconnect with these systems, ${ }^{12}$ discussions with utility representatives need to be held at an early stage in the planning process so that strategies for addressing potential barriers to implementation can be formulated.

In situations where interconnection is not possible or prohibitively expensive, project planners can either operate independently of the electrical grid or abandon the project. Operating independently from the electrical grid means that the generating capacity of the CHP system must be adequate to supply all of the power used by the facility during periods of peak demand plus a reserve allowance for short-term power transients. This generally requires installation of a more complex CHP system that includes emergency power generating equipment capable of starting the CHP system after a shutdown. Although no electricity purchases are required to operate in this mode and no interconnection barriers will arise, construction and operating costs of a more complex CHP system could adversely impact project economics.

\subsection{INFORMATION SOURCES}

Information that may be useful to boiler owners and operators who are interested in obtaining a better understanding of cogeneration technology is widely available. Many text books, open-literature publications, and technical reports have been written about this subject, and a number of these documents are cited as references in this guide. Titles, authors, and publication dates for documents that were reviewed while preparing this guide are listed in the references at the end of each chapter.

Numerous World Wide Web sites also contain valuable information about cogeneration technology and provide links to organizations that promote and educate energy users about the economic and energysavings benefits of CHP. Web sites that contain a wide range of background and technical information about cogeneration technology are identified in Table 9.4.

Because the economic benefits of cogeneration technology cannot be guaranteed, it is important for boiler owners and operators to be aware of information sources that are available and to make use of the experience and knowledge base that is presented. Using this information appropriately is key to making informed decisions about successfully applying CHP at new or existing ICI boiler installations. 
Table 9.4. Web sites with information about cogeneration technology

\begin{tabular}{|c|c|c|}
\hline Sponsor & Program or mission & Web site \\
\hline $\begin{array}{l}\text { U.S. Department of Energy } \\
\text { (DOE), Office of Energy, } \\
\text { Efficiency and Renewable } \\
\text { Energy (EERE), Distributed } \\
\text { Energy (DE) Program }\end{array}$ & $\begin{array}{l}\text { Combined Heat and Power (CHP) } \\
\text { Program }\end{array}$ & $\begin{array}{l}\text { www.eere.energy.gov/de/program_area } \\
\text { s/euid_combo_prgrm.shtml }\end{array}$ \\
\hline $\begin{array}{l}\text { U.S. Department of Energy } \\
\text { (DOE), Office of Energy, } \\
\text { Efficiency and Renewable } \\
\text { Energy, (EERE) Federal } \\
\text { Energy Management Program } \\
\text { (FEMP) }\end{array}$ & $\begin{array}{l}\text { Distributed Energy Resources and } \\
\text { Combined Heat and Power }\end{array}$ & $\begin{array}{l}\text { www.eere.energy.gov/femp/technologie } \\
\text { s/derchp.cfm }\end{array}$ \\
\hline $\begin{array}{l}\text { U.S. Department of Energy } \\
\text { (DOE), Office of Energy, } \\
\text { Efficiency and Renewable } \\
\text { Energy (EERE), Industrial } \\
\text { Technologies Program (ITP) }\end{array}$ & BestPractices & www.oit.doe.gov/bestpractices \\
\hline $\begin{array}{l}\text { U.S. Environmental Protection } \\
\text { Agency (EPA) }\end{array}$ & $\begin{array}{l}\text { Combined Heat and Power } \\
\text { Partnership }\end{array}$ & www.epa.gov/chp \\
\hline $\begin{array}{l}\text { New York State Energy Research } \\
\text { and Development Authority } \\
\text { (NYSERDA) }\end{array}$ & $\begin{array}{l}\text { Distributed Generation and } \\
\text { Combined Heat and Power } \\
\text { Program }\end{array}$ & www.nyserda.org/dgchp.html \\
\hline $\begin{array}{l}\text { US Combined Heat and Power } \\
\text { Association (USCHPA) }\end{array}$ & $\begin{array}{l}\text { Mission: Create a regulatory, } \\
\text { institutional and market } \\
\text { environment that fosters the use } \\
\text { of clean, efficient CHP as a } \\
\text { major source of electric power } \\
\text { and thermal energy in the } \\
\text { United States. }\end{array}$ & http://uschpa.admgt.com/ \\
\hline $\begin{array}{l}\text { Midwest Cogeneration } \\
\text { Association (MCA) }\end{array}$ & $\begin{array}{l}\text { Mission: Promote a greater public } \\
\text { understanding of cogeneration, } \\
\text { independent power production, } \\
\text { and distributed generation }\end{array}$ & www.cogeneration.org \\
\hline COGEN Europe & $\begin{array}{l}\text { Mission: Promote the widespread } \\
\text { development of cogeneration in } \\
\text { Europe and worldwide }\end{array}$ & www.cogen.org \\
\hline $\begin{array}{l}\text { International District Energy } \\
\text { Association }\end{array}$ & $\begin{array}{l}\text { Mission: Foster the success of its } \\
\text { members as leaders in } \\
\text { providing reliable, economical, } \\
\text { efficient and environmentally } \\
\text { sound district energy services. }\end{array}$ & www.districtenergy.org/ \\
\hline
\end{tabular}

Additional information about cogeneration technology is also available from the six Regional Application Centers identified in Table 9.5. The purpose of these centers is to facilitate deployment of applicable technologies by working regionally to educate market players on the benefits of CHP technologies, while reducing perceived risk, and identifying and providing specialized support to facilitate the development and execution of key projects. 
Table 9.5 Regional CHP application centers

\begin{tabular}{|c|c|c|}
\hline Region & States & Key contacts \\
\hline Intermountain & $\begin{array}{l}\text { Arizona, Colorado, New Mexico, Utah, } \\
\text { and Wyoming }\end{array}$ & $\begin{array}{l}\text { Patti Case, etc Group, 801-278-1927, } \\
\text { plcase@etcgrp.com }\end{array}$ \\
\hline Mid-Atlantic & $\begin{array}{l}\text { Delaware, Maryland, New Jersey, } \\
\text { Pennsylvania, and Virginia }\end{array}$ & $\begin{array}{l}\text { Reinhard Radermacher, University of Maryland, } \\
\text { 301-405-5286, raderm@umd.edu }\end{array}$ \\
\hline Midwest & $\begin{array}{l}\text { Illinois, Indiana, Iowa, Michigan, } \\
\text { Minnesota, Missouri, Ohio, and } \\
\text { Wisconsin }\end{array}$ & $\begin{array}{l}\text { John Cuttica, UIC Energy Resources Center, } \\
\text { 312-996-4382, cuttica@uic.edu }\end{array}$ \\
\hline Northeast & $\begin{array}{l}\text { Connecticut, Maine, Massachusetts, } \\
\text { New Hampshire, New York, Rhode } \\
\text { Island, and Vermont }\end{array}$ & $\begin{array}{l}\text { Larry Ambs, UMass Amherst, 413-545-2539, } \\
\text { ambs@ ceere.org } \\
\text { Tom Bourgeois, Pace University Energy Project, } \\
\text { 914-422-4227, tbourgeois@ law.pace.edu }\end{array}$ \\
\hline Northwest & $\begin{array}{l}\text { Alaska, Idaho, Montana, Oregon, and } \\
\text { Washington. }\end{array}$ & $\begin{array}{l}\text { David Sjoding, Washington State University, } \\
\text { 360-956-2004, sjodingd@energy.wsu.edu }\end{array}$ \\
\hline Pacific & $\begin{array}{l}\text { California, Hawaii, Nevada, and the } \\
\text { Pacific Territories }\end{array}$ & $\begin{array}{l}\text { Tim Lipman, University of California, Berkeley, } \\
\text { 510-642-4501, telipman@ socrates.berkeley.edu }\end{array}$ \\
\hline
\end{tabular}

\subsection{REFERENCES}

1. J. A. Orlando, Cogeneration Design Guide, American Society of Heating, Refrigerating and AirConditioning Engineers, Inc., Atlanta, Georgia, 1996.

2. Distributed Energy Resources: A How-To Guide, DOE/GO-102002-1520, U.S. Department of Energy, Washington, D.C., May 2002.

3. Guide to Natural Gas Cogeneration, ed., N. E. Hay, The Fairmont Press, Inc., Lilburn, Georgia, 1988.

4. "How to Appraise CHP," Good Practice Guide 227, prepared for the Department of the Environment, Transportation, and the Regions by ETSU, Oxfordshire, England, January 1999.

5. Combined Heat and Power (CHP) Resources Guide, Midwest CHP Application Center, University of Illinois at Chicago, September 2003.

7. N. Petchers, Combined Heating, Cooling and Power Handbook: Technologies and Applications, The Fairmont Press, Inc., Lilburn, Georgia, 2003.

8. "Introduction to Large-Scale Combined Heat and Power," Good Practice Guide 43, prepared for the Department of the Environment, Transportation, and the Regions by ETSU, Oxfordshire, England, March 1999.

9. "Cogeneration Ready Reckoner," User's Manual, Version 3.1, Commonwealth Department of Industry, Tourism, and Resources, Commonwealth of Australia, September 2002.

10. Industrial and Commercial Cogeneration, Office of Technology Assessment, Congressional Board of the 98th Congress, Washington, D.C., February 1983.

11. "Water Permitting 101," Office of Waste Management—Water Permitting, U.S. Environmental Protection Agency. http://www.epa.gov/npdes/pubs/101pape.pdf

12. R. B. Alderfer, M. M. Eldridge, and T. J. Starrs, Making Connections: Case Studies of Interconnection Barriers and Their Impact on Distributed Power Projects, NREL/SR-200-28053, National Renewable Energy Laboratory, Golden, Colorado, May 2000. 


\section{BIBLIOGRAPHY}

"Absorption Cooling, Heating, and Refrigeration Equipment," Chapter 41, ASHRAE HandbookRefrigeration, American Society of Heating, Refrigerating and Air-Conditioning Engineers, Inc., Atlanta, Georgia, 1998.

“Acid Rain Nitrogen Oxides Emission Reduction Program,” 40 CFR 76, U.S. Environmental Protection Agency.

Air Pollution Operating Permit Program Update, Key Features and Benefits, EPA/451/K-98/002, U.S. Environmental Protection Agency, February 1998.

“Air-to-Air Energy Recovery," Chapter 44, ASHRAE Handbook-HVAC Systems and Equipment, American Society of Heating, Refrigerating and Air-Conditioning Engineers, Inc., Atlanta, Georgia, July 6, 2000.

Alderfer, R. B., Eldridge, M. M., and Starrs, T. J., Making Connections: Case Studies of Interconnection Barriers and Their Impact on Distributed Power Projects, NREL/SR-200-28053, National

Renewable Energy Laboratory, Golden, Colorado, May 2000.

“Appeal Procedures for Acid Rain Program," 40 CFR 78, U.S. Environmental Protection Agency.

"Approval Status of State and Local Operating Permits Programs," 40 CFR 70, Appendix A, U.S. Environmental Protection Agency.

Assessment of Replicable Innovative Industrial Cogeneration Applications, Resource Dynamics Corp., Vienna, Virginia, June 2001.

Barr, M. R., "What 15,000+ Permits and Permit Modifications Have Taught Us," presented at the CIBO $\mathrm{NO}_{\mathrm{X}}$ Control XIV Conference, San Diego, California, March 13, 2001.

Basso, T. S., and DeBlasio, R., "IEEE P1547 Series of Standards for Interconnection," NREL/CP-560-34003, National Renewable Energy Laboratory, Golden, Colorado, May 2003.

BestPractices Steam Overview, DOE/GO-102002-1583, Office of Industrial Technologies, Department of Energy, Washington, D.C., October 2002.

Bloch, H. P., A Practical Guide to Steam Turbine Technology, The McGraw-Hill Companies, Inc., New York, 1996.

Bluestein, J., Horgan, S., and Eldridge, M. M., The Impact of Air Quality Regulations on Distributed Generation, NREL/SR-560-31772, National Renewable Energy Laboratory, Golden, Colorado, October 2002.

"Boiler and Combustion Systems Hazards Code," NFPA 85, National Fire Protection Association, Quincy, Massachusetts, February 9, 2001.

"Boilers," Chapter 27, ASHRAE Handbook—HVAC Systems and Equipment, American Society of Heating, Refrigerating and Air-Conditioning Engineers, Inc., Atlanta, Georgia, July 6, 2000.

Bryson, T., Major, W., and Darrow, K., Assessment of On-Site Power Opportunities in the Industrial Sector, ORNL/TM-2001/169, prepared by Onsite Energy Corp. for the Oak Ridge National Laboratory, Oak Ridge, Tennessee, September 2001.

Casten, T. R., Turning Off the Heat: Why America Must Double Energy Efficiency to Save Money and Reduce Global Warming, Prometheus Books, Amherst, New York, 1998.

Chambers, A., Distributed Generation: A Nontechnical Guide, PennWell Corp., Tulsa, Oklahoma, 2001.

CHP Potential at Federal Sites, Office of Energy Efficiency and Renewable Energy, U.S. Department of Energy, Washington, D.C., May 2000.

"Clean Air Act," U.S. Environmental Protection Agency, http://www.epa.gov/oar/caa/contents.html Cogeneration Handbook for the Chemical Process Industry, DOE/NBB-0059, prepared by Pacific Northwest National Laboratory for the U.S. Department of Energy, Washington, D.C., February 1984. 
Cogeneration Handbook for the Food Processing Industry, DOE/NBB-0061, prepared by Pacific Northwest National Laboratory for the U.S. Department of Energy, Washington, D.C., February 1984.

Cogeneration Handbook for the Petroleum Refining Industry, DOE/NBB-0060, prepared by Pacific Northwest National Laboratory for the U.S. Department of Energy, Washington, D.C., February 1984.

Cogeneration Handbook for the Pulp and Paper Industry, DOE/NBB-0057, prepared by Pacific Northwest National Laboratory for the U.S. Department of Energy, Washington, D.C., February 1984.

Cogeneration Handbook for the Textile Industry, DOE/NBB-0058, prepared by Pacific Northwest National Laboratory for the U.S. Department of Energy, Washington, D.C., February 1984.

“Cogeneration Ready Reckoner," User's Manual, Version 3.1, Commonwealth Department of Industry, Tourism, and Resources, Commonwealth of Australia, September 2002.

"Cogeneration Systems and Engine and Turbine Drives," Chapter 7, ASHRAE Handbook-HVAC Systems and Equipment, American Society of Heating, Refrigerating and Air-Conditioning Engineers, Inc., Atlanta, Georgia, July 6, 2000.

Combined Heat and Power (CHP) Resources Guide, Midwest CHP Application Center, University of Illinois at Chicago, September 2003.

Combined Heat and Power: A Federal Manager's Resource Guide, prepared by Aspen Systems Corp. for the U.S. Department of Energy, Washington, D.C., March 2000.

Combustion Fossil Power, 4th ed., ed. Singer, J. G., Combustion Engineering, Inc., Windsor, Connecticut, 1991.

"Comparison of Fatigue Assessment Techniques for Heat Recovery Steam Generators," American

Boiler Manufacturer's Association, Task Group on Cyclic Service, Arlington, Virginia, 2004.

"Consider Steam Turbine Drives for Rotating Equipment," DOE/GO-102002-1475, Steam Tip Sheet 21, U.S. Department of Energy, Washington, D.C., January 2002.

“Continuous Emissions Monitoring," 40 CFR 75, U.S. Environmental Protection Agency.

"Desiccant Dehumidification and Pressure Drying Equipment," Chapter 22, ASHRAE Handbook—HVAC Systems and Equipment, American Society of Heating, Refrigerating and Air-Conditioning Engineers, Inc., Atlanta, Georgia, July 6, 2000.

DG Monitor, Vol. III, Issue 4, Resource Dynamics Corporation, Vienna, Virginia, July/August 2003.

Distributed Energy Resources: A How-To Guide, DOE/GO-102002-1520, U.S. Department of Energy, Washington, D.C., May 2002.

Elliott, R. N., Vendors as Industrial Energy Service Providers, American Council for an Energy-Efficient Economy, Washington, D.C., July 2002.

"Emission Guidelines and Compliance Times for Small Municipal Waste Combustion Units Constructed on or Before August 30, 1999," 40 CFR 60, Subpart BBBB, U.S. Environmental Protection Agency.

"Emission Offset Interpretative Ruling," 40 CFR 51, Appendix S, U.S. Environmental Protection Agency.

Energy Efficiency Handbook, Council of Industrial Boiler Owners, Burke, Virginia, November 1997.

"EPA Administered Permit Programs: The National Pollutant Discharge Elimination System," 40 CFR 122, U.S. Environmental Protection Agency.

"Excess Emissions," 40 CFR 77, U.S. Environmental Protection Agency.

"Federal $\mathrm{NO}_{\mathrm{x}}$ Budget Trading Program," 40 CFR 97, U.S. Environmental Protection Agency.

"Federal Operating Permit Programs," 40 CFR 71, U.S. Environmental Protection Agency.

Final Revisions to the Ozone and Particulate Matter Air Quality Standards, EPA-456/F-97-004, U.S. Environmental Protection Agency, July 1997.

Gas Transmission and Distribution Piping Systems, ASME B31.8-2000, American Society of Mechanical Engineers, New York, 2000. 
Gas Turbine Control and Protection Systems, ANSI B133.4-1978 (Reaffirmed 1997), American Society of Mechanical Engineers, New York, 1978.

Gas Turbine Fuels, ANSI/ASME B133.7M-1985 (Reaffirmed 2001), American Society of Mechanical Engineers, New York, 1985.

Gas Turbine Installation Sound Emissions, ANSI B133.8-1977 (Reaffirmed 2001), American Society of Mechanical Engineers, New York, 1977.

Gas Turbine World Handbook, Pequot Publishing, Inc., Fairfield, Connecticut, 2003.

Gas Turbines for the Petroleum, Chemical, and Gas Industry Services, API Standard 616, 4th ed., American Petroleum Institute, Washington, D.C., August 1998.

Gas Turbines: Procurement, Part 1: General Introduction and Definitions, ASME 3977 1-2000, American Society of Mechanical Engineers, New York, 2000.

Gas Turbines: Procurement, Part 2: Standard Reference Conditions and Ratings, ASME 3977 2-2000, American Society of Mechanical Engineers, New York, 2000.

Gas Turbines-Acceptance Tests, ISO 2314, International Organization for Standardization, Geneva Switzerland, 1999.

Govan, F. A., Permitting Requirements for Industrial, Commercial, and Institutional Boilers, Pendent Media, Inc., Cleveland, Ohio, November 2000.

Guidance for Evaluation of Measurement Uncertainty in Performance Tests of Steam Turbines, ASME PTC 6 Report-1985 (Reaffirmed 1997), American Society of Mechanical Engineers, New York, 1985.

Guide to Natural Gas Cogeneration, ed., N. E. Hay, The Fairmont Press, Inc., Lilburn, Georgia, 1988.

Guideline for Gas and Oil Emission Factors for Industrial, Commercial, and Institutional (ICI) Boilers, American Boiler Manufacturers Association, Arlington, Virginia, 1997.

"Heat Exchangers," Chapter 43, ASHRAE Handbook-HVAC Systems and Equipment, American Society of Heating, Refrigerating and Air-Conditioning Engineers, Inc., Atlanta, Georgia, July 6, 2000.

Heat Recovery Steam Generators, API Publication 534, 1st ed., American Petroleum Institute, Washington, D.C., 1995.

Hirschenhofer, J. H., Stauffer, D. B., Engleman, R. R., and Klett, M. G., Fuel Cell Handbook, 4th ed., DOE/FETC-99/1076, U.S. Department of Energy, Office of Fossil Energy, Morgantown, West Virginia, November 1998.

Hite, R., Cogeneration/Combined Heat and Power: An Overview, Cogeneration and Competitive Power Journal, ed., F. W. Payne, Vol. 17, No. 3, Summer 2002, pp. 64-79.

"How to Appraise CHP," Good Practice Guide 227, prepared for the Department of the Environment, Transportation, and the Regions by ETSU, Oxfordshire, England, January 1999.

Iannucci, J., Horgan, S., Eyer, J., and Cibulka, L., Air Pollution Emission Impacts Associated with Economic Market Potential of Distributed Generation in California, prepared for the California Air Resources Board and the California Environmental Protection Agency, prepared by Distributed Utility Associates, Livermore, California, June 2000.

Illinois CHP/BCHP Environmental Permitting Guidebook, Volume A: Roadmapping the Permitting Process, prepared for the Illinois Department of Commerce and Community Affairs, U.S. Department of Energy Chicago Regional Office by the University of Illinois at Chicago-Energy Resources Center, January 23, 2003.

Illinois CHP/BCHP Environmental Permitting Guidebook, Volume B: Permitting Issues (A Survey And Dialogue), prepared for the Illinois Department of Commerce and Community Affairs, U.S. Department of Energy Chicago Regional Office by the University of Illinois at Chicago-Energy Resources Center, January 23, 2003.

Improving Steam System Performance: A Sourcebook for Industry, DOE/GO-102002-1557, prepared by Lawrence Berkeley National Laboratory for the U.S. Department of Energy, Washington, D.C., June 2002. 
Industrial and Commercial Cogeneration, Office of Technology Assessment, Congressional Board of the 98th Congress, Washington, D.C., February 1983.

Industrial Steam System Heat-Transfer Solutions, DOE/GO-102003-1738, U.S. Department of Energy, Washington, D.C., June 2003.

Inspection of Fired Boilers and Heaters, API Recommended Practice 573, 2nd ed., American Petroleum Institute, Washington, D.C., February 2003.

Inspection of Pressure Vessels (Towers, Drums, Reactors, Heat Exchangers, and Condensers), API Recommended Practice 572, 2nd ed., American Petroleum Institute, Washington, D.C., February 2001.

Inspection Practices for Piping System Components, API Recommended Practice 574, 2nd ed., American Petroleum Institute, Washington, D.C., June 1998.

Instrumentation and Control Systems for Fired Heaters and Steam Generators, API Recommended Practice 556, 1st ed., American Petroleum Institute, Washington, D.C., May 1997.

"Introduction to Large-Scale Combined Heat and Power," Good Practice Guide 43, prepared for the Department of the Environment, Transportation, and the Regions by ETSU, Oxfordshire, England, March 1999.

Inverters, Converters, and Controllers for Use in Independent Power Systems, UL 1741, Underwriters Laboratories, Inc., Northbrook, Illinois, January 17, 2001.

Laitner, J., Parks, W., Schilling, J., and Scheer, R., Federal Strategies to Increase the Implementation of Combined Heat and Power Technologies in the United States, publisher and publication date unknown.

"Land-Based Steam Turbine Generator Sets 0-33,000 kW," NEMA Standards Publication No. SM 24-1991 (R1997, R2002), National Electrical Manufacturers Association, Rosslyn, Virginia, 1991.

Limaye, D. R., Industrial Cogeneration Applications, The Fairmont Press, Inc., Lilburn, Georgia, 1987.

Limaye, D. R., Planning Cogeneration Systems, The Fairmont Press, Inc., Atlanta, Georgia, 1985.

Measurement of Exhaust Emissions from Stationary Gas Turbine Engines, ASME B133.9-1994 (Reaffirmed 2001), American Society of Mechanical Engineers, New York, 1994.

Mulder, D. E., and Ventrice, M. B., Cogeneration in Tennessee: A Handbook, Tennessee Technological University, Cookeville, Tennessee, August 1986.

National Board Inspection Code, 2001 Edition, NB 23, The National Board of Boiler and Pressure Vessel Inspections, Columbus, Ohio, 2001.

"National Emission Standards for Hazardous Air Pollutants for Industrial/Commercial/Institutional Boilers and Process Heaters; Proposed Rule" Federal Register, 68, No. 8, 1660-1763, January 13, 2003.

National Emission Standards for Hazardous Air Pollutants for Industrial, Commercial, and Institutional Boilers and Process Heaters, OAR-2002-0058; RIN 2060-AG69, U.S. Environmental Protection Agency, Washington, D.C.

"National Emission Standards for Hazardous Air Pollutants for Source Categories," 40 CFR 63, U.S. Environmental Protection Agency.

"National Emission Standards for Hazardous Air Pollutants for Stationary Gas Turbines; Proposed Rule," Federal Register, 68, No. 9, 1888-1929, January 14, 2003.

"National Emission Standards for Hazardous Air Pollutants for Stationary Reciprocating Internal Combustion Engines; Proposed Rule," Federal Register, 67, No. 244, 77830-77874, December 19, 2002.

"National Emission Standards for Hazardous Air Pollutants for Stationary Gas Turbines; Final Rule," Federal Register, 69, No. 9, 10512-10548, March 5, 2004. 
National Emission Standards for Hazardous Air Pollutants for Stationary Reciprocating Internal Combustion Engines, OAR-2002-0059; RIN 2060-AG-63, U.S. Environmental Protection Agency, Washington, D.C.

National Emission Standards for Hazardous Air Pollutants for Stationary Combustion TurbinesProposed Delisting, OAR-2003-0189; RIN 2060-AK73, U.S. Environmental Protection Agency, Washington, D.C.

National Emission Standards for Hazardous Air Pollutants for Stationary Combustion Turbines-Stay Proposal, OAR-2003-0196; RIN 2060-AK73, U.S. Environmental Protection Agency, Washington, D.C.

"National Emission Standards for Hazardous Air Pollutants from Hazardous Waste Combustors," 40 CFR 63, Subpart EEE, U.S. Environmental Protection Agency.

National Fuel Gas Code, NFPA 54, National Fire Protection Association, Quincy, Massachusetts, July 19, 2002.

"New Source Review: Applicability Determination for Cycle Gas Turbine Systems: Response letter to PM Raher," Letter from John S. Seitz, Director, Office of Air Quality Planning and Standards, U.S. Environmental Protection Agency, to Mr. Patrick M. Raher, Hogan \& Hogan L.L.P., Washington, D.C., August 6, 2001. http://www.epa.gov/ttn/oarpg/t5pgm.html

"1999 Interconnection Guidelines for Distributed Generation in Texas," Public Utility Commission of Texas, February 4, 1999. http://www.puc.state.tx.us/electric/projects/20363/guidlns.cfm

"NO $\mathrm{N}_{\mathrm{x}}$ Budget Trading Program for State Implementation Plans," 40 CFR 96, U.S. Environmental Protection Agency.

Oland, C. B., Guide to Low-Emission Boiler and Combustion Equipment Selection, ORNL/TM-2002/19, Oak Ridge National Laboratory, Oak Ridge, Tennessee, April 2002.

Orlando, J. A., Cogeneration Design Guide, American Society of Heating, Refrigerating and AirConditioning Engineers, Inc., Atlanta, Georgia, 1996.

Orlando, J. A., Cogeneration Planner's Handbook, The Fairmont Press, Inc., Lilburn, Georgia, 1991.

Output-Based Regulations: A Handbook for Air Regulators, Draft Final Report, U.S. Environmental Protection Agency, April 22, 2004.

Payne, F. W., Cogeneration Sourcebook, The Fairmont Press, Inc., Atlanta, Georgia, 1985.

Peltier, R., "Repowering Breathes New Life into Old Plants," Power, 147(5) (June 2003).

Performance Test Code on Air Heaters, ASME PTC 4.3 (Reaffirmed 1991), American Society of Mechanical Engineers, New York, 1968.

Performance Test Code on Atmospheric Water Cooling Equipment, ASME PTC 23-1986 (Reaffirmed 1997), American Society of Mechanical Engineers, New York, 1986.

Performance Test Code on Compressors and Exhausters, ASME PTC 10-1997, American Society of Mechanical Engineers, New York, 1997.

Performance Test Code on Fired Steam Generators, ASME PTC 4-1998, American Society of Mechanical Engineers, New York, 1998.

Performance Test Code on Fuel Cell Power Systems Performance, ASME PTC 50-2002, American Society of Mechanical Engineers, New York, 2002.

Performance Test Code on Gas Turbine Heat Recovery Steam Generators, ASME PTC 4.4-1981 (Reaffirmed 2003), American Society of Mechanical Engineers, New York, 1981.

Performance Test Code on Gas Turbines, ASME PTC 22-1997, American Society of Mechanical Engineers, New York, 1997.

Performance Test Code on Overall Plant Performance, ASME PTC 46-1996, American Society of Mechanical Engineers, New York, 1996.

Performance Test Code on Reciprocating Internal-Combustion Engines, ASME PTC 17-1973 (Reaffirmed 2003), American Society of Mechanical Engineers, New York, 1973. 
Performance Test Code on Steam Surface Condensers, ASME PTC 12.2-1998, American Society of Mechanical Engineers, New York, 1998.

Performance Test Code on Steam Turbines, ASME PTC 6-1996, American Society of Mechanical Engineers, New York, 1996.

"Permit Requirements," 40 CFR 51.165, U.S. Environmental Protection Agency.

"Permits Regulation," 40 CFR 72, U.S. Environmental Protection Agency.

Petchers, N., Combined Heating, Cooling and Power Handbook: Technologies and Applications, The Fairmont Press, Inc., Lilburn, Georgia, 2003.

Petroleum, Petrochemical, and Natural Gas Industries_Steam Turbines-Special-purpose Applications, API Standard 612, 5th ed., American Petroleum Institute, Washington, D.C., July 2003.

Popovic, P., Radermacher, R., Marantan, A., and Garland, P., Integration of Microturbine with SingleEffect Exhaust-Driven Absorption Chiller and Solid Wheel Desiccant System, HI-02-5-3, American Society of Heating, Refrigerating and Air-Conditioning Engineers, Inc., Atlanta, Georgia, 2002.

Power Piping, ASME B31.1-2001, American Society of Mechanical Engineers, New York, 2001.

"Prevention of Significant Deterioration (PSD) and Nonattainment New Source Review (NSR): Baseline Emissions Determination, Actual-to-Future-Actual Methodology, Plantwide Applicability Limitations, Clean Units, Pollution Control Projects," Federal Register, 67, No. 251, 80186-80289, December 31, 2002.

"Prevention of Significant Deterioration of Air Quality Requirements," 40 CFR 51.166, U.S. Environmental Protection Agency.

"Prevention of Significant Deterioration of Air Quality," 40 CFR 52.21, U.S. Environmental Protection Agency.

"Primary and Secondary National Ambient Air Quality Standards," 40 CFR 50, U.S. Environmental Protection Agency.

Procedures for Routine Performance Tests of Steam Turbines, ASME PTC 6S Report-1988 (Reaffirmed 1995), American Society of Mechanical Engineers, New York, 1988.

Process Piping, ASME B31.3-2002, American Society of Mechanical Engineers, New York, 2002.

Procurement Standard for Gas Turbine Auxiliary Equipment, ANSI B133.3-1981 (Reaffirmed 1994), American Society of Mechanical Engineers, New York, 1981.

Procurement Standard for Gas Turbine Electrical Equipment, ANSI B133.5-1978 (Reaffirmed 1997), American Society of Mechanical Engineers, New York, 1978.

Procurement Standard for Gas Turbine Information to be Supplied by User and Manufacturer, ANSI B133.10-1981 (Reaffirmed 1994), American Society of Mechanical Engineers, New York, 1981.

Procurement Standard for Gas Turbine Maintenance and Safety, ANSI B133.12-1981 (Reaffirmed 2001), American Society of Mechanical Engineers, New York, 1981.

Procurement Standard for Gas Turbine Preparation for Shipping and Installation, ANSI B133.11-1982 (Reaffirmed 1994), American Society of Mechanical Engineers, New York, 1982.

"Reciprocating Internal Combustion Engine Driven Alternating Current Generating Sets-Part 1: Application, Rating and Performance," ISO 8528-1, 1st ed., International Organization for Standardization, Geneva, Switzerland, January 1, 1993.

"Reciprocating Internal Combustion Engine Driven Alternating Current Generating Sets-Part 2: Engines," ISO 8528-2, 1st ed., International Organization for Standardization, Geneva Switzerland, January 1, 1993.

"Reciprocating Internal Combustion Engine Driven Alternating Current Generating Sets-Part 3: Alternating Current Generators for Generating Sets," ISO 8528-3, 1st ed., International Organization for Standardization, Geneva, Switzerland, January 1, 1993.

"Reciprocating Internal Combustion Engine Driven Alternating Current Generating Sets-Part 5: Generating Sets," ISO 8528-5, 1st ed., International Organization for Standardization, Geneva, Switzerland, January 1, 1993. 
Reciprocating Internal Combustion Engines - Performance - Part 4: Speed Governing, ISO 3046-4, 2nd ed., International Organization for Standardization, Geneva, Switzerland, March 15, 1987.

Reciprocating Internal Combustion Engines-Performance-Part 1: Declarations of Power, Fuel and Lubricating Oil Consumptions, and Test Methods-Additional Requirements for Engines for General Use, ISO 3046-1, 5th ed., International Organization for Standardization, Geneva, Switzerland, May 1, 2002.

Reciprocating Internal Combustion Engines-Performance-Part 3: Test Measurements, ISO 3046-3, 2nd ed., International Organization for Standardization, Geneva Switzerland, January 1, 1989.

Reciprocating Internal Combustion Engines-Performance-Part 5: Torsional Vibrations, and Test Methods-Additional Requirements for Engines for General Use, ISO 3046-5, 2nd ed., International Organization for Standardization, Geneva Switzerland, December 1, 2001.

Reciprocating Internal Combustion Engines-Performance_Part 6: Overspeed Protection, ISO 3046-6, 3rd ed., International Organization for Standardization, Geneva, Switzerland, October 1, 1990.

Recommended Practice for Installation, Maintenance, and Operation of Internal-Combustion Engines, API Recommended Practice 7C-11F, 1st ed., American Petroleum Institute, Washington, D.C., November 1, 1994.

Recommended Practice for Packaged Combustion Gas Turbines, API Recommended Practice 11PGT, 1st ed., American Petroleum Institute, Washington, D.C., May 1, 1992.

Recommended Practices for the Prevention of Water Damage to Steam Turbines Used for Electric Power Generation, ASME TDP 1-1998, American Society of Mechanical Engineers, New York, 1998.

Renewable Energy and Distributed Generation Guidebook, prepared for Massachusetts Division of Energy Resources, prepared by Environmental Futures, Inc., Boston, Massachusetts, April 2001.

Review of Combined Heat and Power Technologies, Office of Industrial Technologies, U.S. Department of Energy, Washington, D.C., October 1999.

"Section I: Power Boilers," 2001 ASME Boiler and Pressure Vessel Code, American Society of Mechanical Engineers, New York, 2001.

"Section IV: Heating Boilers," 2001 ASME Boiler and Pressure Vessel Code, American Society of Mechanical Engineers, New York, 2001.

"Section VI: Recommended Rules for the Care and Operation of Heating Boilers," 2001 ASME Boiler and Pressure Vessel Code, American Society of Mechanical Engineers, New York, 2001.

"Section VII: Recommended Guidelines for the Care of Power Boilers," 2001 ASME Boiler and Pressure Vessel Code, American Society of Mechanical Engineers, New York, 2001.

Shipley, A. M., Green, N., McCormack, K., Li, J., and Elliott, R. N., Certification of Combined Heat and Power Systems: Establishing Emissions Standards, Report No. IE014, American Council for an Energy-Efficient Economy, Washington, D.C., September 2001.

"Source Determinations for Combined Heat and Power Facilities under the Clean Air Act New Source Review and Title V Programs," Draft Memorandum, John S. Seitz, Director, Office of Air Quality Planning and Standards, OAR (MD-10), U.S. Environmental Protection Agency, October 15, 2001.

"Standard Classification of Coals by Rank," ASTM Designation: D 388-99, American Society of Testing and Materials, West Conshohocken, Pennsylvania, 1999.

Standard for Interconnecting Distributed Resources with Electric Power Systems, IEEE Standard No. 1547-2003, Institute of Electrical and Electronics Engineers, New York, 2003.

"Standard Practice for Use of Scrap Tire-Derived Fuel," ASTM Designation: D 6700-01, American Society of Testing and Materials, West Conshohocken, Pennsylvania, 2001.

"Standard Specification for Diesel Fuel Oils," ASTM Designation: D 975-03, American Society of Testing and Materials, West Conshohocken, Pennsylvania, 2003.

"Standard Specification for Fuel Oils," ASTM Designation: D 396-02, American Society of Testing and Materials, West Conshohocken, Pennsylvania, 2002. 
"Standard Specification for Gas Turbine Fuel Oils," ASTM Designation: D 2880-03, American Society of Testing and Materials, West Conshohocken, Pennsylvania, 2003.

"Standard Specification for Liquefied Petroleum (LP) Gases," ASTM Designation: D 1835-03, American Society of Testing and Materials, West Conshohocken, Pennsylvania, 2003.

"Standards for the Installation of Stationary Fuel Cell Power Plants," NFPA 853, National Fire Protection Association, Quincy, Massachusetts, August 18, 2000.

"Standards of Performance for Large Municipal Waste Combustors for Which Construction is Commenced After September 20, 1994, or for Which Modification or Reconstruction is Commenced After June 19, 1996," 40 CFR 60, Eb, U.S. Environmental Protection Agency.

"Standards of Performance for New Stationary Sources," 40 CFR 60, U.S. Environmental Protection Agency.

"Standards of Performance for Small Municipal Waste Combustion Units for Which Construction is Commenced After August 30, 1999 or for Which Modification or Reconstruction is Commenced After June 6, 2001," 40 CFR 60, Subpart AAAA, U.S. Environmental Protection Agency.

"Standards of Performance for Stationary Gas Turbines," Federal Register, 68, No. 71, 17990-18002, April 14, 2003.

"State Operating Permit Programs," 40 CFR 70, U.S. Environmental Protection Agency.

"Statutory Restrictions on New Sources," 40 CFR 52.24, U.S. Environmental Protection Agency.

Steam Digest 2001, DOE/GO-102002-1516, Office of Industrial Technologies, U.S. Department of Energy, Washington, D.C., January 2002.

Steam System Opportunity Assessment for the Pulp and Paper, Chemical Manufacturing, and Petroleum Refining Industries, DOE/GO-102002-1639, Office of Industrial Technologies, U.S. Department of Energy, Washington, D.C., September 2002.

Steam System Opportunity Assessment for the Pulp and Paper, Chemical, Manufacturing, and Petroleum Refining Industries, Main Report, DOE/GO-102002-1639, U.S. Department of Energy, Washington, D.C., September 2002.

Steam System Opportunity Assessment for the Pulp and Paper, Chemical, Manufacturing, and Petroleum Refining Industries, Appendices, DOE/GO-102002-1640, U.S. Department of Energy, Washington, D.C., October 2002.

"Steam Turbines for Mechanical Drive Service," NEMA Standards Publication No. SM 23-1991 (R1997, R2002), National Electrical Manufacturers Association, Rosslyn, Virginia, 1991.

Steam, Its Generation and Use, 40th ed., eds. Stultz, S. C., and Kitto, J. B., Babcock and Wilcox, Barberton, Ohio, 1992.

"Sulfur Dioxide Allowance System," 40 CFR 73, U.S. Environmental Protection Agency.

"Sulfur Dioxide Opt-Ins," 40 CFR 74, U.S. Environmental Protection Agency.

Technology Characterization: Fuel Cells, prepared by Energy Nexus Group for the U.S. Environmental Protection Agency, Washington, D.C., April 2002.

Technology Characterization: Gas Turbines, prepared by Energy Nexus Group for the U.S. Environmental Protection Agency, Washington, D.C., February 2002.

Technology Characterization: Microturbines, prepared by Energy Nexus Group for the U.S. Environmental Protection Agency, Washington, D.C., March 2002.

Technology Characterization: Reciprocating Engines, prepared by Energy Nexus Group for the U.S. Environmental Protection Agency, Washington, D.C., February 2002.

Technology Characterization: Steam Turbines, prepared by Energy Nexus Group for the U.S. Environmental Protection Agency, Washington, D.C., March 2002.

Test Code for Steam Turbines, Appendix A to PTC 6, ASME PTC 6A-2001, American Society of Mechanical Engineers, New York, 2001.

"The Clean Air Act Amendments of 1990 Overview," U.S. Environmental Protection Agency, http://www.epa.gov/oar/caa/overview.txt 
The Market and Technical Potential for Combined Heat and Power in the Commercial/Institutional Sector, prepared for the U.S. Department of Energy by ONSITE SYCOM Energy Corporation, Washington, D.C., January 2000 (Revision 1).

"Use Low-Grade Waste Steam to Power Absorption Chillers," DOE/GO-102001-1277, Steam Tip Sheet 14, U.S. Department of Energy, Washington, D.C., May 2001.

"Water Permitting 101," Office of Waste Management-Water Permitting, U.S. Environmental Protection Agency. http://www.epa.gov/npdes/pubs/101pape.pdf

"Wet Electrostatic Precipitation Demonstrating Promise for Fine Particulate Control," Power Engineering, PennWell Corp. Tulsa, Oklahoma, January 2001. 


$$
\text { B-10 }
$$




\section{GLOSSARY}

Absorption chiller: A cooling machine that uses heat as the primary source of energy for driving an absorption refrigeration cycle. Absorption chillers are classified as either indirect-fired, heat-recovery, or direct-fired units.

Aftercooler: A gas-to-liquid (air-to-water) heat exchanger that removes heat from reciprocating engine turbochargers.

Air Quality Related Values (AQRV): A term used by the Environmental Protection Agency (EPA) to represent all values possessed by an area, such as a national park, that may be affected by changes in air quality including all assets of an area whose visibility, significance, or integrity are dependent upon the air environment.

Alkaline fuel cell (AFC): A type of fuel cell that is very efficient and has been used successfully in the space program. Alkaline fuel cells require very pure hydrogen that is expensive to produce, and for this reason they are not considered major contenders for the stationary power market.

Alternating current (ac): An electric current that reverses direction sinusoidally. In the United States, most electrical current is ac at 60 cycles/s.

Apparent power: The vector sum of real power and reactive power. Electrical generators are typically rated in units of kilovolt-amp (kVA). This apparent or total power rating is the product of the generator rated voltage and the rated maximum current.

Area source: Any small source of nonnatural air pollution that is released over a small area but that cannot be classified as a point source. Such sources may include vehicles, fireplaces, woodstoves, and small fuel combustion engines.

Attainment area: An area considered to have air quality as good as or better than the National Ambient Air Quality Standards as defined in the Clean Air Act. An area may be an attainment area for one or more criteria pollutants and a nonattainment area for the others.

Avoided cost: The incremental cost to an electric power producer to generate or purchase a unit of electricity or capacity, or both, but which is instead provided by a third party or which is not needed due to energy conservation and efficiency.

Backup tariff: A fee or tariff charged to a CHP system owner or operator by the electrical supplier that provides electrical energy to the site when on-site electrical generating equipment cannot satisfy the demand.

Base load: The level of demand, for heat or electricity, that exists for the majority of the operating period. Demand will rarely be less than the base load.

Base-loaded design and operation: An operating mode in which the combined heat and power (CHP) system is interconnected to the electrical grid and sized to meet the site's base-load requirements. By operating in this mode, part-load operation is avoided, no redundant capacity is required, and only supplemental power in excess of the base load is purchased from the electric utility.

Best Available Control Technology (BACT): Emission control technology based on the maximum degree of emission reduction (considering energy, environmental, and economic impacts and other costs) achievable through application processes and available methods, systems, and techniques. Use of BACT is permitted by the authority having jurisdiction on a case-by-case basis for major new or modified emissions sources in attainment areas and applies to each regulated pollutant. In no event does the use of BACT permit emissions in excess of those allowed under any applicable Clean Air Act provisions.

Bias firing (BF): An emission control technique that involves injecting more fuel to some burners (typically the lower burners) while reducing fuel to other burners (typically the upper burners) to create staged combustion conditions inside a boiler. This technique decreases the excess oxygen concentration and thereby reduces the formation of nitrogen oxides during combustion. 
Boiler efficiency: A value that characterizes the amount of heat captured by the boiler or HRSG and transferred to the water, compared to the heat input. Boiler efficiency is a function of boiler losses and combustion losses.

Bottoming cycle: A heat-recovery scheme in which high-temperature thermal energy is produced and first used for industrial applications such as glass processing and metal smelting furnaces. Waste heat recovered from the industrial process is then used to drive a turbine to produce electric power.

British thermal unit (Btu): The amount of energy required to raise the temperature of a pound of water $1^{\circ} \mathrm{F}$ from $39.2^{\circ} \mathrm{F}$.

Burner tuning (BT): An emission control technique that limits the amount of excess oxygen available for combustion and thereby reduces formation of nitrogen oxides.

Burners out of service (BOOS): An emission control techniques that reduces the formation of nitrogen oxides. In this technique, certain burners are removed from service by stopping fuel flow but maintaining air flow to create staged combustion conditions inside a boiler.

Buy-back rate: The rate paid to a CHP system owner or operator by the electrical supplier for the excess electricity generated by the CHP system.

Carbon dioxide $\left(\mathbf{C O}_{2}\right)$ : An odorless, colorless gas formed during respiration and by the decomposition of organic substances. Carbon dioxide is also produced when fuel is burned.

Carbon monoxide (CO): An odorless gas produced when fuel is burned. Carbon monoxide is one of the six criteria pollutants for which the EPA has established National Ambient Air Quality Standards.

CHP electrical efficiency: A measure of the amount of fuel energy converted into electricity. In numerical terms, CHP electrical efficiency is a function of the net electricity generated and the total fuel input expressed as follows:

\section{Net electricity generated/Total fuel input}

Clean Air Act (CAA): A 1970 federal law for regulating air quality. The CAA was further expanded by amendments in 1977 and 1990. The 1990 CAA Amendments authorize the Environmental Protection Agency to establish standards for a number of atmospheric pollutants.

Clean Water Act (CWA): A 1977 federal law that amended the Federal Water Pollution Control Act of 1972 and was substantially modified by the Water Quality Act of 1987. This legislation established the basic structure for regulating discharges of pollutants into the waters of the United States. The 1987 amendments to the CWA significantly changed the thrust of enforcement activities. Greater emphasis is now placed on monitoring and control of toxic constituents in wastewater, the permitting of outfalls composed entirely of storm water, and the imposition of regulations governing sewage sludge disposal. These changes resulted in much stricter discharge limits and greatly expanded the number of chemical constituents monitored in the effluent.

Code of Federal Regulations (CFR): A series of volumes in which federal regulations are codified (e.g., Title 40, Protection of the Environment).

Cogeneration technology: A technology in which conventional power generation systems have the means to make use of the energy remaining in exhaust gases, cooling systems, or other energy waste streams. Application of cogeneration technology offers energy and environmental benefits over electriconly and thermal-only systems in both central and distributed power generation applications.

Combined cycle: A term referring to the combination of two or more heat-recovery schemes to extract the most energy from the fuel. Typically, the exhaust from a gas turbine that is coupled to an electrical generator is used to produce steam that then drives a steam turbine coupled to another electrical generator. This increases the efficiency of electricity generation to about $50 \%$.

Combined heat and power (CHP): The sequential production of two forms of useful energy from a single fuel source. In most CHP applications, chemical energy in fuel is converted to both mechanical and thermal energy. The mechanical energy is generally used to generate electricity while the thermal energy 
or heat is used to produce steam, hot water, or hot air. Depending on the application, CHP is referred to by various names including cogeneration, Building Cooling, Heating, and Power (BCHP); Cooling, Heating, and Power for Buildings (CHPB); Combined Cooling, Heating, and Power (CCHP); Integrated Energy Systems (IES), or Distributed Energy Resources (DER).

Compression ignition (CI) engine: A reciprocating internal combustion engine that compresses air until the air temperature is higher than the fuel ignition temperature. At that point in the cycle, fuel is injected into the cylinder where it spontaneously ignites, burns, and expands against the piston. Diesel engines are characterized as CI engines.

Criteria pollutants: The 1990 amendments to the CAA required the EPA to set National Ambient Air Quality Standards for certain pollutants known to be hazardous to human health. The EPA has identified and set standards for six criteria pollutants: ozone, carbon monoxide, total suspended particulates, sulfur dioxide, lead, and nitrogen dioxide.

Demand charge: A fee or tariff charged for the use of electricity based on the maximum power requirement, electrical demand, during a specified period of time, typically a month $(\$ / \mathrm{kW})$.

Desiccant dehumidifier: A machine that uses heat to achieve a cooling effect by removing water vapor from an air stream thereby decreasing the latent cooling load. Desiccant dehumidifiers use materials known as desiccants that naturally remove moisture from humid air. As the desiccant become saturated, it looses its ability to remove moisture and must be either replaced or recharged. Recharging a desiccant involves increasing its temperature to expel the captured moisture.

Desiccant: A material that naturally attracts moisture from gases and liquids. As moisture is adsorbed, it collects on the surface of the desiccant and the desiccant becomes saturated. When heated, the desiccant dries out, or regenerates, and can be used again. Some common desiccants include silica gel, activated alumina, alumina oxide, and deliquescent absorbents such as lithium chloride ( $\mathrm{LiCl})$ and calcium chloride $\left(\mathrm{CaCl}_{2}\right)$.

Direct current (dc): An electric current that steadily flows in the same direction over a sustained period of time as compared to alternating current that oscillates as a function of time.

Ebullient cooling system: A cooling system for reciprocating internal combustion engines that uses natural circulation of a boiling coolant such as treated water to remove heat. In operation, pressurized coolant enters the engine near the bottom where the heat causes part of the coolant to boil generating twophase flow. Because only part of the coolant boils, heat rejection occurs at a constant temperature with less thermal stress to the engine. The formation of bubbles lowers the density of the coolant and causes natural circulation to the top of the engine.

Economically dispatched: An operating approach for a CHP system that factors in the value of purchased power and boiler fuel costs relative to CHP system fuel and maintenance costs and the ability to use recoverable heat. By operating in this mode, it is possible to use microprocessor control systems to perform real-time calculations of operating costs and cost savings as a basis for making operating decisions.

Effective electrical efficiency: A function of the steam turbine electric power output and the total fuel input expressed as follows:

Steam turbine electric power output/[Total fuel input—(Steam to process/Boiler efficiency)]

Electrical generator: An electromagnetic device that converts mechanical or shaft power into electrical energy. Electrical generators that produce alternating current power are categorized as either synchronous or induction generators.

Electrostatic precipitator (ESP): A postcombustion emission control device used to remove particulate matter suspended in flue gas. Separation within an ESP is accomplished by electrically charging the particles. As the particles take on a negative charge, they migrate toward positively charged collector plates, thereby cleaning the flue gas. 
Energy Policy Act (EPACT): A 1992 federal law that created a more competitive marketplace for electricity generation by opening access to transmission networks and exempting some non-utilities from certain regulatory requirements, allowing their participation in wholesale electric power sales.

Exempt Wholesale Generator (EWG): An unregulated energy producer, not classified as a utility, that can generate electricity for sale at wholesale rates and purchase power for resale at market rates, but cannot sell electricity in the retail market.

Exit fee: A fee or tariff imposed on a customer that will no longer be supporting the payoff of the electricity supplier's sunk or stranded cost in generation equipment.

Federal Register (FR): A daily publication of the federal government that contains, among other things, proposed and final rules issued by the EPA.

Flue gas desulfurization (FGD): A postcombustion emission control technique for removing sulfur dioxide from flue gas. Wet scrubbers, dry scrubbers, and sorbent injection represent different FGD techniques.

Flue gas recirculation (FGR): The process of injecting flue gas into a boiler along with fresh combustion air to modify conditions within the combustion zone. The result of FGR is control of nitrogen oxide formation by lowering the peak flame temperature and reducing the oxygen concentration.

Forced-internal recirculation (FIR): A type of burner that uses a combination of premixing, staging, and interstage heat removal to control nitrogen oxide and carbon monoxide formation during combustion of natural gas. (Caution: Forced-internal recirculation should not be confused with fuelinduced recirculation, which is also represented by the acronym FIR.)

Fuel-induced recirculation (FIR): A nitrogen oxide reduction technique applicable to boilers that burn gaseous fuel. Fuel-induced recirculation is similar to flue gas desulfurization except that a portion of the flue gas is mixed with the fuel instead of combustion air. The effect of this mixture on the combustion process is to reduce the peak flame temperature. (Caution: Fuel-induced recirculation should not be confused with forced-internal recirculation, which is also represented by the acronym FIR.)

Gas turbine: A rotating machine that converts the chemical energy of fuel into mechanical energy. Basic elements of a gas turbine are the compressor, combustion chamber, and turbine. In operation, fresh air is drawn in by the compressor and forced into the combustion chamber. Inside the combustion chamber, the compressed air mixes with the fuel, and combustion occurs. During combustion, the chemical energy in the fuel is released to produce high-temperature combustion products that expand through the turbine and cause rotation.

Hazardous air pollutant (HAP): A category of air pollutants that is not covered by ambient air quality standards but which, as defined in the Clean Air Act, may reasonably be expected to cause or contribute to irreversible illness or death. There are 188 chemical compounds considered by the Environmental Protection Agency to be HAPs.

Heat exchanger: An unfired heat-recovery device that is capable of transferring heat from gas-togas, gas-to-liquid, liquid-to-gas, or liquid-to-liquid.

Heat-recovery muffler: An unfired heat-recovery device that recovers heat from reciprocating engine exhaust and uses the heat to generate hot water or steam.

Heat-recovery steam generator (HRSG): An unfired or supplementary fired heat exchanger that uses thermal energy to produce hot water or steam. The main application for unfired HRSGs is waste heat recovery and steam production from gas turbine exhaust. Supplementary fired HRSGs for gas turbine applications include gas-fired or oil-fired burners that augment the steam or hot water generating capacity of the exhaust gas stream.

Higher heating value (HHV): The standard measure of the energy released during combustion of a fuel, assuming the product water is in the liquid state. For natural gas fuel, the HHV is approximately $10 \%$ higher than the lower heating value (LHV). 
ICI boiler: A fired heat-recovery device for industrial, commercial, and institutional facilities that uses the chemical energy in fuel to raise the energy content of water so that it can be used for heating and power applications.

Inverter: An electrical device that converts direct current power to alternating current power. Most inverters operate by cutting the direct current power into a series of blocks or square waves at a number of different frequencies. These blocks are then electrically summed to create a voltage wave form that approximates the required alternating current.

Isentropic efficiency: A comparison of the actual work output of a machine compared to the ideal, or isentropic, output. It is a measure of the effectiveness of extracting work from the expansion process and is used to determine the outlet conditions of the steam from a steam turbine.

Islanding: A safety hazard that can occur when a generating facility such as a CHP system continues to supply power to a portion of the electrical grid after the balance of the grid has been de-energized.

Isolated design and operation: An operating mode in which the CHP system is sized to meet the site peak with reserve allowance for short-term power transients and to operate with no connection to the electrical grid. By operating in this mode, no electricity purchases are required.

Lead $(\mathbf{P b})$ : A heavy metal that is one of the six criteria pollutants for which the EPA has established National Ambient Air Quality Standards. Lead emissions result from the combustion of leaded gasoline (being phased out), use of certain paints (houses, cars), operation of smelters (metal refineries), and manufacture of lead-acid storage batteries. Combustion boilers are not a major source of lead emissions.

Load-tracking: An operating mode for a CHP system that is designed to track either the site's thermal or electric load. By operating in this mode, supplemental power purchases, heat rejection, or supplemental thermal energy may be required, but both electric and thermal approaches can be designed to supply the site's peak requirements.

Low excess air (LEA): A boiler operating condition in which the lowest possible excess air level is provided while maintaining good combustion. Operating with LEA creates conditions within the combustion zone that lower nitrogen oxide production.

Lower heating value (LHV): The standard measure of the energy released during combustion of a fuel, assuming the product water is in the gaseous state. For natural gas fuel, the LHV is approximately $10 \%$ lower than the higher heating value (HHV).

Lowest Achievable Emission Rate (LAER): The rate of emissions that reflects (1) the most stringent emission limitation contained in the implementation plan of any state for such source unless the owner or operator of the proposed source demonstrates that such limitations are not achievable or (2) the most stringent emission limitation achieved in practice by other sources within the same category. Application of this term does not permit a proposed new or modified source to emit pollutants in excess of existing New Source Performance Standards.

Low-NO $\mathbf{x}$ burner (LNB): A specially designed piece of combustion equipment that reduces nitrogen oxide formation through careful control of the fuel-air mixture during combustion. By proper staging of fuel and air, nitrogen oxide formation is controlled due to a lower maximum flame temperature and a reduced oxygen concentration.

Major modification: A modification with respect to Prevention of Significant Deterioration and New Source Review under the Clean Air Act.

Major stationary sources: A term used to establish the applicability of Prevention of Significant Deterioration and New Source Review regulations. In a nonattainment area, any stationary source that has a potential to emit more than 100 tons/year is considered a major stationary source. In attainment areas, the cutoff level may be either 100 or 250 tons/year, depending upon the type of source.

Maximum Achievable Control Technology (MACT): Emission limitations based on the best demonstrated control technology or practices in similar sources to be applied to major sources emitting one or more of the listed HAPs. 
Microturbine: A small gas turbine consisting of a compressor and a turbine. An internal heat exchanger known as a recuperator is often added to recover heat from the exhaust gases and thereby improve overall energy efficiency. In operation, a radial flow (centrifugal) compressor compresses the combustion air that is then preheated in the recuperator using heat recovered from the exhaust gas stream. After the heated air from the recuperator mixes with fuel in the combustion chamber, the hot combustion gases expand through the turbine and cause rotation.

MMBtu: A unit of measure for heat (million British thermal units).

Molten carbonate fuel cell (MCFC): A type of fuel cell that operates at higher temperature and is more efficient than the commercially available phosphoric acid fuel cell. The high exhaust temperature of a MCFC can generate additional electricity in a steam turbine or in a gas turbine combined-cycle CHP system. The MCFC is expected to target 1-20 MW stationary power applications and should be well suited for industrial CHP applications.

Municipal solid waste (MSW): A solid fuel consisting of a mixture of paper, wood, yard waste, food wastes, plastics, leather, rubber, and other noncombustible materials such as metal, glass, and rock, that are usually removed prior to combustion.

National Ambient Air Quality Standards (NAAQS): Uniform air quality standards established by the EPA that apply to outside air throughout the country. (See criteria pollutants.)

National Emissions Standards for Hazardous Air Pollutants (NESHAP): Emission standards set by the EPA for air pollutants, not covered by National Ambient Air Quality Standards, that may cause an increase in deaths or in a serious illness. Primary standards are designed to protect human health; secondary standards are designed to protect public welfare.

Natural gas reburning (NGR): A combustion modification technique for reducing emissions of nitrogen oxides by staging fuel rather than combustion air. In this technique, a portion of the fuel is injected downstream of the main combustion zone. The result is reduced formation of nitrogen oxides through lower peak flame temperatures and reduced oxygen concentrations.

New Source Performance Standards (NSPS): Uniform national air emissions requirements that limit the amount of pollution allowed from specific new sources or from existing sources that have been modified.

New Source Review (NSR): A Clean Air Act requirement that State Implementation Plans must include a permit review that applies to the construction and operation of new and modified stationary sources in nonattainment areas to ensure attainment of National Ambient Air Quality Standards.

New source: Any stationary source that is built or modified after publication of final or proposed regulations that prescribe a standard of performance that is intended to apply to that type of emission source.

Nitrogen oxides $\left(\mathrm{NO}_{\mathbf{x}}\right)$ : The cumulative emissions of nitric oxide $(\mathrm{NO})$, nitrogen dioxide $\left(\mathrm{NO}_{2}\right)$, and other trace compounds of nitrogen produced when fuel is burned. Nitrogen dioxide is one of the six criteria pollutants for which the Environmental Protection Agency has established National Ambient Air Quality Standards.

Nonattainment area (NAA): A geographic area that does not meet one or more of the National Ambient Air Quality Standards for the criteria pollutants designated in the Clean Air Act.

Overfire air (OFA): Combustion air that is injected into a boiler above the normal combustion zone. This approach is generally used in conjunction with operating the burners at a lower than normal air-tofuel ratio to reduce the formation of nitrogen oxides. When applied, OFA is supplied above the main combustion zone to achieve complete combustion. Overfire air is a feature often incorporated into lowNOx burner designs.

Oxygen trim (OT): A boiler operational modification that limits the amount of excess oxygen available for combustion. 
Ozone $\left(\mathbf{O}_{3}\right)$ : One of the six criteria pollutants for which the EPA has established National Ambient Air Quality Standards. Ground-level ozone is formed when vehicle exhaust and combustion emissions mix with certain other chemicals in the presence of strong sunlight.

Particulate matter (PM): One of the six criteria pollutants for which the EPA has established National Ambient Air Quality Standards. Particulate matter includes fine liquid or solid particles such as dust, smoke, mist, fumes, or smog found in air or emissions from combustion.

Parts per million (ppmV): A way of expressing concentrations of substances in air, water, soil, human tissue, food, or other products based on volume.

Peak load: The peak load is the maximum demand for heat or electricity that occurs in any one hour in a year.

Peak shaving: An operating mode for a CHP system that is designed to satisfy the site's peak power requirements either by operating during the site's peak demand periods or during the utility's peak demand periods. By operating in this mode, the purchase of more expensive on-peak power is avoided thereby decreasing the average price of power.

Phosphoric acid fuel cell (PAFC): A type of fuel cell that uses concentrated phosphoric acid as the electrolyte. The relative stability of concentrated phosphoric acid is high compared to other common acids; consequently, a PAFC is capable of operating at the high end of the acid temperature range (212 to $\left.428^{\circ} \mathrm{C}\right)$.

Plantwide applicability limitation (PAL): A voluntary limit or "cap" on a facility's total emissions that is established based on the facility's historical emissions. This limit provides flexibility for a facility to make modifications without triggering major New Source Review requirements as long as the emissions cap is not exceeded.

$\mathbf{P M}_{10}$ : Particulate matter such as soot, dust, smoke, fumes, and mist with an aerodynamic diameter less than or equal to a nominal $10 \mu \mathrm{m}$.

$\mathbf{P M}_{2.5}$ : Particulate matter such as soot, dust, smoke, fumes, and mist with an aerodynamic diameter less than or equal to a nominal $2.5 \mu \mathrm{m}$.

Pollution control project (PCP): A project that results in significant emissions increases, but is exempt from New Source Review due to decreases in emissions of another pollutant.

Potential to emit (PTE): The rate of emission of an air contaminant of a process or process equipment while being operating at its maximum rated capacity. Certain physical or operational limits that are legally enforceable can affect the potential to emit.

Power quality: A relative term used to characterize electrical energy. Power quality is influenced by correcting the power factor to keep the voltage and current in phase, maintaining strict voltage levels, and minimizing harmonic distortions.

Power-to-heat ratio: An indication of the proportion of power (electrical or mechanical energy) to heat energy (steam or hot water) produced by a CHP system.

Prevention of Significant Deterioration (PSD): A regulatory program used to evaluate permits for new or modified sources in attainment areas. The intent is to prevent an attainment area from becoming a nonattainment area.

Proton exchange membrane fuel cell (PEMFC): A type of fuel cell that is of particular interest to the automotive industry as a future power plant for electric vehicles. The PEMFC has very high power densities and can start-up quickly and meet varying demand.

psig: A unit of pressure measurement (pounds per square inch gauge).

Public Utility Holding Company Act (PUHCA): Federal legislation of 1935 that prevents utility holding companies from subsidizing unregulated business activities from profits obtained from their regulated business activities and captive customers.

Public Utility Regulatory Policy Act (PURPA): A 1978 federal law that requires utilities to buy electric power from private "qualifying facilities," at an avoided cost rate. This avoided cost rate is equivalent to what it would have otherwise cost the utility to generate or purchase that power themselves. 
Utilities must further provide customers who choose to self-generate a reasonably priced backup supply of electricity.

Qualified Facility (QF): A utility is required under Section 210 of PURPA to purchase excess electricity generated by a qualified facility and to provide backup power at a reasonable cost. Qualified facilities included plants that use renewable resources or cogeneration technologies to produce electricity.

Reactive power: A measure of the amount of energy stored in an electrical circuit that performs no real work. The energy may be stored in magnetic fields of transformers and motors or in electromotive fields in capacitors. Reactive power, which is sometimes referred to as inductive power, is the product of the inductive current flowing through a load, and the voltage drop across the load is expressed in units of reactive kilovolt-amp (kVAR).

Real power: An indication of the amount of energy that performs real work. In simple resistive circuits, real power is defined as the product of the current flowing through the circuit and the voltage across that circuit. Real power is typically measured in units of kilowatt $(\mathrm{kW})$.

Reciprocating internal combustion engine (RICE): An internal combustion engine with a crankshaft that is turned by the movement of pistons inside cylinders.

Recuperator: A gas-to-gas heat exchanger designed to extract heat from an exhaust gas steam and use it to increase the temperature of incoming combustion air. Recuperators rely on tubes or plates to continuously transfer heat from the outgoing exhaust gas to the incoming combustion air. These components are arranged to keep the two gas streams from mixing.

Reducing air preheat (RAP): An emission control technique in which the temperature of preheated combustion air is lowered. Reducing the air preheat temperature can lower the peak flame temperature and result in reduced formation of nitrogen oxides.

Refuse-derived fuel (RDF): A solid fuel consisting of more than 50\% waste, including a mixture of paper, wood, yard waste, food wastes, plastics, leather, rubber, and other noncombustible materials such as metal, glass, and rock, which are usually removed prior to combustion.

Regenerator: A gas-to-gas heat exchanger in which heat is transferred indirectly as a heat storage medium is alternately exposed to hot and cold flow streams. Periodic exposure to hot and cold flow streams can be accomplished either by rotary or valve-switching devices. During operation, a small but significant amount of air leakage occurs from one gas stream to the other.

Selective catalytic reduction (SCR): A postcombustion emission control technique for reducing emissions of nitrogen oxides. In this technique, a catalyst and a reductant (ammonia gas) are used to dissociate nitrogen oxides to nitrogen gas and water vapor.

Selective discounting: A practice whereby an electrical supplier agrees to provide electricity to a customer at a reduced or discounted rate as an incentive to pursuing alternative electrical generating capability.

Selective noncatalytic reduction (SNCR): A postcombustion emission control technique for reducing emissions of nitrogen oxides. In this technique, a reducing agent of either ammonia or urea is used to dissociate nitrogen oxides to nitrogen gas and water vapor.

Small power producer (SPP): A small power production facility under PURPA that generates electricity using waste, renewable (water, wind, and solar), or geothermal energy as a primary energy source. Fossil fuels can be used by SPPs, but renewable resource must provide at least $75 \%$ of the total energy input.

Solid oxide fuel cell (SOFC): A type of fuel cell that offers the reliability of all solid ceramic construction and is expected to have an electric efficiency of up to 50\% (LHV). The high exhaust temperature of a SOFC can be used to generate additional electricity in a steam turbine or in a gas turbine combined-cycle CHP system.

Source: A term that applies to each point at which emissions are released or an entire facility where a pollutant is emitted. 
Spark ignition (SI) engine: A reciprocating internal combustion engine that uses an externally supplied spark to ignite a compressed mixture of fuel and air. (Caution: Spark ignition should not be confused with steam injection which is also represented by the acronym SI.)

Staged combustion air (SCA): An emission control technique in which air is injected into a boiler at different points or stages in the combustion process to reduce the peak flame temperature and lower the oxygen concentration, thereby controlling the formation of nitrogen oxides. Techniques based on this concept include BOOS, BF, OFA, and LNBs.

Staged combustion: A technique that involves mixing air and fuel at two or more locations inside a boiler to create zones with high and low excess air levels. Combustion at either very low or very high excess air levels results in reduced formation of nitrogen oxides.

Standard cubic foot (scf): A unit of measure for gas. One standard cubic foot of gas is the quantity of gas saturated with water vapor at a pressure of $30 \mathrm{in}$. of mercury at $60^{\circ} \mathrm{F}$ that occupies one cubic foot.

State Implementation Plan (SIP): A state plan approved by the EPA for establishment, regulation, and enforcement of air pollution standards.

Stationary source: A fixed, nonmoving producer of pollution, mainly power plants, manufacturing facilities, refineries, and other facilities that emit air pollutants.

Steam injection (SI): An emission control technique used to decrease the flame temperature and thereby reduce the formation of nitrogen oxides during combustion. (Caution: Steam injection should not be confused with spark ignition, which is also represented by the acronym SI.)

Steam turbine: A rotating machine that converts the kinetic energy of moving steam into mechanical energy. Steam turbines are constructed with a stationary set of blades (called nozzles) and a moving set of adjacent blades (called buckets or rotor blades) installed within a pressure-retaining housing. Stationary nozzles accelerate the steam to high velocity by expanding it to lower pressure while the rotating blades change the direction of the steam flow to produce torque. Steam turbines are subdivided into two principal turbine types, impulse and reaction, depending on the way they direct steam flow.

Sulfur dioxide $\left(\mathbf{S O}_{2}\right)$ : A pollutant that is often emitted during the combustion of sulfur-bearing fuels. Sulfur dioxide is one of the six criteria pollutants for which the EPA has established National Ambient Air Quality Standards.

Sulfur oxides $\left(\mathbf{S O}_{\mathbf{x}}\right)$ : Any of several oxides of sulfur.

Synchronizing: The process by which the sinusoidal output voltage waveform of an alternating current electrical generator is brought precisely into line with the frequency, time, and voltage of another electrical generator or with the main system to which it is to be connected.

Thermodynamic efficiency: A term used for expressing efficiency for devices that operate in cycles or for individual components that operate in processes.

Three-way catalyst (TWC): A postcombustion emission control device for spark ignition engines that uses ceramic substrates and trimetal catalyst formulations.

Tire-derived fuel (TDF): A solid fuel consisting of whole scrap tires in a chipped form.

Topping cycle: A heat-recovery scheme in which the energy in fuel is first used to generate electricity. Waste heat from the prime mover is then recovered and used for process heating or cooling applications.

Total CHP efficiency: A measure of the net electricity generated, the net heat supplied to the process, and the total fuel input expressed as follows:

(Net electricity generated + Net heat supplied to process)/Total fuel input

Toxic air pollutant: An air pollutant that is known or suspected to cause cancer or other serious health effects. There are 188 toxic air pollutants, also known as HAPs, regulated by the EPA.

Trigeneration: A combined-cycle CHP system that includes cooling equipment such as an absorption chiller. 
Uplift tariff: A fee or tariff charged to a CHP system owner or operator by the distribution utility for transmission of the CHP-produced electricity to the market. The uplift tariff could reflect costs for distribution, ancillary services, capacity, and losses.

Volatile organic compound (VOC): Any organic compound that participates in atmospheric photochemical reactions except those designated by the EPA Administrator as having negligible photochemical reactivity.

Waste heat-recovery boiler: An unfired heat-recovery device such as a heat-recovery steam generator that uses heat recovered from hot exhaust gases as fuel for generating hot water or steam.

Water injection (WI): An emission control technique used to decrease the peak flame temperature and thereby reduce the formation of nitrogen oxides during combustion. 
ORNL/TM-2004/144

\section{INTERNAL DISTRIBUTION}

$\begin{array}{llrl}\text { 1. } & \text { D. Cox } & 9 . & \text { K. L. McElhaney } \\ \text { 2. } & \text { R. C. DeVault } & 10-27 . & \text { C. B. Oland } \\ \text { 3. } \text { S. K. Fischer } & 28 . & \text { M. Olszewski } \\ \text { 4. } & \text { E. C. Fox } & 29 . & \text { C. C. Southmayd } \\ \text { 5. } & \text { P. W. Garland } & 30 . & \text { T. Theiss } \\ \text { 6. } & \text { C. R. Hudson } & 31-33 . & \text { A. L. Wright } \\ \text { 7. } & \text { D. K. Jamison } & 34 . & \text { ORNL Laboratory Records (OSTI) } \\ \text { 8. } & \text { R. E. Leach } & 35 . & \text { ORNL Laboratory Records (RC) }\end{array}$

\section{EXTERNAL DISTRIBUTION}

36-45. R. D. Bessette, President, Council of Industrial Boiler Owners, 6035 Burke Centre Parkway No. 360, Burke, VA 22015

46-48. R. Gemmer, U.S. Department of Energy, EE-2F, 1000 Independence Ave., SW, Washington, DC 20585-0121

49. G. Harrell, Ph.D., P.E., Senior Research Associate, The University of Tennessee Knoxville, Environmental and Resources Center, 311 Conference Center Building, Knoxville, TN 379964134

50. C. B. Hooper, Steam Solutions, Inc., 2220 Banstead Road, Midlothian, VA 23113

51. R. Jendrucko, University of Tennessee, Department of Mechanical and Aerospace Engineering, 301 Perkins Hall, Knoxville, TN 37996

52. J. S. Moore, TA Engineering, Inc., Catonsville Professional Center, 405 Frederick Road, Suite 252, Baltimore, MD 21228

53-55. R. N. Mosher, President, R. N. Mosher \& Associates, 3997 Gumwod Court, Chantilly, VA 20151-2601

56-65. W. R. Rawson, President, American Boiler Manufacturers Association, 4001 N. 9th St., Suite 226, Arlington, VA 22203-1900

66. M. Smith, U.S. Department of Energy, 1000 Independence Ave., SW, Washington, DC 205850121

67. G. Talmage, Pennsylvania State University, Department of Mechanical and Nuclear Engineering, 306 Reber Building, University Park, PA 16802

68. A. C. Thekdi, E3M, Inc., 15216 Gravenstein Way, North Potomac, MD 20878 